Hydrogeologic and

Hydrochemical Framework,

South-Central Great Basin,

Nevada-California, with Special

Reference to the Nevada Test Site

GEOLOGICAL SURVEY PROFESSIONAL PAPER 712-C

Prepared on behalf of the

U.S. Atomic Energy Commission

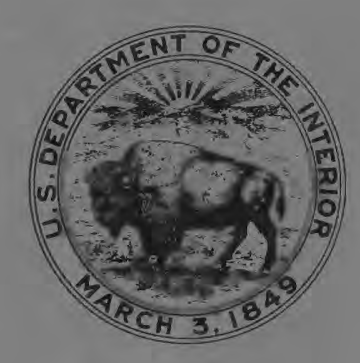



HYDROGEOLOGIC AND HYDROCHEMICAL FRAMEWORK, SOUTH-CENTRAL GREAT BASIN, NEVADA-CALIFORNIA, WITH SPECIAL REFERENCE TO THE NEVADA TEST SITE 


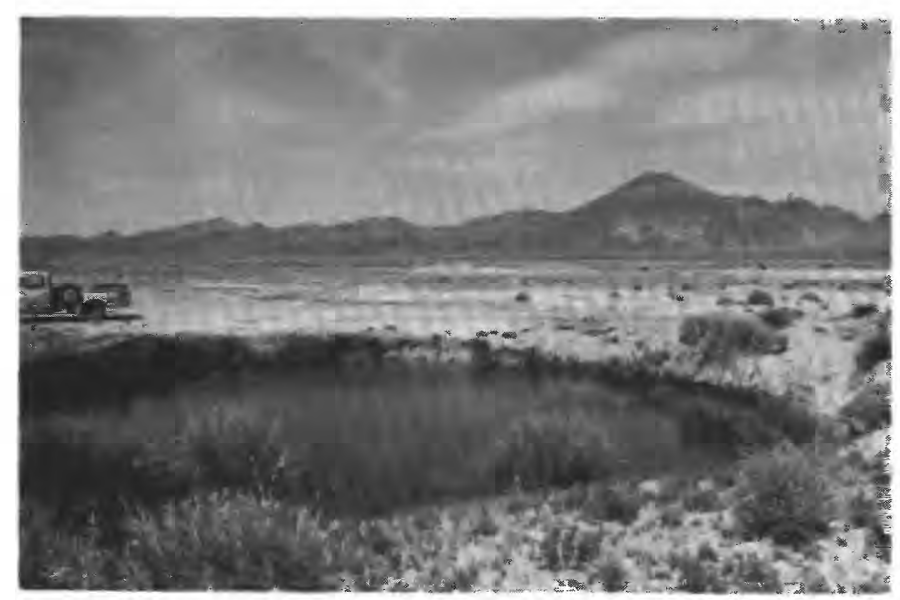

Big Spring, Ash Meadows, Nev. Spring emerges from lake beds. Discharge about 1,000 gallons per minute; water temperature $82^{\circ} \mathrm{F}$ $\left(28^{\circ} \mathrm{C}\right)$. Paleozoic carbonate and clastic rocks form hills east of spring.

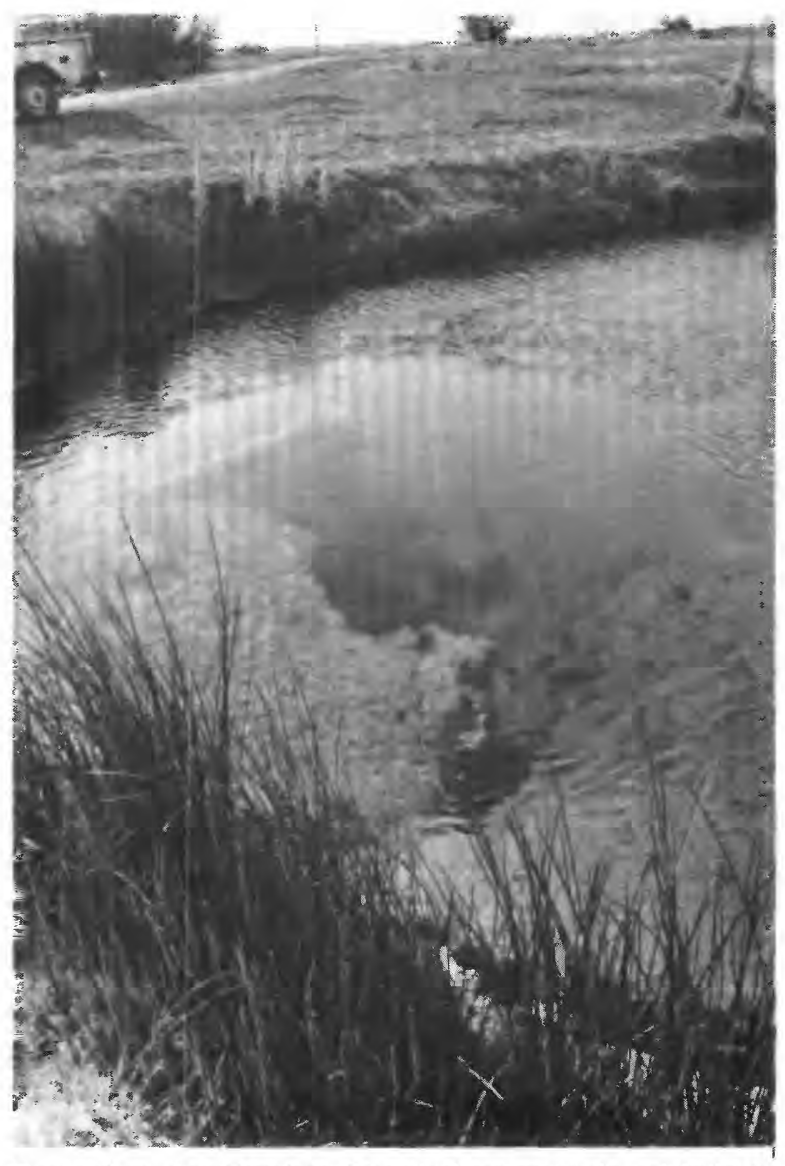

Crystal Pool, Ash Meadows, Nev. Spring emerges from lake beds. Orifice (center of photo) dips steeply northward (to left) beneath travertine(?) lip. Discharge, 2,800 gallons per minute, is largest of pool springs in the area; water temperature $88^{\circ} \mathrm{F}$ $\left(31^{\circ} \mathrm{C}\right)$. 
FIGURE 25. Semilog graphs of drawdown and residual drawdown of water level during pumping test in well 74-70b, September 9-11, 1959

Page

26. Semilog graph of recovery of water level during 133-day shutdown in well 74-70b, December 23, 1960, to May 4, 1961

27. Semilog graphs of drawdown and residual drawdown of water level during pumping test in well 74-70a, August 27-29, 1959

28. Semilog graphs of drawdown and residual drawdown of water level during pumping test in well 83-68, September 20-21, 1960

29. Semilog graph of residual drawdown of water level during pumping test in well $91-74$, November $23-25,1959$

30. Diagrammatic section showing perched and semiperched ground water in the tuff aquitard of Rainier Mesa

31. Map showing hydrogeology of Frenchman Flat _

32. Map and sections showing hydrogeology of Emigrant Valley

33. Map and sections showing hydrogeology of southern Indian Springs Valley

34. Map showing hydrogeology of southeastern Amargosa Desert _

35. Map and graph showing major springs at Ash Meadows _

36. Photograph showing solution notches marking water levels as much as 4 feet above 1966 water level of pool at Devils Hole

37. Photograph showing possible former stand of water about 20 feet above 1966 water level on south wall of Devils Hole

38. Trilinear diagram showing chemical types of the ground water at Nevada Test Site and vicinity _._.

39. Graph showing regional variations in $\mathrm{Na}+\mathrm{K}$ and $\mathrm{Ca}+\mathrm{Mg}$ within the lower carbonate aquifer

40. Graph showing regional variations in $\mathrm{Na}+\mathrm{K}, \mathrm{HCO}_{3}+\mathrm{CO}_{3}$, and $\mathrm{SO}_{4}+\mathrm{Cl}$ within the lower carbonate aquifer C38

\section{TABLES}

1. Stratigraphic and hydrogeologic units at Nevada Test Site and vicinity

3. Pumping-test data for aquifers in Nevada Test Site and vicinity

4. Interstitial porosity and permeability of cores from the lower clastic aquitard, well $89-68$, Yucca Flat

5. Interstitial porosity and permeability of cores from the tuff aquitard, Nevada Test Site

6. Hydraulic gradients in Cenozoic hydrogeologic units, Yucca Flat

7. Spring discharge at Ash Meadows in 1953 and 1962

8. Chemical constituents of ground water in the Nevada Test Site and vicinity

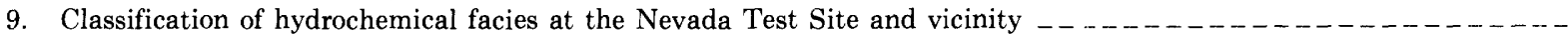

10. Chemical analyses of water from test wells 89-68 and 67-68, Yucca Flat and Mercury Valley, Nye County _......

11. Chemical analysis of water from test well 68-69, Mercury Valley, Nye County _...

12. Chemical analyses of water from three depth intervals in test well 73-66, Rock Valley, Nye County _.......

13. Summary of deuterium content of water from major springs, southern Great Basin, Nevada-California

14. Estimated ground-water velocity in tuff aquitard, Yucca Flat, Nye County

15. Estimated ground-water velocity in lower carbonate aquifer beneath central Yucca Flat and Specter Range, Nye county 


\title{
HYDROGEOLOGIC AND HYDROCHEMICAL FRAMEWORK, SOUTH- CENTRAL GREAT BASIN, NEVADA-CALIFORNIA; WITH SPECIAL REFERENCE TO THE NEVADA TEST SITE
}

\author{
By IsaAC J. Winograd and William Thordarson
}

\begin{abstract}
Intensely fractured Precambrian and Paleozoic carbonate and clastic rocks and block-faulted Cenozoic volcanic and sedimentary strata in the Nevada Test Site are divided into 10 hydrogeologic units. Three of these - the lower clastic aquitard, the lower carbonate aquifer, and the tuff aquitard - control the regional movement of ground water. The coefficients of fracture transmissibility of these rocks are, respectively, less than $1,000,1,000$ to 900,000 , and less than 200 gallons per day per foot; interstitial permeability is negligible. Solution caverns are locally present in the carbonate aquifer, but regional movement of water is controlled by variations in fracture transmissibility and by structural juxtaposition of the aquifer and the lower clastic aquitard. Water circulates freely to depths of at least 1,500 feet beneath the top of the aquifer and up to 4,200 feet below land surface.

Synthesis of hydrogeologic, hydrochemical, and isotopic data suggests that an area of at least 4,500 square miles (including 10 intermontane valleys) is hydraulically integrated into one ground-water basin, the Ash Meadows basin, by interbasin movement of ground water through the widespread carbonate aquifer. Discharge from this basin - a minimum of about 17,000 acre-feet annually - occurs along a fault-controlled spring line at Ash Meadows in east-central Amargosa Desert.

Intrabasin movement of water between Cenozoic aquifers and the lower carbonate aquifer is controlled by the tuff aquitard, the basal Cenozoic hydrogeologic unit. Such movement significantly influences the chemistry of water in the carbonate aquifer.

Ground-water velocity through the tuff aquitard in Yucca Flat is less than 1 foot per year. Velocity through the lower carbonate aquifer ranges from an estimated 0.02 to 200 feet per day, depending upon geographic position within the flow system. Within the Nevada Test Site, ground water moves southward and southwestward toward Ash Meadows.
\end{abstract}

\section{INTRODUCTION}

In 1957, the U.S. Atomic Energy Commission detonated the first of a series of underground nuclear explosions at Nevada Test Site. Underground testing was started to prevent atmospheric fallout, a by-product of earlier series of surface and aerial detonations at the Test Site. Since 1957, the U.S. Atomic Energy Commission has detonated many nuclear devices in a variety of underground geologic and hydrologic environments. Although such testing minimizes contamination by atmospheric fallout, data for evaluating the possible contamination of ground-water reservoirs in the vicinity of these detonations were lacking in 1957. Yet, the sole source of water at Nevada Test Site and vicinity was from wells and springs.

To fulfill its obligation toward public safety, to prevent, if possible, even local contamination of a valuable natural resource, and to defend itself against possible damage claims, the U.S. Atomic Energy Commission in 1957 asked the U.S. Geological Survey to study the occurrence and the movement of ground water beneath the Nevada Test Site. Specifically sought was an evaluation of the potential for contamination of ground water in and near the Test Site.

\section{PURPOSE AND SCOPE}

The purposes of this investigation were to (1) define the hydraulic character and subsurface distribution of the major aquifers and aquitards, (2) identify and describe the principal areas of recharge to and discharge from the major aquifers, and (3) determine the rate and the direction of ground-water movement within the major aquifers and aquitards. Of these objectives, the third was of prime importance for an evaluation of the rate of movement of various radionuclides from the vicinity of an underground nuclear detonation. The accuracy of the velocity estimates, however, rested heavily upon the other two study objectives.

The Nevada Test Site occupies a small part of two ground-water basins - the Ash Meadows and the Oasis Valley-Fortymile Canyon basins. Consequently, the objectives are discussed for a region several times the size of the test site. 
The scope of the report is broad in view of the complexities of the geology, the vastness of the study area, and the absence of previous detailed hydrogeologic studies of similar terrane. Yet, the types and quantity of data obtained during this investigation are seldom available in hydrogeologic studies. In addition to standard hydrologic data, a wealth of geologic, geophysical, geochemical, and isotopic data were used to supplement interpretations of the hydrologic data. To a first approximation, therefore, the objectives of the study are believed to have been accomplished.

The development of ground-water supplies was an important byproduct of the investigation; more than half the test holes are used as water wells. This report does not discuss the exploration for, and development of, new water supplies, although many of the data and interpretations will aid others in such tasks.

\section{HISTORY OF THE INVESTIGATION AND PREVIOUS REPORTS}

Hydrologic data for this report were collected and interpretations were made over an 8-year period, 1957-64. The work was done in three phases: (1) the period 1957-59, (2) the period 1960-61, corresponding in part with the moratorium on both surface and underground nuclear testing, a ban in effect from November 1958 through September 1961; and (3) the period 1962-64, coinciding with the renewed nuclear testing at Nevada Test Site.

The initial phase of the study was devoted to two major tasks. First, hydrologic data were collected from all existing wells and springs at and in the vicinity of Nevada Test Site. Second, the hydrology of tuff underlying Rainier Mesa was studied in detail in more than 5 miles of tunnels, drifts, and shafts driven into the east face of that mesa. This phase of the work, done under the direction of Mr. Alfred Clebsch, Jr., resulted in several reports. Clebsch and Winograd (1959) evaluated the regional hydrology of the test site area, and J. E. Moore (1961 and 1962) and Clebsch and Barker (1960) tabulated data on most existing wells and springs of the area. Hood (1961) analyzed pumping tests of four wells, and Clebsch (1961) analyzed the significance of tritiumage measurements of ground water from supply wells and springs. Thordarson (1965) described the hydrology of Rainier Mesa, and Clebsch (1959 and 1960) evaluated potential water-supply contamination from the underground nuclear testing beneath Rainier Mesa. Schoff and Winograd (1961 and 1962) described the hydraulic data obtained from six core holes drilled into carbonate rocks in northern Yucca Flat.

The second phase of the program (1960-61) was principally a study of the hydrology of Yucca Flat. It was prompted by the U.S. Atomic Energy Commission's plan to utilize Yucca Flat as an underground testing area if nuclear testing were resumed. To acquire an un- derstanding of the hydrology and subsurface geology of the valley, six test holes ranging in depth from 1,700 to 2,300 feet were drilled in Yucca Flat. Before the drilling, gravity and some seismic surveys were made to aid in selection of the drill sites. The geology of the ridges surrounding the valley was mapped concurrently with the drilling. Mapping provided stratigraphic and structural background for interpretation of the stratigraphic sequence penetrated by the drill holes.

Test drilling, begun in April 1960 and completed in September 1961, was under the general supervision of Mr. Stuart L. Schoff and under the field direction of $\mathrm{Mr}$. I. J. Winograd. The lithologic, hydrologic, and physicalproperty data obtained from five of these holes were summarized by Price and Thordarson (1961), Thordarson, Garber, and Walker (1962), Garber and Thordarson (1962), J. E. Moore and Garber (1962), and J. E. Moore, Doyle, Walker, and Young (1963). A brief synthesis of the test-hole data, emphasizing how the data related to the regional flow of ground water, was presented by Winograd (1962).

In September 1961, soon after completion of the test drilling in Yucca Flat, the moratorium on the testing of nuclear weapons ended. The U.S. Atomic Energy Commission immediately requested new test areas that would permit testing at greater depths. To meet this request, the U.S. Geological Survey expanded its hydrologic, geologic, and geophysical studies to encompass unexplored areas of the Nevada Test Site. Contamination of ground water through underground testing in the Cenozoic strata in Yucca Flat was considered only a slight possibility. Independent studies by geochemists of the U.S. Geological Survey and the Lawrence Radiation Laboratory showed that ion-exchange capacity of the Cenozoic strata at depths of proposed underground testing would probably prevent most radionuclides from moving more than a few hundred to a few thousand feet from the point of detonation. Moreover, much of the Cenozoic tuff to be used as a host for most of the events was an aquitard of extremely low transmissibility. However, the quest for deeper sites and the suggestion that the widespread Paleozoic carbonate rocks are highly transmissive dictated that further studies be made of those deeper aquifers.

To provide a more complete understanding of the regional flow of ground water within the Paleozoic carbonate rocks, the U.S. Geological Survey began a second drilling program early in 1962 and completed it by mid1963. Ten test holes, ranging in depth from 900 to 5,500 feet were drilled. Eight of the holes tested the Paleozoic strata. Only 2 of the 10 holes were drilled in Yucca Flat; the others were drilled in Indian Springs Valley, Frenchman Flat, and Jackass Flats. To obtain stratigraphic information or a water supply, Los Alamos Scientific Laboratory, Lawrence Radiation Laboratory, 
and Reynolds Electrical and Engineering Co. drilled several dozen additional test holes in Yucca Flat. In the 10 holes drilled specifically for hydrologic information, a wide variety of hydrologic, geologic, and physicalproperty data were obtained from each aquifer penetrated. But in some of the stratigraphic test holes, drilling methods and time considerations precluded even a determination of the static water level in the principal aquifer.

The third phase of the work, devoted to collection of data from the various test holes drilled from 1962 to 1964, began under the general supervision of Mr. Stuart L. Schoff. Mr. William E. Hale succeeded Schoff as general supervisor. Mr. Isaac J. Winograd and $\mathrm{Mr}$. Richard A. Young directed the field efforts at Mercury, Nev.

Several reports describe the third phase of the study. Schoff and J. E. Moore (1964) discussed the chemistry of ground water at the Nevada Test Site and demonstrated how water-quality data might be utilized as an independent tool for determining the direction of ground-water movement. Winograd's (1963) review of the hydrology of the area between Las Vegas and the Amargosa Desert emphasized the development of a new water supply in southern Indian Springs Valley. Walker and Eakin (1963) made a reconnaissance of the Ash Meadows-Amargosa Desert discharge area, and Eakin, Schoff, and Cohen (1963) made a reconnaissance of the valleys surrounding the test site. Winograd and Eakin (1965) and Eakin and Winograd (1965) summarized the regional significance of the subsurface data from the holes penetrating the Paleozoic carbonate rocks. Winograd and Thordarson (1968) described structural control of ground-water movement within the carbonate rocks. The availability of construction data, lithologic and geophysical logs, water analyses, cores and cuttings yield and production records, and water levels for all the wells and test holes discussed in this report has been summarized by Thordarson, Young, and Winograd (1967).

Some of the subject matter of this present report has been described briefly in several of the reports previously listed. The present report, however, presents the first detailed analysis and synthesis of the hydrologic data collected during the second and third phases of the Survey's work at the test site. In addition, it integrates, for the first time, appropriate facets of the geologic and geophysical studies made concurrently with and in partial support of the hydrologic study program. The geologic data, in particular, were very useful in the evaluation of regional flow patterns.

\section{ACKNOWLEDGMENTS}

This report depends on the work of many people and organizations. First, we thank the U.S. Atomic Energy
Commission, Nevada Operations Office, for its support of the U.S. Geological Survey's studies at the Nevada Test Site. Particularly acknowledged are Messrs. O. H. Roehlk, R. L. Kinnaman, and R. T. Russell of the Operational Safety Division.

Of the 15 men who helped collect the subsurface data that form the backbone of this report, particular acknowledgment goes to Messrs. C. E. Price, R. F. Norvitch, M. S. Garber, and R. A. Young. Mr. C. E. Price prepared a series of geologic, hydrologic, and drilling checklists that were utilized throughout both drilling programs and were a great help in standardization of data collection. Mr. R. F. Norvitch supervised the pumping tests on half the test holes. In addition, he analyzed the step-drawdown tests in four of those wells. Mr. M. S. Garber, assisted by Mr. A. C. Doyle, mudified and calibrated existing instruments for accurate measurement of water levels at depths to 2,800 feet below land surface. Mr. R. A. Young supervised the drilling operations and, in Winograd's absence, served as acting field party chief.

Throughout the field effort and to a lesser degree during the report-preparation phase, the authors benefited greatly through technical discussions with many individuals in the U.S. Geological Survey. The specific contributions of these colleagues are acknowledged in the body of the text. Here we only briefly list the general area of help offered by them. Mr. W. E. Hale raised provocative questions throughout the period 1962 to 1965. His intense interest in the work led to a significant improvement in many facets of the field efforts. Mr. W. A. Beetem suggested utilization of chemical data as a tool in deciphering the regional flow system, and he and his associates collected and analyzed most of the water samples from which such an analysis was eventually made. Messrs. S. W. West, S. L. Schoff, Alfred Clebsch, Jr., G. F. Worts, Jr., and O. J. Loeltz offered continued technical advice and personal encouragement to the authors. The authors benefited greatly from numerous discussions of the regional geology and geophysics with many colleagues; they especially thank Messrs. R. L. Christiansen, Harley Barnes, and F. G. Poole. Thanks also go to Messrs. F. A. McKeown, P. P. Orkild, F. N. Houser, D. L. Healey, and E. B. Ekren for their interest and helpful discussions. The editorial assistance of Virginia Glanzman and Billy Robinson is gratefully acknowledged.

Numerous individuals working for the prime contractor, the testing laboratories, and other firms were a constant source of help, including Messrs. R. W. Newman, Willard Martin, Leonard Palmer, Emmett Herbst, Robert R. Gunny, Ross McDonald, and Merv Boggs.

\section{WELL-NUMBERING SYSTEM}

Wells and test holes referred to in this report are iden- 
tified by the Nevada coordinate system, central zone, or by township, range, and section. All the holes within or in the immediate vicinity of Nevada Test Site are identified by the 10,000-foot grid of the Nevada coordinate system, central zone, the system used by the U.S. Atomic Energy Commission and its contractors. The first two digits of the north coordinate and the first two digits of the east coordinate of this grid are used to identify the well. Thus, a well at coordinates N. 671,051 feet and E. 739,075 feet is identified by the numbers $67-73$. Where more than one well is in the same 10,000-foot grid, one hole will be designated by four numbers, and all others by consecutive letters after the fourth number for example, 67-73, 67-73a, and 67-73b. The alphabetical designation does not necessarily indicate the sequence in which the holes were drilled.

Wells in the Amargosa Desert, in Pahrump Valley, and elsewhere along the periphery of the study area are identified by township, range, and section. In the part of the study area in Nevada, the townships with a few exceptions are south of the Mount Diablo base line; the ranges are all east of the Mount Diablo meridian. Therefore, these geographic designations are not given in the well designation. For example, a well in the $\mathrm{NW}^{1 / 4}$ sec. 27 , T. 16 S., R. 51 E., is identified simply by 16/51-27b. The letters a, b, c, or d, which follow the section number, refer respectively to the northeast, northwest, southwest, and southeast quarter sections. Double letters that follow a section number identify a well site in a 40 -acre tract. Thus the well number for location $\mathrm{SW}^{1 / 4} \mathrm{NE}^{1 / 4}$ sec. 34, T. 19 S., R. 53 E., is 19/53-34ac. A number after the letter was used by Walker and Eakin (1963) in the Amargosa Desert to designate the number of wells in a quarter section. Wells in California are readily identified by a capital $\mathrm{N}$ that follows the township designation. In California, the townships are north and the ranges east of the San Bernardino base line and meridian, respectively.

\section{GEOGRAPHIC SETTING}

The study area generally lies within the area bounded by lat $36^{\circ} 20^{\prime}$ and $37^{\circ} 30^{\prime} \mathrm{N}$. and long $115^{\circ} 10^{\prime}$ and $116^{\circ} 45^{\prime}$ W. (fig. 1). It encompasses about 7,100 square miles of Clark, Lincoln, and Nye Counties, Nev., and Inyo County, Calif. This area is within the south-central part of the Great Basin section of the Basin and Range physiographic province defined by Fenneman (1931). Some botanists consider the region a part of the Mohave Desert (Jaeger, 1957). The Nevada Test Site, an area of about 1,400 square miles (all in Nye County) in the central part of this region, is the area of detailed study.

\section{PHYSIOGRAPHY}

In the region are two of the largest valleys in southeastern and south-central Nevada and two of the highest mountain ranges. The Las Vegas Valley, bordering the study area on the southeast (fig. 1), is about 40 miles long and as much as 20 miles wide; the valley trends south-southeast, and its floor ranges in altitude from 2,000 to 3,000 feet. The Amargosa Desert, a valley that forms the southwestern part of the study area, is approximately 50 miles long and as much as 20 miles wide. This valley also trends southeast, and its floor generally ranges in altitude from 2,000 to 3,000 feet. The eastcentral part of Death Valley, one of the largest intermontane valleys of the Great Basin, lies in the southwest corner of the study area (fig. 1).

Smaller intermontane valleys within the study area include, from east to west, Pahranagat Valley, Desert Valley (also called Tikaboo Valley), Three Lakes Valley, Indian Springs Valley, Emigrant Valley, Frenchman Flat, Yucca Flat, Pahrump Valley, and Jackass Flats. The floors of these north-nort west trending basins range in altitude from 3,000 to 4,500 feet.

The two predominant mountain ranges are the Spring Mountains, bordering the study area on the south, and the Sheep Range, forming the eastern border (fig. 1). The Spring Mountains trend northwest, are about 45 miles long, and are up to 18 miles wide. These mountains, which merge with the flanking bajadas at altitudes ranging from 5,000 to 6,000 feet, reach an altitude of nearly 12,000 feet.

The Sheep Range trends north, is about 45 miles long, and is as much as 8 miles wide. The maximum altitude of the Sheep Range is nearly 10,000 feet.

The northern third of the study area includes, from east to west, the Pahranagat, Timpahute, Groom, and Belted Ranges, and Pahute Mesa. These four ranges trend northward and range in altitude from 6,000 to 9,000 feet. Pahute Mesa ranges in altitude from 5,000 to 7,000 feet. These uplands, although small in comparison with the imposing Spring Mountains and Sheep Range, are nevertheless prominent features in comparison with the numerous ridges and mesas lying within the central part of the region. The centrally located ridges and mesas are generally less than 6,000 feet high.

The area is a superb example of Great Basin topography. The contrast in slope between the valley floors and the flanking ridges is generally striking even where the relief between them is small. Most of the basins contain playas, and some contain badlands developed on exhumed pluvial lakebeds. Pediments, which are characteristic of some intermontane basins, are usually absent; where present, the pediments are disrupted by normal faults.

Las Vegas and Pahranagat Valleys are tributary to the Colorado River. Jackass Flats and the Amargosa Desert are connected to Death Valley via the Amargosa River (fig. 1). Drainage in most of the remaining valleys within the study area is to playas. 


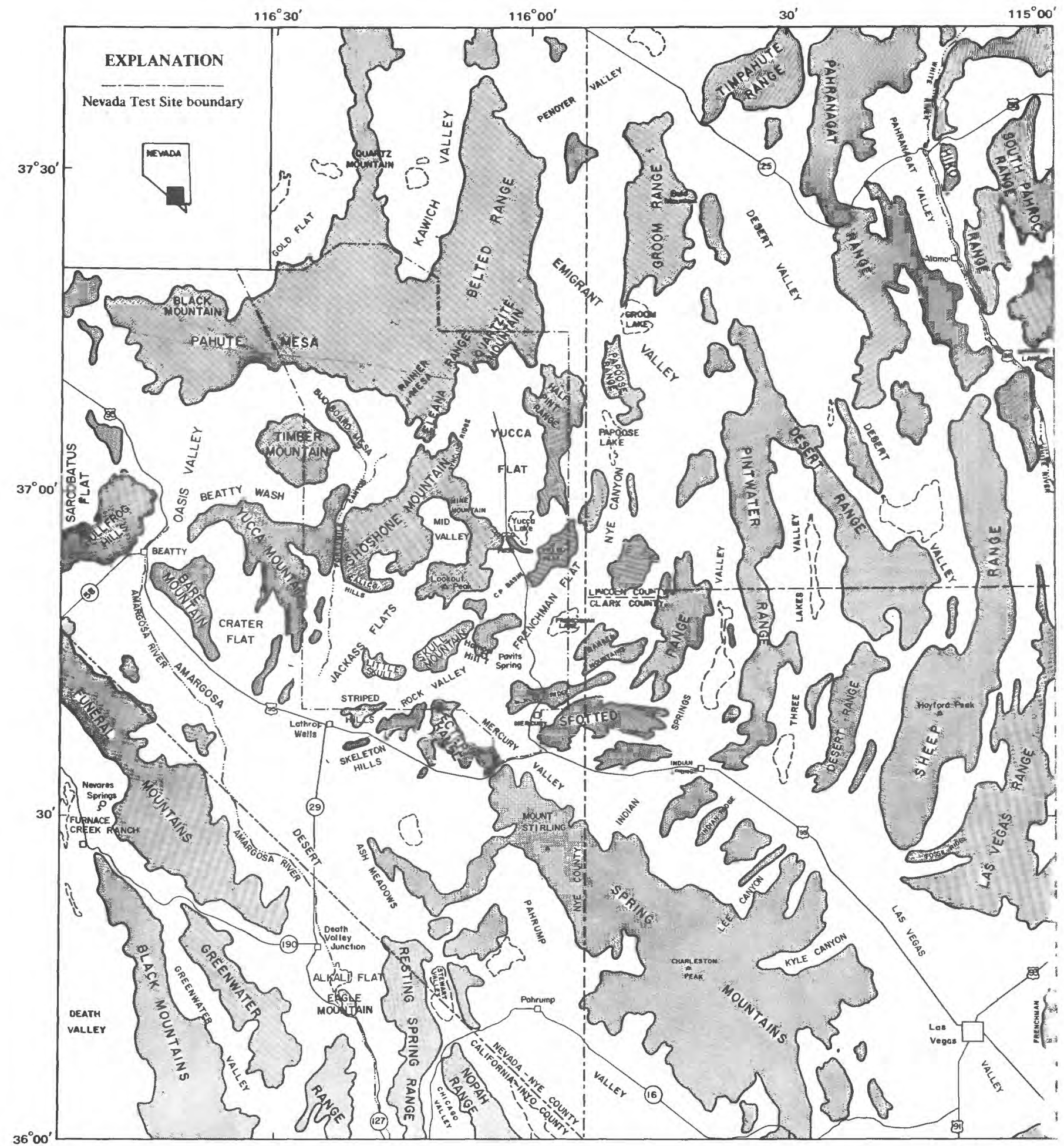

$\underbrace{0}_{0} \underbrace{10}_{10} \underbrace{10}_{20} \underbrace{20}_{30 \text { KILOMETERS }} 30$ MILES

FIGURE 1. - Index map of Nevada Test Site and vicinity. 
No large perennial or intermittent streams are found in the region. Several of the prominent perennial springs near the base of the Spring Mountains periodically flow a few thousand feet to 1 mile or so from their orifices before being diverted or seeping into alluvial fans. The Amargosa River may be intermittent in a short reach in the vicinity of Beatty, Nev.

\section{ECONOMIC DEVELOPMENT}

One major and three minor population centers are within or immediately adjacent to the study area. The city of Las Vegas and its suburbs are the major center, having a population of about 240,000 people (Nevada Chamber of Commerce, 1965). The minor population centers are Indian Springs in Clark County and Mercury and Beatty in Nye County. The 1965 population of these villages was about $2,000,1,200$ and 500 people, respectively. The population of these small communities fluctuates with the level of activity at the Nevada Test Site. Tourism is the major industry in Las Vegas and at Beatty, but a sizeable part of the income in both communities comes from expenditures of the U.S. Atomic Energy Commission and the National Aeronautics and Space Administration at the Nevada Test Site, and of the U.S. Air Force at Nellis Air Force Base north of Las Vegas.

Except for several thousand acre-feet of water piped into Las Vegas from Lake Mead, ground water was the sole source of water for the entire region of study in 1967. The pumpage for the city of Las Vegas amounted to about 42,000 acre-feet in 1964 .

\section{Climate}

The study area lies principally within the most arid part of Nevada, the most arid State in the Union. The average annual precipitation on the valleys ranges from 3 to 6 inches and on most of the ridges and mesas averages less than 10 inches. The potential annual evaporation from lake and reservoir surfaces was estimated by Meyers (1962) to range from 60 to 82 inches, or roughly 5 to 25 times the annual precipitation. The diurnal relative humidity of much of the region - as indicated by records at Las Vegas - ranges from 10 to 30 percent during the summer and from 20 to 60 percent in winter. The mean daily maximum temperature at Las Vegas (sta. alt, 2,162 ft) ranges from $13.0^{\circ} \mathrm{C}$ (Celsius) in January to $40.5^{\circ} \mathrm{C}$ in July; the mean daily minimum temperature for the same months ranges from $0.5^{\circ} \mathrm{C}$ to $24.5^{\circ} \mathrm{C}$; temperatures in the higher valleys, such as in central Yucca Flat (sta. alt, 4,076 ft), are as much as $3.0^{\circ}$ to $8.5^{\circ}$ lower. In Death Valley, in the southwest corner of the study area, temperatures greater than $49.0^{\circ} \mathrm{C}$ are common during the summer months. Annual rainfall in this valley averages about 1.7 inches, and annual pan evaporation is about 150 inches per year (Hunt and others, 1966).

A significant exception to the general aridity of the region is the subhumid climate of the Sheep Range and the Spring Mountains. The precipitation on these mountains generally ranges from 10 inches on the lower slopes to 30 inches on the highest peaks of the Spring Mountains; possibly as much as one-third of this precipitation is snowfall. Thus, the climate of the region ranges from arid on the valley floors to subhumid on the crests of the highest mountains.

Variations in precipitation and temperature cause marked differences in plant life. Creosote bush, burro bush, and a variety of yuccas, which dominate the bajadas below 4,000 feet, give way to blackbrush and joshua trees at slightly higher altitudes. Juniper, pinon pine, and sagebrush dominate above 6,000 feet and are in turn replaced by white fir and yellow pine (Pinus ponderosa) above 7,500 feet (Bradley, 1964).

Precipitation varies markedly with the season, and most precipitation falls during winter and summer. The monthly precipitation at Las Vegas and at the Nevada Test Site is illustrated in figure 2. The mean annual precipitation is shown in figure 3 .

Winter precipitation, originating from the west, is usually associated with transitory low-pressure systems and, therefore, moves over large areas (Quiring, 1965). The summer precipitation, on the other hand, occurs predominantly as convective storms which can be intense over a few square miles and which vary in location from one storm to the next. Summer moisture generally originates from the southeast or south.

Recent studies by Weedfall (1963) and Quiring (1965) showed that precipitation within the study area is a function of altitude and of longitudinal position. Generally, stations east of long $115^{\circ} 45^{\prime}$ receive from 1.5 to 2.5 times more precipitation than stations at similar altitudes but west of long $116^{\circ} 45^{\prime}$. Stations between these longitudes receive intermediate or transitional amounts of precipitation at any given altitude. Reasons for the longitudinal control were outlined by Quiring (1965).

The net effect of the longitudinal and the altitude controls of precipitation is a marked precipitation deficit within the region bounded by lat $36^{\circ} 30^{\prime}$ and $37^{\circ} 15^{\prime}$ and long $115^{\circ} 30^{\prime}$ and $116^{\circ} 15^{\prime}$. Topographically, this area is the lowest part of the study area; moreover, most of it falls within the transition zone outlined by Quiring (1965, fig. 1). Precipitation in this area ranges from 4 to 10 inches and, except for the Amargosa Desert and Death Valley, is the lowest for the region.

Geological, botanical, ecological, and paleontological studies indicate that the entire region at one time had a much wetter climate. As a whole, the evidence suggests 


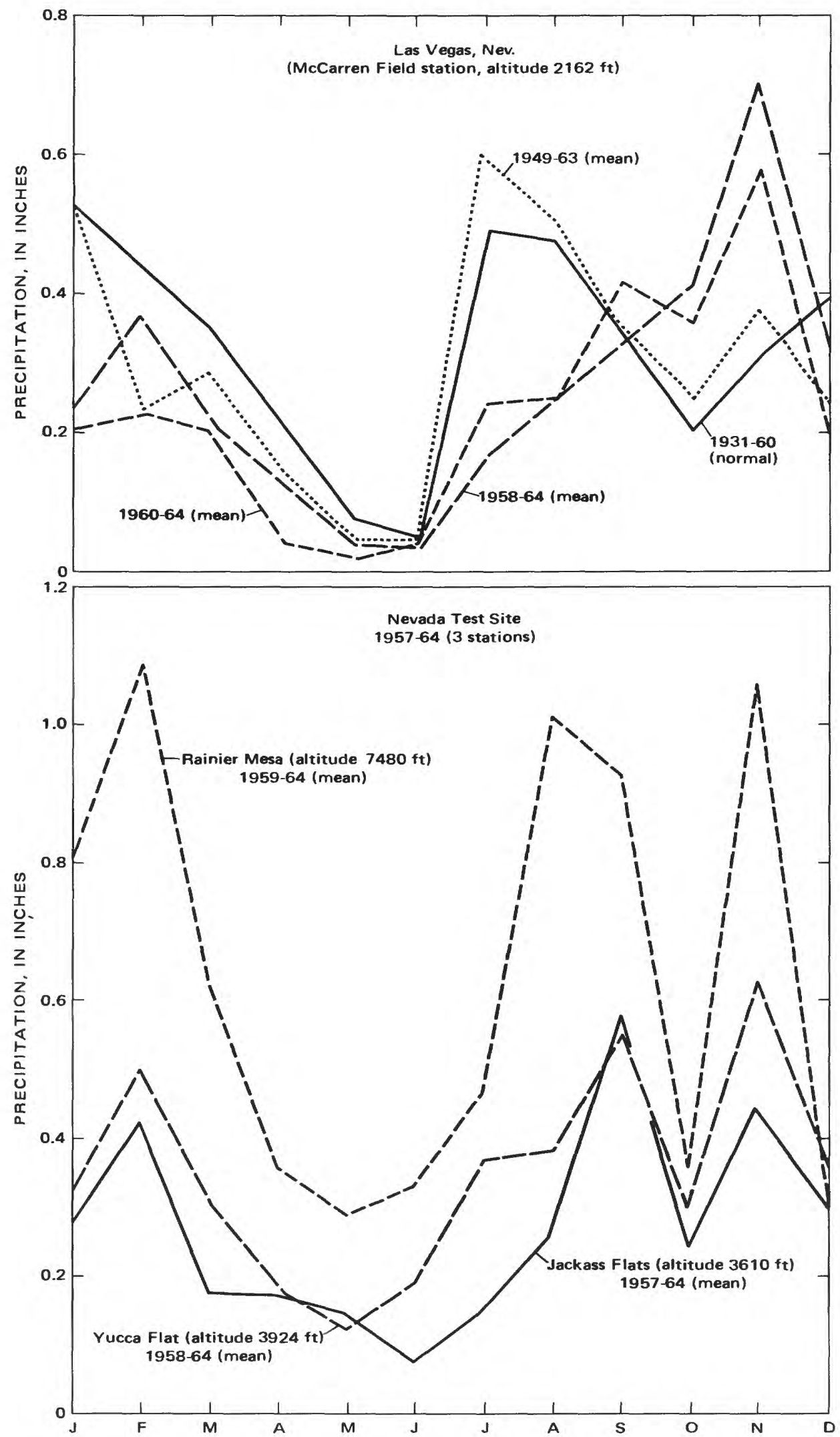

FIGURE 2. - Normal and means of monthly precipitation. 

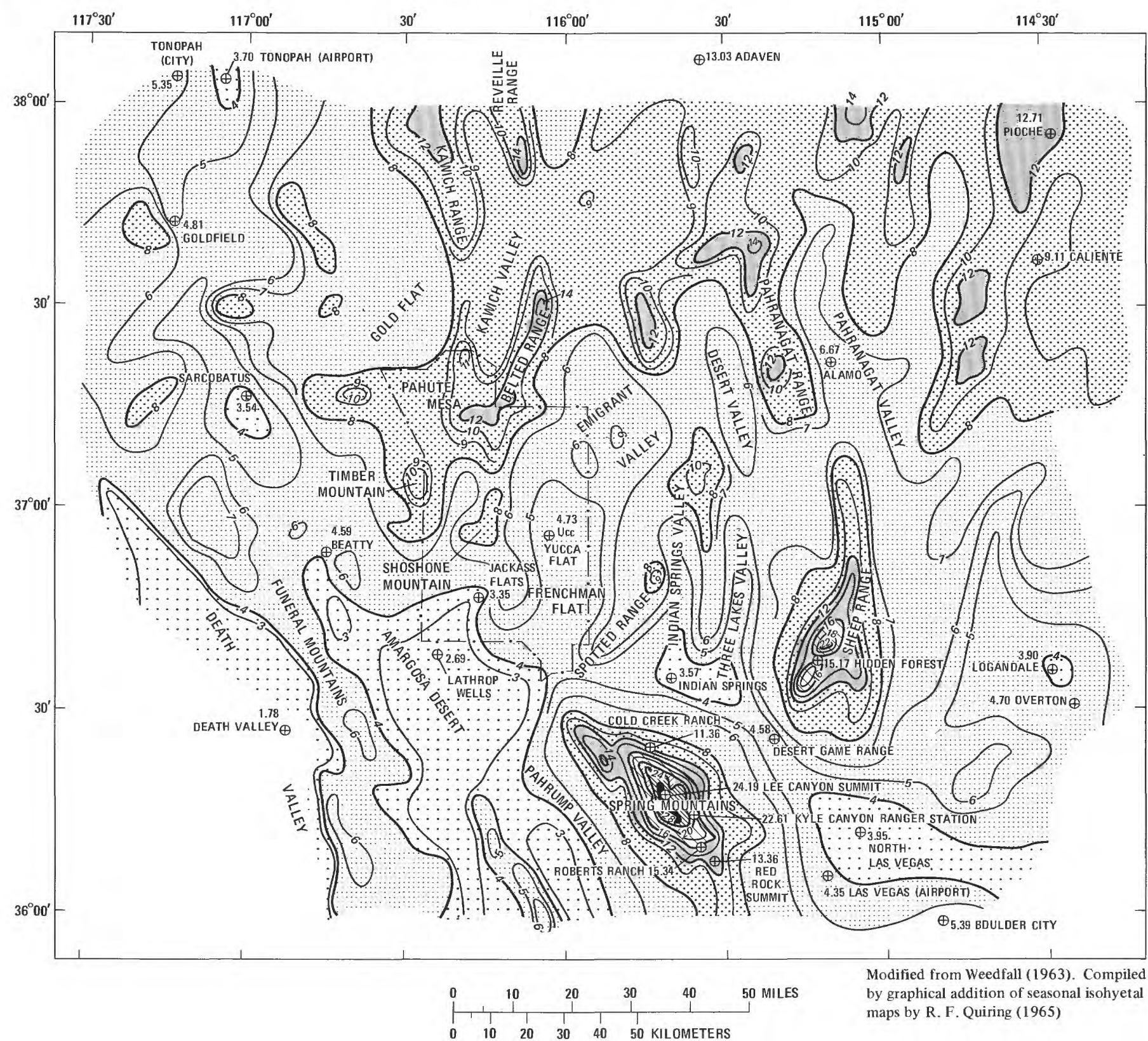

Modified from Weedfall (1963). Compiled by graphical addition of seasonal isohyetal maps by R. F. Quiring (1965)

EXPLANATION

RANGE OF ANNUAL PRECIPITATION, IN INCHES

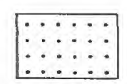

Less than 4

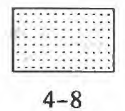

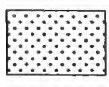
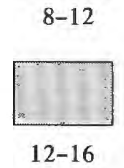

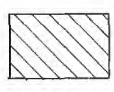

$16-20$

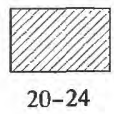

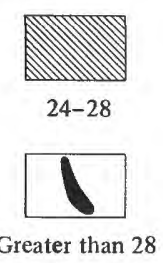

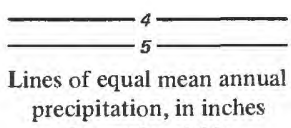

Interval variable $\oplus^{13.03}$ ADAVEN

Weather station

Mean annual precipitation listed

next to station; adjusted to

30-year period, 1931-60

Nevada Test Site boundary

FigURE 3. - Mean annual precipitation.

that several wet periods, or pluvials, occurred during the $\mid$ the evidence for pluvials in the study area were past 70,000 years. The last major pluvial probably presented by Mehringer (1965) and by Wells and closed about 9,000 years ago. Recent reviews of some of Jorgensen (1964). 


\section{GEOLOGIC SETTING}

The Nevada Test Site region is geologically complex. It lies within the miogeosynclinal belt of the Cordilleran geosyncline, in which 37,000 feet of marine sediments accumulated during the Precambrian and Paleozoic Eras. Except for a few small intrusive masses, no rocks of Mesozoic age are found within the study area. The region is also within a Tertiary volcanic province in which extrusive rocks, locally more than 13,000 feet thick, were erupted largely from caldera centers. Quaternary detrital sequences, largely alluvium, fill most of the lowlying areas in the region.

Two major periods of deformation affected the region. The first orogeny occurred in late Mesozoic and perhaps early Tertiary time and resulted in folding and thrust faulting of the Precambrian and Paleozoic rocks. During middle to late Cenozoic time the region underwent normal block faulting, which produced the Basin and Range topography. Displacements along major strike-slip faults, measured in miles, occurred during both periods of deformation.

The description of stratigraphy and structure which follows pertains chiefly to the Nevada Test Site but is applicable in general terms to most of the area of figure 1 . Where differences in the general geology of a specific part of figure 1 and that at the Nevada Test Site exist, they are noted at appropriate places in the text. The outline of stratigraphy and structure presented below is taken from the following sources: Albers (1967); Harley Barnes (U.S. Geol. Survey, written commun., 1965); Barnes and Poole (1968); Burchfiel (1964, 1965); Ekren (1968); Ekren, Rogers, Anderson, and Orkild (1968); Fleck (1970); Hinrichs (1968); Longwell (1960); Longwell, Pampeyan, Bowyer, and Roberts (1965); Noble (1968); Orkild (1965); Poole, Carr, and Elston (1965); Ross and Longwell (1964); Secor (1962); Stewart (1967); and Vincelette (1964).

\section{PRECAMBRIAN AND PALEOZOIC STRATIGRAPHY}

During Precambrian and Paleozoic time, 37,000 feet of marine sediments were deposited in the study area. The region was then part of an elongated subsiding trough, the Cordilleran geosyncline, which covered most of westernmost North America. The eastern part of this trough, dominated by carbonate and mature clastic sediments, is called the miogeosyncline. The miogeosynclinal sediments throughout the Nevada Test Site and the surrounding region have been divided into 16 formations. Names, thicknesses, and gross lithologic character of these formations are summarized in table 1. For detailed stratigraphic descriptions the reader is referred to Burchfiel (1964).

Because of the generally uniform miogeosynclinal sedimentation, 15 of the 16 formations of table 1 (ex- cluding the Devonian and Mississippian rocks) are probably representative of the lithology and the relative thickness of Precambrian and Paleozoic strata in the region extending several tens of miles beyond Nevada Test Site.

In addition to the uniform lithologic character of the formations throughout the study area, the vertical distribution of clastic and carbonate lithologies within the 37,000 -foot sequence is significant. The Precambrian to Middle Cambrian strata, 10,000 feet thick, are predominantly quartzite and siltstone; the Middle Cambrian through Upper Devonian strata, 15,000 feet thick, are chiefly limestone and dolomite, the Devonian and Mississippian rocks of the Yucca Flat area, about 8,000 feet thick, are chiefly argillite and quartzite; and the Pennsylvanian and Permian rocks about 4,000 feet thick, are chiefly limestone. Thus, the Precambrian and Paleozoic sedimentation was marked by two major sequences of clastic and carbonate sedimentation. Minor clastic rocks - the Dunderberg Shale Member of the Nopah Formation, the Ninemile Formation, and the Eureka Quartzite - occur within the lower carbonate sequence.

A lateral variation in lithology and thickness of Devonian and Mississippian rocks contrasts with the lithologic uniformity of other parts of the stratigraphic section. In western Yucca Flat, Jackass Flats, and areas to the west and northwest, the Devonian and Mississippian strata are composed chiefly of clastic rocks (quartzite, siltstone, argillite, and conglomerate), as much as 8,000 feet in thickness, called the Eleana Formation (table 1). However, in the Spotted Range and the Indian Springs Valley, rocks of equivalent age are predominantly carbonate, and they aggregate about 1,000 feet in thickness. Preliminary work by Poole, Houser, and Orkild (1961) indicated that the southeastward transition from clastic to carbonate lithology was probably gradational, but that postdepositional thrust or strike-slip faulting may have obscured the transition.

For this report the clastic Eleana Formation will be considered representative of the Devonian and Mississippian rocks in Yucca Flat, Jackass Flats, and northwestern Frenchman Flat. The predominantly carbonate Monte Cristo Limestone and part of the Bird Spring Formation of the Spring Mountains are tentatively considered representative of time-equivalent rocks in the Spotted Range and Indian Springs Valley.

No major unconformities occur within the miogeosynclinal column. Several disconformities are present but are not marked by deep subaerial erosion of the underlying rocks.

\section{MESOZOIC STRATIGRAPHY}

Rocks of Mesozoic age in the study area consist of 
TABLE 1. - Stratigraphic and hydrogeologic units at Nevada Test Site and vicinity

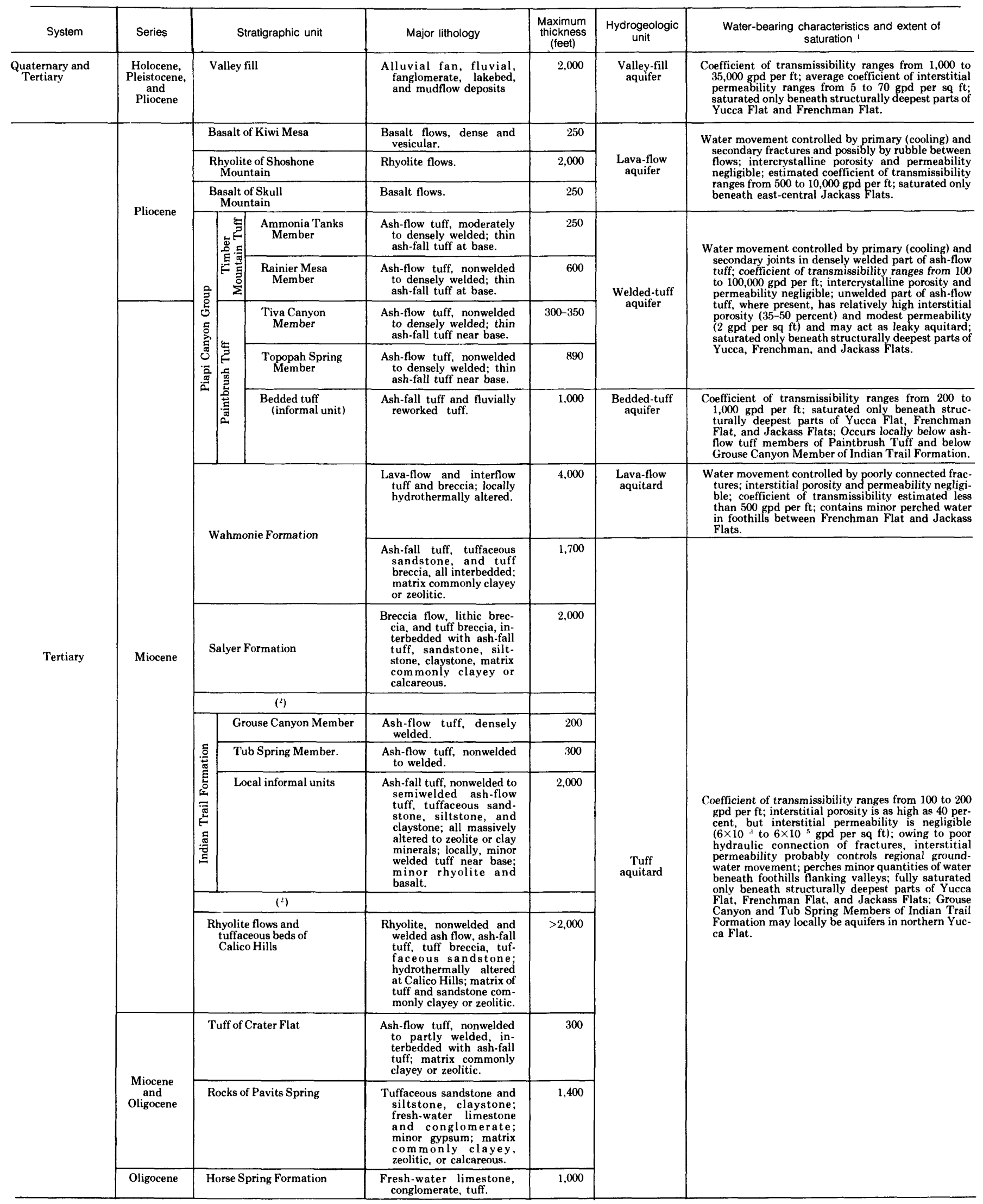


TABLE 1. - Stratigraphic and hydrogeologic units at Nevada Test Site and vicinity - Continued

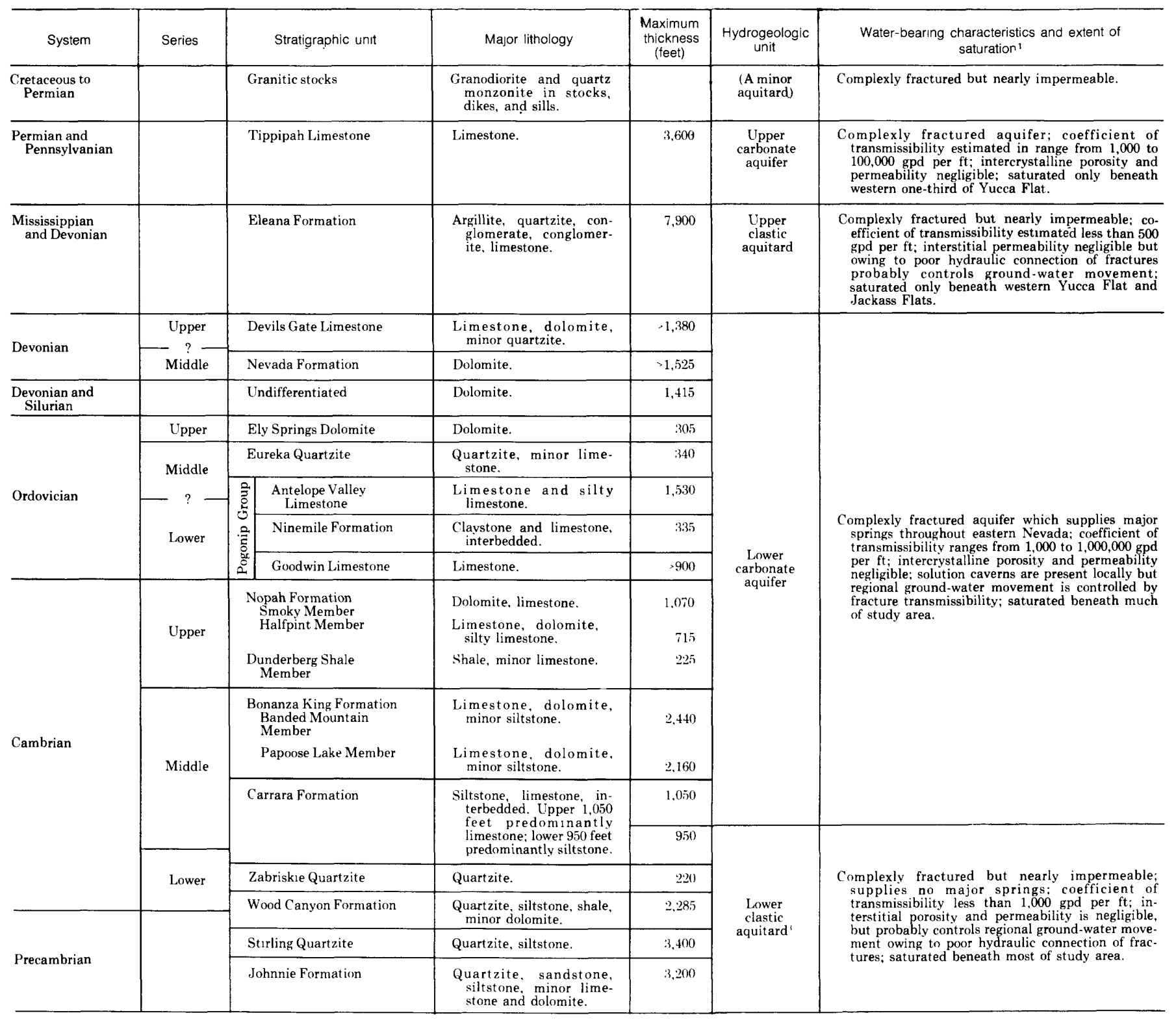

'Coefficient of transmissibility has the units gallons per day The three Miocene sequences occur in separate parts of the 'The Noonday(?) Dolomite, which underlies the Johnnie per foot (gpd per $\mathrm{ft}$ ) width of aquifer; coefficient of region. Age correlations between them are uncertain. They are Formation, is considered part of the lower clastic aquitard.

permeability has the units gallons per day per square foot (gpd placed vertically in table to save space.
per sq $\mathrm{ft}$ ) of aquifer.

several small granitic stocks. No Mesozoic sedimentary rocks occur within the study area. Several thousand feet of Triassic and Jurassic rocks crop out in the southeastern one-third of the Spring Mountains and in the ridges east and northeast of Las Vegas; however, these strata are not known to underlie the Nevada Test Site or its immediate surrounding area.

\section{CENOZOIC STRATIGRAPHY}

Cenozoic volcanic and sedimentary rocks are widely distributed in the region. Tertiary volcanic and associated sedimentary rocks aggregate as much as 6,000 feet in thickness in Yucca Flat, 8,500 feet in western Frenchman Flat and eastern Jackass Flats, more than 5,000 feet in western Jackass Flats, and more than 13,500 feet beneath Pahute Mesa. The volcanic rocks are of both pyroclastic and lava-flow origin and include several rock types. The most common rock types, in order of decreasing abundance, are ash-flow tuff, ash-fall tuff, rhyolite lavas, rhyodacite lavas, and basalt. The tuffs are commonly of rhyolitic and quartz-latitic composition. The Tertiary sedimentary rocks associated with the volcanic 
strata include conglomerate, tuffaceous sandstone and siltstone, calcareous lacustrine tuff, claystone, and fresh-water limestone. The Tertiary rocks are largely of Miocene and Pliocene age, but some are Oligocene. The Quaternary strata generally aggregate less than 2,000 feet in thickness and consist of valley-fill deposits and minor basalt flows.

The Cenozoic strata at Nevada Test Site have been divided into 12 formations and numerous members. These strata are listed in table 1, which also provides information on their thickness, lithologic character, and areal extent. The formations and members are representative of the Cenozoic rocks beneath Yucca Flat, Frenchman Flat, and Jackass Flats; the table is not representative of the volcanic rocks in the Pahute Mesa and Timber Mountain areas of the Nevada Test Site. Yucca Mountain, Pah Canyon, and Stockage Wash Members of the Paintbrush Tuff have been omitted from table 1 because of their limited areal extent and probable absence within the zone of saturation. The table is based on the work of Harley Barnes (written commun., 1965), Orkild (1965), and Poole, Carr, and Elston (1965). The terminology for the pyroclastic rocks described in this report is that of Ross and Smith (1961) and Poole, Elston, and Carr (1965).

Several general characteristics of the Cenozoic pyroclastic rocks, lava flows, and associated sediments are summarized as follows:

1. Areal extent, thickness, and physical properties of each of the Cenozoic volcanic formations vary widely. This irregularity is characteristic of volcanic rocks and is a function of their modes of emplacement, prevailing wind directions, and the topographic relief at the time of their extrusion. Accordingly, the descriptions of lithology and thickness of the Cenozoic formations in table 1 are considered representative only of Yucca Flat, Frenchman Flat, and Jackass Flats.

2. Tertiary rocks generally overlie Precambrian and Paleozoic rocks with angular unconformity. A conglomerate or breccia commonly lies at the base of the Tertiary section on a weathered surface of older rocks. Locally, joints in the older rocks are filled with detritus derived from the overlying basal Tertiary rocks. Evidence of the development of karst terrane on the carbonate rocks beneath the unconformity is absent.

3. The oldest Tertiary rocks were deposited upon a paleotopographic surface of moderate relief developed upon Precambrian and Paleozoic strata. Harley Barnes (written commun., 1965) reports that this erosion surface had a maximum relief of about 2,000 feet. By partly filling the topographic lows, the oldest Tertiary rocks reduced the relief of the area. By late Miocene time, the relief was considerably reduced, as evidenced by the widespread distribution of ash flows of the Paintbrush Tuff.

4. The Miocene and Oligocene rocks up through the basal Wahmonie Formation are of both pyroclastic and sedimentary origin and consist principally of nonwelded ash-flow tuff, ash-fall tuff, tuff breccia, tuffaceous sandstone and siltstone, claystone, and freshwater limestone; lava and welded ash-flow tuff are of minor importance in the area considered. The Pliocene and Miocene rocks above the Wahmonie Formation, in contrast, consist chiefly of welded ash-flow tuff. Nonwelded ash-flow tuff, ash-fall tuff, and tuffaceous sandstone are relatively minor in these younger rocks.

5. The bulk of the Miocene and Oligocene sedimentary rocks appears to be restricted to Frenchman Flat, eastern Jackass Flats, Rock Valley, and Mercury Valley. These strata make up the Rocks of Pavits Spring and the Horse Spring Formation and also are present in the Salyer Formation. Miocene and Oligocene sedimentary rocks are of minor occurrence in Yucca Flat and western Jackass Flats, although the entire section of Tertiary strata in the latter valley has yet to be explored by drilling.

6. The Miocene and Oligocene rhyolitic tuffaceous rocks up through the Wahmonie Formation are generally massively altered to zeolite (clinoptilolite, mordenite, and analcime) or to clay minerals; a vertical zonation of the zeolite minerals in these rocks was described by Hoover (1968). The Miocene and Pliocene rhyolitic tuffs above the Wahmonie Formation, by contrast, either are glassy or have devitrified to cristobalite and feldspar, but they are less commonly altered to zeolite or clay.

\section{STRUCTURAL GEOLOGY}

The structural geology of the region is complex, and details on the general tectonic setting of the study area are available in only a few published reports cited above. About half of these papers are devoted primarily to a single structural feature of the region, the Las Vegas Valley shear zone. The outline of structural geology presented below provides the information needed for subsequent discussions of the disposition of the aquifers and aquitards and the hydraulic barriers within the principal aquifers.

Harris (1959) demonstrated that a large positive area (Sevier Arch) probably existed in much of southeastern Nevada and western Utah from late Jurassic to early Late Cretaceous; thus, Jurassic and Cretaceous strata were probably never deposited within most of the study area. 
The Precambrian and Paleozoic miogeosynclinal rocks were first significantly deformed during late Mesozoic and perhaps early Tertiary time. The deformation was marked by uplift and erosion and subsequent folding, thrusting, and strike-slip faulting that made the region mountainous.

Beginning with the Miocene volcanism and continuing through the Quaternary, large-scale normal block faulting has disrupted the Tertiary volcanic and sedimentary strata as well as the previously deformed Precambrian and Paleozoic rocks. The normal faulting caused the Basin and Range structure reflected by the topography in the region today. In late Tertiary and Quaternary time, the resulting valleys have been largely filled by detritus aggregating several hundred to a few thousand feet. Currently active normal faulting is indicated by fault scarps cutting alluvial fans and by the absence of extensive unfaulted pediments. Some evidence indicates that strike-slip faulting occurred during Tertiary time, some time after deposition of early Miocene tuff (Ekren and others, 1968). This faulting may possibly reflect periodic rejuvenation of strike-slip faults formed during the late Mesozoic orogeny.

Widespread erosion of the miogeosynclinal rocks occurred during and after the late Mesozoic orogeny but before block faulting. Before the first deformation of the region, the Precambrian and Lower Cambrian clastic rocks were buried at depths of at least 15,000 feet in the eastern half of the study area and about 27,000 feet in the western half. Today, these strata are exposed in several areas. They form the bulk of the northwest onethird of the Spring Mountains, a significant part of the Groom and Desert Ranges, and the bulk of the Funeral Mountains. Their distribution, a function of geologic structure and depth of erosion, exercises significant control over the regional movement of ground water. Plate 1 shows the areal extent of dominantly clastic pre-Tertiary strata and the relation of these strata to some major thrust faults and folds.

In contrast to the miogeosynclinal rocks, the postdepositional distribution of Tertiary rocks has been controlled principally by fairly simple block faulting and erosion. The northwestern part of the area is a faulted and eroded volcanic plateau of which Pahute and Rainier Mesas (fig. 1) are remnants. In the remainder of the area, ridges of pre-Tertiary rocks interrupt the continuity of the once extensive ash-flow sheets.

Thurst faults are perhaps the most spectacular of the tectonic features of the region. Thrust faulting displaced the pre-Tertiary rocks laterally a few thousand feet to several miles. Locally, imbricate thrusting repeatedly stacked the miogeosynclinal strata upon one another. Some major thrust faults, though folded, crossfaulted, and eroded can be followed in outcrop or reconstructed for miles (pl. 1).
Some workers (Burchfiel, 1965; Secor, 1962) believe that the major thrust faults, which commonly have dips of $35^{\circ}-50^{\circ}$, flatten with depth and follow less competent strata, specifically the shales of the Carrara Formation; that is, the thrusting is of the décollement type, where the sedimentary rocks slide over the crystalline basement. Vincelette (1964) and Fleck (1970) rejected the décollement hypothesis; they presented evidence that the relatively steep. dip of the major thrust faults remains unchanged with depth.

Strike-slip faults and shear zones cut and offset the thrust faults in several places within the region. The best documented of these is the Las Vegas Valley shear zone (Longwell, 1960). This zone (structural feature 13 on pl. 1 ) is expressed topographically by a valley that extends from Las Vegas nearly to Mercury, a distance of about 55 miles. The amount and the direction of movement along this shear zone has been estimated from structural and stratigraphic evidence to be 15 to 40 miles. Other strikeslip zones, most of which are of smaller displacement than the Las Vegas Valley shear zone, have been mapped in Death Valley, the Spring Mountains, and the Amargosa Desert and at the Nevada Test Site. Some of these faults may be structurally related to the Las Vegas Valley shear zone (E. B. Ekren, written commun., May 1966).

Normal faults, numbering in the thousands within the study area, are the most common tectonic features of the region. Generally the displacement along these faults is less than 500 feet, but it is thousands of feet on some. The normal faults are responsible for the characteristic Basin and Range topography of the region.

Several large anticlines and synclines occur within the area (Longwell and others, 1965; Tschanz and Pampeyan, 1961). Approximate axes of some of these folds are shown on plate 1 . These broad folds were formed before the beginning of extensive sedimentation and volcanism in the Miocene; they parallel other features of the late Mesozoic deformation and probably formed during that episode.

Thrust, strike-slip, and normal faults and the folds that may influence the regional movement of ground water are shown on plate 1 . Most of the structures shown were taken directly or by inference from the geologic maps of Clark and Lincoln Counties (Longwell and others, 1965; Tschanz and Pampeyan, 1961), from unpublished data on the Amargosa Desert by R. L. Christiansen, R. H. Moench, and M. W. Reynolds (U.S. Geol. Survey), and from unpublished data on the Yucca Flat area by Harley Barnes (U.S. Geol. Survey).

\section{PRINCIPAL AQUIFERS AND AQUITARDS}

Ground-water hydrology of the region can be most advantageously discussed by grouping the numerous 
geologic formations and members into units of hydrologic significance. Accordingly, the 29 formations listed are grouped into 10 hydrogeologic units (table 1) in order of decreasing age as follows: Lower clastic aquitard; lower carbonate aquifer; upper clastic aquitard; upper carbonate aquifer; tuff aquitard; lavaflow aquitard; bedded-tuff aquifer; welded-tuff aquifer; lava-flow aquifer; and valley-fill aquifer.

\section{AQUIFERS}

Of the six aquifers listed in table 1 , the lower carbonate and the valley-fill aquifers have the widest areal distribution and are the principal aquifers within the region. In the Las Vegas Valley, only the valley-fill deposits are presently tapped for water supply because of the great depth to the underlying carbonate rocks. In parts of the Nevada Test Site where the valley fill is unsaturated or absent, the lower carbonate aquifer provides the sole source of ground water. Within the Amargosa Desert, on the other hand, some irrigation wells may tap both the valley-fill and the lower carbonate aquifers. The remaining four aquifers have a limited occurrence within the zone of saturation, although locally, as in western Jackass Flats, the welded-tuff aquifer is the sole source of water.

Geologic character and hydraulic properties of the aquifers vary widely. The lower and the upper carbonate aquifers and the welded-tuff aquifer store and transmit ground water chiefly through secondary openings developed along fractures. The bedded-tuff and the valley-fill aquifers, on the other hand, store and transmit water chiefly through primary or interstitial openings.

\section{LOWER CARBONATE AQUIFER}

The lower carbonate aquifer comprises the carbonate rocks of Middle Cambrian through Devonian age - that is, all the formations from the upper half of the Carrara Formation through the Devils Gate Limestone (table 1). ${ }^{1}$ These carbonate strata aggregate about 15,000 feet in thickness, but as a result of the deep erosion of the deformed miogeosynclinal rocks this thickness is rarely present in any one location. The saturated thickness of the carbonate strata, which ranges from a few hundred feet to several thousand feet, is due to the combined influence of geologic structure, erosion, and depth to water table. In general, however, because of the great aggregate thickness and stratigraphic position of the rocks composing the lower carbonate aquifer, several thousand feet of the aquifer occurs within the zone of saturation throughout most of the study area; the aquifer is completely unsaturated or eroded only in the vicinity of the outcrops or buried structural highs of pre-Middle Cambrian clastic rocks (pl. 1).

'In southern Indian Springs valley, carbonate rocks of Mississippian, Pennsylvanian, and Permian age (Monte Cristo(?) Limestone and Bird Spring Formation) are also included in the lower carbonate aquifer.
CHARACTER IN OUTCROP

Outcrop studies provided qualitative information on the nature of the intercrystalline (or matrix) openings, the character of fractures and bedding-plane partings, the occurrence of caverns, and the stratigraphic control of secondary openings in the carbonate strata.

The intercrystalline porosity of the carbonate rocks is extremely low. Hand specimens examined ranged from fine grained to coarsely crystalline, and the calcite or dolomite crystals composing the rock were tightly intergrown. Vugs as much as 0.4 inch in diameter were observed in some hand specimens, but no interconnected vuggy porosity was noted.

The carbonate rocks are highly fractured and locally are brecciated. Most outcrops exhibit three or more sets of joints, one or more high-angle faults, and one or more brecciated zones. The joints, and most of the faults, are high-angle fractures (fig. 4). Brecciation commonly occurs along faults of only a few feet displacement and does not necessarily reflect movement of large magnitude.

Strike and frequency of the faults and joints vary considerably from area to area. Even within an area of a few square miles the strike of the high-angle faults may differ from fault block to fault block. Harley Barnes and

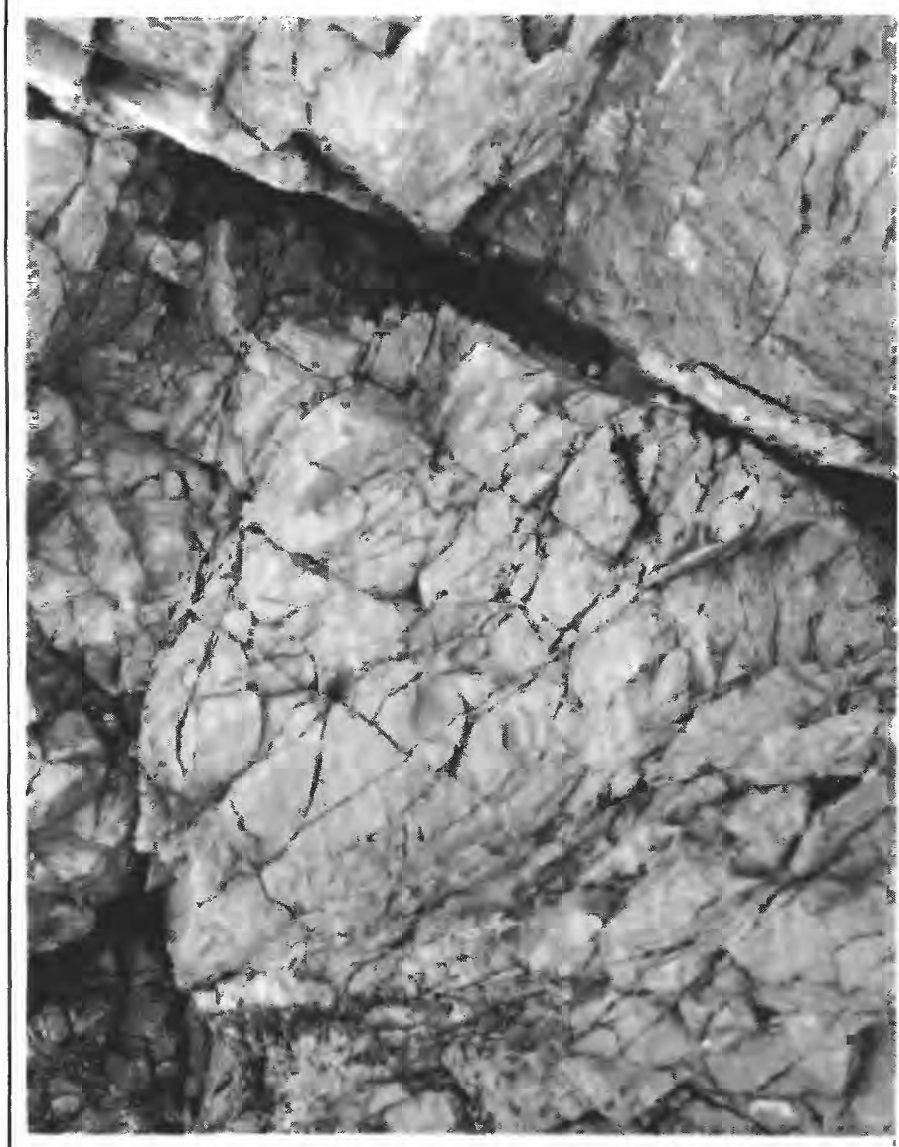

Figure 4. - Intensely fractured Silurian dolomite in the Spotted Range. Bedding-plane opening above pencil. 
associates (written commun., 1965) tabulated the frequency distribution of 933 high-angle faults mapped in eight $7 \frac{1}{2}$-minute quadrangles covering the Yucca Flat area. The dominant strikes range from N. $20^{\circ}-30^{\circ} \mathrm{W}$. to N. $20^{\circ}-30^{\circ} \mathrm{E}$. Burchfiel (1965) tabulated the strikes of 384 faults in six different parts of the 15-minute Specter Range topographic quadrangle. The dominant strikes ranged from about N. $75^{\circ} \mathrm{E}$. to N. $45^{\circ} \mathrm{W}$.

Differences in character and frequency of joints in Yucca Flat were documented by Messrs. David Cummings, R. P. Snyder, and D. L. Hoover (written commun., Nov. 1963). They measured the length and orientation of 1,845 joints in the Tippipah Limestone of Permian and Pennsylvanian age (the upper carbonate aquifer of this report) in west-central Yucca Flat in a plot 300 by 400 feet (Nevada coordinates, central zone, N. $855,200 \mathrm{ft} ; \mathrm{E} .651,000 \mathrm{ft}$ ). The slope of the rock surface is about $5^{\circ}$ eastward. The rock is a thin-bedded to very thick bedded (3-18 in.) finely crystalline limestone. Although faults are numerous in the area, only one normal fault, having a length of 15 feet and a displacement of a few feet, was observed. In addition to outcrop measurements, Messrs. David Cummings, R. P. Snyder, and D. L. Hoover (U.S. Geol. Survey) studied 280 feet of core from six holes in or within 150 feet of the study plot; the holes were as much as 200 feet in depth. Their major findings pertinent to this study follow:

1. Most fractures were filled with secondary calcite, calcareous clay, or calcareous clay containing iron oxide.

2. Two major joint sets and three minor sets were mapped. The major joints ranged from 0.8 to 9 feet in length and from 0.1 to 0.4 inch in width. The minor joints ranged from 0.15 to 6 feet in length and were less than 0.1 inch in width.

3. The number of joints in core ranged from 5 to 43 per foot; the median value was 18 per foot. Dip of the fractures ranged from nearly horizontal to vertical but was generally steeper than $45^{\circ}$.

4. Selected stratigraphic intervals were traced from one drill hole to another, but joint frequencies and dips in cores from a given stratigraphic interval could not be correlated between holes.

5. The maximum dimension of 72 percent of individual limestone blocks bounded by fractures was less than 0.3 foot; 97 percent had a maximum length less than 0.7 foot; and 99 percent had a dimension less than 1 foot.

Joint patterns in Banded Mountain in northeastern Yucca Flat and in the Ranger Mountains in southern Frenchman Flat were studied by P. J. Barosh (written commun., Aug. 1965). He distinguished both local and throughgoing joints in the Paleozoic rocks. The local joints differ in number and direction from bed to bed, and some are confined to a particular bed or group of beds. The local joints generally have consistent trends in an area a few tens of feet in diameter. Most of the local joints are perpendicular to the bedding, but some are parallel to the bedding.

Throughgoing joints sets described by Barosh cut many beds without change in direction or number. These joints have consistent trends within areas 50 to several hundred feet in diameter and commonly have a moderately uniform spacing of 0.5 foot to 2 feet. Most of these joints are nearly perpendicular to bedding, although some locally intersect bedding at oblique angles. The throughgoing joint sets are parallel to an associated fault set.

Barosh also found that joint density bears a strong relationship to rock type. Fine-grained carbonate rocks have the greatest joint density of any studied. The joints generally cut this rock into blocks ranging from 1 inch to a few inches on a side. Medium-grained carbonate rocks are cut into blocks ranging from a few inches to 1 foot on a side. Coarse-grained carbonate rocks are cut into blocks commonly ranging from 6 inches to 2 feet on a side.

In outcrops, subaerial chemical and mechanical weathering have increased the fracture porosity within a few feet to tens of feet of the surface. Near-surface solution widens fractures and may remove the calcite that lines or fills them. Because of the influence of subaerial weathering, a qualitative estimate of the fracture porosity expected in the subsurface cannot readily be made from outcrop study.

Significant differences in the degree of fracturing of the carbonate rocks above and below low-angle faults were noted. The fracturing and brecciation is most intense where the carbonate rocks compose segments (klippen) of the upper plate of low-angle thrust faults. Such plates crop out in several parts of the study area. R. H. Moench (written commun., Mar. 1965) described a few such plates in the unnamed hills bordering Pahrump Valley on the northwest, where faults separating the upper from the lower plates are nearly horizontal or are parallel to the bedding of the lower plate. The rocks composing the upper plate are described by Moench as "thoroughly brecciated." Secor (1962) noted numerous "landslide deposits" of carbonate-rock detritus along the southwest margin of the Spring Mountains adjacent to Pahrump Valley. The landslide masses commonly rest on carbonate bedrock, cover earlier thrust and normal faults, and are themselves partly buried by younger alluvium. They are commonly monolithologic, are thoroughly recemented, and represent stratigraphic units of Cambrian through Permian age. Secor believed that these masses may have moved as much as 7 miles from their source. The texture of the landslide masses he described ranges from large blocks of undeformed rock, in which bedding can be traced for hundreds to 
thousands of feet, to completely disordered angular breccias with average particle diameter of less than 1 inch. One slide described by Secor (1962) may be as much as 2,000 feet thick. A megabreccia of carbonate rock overlying Tertiary tuffs a few miles east of Shoshone, Calif. was examined by the senior author of this report. In contrast to the thoroughly cemented landslide block described by Secor, the megabreccia east of Shoshone locally contains considerable porosity between blocks composing the deposit. In summary, outcrop evidence indicates that the klippen(?) and landslide plates of carbonate rocks may be zones of above-average porosity and fracture transmissibility where they occur within the zone of saturation.

The cited outcrop studies of joints and faults illustrate the heterogeneous nature of the fractures cutting the Paleozoic carbonate rocks. In many parts of Nevada Test Site, the carbonate rocks have been subjected to more intense structural deformation than the rocks described.

Secondary openings are present locally along bedding planes in the carbonate rocks, but widespread development of openings along such planes is absent. Some of the bedding-plane openings may be due entirely to subaerial mechanical and chemical weathering, but some may be due, in part, to solution of the rock within the vadose zone or in the zone of saturation. For example, downslope slippage of strata along bedding planes has probably produced some of the openings visible along these planes. Elsewhere, solution (presumably in the subsurface) has dissolved small smooth tabular openings that are strung out along otherwise tightly closed bedding and joint planes (fig. 5). Veins of banded calcite, 1 to several inches thick, occur locally along bedding planes. At places, solution of this calcite has left tabular openings several feet long and of unknown depth along the bedding plane (fig. 4). In general, the openings seldom extend more than several feet along the plane.

Neither stratigraphically controlled regional solution of the carbonate rocks nor significant solution below the major Tertiary-pre-Tertiary unconformity is evident. The absence of stratigraphically controlled solution is not unexpected because of the absence of disconformities marked by significant erosion in the Paleozoic rocks older than Late Devonian. No field evidence suggests that sinkholes or karst topography exist in, or were developed on, the carbonate rocks beneath the Tertiary-pre-Tertiary unconformity. Field and subsurface evidence from a few holes indicates that the fractures within the uppermost part of the carbonate rocks are commonly filled by tuffaceous or lacustrine detritus derived from the Tertiary rock above the unconformity.

All the carbonate-rock formations composing the lower carbonate aquifer contain small isolated caves. These caves seldom exceed 20 feet and are generally less than 10 feet in maximum dimension. In some outcrops

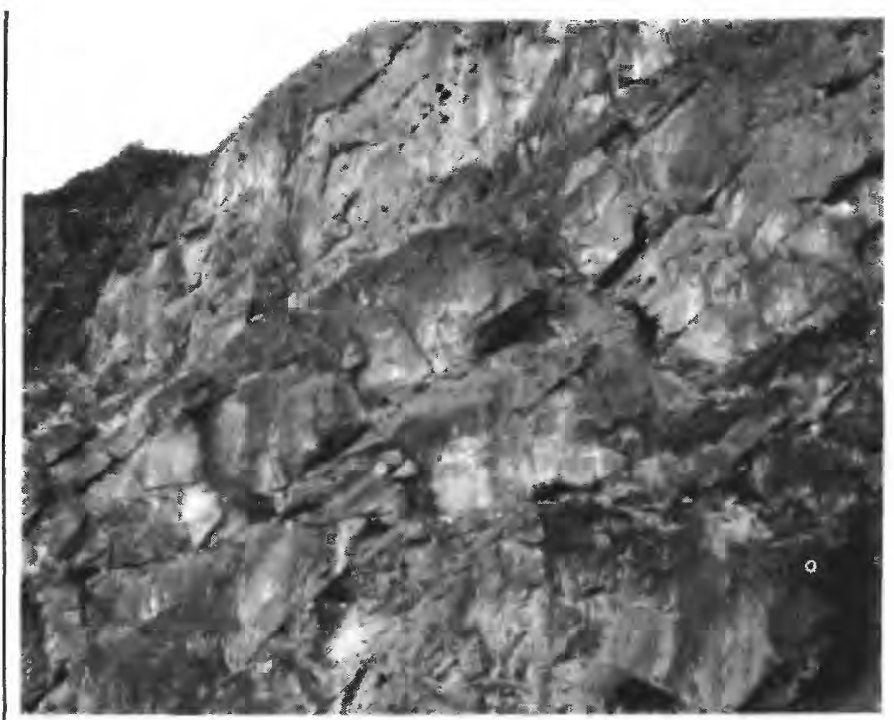

FIGURE 5. - Secondary openings along bedding and joint planes in Cambrian(?) carbonate rocks, Titus Canyon, Death Valley National Monument, Calif. Openings in middle ground, up to 10 feet long.

the caves are abundant and may be found every few tens of feet within a particular stratum; in nearby outcrops of the same formation, they may be totally absent. The caves range from nearly rectangular to roughly spherical. Some have small openings that widen inwardly. Locally, the caves tend to develop along major fault zones, but fault zones seemingly do not characteristically control formation of these caves.

Most of the small caves examined probably originated as weathered-out joint or fault blocks. The characteristic smallness of the caves and their lack of interconnection with adjacent caves probably precludes a solution origin. The most convincing evidence that the small caves are not due to solution is their general absence on dip slopes, although they are locally well developed on cliff faces of a given formation. Mechanical and subaerial chemical weathering on cliff faces can readily dislodge blocks outlined by steeply dipping joints, whereas such dislodgement is much more difficult on dip slopes. If the caves were of solution origin they should be visible on dip slopes. Caves with openings smaller than their interior dimensions may be solely due to solution; these caves cannot be readily ascribed to weathering out of joint blocks.

In contrast to the many unconnected caverns of minor dimension seen in outcrop at the Nevada Test Site, Devils Hole and Gypsum Cave represent two major solution features developed within the carbonate aquifers. Devils Hole is a water-filled funnel-shaped cavern at Ash Meadows, in the SW $1 / 4 \mathrm{SE}^{1 / 4}$ sec. 36, T. $17 \mathrm{~S}$., R. 50 E., about 23 miles southwest of Mercury (figs. 1 and 34). The cavern is at the south end of a ridge composed of the Bonanza King Formation. At ground level, the 
northeastward-trending opening is about 70 feet long and 30 to 40 feet wide. At water surface, about 50 feet below the general land surface, the pool of water is about 40 feet long and 10 feet wide (Worts, 1963). Since 1950, speleologists using scuba equipment have explored the cavern several times (Halliday, 1966, p. 273). A sketch map of the cavern (Halliday, 1966, p. 281) shows several rooms and passageways. The speleologists reported that at depth the cavern follows a fault having a dip of $70^{\circ}$ and a width of about 20 feet (Worts, 1963). Intensive search in July 1965 for two missing scuba divers indicated that the solution passages probably extend more than 315 feet beneath the pool level (Las Vegas Sun, June 23,1965$)$, or more than 365 feet below the land surface.

Devils Hole seems to be structurally controlled (Worts, 1963) by a nearly vertical fault, which strikes about $\mathrm{N} .40^{\circ} \mathrm{E}$. The major fault zone, exposed along the entrance to the cavern, is as much as a yard wide and consists of a breccia of carbonate rock completely cemented by calcium carbonate.

Gypsum Cave, a world-famous archeological site, is in the $\mathrm{SE}^{1 / 4} 4$ sec. 11, T. 20 S., R. 63 E., about 13 miles eastnortheast of Las Vegas. A detailed description of this cave and of its archeological significance was presented by Harrington (1933). Gypsum Cave was formed in carbonate rocks of Permian age. The cavern received its name from deposits of selenite crystals, which are abundant in one of the rooms. The cave mouth is in a low limestone spur and is about 150 feet above the adjacent bajada. The entrance is about 70 feet wide and about 15 feet high. Overall, Gypsum Cave is about 300 feet long and as much as 120 feet wide in its widest part.

In addition to Devils Hole and Gypsum Cave, several other large caves in the Spring Mountains and one near the crest of Worthington Mountain east of Penoyer Valley (Sand Spring Valley) have been reported. The size and extent of these caves are unknown.

\section{CHARACTER BASED ON CORES, DRILLING RECORDS, AND GEOPHYSICAL LOGS}

The subsurface character of the lower carbonate aquifer was studied through microscopic (binocular) examination of cores and cuttings, laboratory measurement of the intercrystalline porosity and permeability of cores, and examination of drilling-time logs and selected geophysical logs. Study of cores and cuttings, as a guide to the type and amount of secondary porosity, was subject to the limitations common to most subsurface geologic work, namely: (1) In most holes the footage cored was only 5 to 90 percent of the hole depth; (2) major openings along fractures or bedding planes are not sampled by coring and vuggy openings covering an area equal to or greater than the diameter of the hole are commonly destroyed during coring; (3) open or vuggy frac- tures successfully cored are not necessarily connected to other open fractures in the formation; and (4) cuttings generally are poor indicators of secondary porosity. Despite these limitations, examination of cores and cuttings and the laboratory analyses of the cores yielded valuable qualitative information on the subsurface character of the aquifer.

Intercrystalline, or matrix, porosity and permeability of cores from formations composing the lower carbonate aquifer are extremely low, as shown in table 2 . The totalporosity data were obtained by comparing bulk density and grain density of the cores and, therefore, include the sum of the unconnected, or isolated, intercrystalline porosity and the effective, or interconnected, porosity. The effective porosity was determined by the mercury injection or water-saturation method. Permeability tests were run using Denver, Colo. tap water. Although the number of cores analyzed is small, they represent several hundred feet of cores (from eight test holes) examined both megascopically and microscopically. Several dozen additional measurements of total porosity of outcrop and core samples (not included in the tabulation) confirm that the total-porosity values tabulated are representative.

Four types of fractures were distinguished in the cores: (1) fractures filled with breccia or clayey gouge; (2) slickensides; (3) fractures sealed with calcite, dolomite, or other minerals; and (4) fractures partly filled with calcite or dolomite. The first three types of fractures contained little or no effective (interconnected) porosity, although they commonly contained isolated vugs. Fractures filled wtih breccia or clayey gouge are probably fault planes. Breccia generally consists of angular carbonate rock fragments densely cemented by calcite or dolomite. Vuggy porosity is locally present in breccias, but in general the vugs are isolated. Breccias, though not common, filled the thickest of the sealed fractures observed; zones ranged in thickness from a few inches to many feet. Fractures filled with clayey or shaly gouge were common in intervals of interbedded carbonate rock and shale (fig. 6). The effective porosity of the gougefilled fractures is probably moderate, but the permeability of the gouge is no greater than that expected in shale or clay.

The slickensides were tightly sealed or contained a fill-

TABLE 2. - Intercrystalline porosity and permeability of cores from lower carbonate aquifer, Nevada Test Site and vicinity

[Total porosity, in percent, determined from grain and bulk densities; effective porosity, in percent, determined by mercury-injection or water-saturation methods; permeability, in gallons per day per square foot,
Geol. Survey, Denver, Colol

\begin{tabular}{|c|c|c|c|c|}
\hline $\begin{array}{l}\text { Porosity or } \\
\text { permeability }\end{array}$ & $\begin{array}{l}\text { Number of } \\
\text { samples }\end{array}$ & Range & Median & Mean \\
\hline $\begin{array}{l}\text { Total porosity } \\
\text { Effective porosity }\end{array}$ & $\begin{array}{l}16 \\
25\end{array}$ & $\begin{array}{l}0.4-12.4 \\
0.0-9.0\end{array}$ & $\begin{array}{l}5.5 \\
1.1\end{array}$ & $\begin{array}{l}5.4 \\
2.3\end{array}$ \\
\hline Permeability & 13 & $0.00002-0.1$ & .00008 & .01 \\
\hline
\end{tabular}




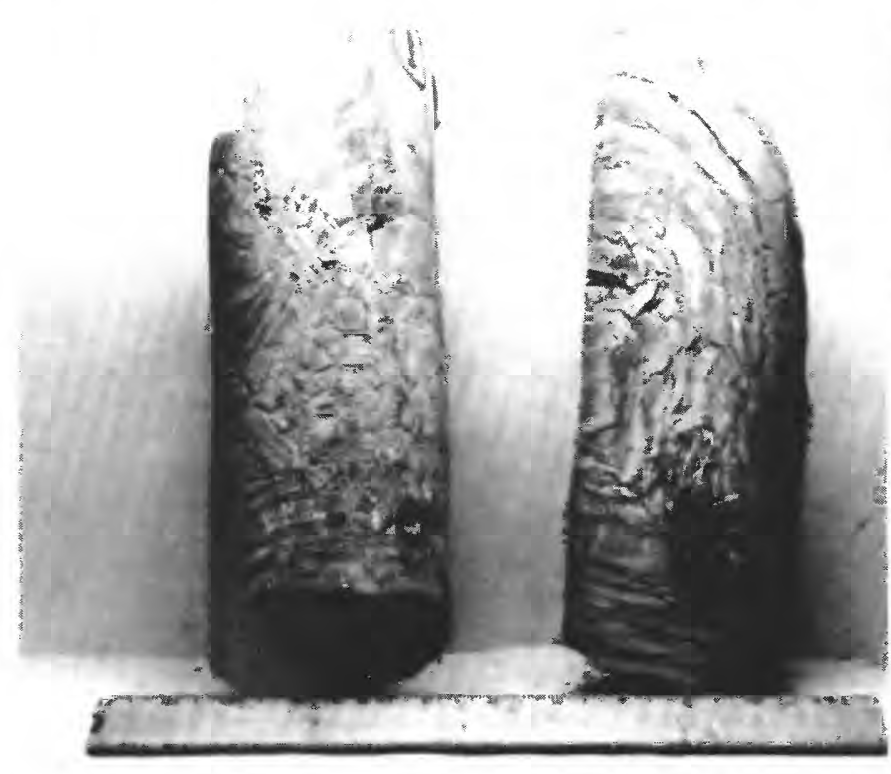

FiguRE 6. - Structure in cores of Pogonip Group, well 88-66, Yucca Flat. Left core (depth 2,980 ft), folded limestone (light gray) and shale (medium gray). Right core (depth $2,983 \mathrm{ft}$ ), fault breccia of limestone fragments. In both cores the fragmented limestone is tightly cemented by clayey or shaly gouge.

ing of gouge material. These fractures averaged three per 100 feet of core logged. Most of them dip at angles between $25^{\circ}$ and $90^{\circ}$, are generally less than 0.04 inch thick, and extend entirely across the cores.

Fractures sealed with calcite or dolomite veinlets or, to a lesser extent, with quartz, iron and manganese oxides, or clay are the most abundant type of fractures in the cores. They amounted to an estimated 95 percent of all the fractures found, and in some holes the carbonate veinlets constituted an estimated 5 percent of the volume of rock cored. These fractures averaged about 10 per foot of core and ranged from 1 to 30 per foot of core. Most of them dip at angles greater than $45^{\circ}$ and are less than 0.1 inch thick. They rarely attain a thickness of 0.4 inch. The larger veinlets extend entirely across the cores, whereas the smaller veinlets form complex branching or angular patterns among the larger veinlets. The veinlets are commonly offset a fraction of an inch to several inches at their point of intersection with other veinlets. Some of the fractures have only a thin crust of iron oxide, manganese oxide, or clay. These fractures appear to be joints - that is, fractures with little or no visible displacement parallel to the fracture plane. The fractures sealed with calcite, dolomite, or other minerals contain isolated vugs, but effective porosity is negligible.

The partly filled fractures range from those containing only a thin coating of calcite or dolomite on the fracture planes to fractures filled with vuggy calcite or dolomite veinlets (figs. 7 and 8 ). The vuggy veinlets probably originated by solution of the carbonate veinlets that fill

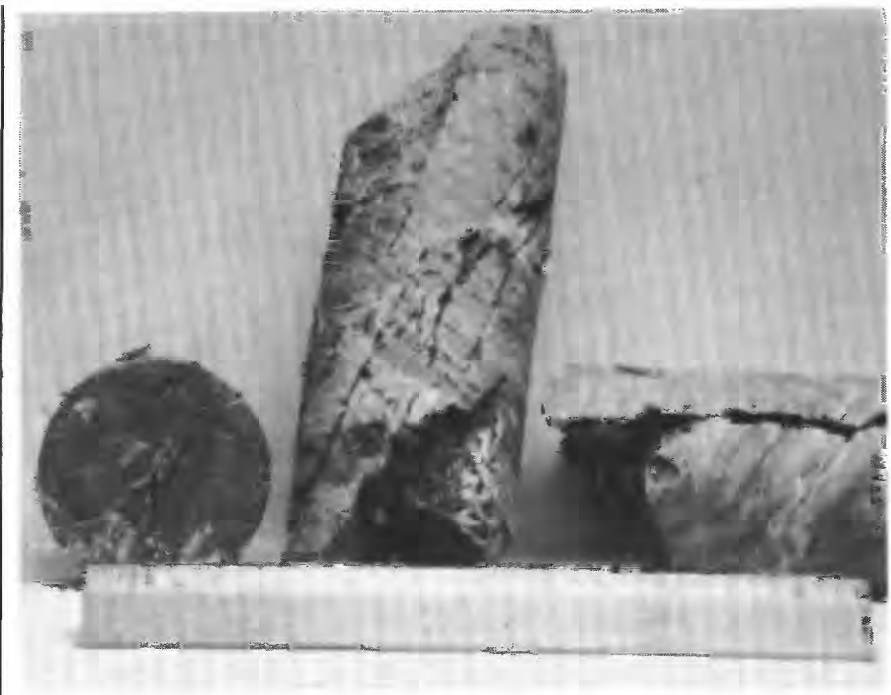

FIGURE 7. - Sealed, vuggy, and open fractures in cores of carbonate rock from the Pogonip Group, well 88-66, Yucca Flat. Cores are from depths of 2,705 to 2,787 feet below surface.

most of the fractures in the cores. Some of the open fractures lined with carbonate minerals also probably originated by solution along fractures, which was followed by some mineral precipitation. Other open fractures were probably never sealed and are in the process of being filled. That the secondary porosity in the vuggy veinlets and along some of the unfilled fractures is due to solution is suggested by the following: (1) Better development of porosity along the intersection of fractures; (2) variable width of the individual fractures; (3) vugs that appear to be due to solution of fossils; (4) a decrease with depth in the abundance, degree of openness, and continuity of vugs; and (5) better development of porosity in limestone than in dolomite.

Partly filled fractures are less abundant than those sealed by carbonate veinlets and amount to 1 to 5 percent of the fractures found. They averaged about five per 100 feet of core and ranged from zero to one fracture per 2 feet of core. Fractures containing vuggy veinlets are probably twice as abundant in holes penetrating limestone as in holes penetrating dolomite. In general, the vuggy veinlets dip at high angles, are 0.02 to $0.1 \mathrm{inch}$ thick, and rarely attain a thickness of 0.4 inch. Most of them extend entirely across the cores. Most of the partly filled fractures in the cores (fig. 7) were parallel, but a few intersected.

Total porosity of the partly filled fractures is estimated to average 0.1 percent and to range from 0 to 1 percent of the volume of the core. Effective porosity of the fractures with vuggy veinlets is even lower because most of the vugs are probably isolated within the matrix of carbonate vein material and are therefore either very poorly, or not at all, hydraulically connected. 


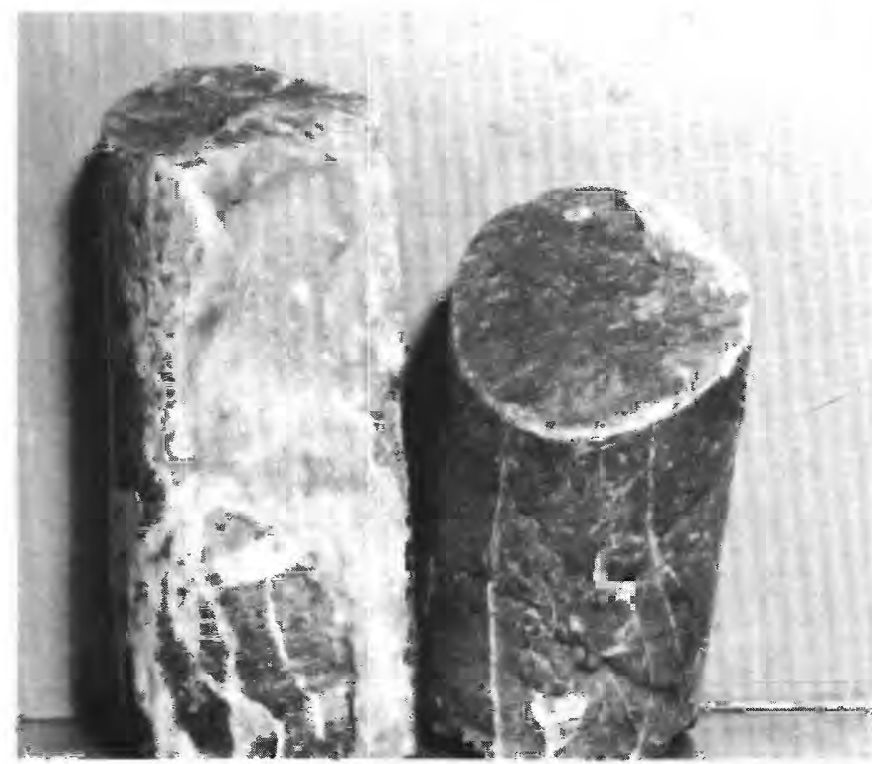

FIGURE 8. - Sealed and vuggy fractures and slickenside with red clay in limestone core from the upper part of the Carrara Formation, well 79-69a, Yucca Flat. Core is from 1,411 feet below surface and is $21 / 8$ inches in diameter.

In general, core examination suggests that secondary porosity is better developed along fractures with minor displacement than along fault planes.

Stylolites also are common partings in cores, but they are generally completely sealed with clayey residues. They averaged three per foot of core and ranged from zero to 30 per foot. They are most conspicuous and probably most abundant in limestone. They dip at low to high angles to the core axis and are probably parallel to bedding planes. Effective porosity along the stylolites appeared to be negligible. In only one test hole, well 67-68, was significant solution widening of stylolites noted in limestone.

R. D. Carroll of the U.S. Geological Survey (written commun., 1966) used geophysical logs to estimate the fracture porosity of the lower carbonate aquifer for test wells 88-66, 73-66, and 89-68. The interpretations pertinent to test well 88-66 were presented by Moore, Doyle, Walker, and Young (1963).

R. D. Carroll estimated the total (that is, intercrystalline and fracture) porosity of selected fractured intervals utilizing density and neutron logs in conjunction with caliper logs. He also used a group of geophysical logs (density, neutron, sonic, and electric) to estimate intercrystalline (matrix) porosity in nearly unfractured intervals adjacent to the fractured zones. $\mathrm{He}$ then arrived at an estimate of fracture porosity by subtracting values of matrix porosity from those of total porosity. His values of total fracture porosity ranged from 1 to 12 percent, and matrix porosity ranged from 1 to 6 percent. His laboratory values for matrix porosity ranged from 0.2 to 4.5 percent. For nine intervals ranging in length from 7 to 300 feet, he was able to calculate both total and matrix porosity. The average fracture porosity of those nine intervals ranged from 0 to 10 percent. These values excluded data for intervals that caved and for zones containing interbedded shale and carbonate strata. In general, the zones of highest fracture porosity calculated by Carroll for selected intervals in wells 88-66, 73-66, and 89-68 corresponded with the most permeable intervals in those holes. However, in other holes highly fractured zones, delineated by the sonic logs, yielded little or no water to the bore during drillstem tests.

The high fracture-porosity values estimated by Carroll do not necessarily contradict the considerably lower effective fracture porosity estimated from the cores. First, geophysical-log analysis cannot differentiate between the effective and noneffective porosity in the fractures filled with vuggy veinlets. Second, much of the total porosity detected by the density and neutron sondes may represent highly porous gouge fillings rather than void space. Third, and this is considered by Carroll (oral commun., Feb. 1, 1967) to be the major cause of the large differences in values of porosity, geophysical logging devices are inherently unable to measure accurately porosity differences of a few percent in rocks of extremely low porosity. Because of inhomogeneities in the formation and in the well bore, neutron, density, and sonic logging devices tend to register high porosity values for such rocks. Values thus obtained should be considered upper limits; in rocks with low porosities, the values may be in error by several hundred percent.

Drilling records do not indicate the penetration of any major caverns in the lower carbonate aquifer. By December 1966, approximately 16,000 feet of the lower carbonate aquifer had been penetrated in 26 holes drilled in 10 widely separated parts of the study area. Six thousand feet (about 37 percent) of this drilling was monitored at six drill sites by instruments that continuously recorded drilling rates. Two test holes, well 79-69a in southern Yucca Flat and well 65-62 in northeastern Amargosa Desert, each penetrated a single void about 2 feet long. The void in well 79-69a was reported by the driller, whereas that in well $65-62$ was recorded by instruments. The interval in well $65-62$ corresponded with a zone of lost circulation. Whether these voids are distal ends of solution caverns or fractures opened by solution cannot be determined.

The absence of major caverns is particularly significant because about 5,000 feet, or roughly 30 percent, of the total footage of carbonate rock drilled was penetrated at 13 drill sites beneath the Tertiary-preTertiary unconformity. Study of the Tertiary-preTertiary unconformity in outcrop also indicated the 
absence of any prominent solution alteration of the Paleozoic carbonate rocks beneath the unconformity.

Daily records of holes drilled with mud indicate that lost circulation commonly occurred during drilling of the carbonate rock aquifers. The rate of fluid loss generally changed abruptly with depth. The abruptness of the fluid loss, the absence of caverns, and the extremely low intercrystalline permeability of the rock suggests that the mud was lost into partly filled fractures. Conversely, in some holes drilled with air a sudden increase in water entry into the bore was noted occasionally. This marked entry of water probably indicates the penetration of the first major water-bearing fracture.

\section{DRILL-STEM AND PUMPING TESTS}

Hydraulic properties of the lower carbonate aquifer were measured by drill-stem and pumping tests of 10 wells. These wells were drilled to depths of 1,300 to 4,200 feet by the air-rotary or cable-tool method. In these wells, the lower carbonate aquifer was tapped at depths ranging from 735 to 1,500 feet below the surface to 3,700 to 4,206 feet below the surface. The construction record of each hole is presented by Thordarson, Young, and Winograd (1967).

Drill-stem tests were made in 8 of the 10 wells to identify intervals containing water-bearing fractures, to detect changes in head with depth, to pinpoint the source of water collected for chemical analysis, and to determine the capacity of the pump needed for the pumping test. The drill-stem testing techniques were primarily of two types - additive swabbing tests of open, (that is, uncased) holes and swabbing of select zones isolated by packers. However, oil field drill-stem tools of dual shutin type (described by Dolan and others, 1957, and by Ammann, 1960) were also used.

The drill-stem tests showed that the fracture transmissibility of the carbonate aquifer, as reflected by specific-capacity data, varies greatly with depth in each of the holes. Many straddle-packed intervals yielded only a fraction of a gallon per minute in response to a drawdown of hundreds of feet. Other intervals in the same hole were swabbed at a rate of $50 \mathrm{gpm}$ (gallons per minute) without lowering the water level more than a few feet.

None of the eight holes drill-stem tested showed a uniform pattern of increase or decrease in fracture transmissibility, and open fractures were present as much as 1,500 feet beneath the top of the aquifer and 4,200 feet below land surface. In some holes the transmissibility increased markedly with depth; in others the most permeable zones were near the top of the zone of saturation. In test well 88-66, for example, additive tests showed a negligible yield for the Pogonip Group in the interval of depth between 2,550 and 2,703 feet; yield increased about tenfold after penetration of the interval between 2,703 and 2,896 feet. Another tenfold increase in yield was measured after penetration of the interval between 3,095 and 3,295 feet (J. E. Moore and others, 1963). In test well 75-73, on the other hand, the only permeable zone of consequence in the Pogonip Group was in the interval between 1,217 and 1,448 feet; the top 105 feet and the bottom 405 feet of the saturated rock tapped apparently yielded little or no water to the bore.

The drill-stem tests of the three holes (73-66 in Rock Valley, and 88-66 and 87-62 in Yucca Flat) that penetrated the lower carbonate aquifer beneath the Tertiary-pre-Tertiary unconformity indicate negligible to moderate permeability immediately below the unconformity. In these holes the zones of greatest relative specific capacity are about 75,725 , and 240 feet, respectively, below the unconformity.

Three wells drilled into the aquifer in the Amargosa Desert, NW $1 / 4$ sec. 27, T. 16 S., R. 51 E., penetrated an aggregate thickness of about 560 feet of the lower carbonate aquifer. Flowmeter surveys made during injection of water into these wells indicated that the wells intersected only a few water-bearing fractures. Of equal interest, the survey of one hole indicated that a depth interval whose core contained open fractures several feet in length was nearly impermeable.

Pumping tests of 48 to 86 hours duration at constant discharge rates were made in each of the 10 wells penetrating the lower carbonate aquifer at Nevada Test site (table 3). Step-drawdown tests, at three different discharge rates, were made in four of the wells. At only one well site (79-69a) was a separate observation well (79-69) available in which to measure drawdown, and unfortunately, drawdown was not detected in the observation well because of extremely high transmissibility coupled with a moderate pumping rate.

Submersible-type pumps with a check valve immediately above the pump assembly and a second check valve several hundred feet above the first valve were used in all the wells. Water levels were measured with an electrical sonde in a 1-inch ID access line. Changes as little as 0.02 foot in water level are detectable with this instrument.

The semilog graphs of water-level drawdown and recovery for the pumping tests are characterized by a steep first limb and a gently sloping second limb (figs. 9-17), which make interpretation of hydraulic properties of the aquifer difficult. The steep initial limb usually lasts 10 to 60 minutes, gradually decreases in slope, and changes into the gentle limb, which generally persists for several hundred to more than 1,000 minutes. With increasing time, the gentle limb either continues declining (or rising during recovery), without detectable change in slope, or bends sharply downward (or upward during recovery). 


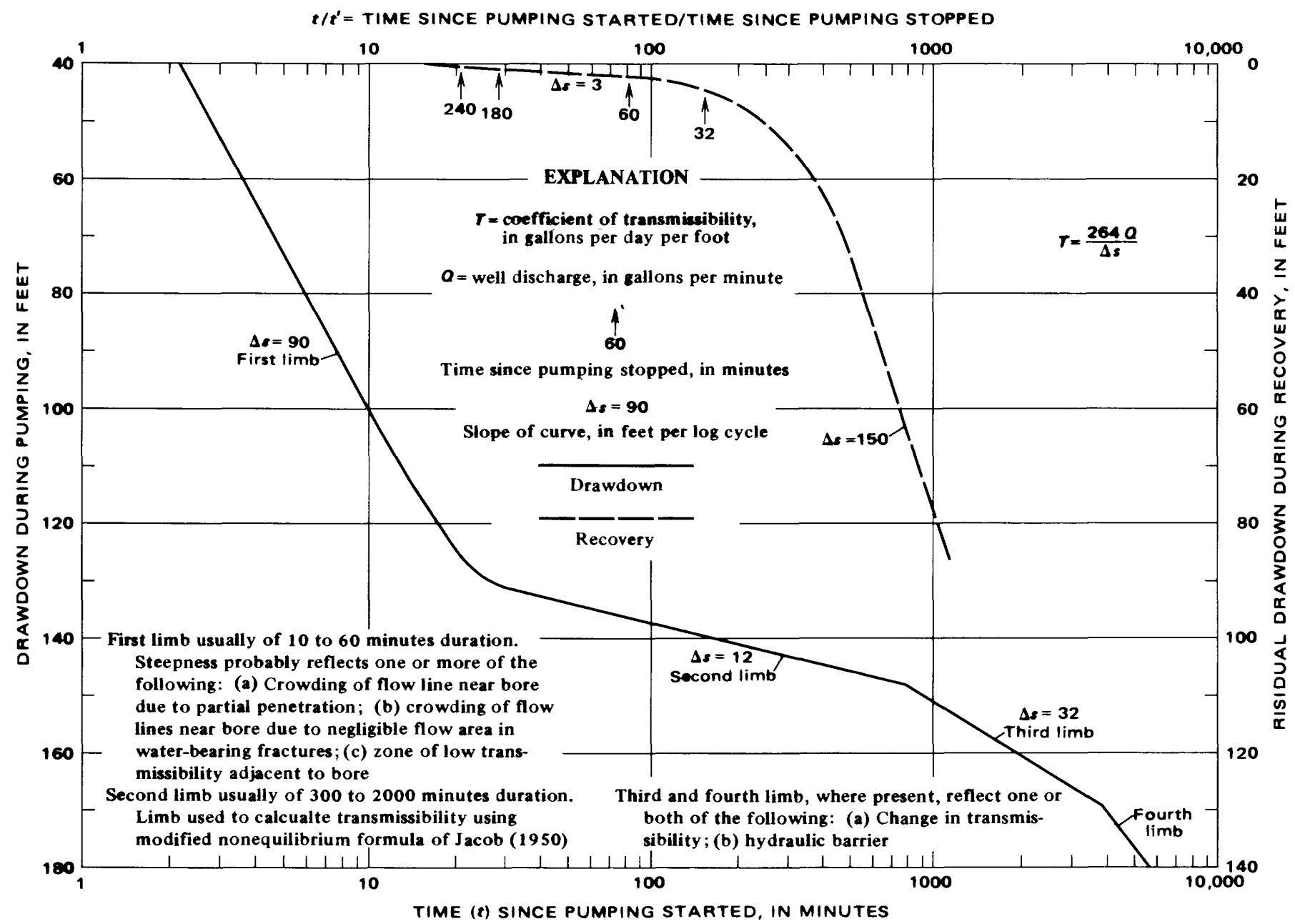

FIGURE 9. - Diagrammatic semilog graphs of water-level drawdown and recovery during single-well constant-rate pumping test in the lower carbonate aquifer.

The slope of the steep initial limb on the drawdown curves is about 5 to 20 times greater than that of the gentle secondary limb; on the recovery curves, the steep initial limb is about 10 to 60 times steeper than the second limb.

A second anomalous feature of the semilogarithmic curves is the rapid rate of recovery of water level after pumping. Theoretically, the recovery of water level at the conclusion of a pump test should take as much time as the drawdown. However, in each pumping test of the carbonate aquifers, the recovery was faster than the drawdown at equal times, particularly in the time interval 0 to 200 minutes. The more rapid rate of recovery results in an early limb that has a markedly steeper slope than the corresponding limb on the drawdown curve. Conversely, in every well the second, or gentle, limb of the recovery curve is gentler than the corresponding second limb on the drawdown curve. Similar anomalous recovery is also noticeable on semilog plots for a pump test of a fractured carbonate aquifer near Eureka, Nev. (Stuart, 1955, figs. 5 and 7).

Dual-limb semilog curves resembling those for the lower carbonate aquifer have been described in the ground-water and petroleum-reservoir engineering literature for the following flow geometries: (1) Leakage from an overlying or underlying semipervious confining layer; (2) a sloping water table; (3) an aquifer that thickens with distance from the well; (4) turbulence at the well face (Baker, 1955); (5) aquifer damage by drilling, the so-called skin effect; (6) partial penetration; and (7) a zone of below-average transmissibility adjacent to the bore. Only the last two flow geometries, plus a related condition, appear important during pump tests of the lower carbonate aquifer.

The configuration of the semilog curves is probably due to one or more of the following: (1) Threedimensional flow near the bore due to partial penetration of the aquifer; (2) a zone of reduced transmissibility, 
TABLE 3. - Pumping-test data for aquifers in Nevada Test Site and vicinity

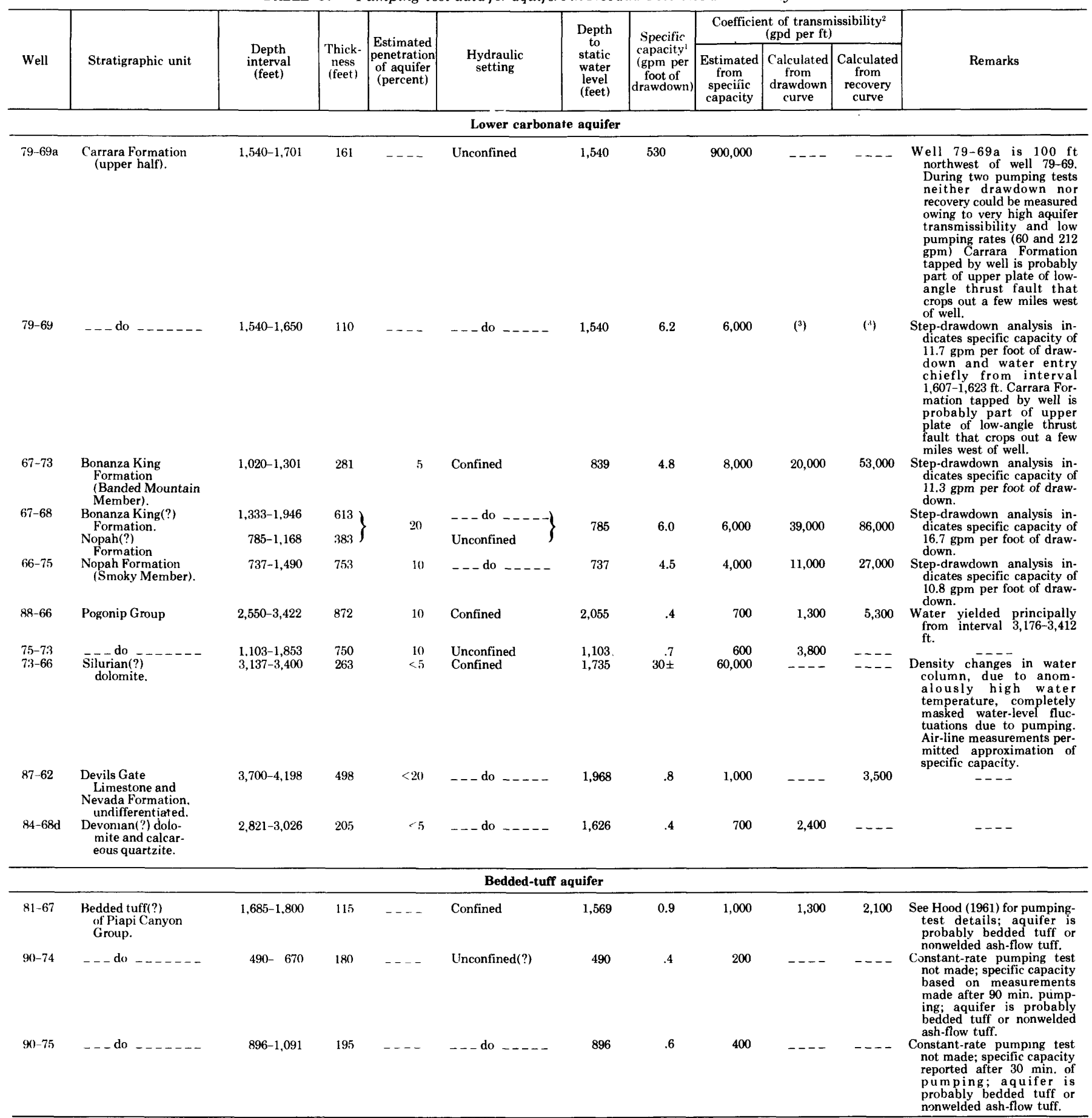

\begin{tabular}{|c|c|c|c|c|c|c|c|c|c|c|c|}
\hline \multicolumn{12}{|c|}{ Welded-tuff aquifer } \\
\hline $73-58$ & $\begin{array}{l}\text { Topopah Spring } \\
\text { Member of } \\
\text { Paintbrush Tuff. }\end{array}$ & $741-887$ & 146 & 40 & Confined(?) & 741 & 56 & 100,000 & $\begin{array}{l}\text { See re- } \\
\text { marks. }\end{array}$ & $\begin{array}{l}\text { See re- } \\
\text { marks. }\end{array}$ & $\begin{array}{l}\text { Drawdown of } 6.9 \mathrm{ft} \text { measured } \\
\text { with air line and test } \\
\text { pressure gage in first } 3 \text { min. } \\
\text { of pumping test at rate of } \\
387 \text { gpm; additional draw- } \\
\text { down not detectable in sub- } \\
\text { sequent } 57 \text { min. of pumping } \\
\text { test. }\end{array}$ \\
\hline $74-57$ & --- do ------ & $928-1.475$ & 547 & 100 & --- do ----- & 928 & 22 & 40,000 & 68,000 & $-\cdots$ & $\begin{array}{l}\text { Step-drawdown analysis } \\
\text { suggests considerable head } \\
\text { losses at face of bore; losses } \\
\text { are probably due to poor } \\
\text { gun perforation of casing. }\end{array}$ \\
\hline $81-69$ & --- do $\ldots \ldots \ldots$ & $1,507-1,675$ & 168 & 100 & $\ldots$ do $\ldots----$ & 1,507 & .1 & 200 & $\begin{array}{l}\text { See re- } \\
\text { marks. }\end{array}$ & 50 & $\begin{array}{l}\text { Well tested by bailing; data } \\
\text { on recovery of water level } \\
\text { given by Moore and Garber } \\
\text { (1962). }\end{array}$ \\
\hline
\end{tabular}


TABLE 3. - Pumping-test data for aquifers in Nevada Test Site and vicinity - Continued

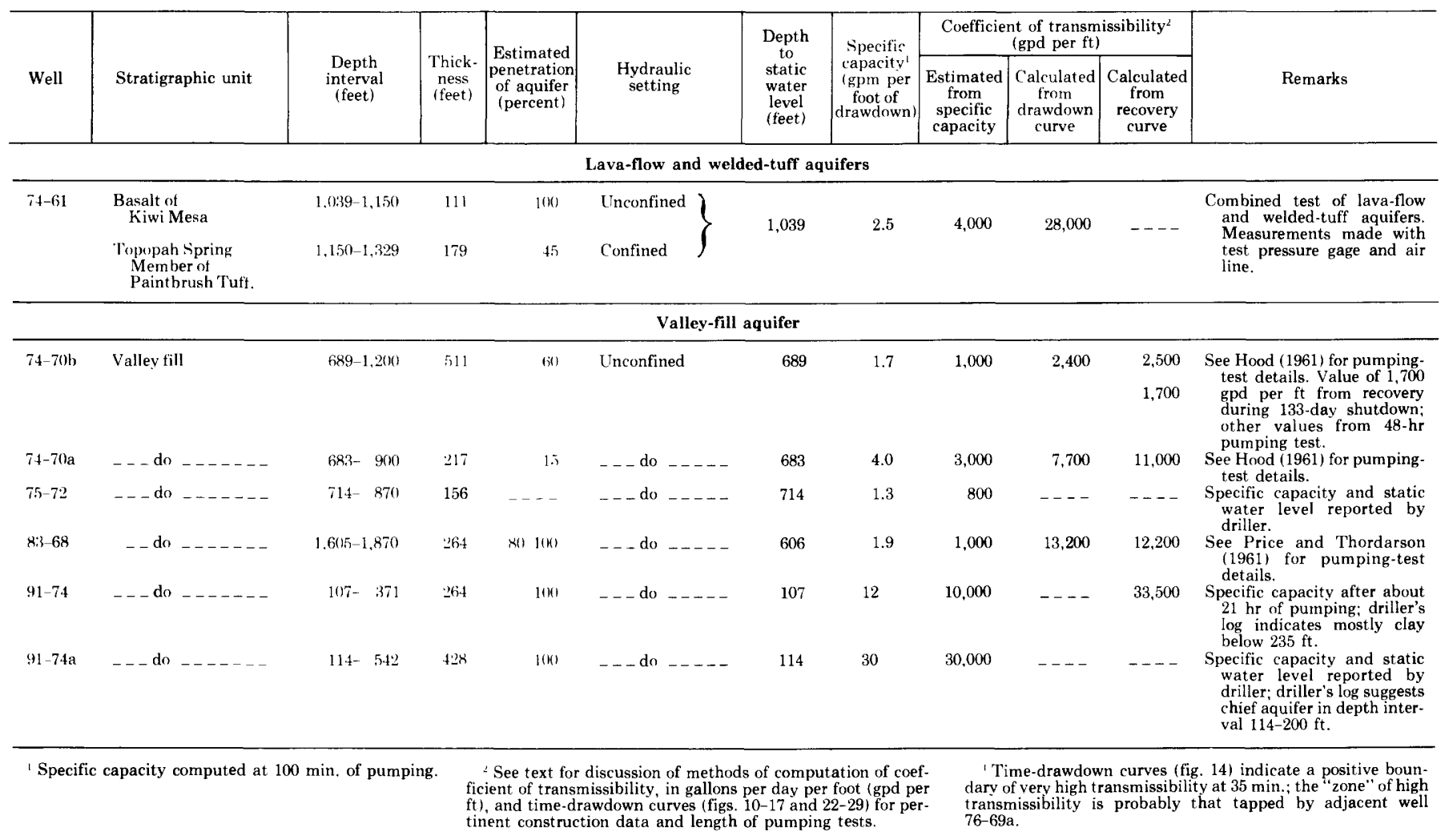

several tens to hundreds of feet thick, surrounding the bore; or (3) crowding of flow lines, within several tens to a few hundred feet of the bore, due to small crosssectional flow area in the water-bearing fractures tapped by the bore. Any of these three flow conditions would result in abnormally high time-dependent pressure losses near the bore, which would be reflected by the steep initial limb of the time-pressure curves.

Near a partially penetrating well, the flow lines converge on the bore not only radially but also spherically ; this convergence, or crowding, of the flow lines results in head losses that greatly exceed those for radial flow. For example, Muskat (1937, fig. 77) indicated that only 40 percent of the head loss of radial flow occurs within 5 feet of the bore, but as much as 95 percent of the head loss of spherical flow (near zero penetration) occurs within 5 feet; intermediate head losses (not illustrated by Muskat) occur for penetrations between 0 and 100 percent. Muskat's figure 77, when replotted on semilog paper, closely resembles the dual-limb time-pressure curves of the carbonate aquifer. The steep initial limb reflects the abnormal head losses near the bore, whereas the secondary limb reflects aquifer conditions farther from the bore, where flow is more nearly radial. A dimensionless semilog plot for partial penetration presented by Hantush (1964, fig. 11) also closely resembles the plots for the lower carbonate aquifer. Hantush's illustration indicates that after a certain time has elapsed, the slope of the gentle, or second limb of the curve approaches that for a fully penetrating well, except where well penetration is nearly zero. Time-pressure curves by Nisle (1958) for a partially penetrating well tapping a confined aquifer also closely resemble those for the lower carbonate aquifer. From Nisle's mathematical study he concluded that the standard modified nonequilibrium approach of Jacob (1950) could be used to compute aquifer transmissibility directly from the second limb of the curve. Nisle's study is of particular importance because the time-pressure curves he presented are for the pumped well, whereas Hantush's curves present time-pressure behavior for observation wells only. Geologic sections through each well test pumped at Nevada Test Site suggest that the wells penetrate 5 to 20 percent of the aquifer (table 3 ).

A zone of reduced transmissibility adjacent to the bore is a second possible cause for the dual-limb timepressure curves. Loucks and Guerrero (1961) presented many semilogarithmic curves showing the effect of varying the radius of a zone of reduced transmissibility and of changing the ratio of the transmissibility of the aquifer and of the zone adjacent to the bore. They assumed radial-flow geometry. Their curves closely resemble those for the lower carbonate aquifer. The steep initial limb of their curves reflects the low 


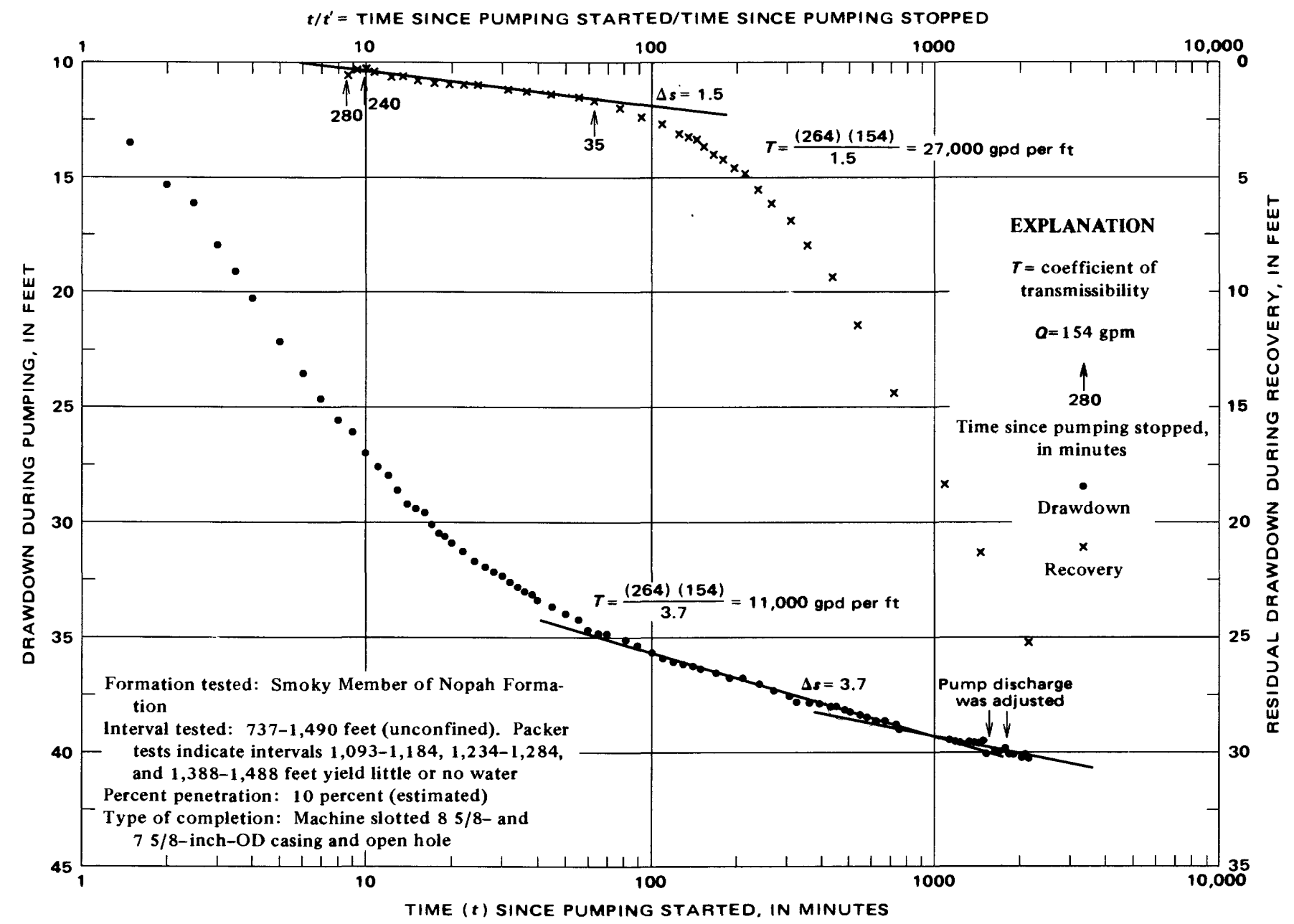

FIGURE 10. - Semilog graphs of drawdown and residual drawdown of water level during pumping test in test well 66-75, September $11-13,1962$.

transmissibility of the inner zone, whereas the gentle limb reflects that of the outer zone, the true formation transmissibility. The transition between the two limbs is gradual as it is in semilog curves for the lower carbonate aquifer. A zone of reduced transmissibility adjacent to some of the wells tapping the lower carbonate aquifer appears possible owing to the probable heterogeneity of the water-bearing fractures. However, the presence of such a zone adjacent to eight of nine wells in which drawdown was measurable seems unlikely.

A third possible cause for the abnormally high head losses shown by the first 60 minutes of the time-pressure data is the very small cross-sectional flow area in the water-bearing fractures near, and tapped by the bore. Within several tens to a few hundred feet of the bore, the flow lines may converge toward a single fracture or perhaps toward a few fractures that connect with the bore; the resulting head losses may therefore be considerably greater than those near a hole tapping an aquifer producing from interstices. These head losses are hereafter called head losses due to ramming, or ramming effect, to emphasize the physical crowding of the flow lines in the fractures near the wells. Head losses due to the postulated ramming effect are expectable in most wells tapping the lower carbonate aquifer.

The relative importance of partial penetration, a zone of reduced transmissibility, or the ramming effect on the pressure losses near each well site cannot be determined with available data. At some sites, all three factors may be operative. For example, the head losses that result from a zone of reduced transmissibility and from the ramming effect should apply not only to radial flow toward a fully penetrating well but also to threedimensional flow toward a partially penetrating well. Of the three flow geometries, partial penetration probably occurs at each well site. Ramming effect also probably occurs at most well sites owing to the small crosssectional flow area in the water-bearing fractures. Par- 


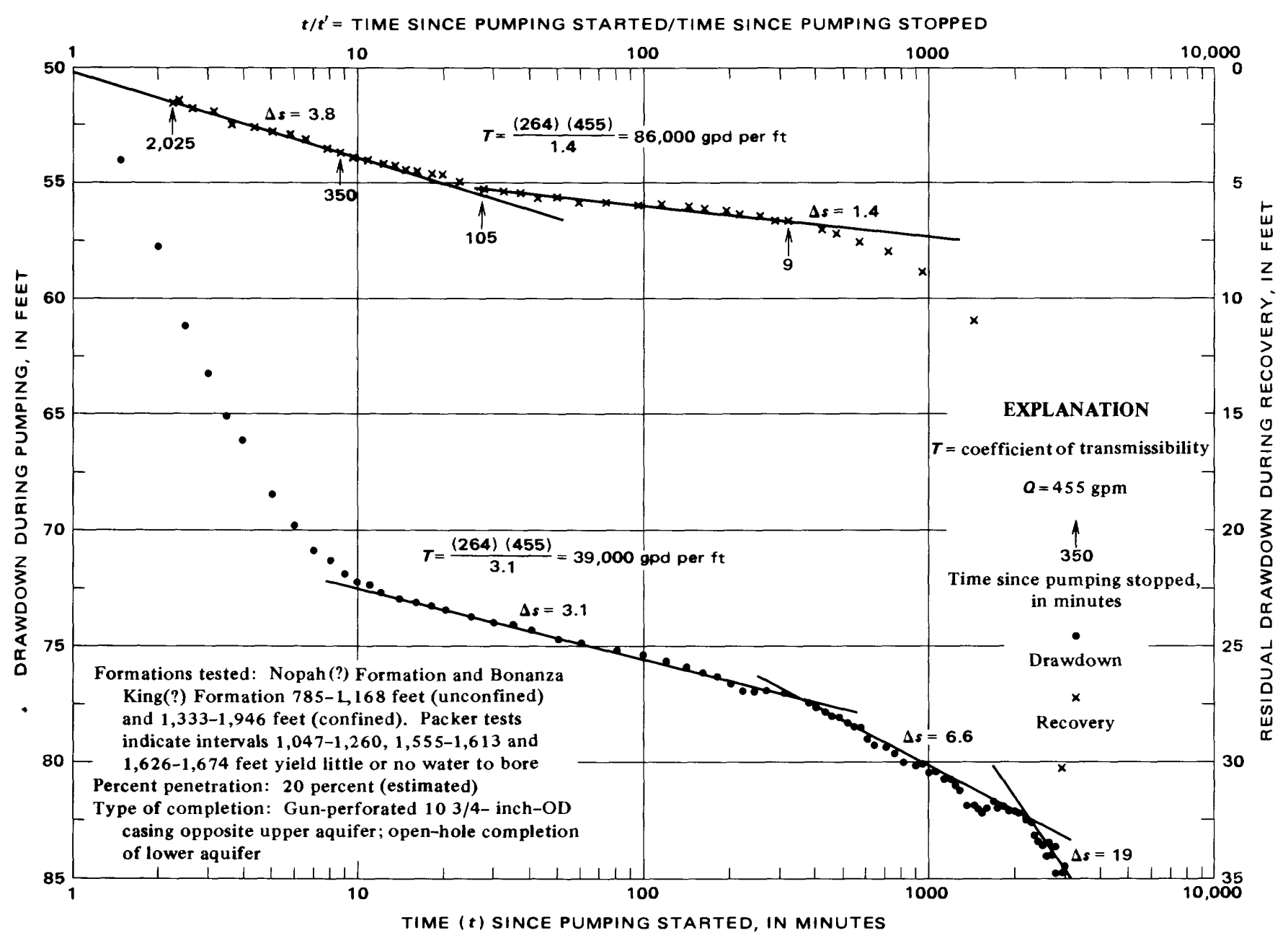

FIGURE 11. - Semilog graphs of drawdown and residual drawdown of water level during pumping test in well 67-68, September 11-14; 1962.

tial penetration and ramming appear chiefly responsible for the steep initial limb of the time-pressure curves. Whatever the exact cause of the steep initial limb, the gentle second limb represents aquifer conditions at a greater distance from the bore than that represented by the steep limb.

The authors cannot explain the abnormally rapid recovery rate, nor did they find an applicable explanation in the literature. The anomalous recovery rate does not appear to be due to the entry of lower density water into the well during the pumping period. Such a density decrease, which would result in a water column longer at the end than at the start of pumping, could be due to warming of the water column during pumping and (or) to entry of gas into the water column. Differences in ambient water temperature between the top and bottom of the water column in wells at the test site have been measured and are as much as $35^{\circ} \mathrm{F}$, though they are usually less than $20^{\circ} \mathrm{F}$. Such temperature differences, when coupled with water-column lengths of $500-1,400$ feet, are probably responsible for post-pumping static water levels which were higher than pre-pumping levels in wells 84-68d and 88-66 (Moore and others, 1963, table 6; D. B. Grove, written commun., Oct. 1, 1967). However, temperature changes alone cannot explain the rapid recovery of water level, which in some wells (84-68d and 88-66, figs. 15 and 17) was as much as 40 feet greater than drawdown at comparable times. Some mechanism other than temperature-induced density changes must be operating. Outgassing has not been noted in the sampled waters. Until the significance of the anomalous recovery rate is understood, the authors elect not to utilize transmissibility values obtained from the recovery curves.

The constant slope of the second limb of the semilog curves (figs. 10-17) suggests that the fracture transmissibility of the lower carbonate aquifer may be homogeneous on a gross scale even if locally nonhomogeneous. Within the time interval (as much as $2,000 \mathrm{~min}$.) represented by the gentle limb, no promi- 


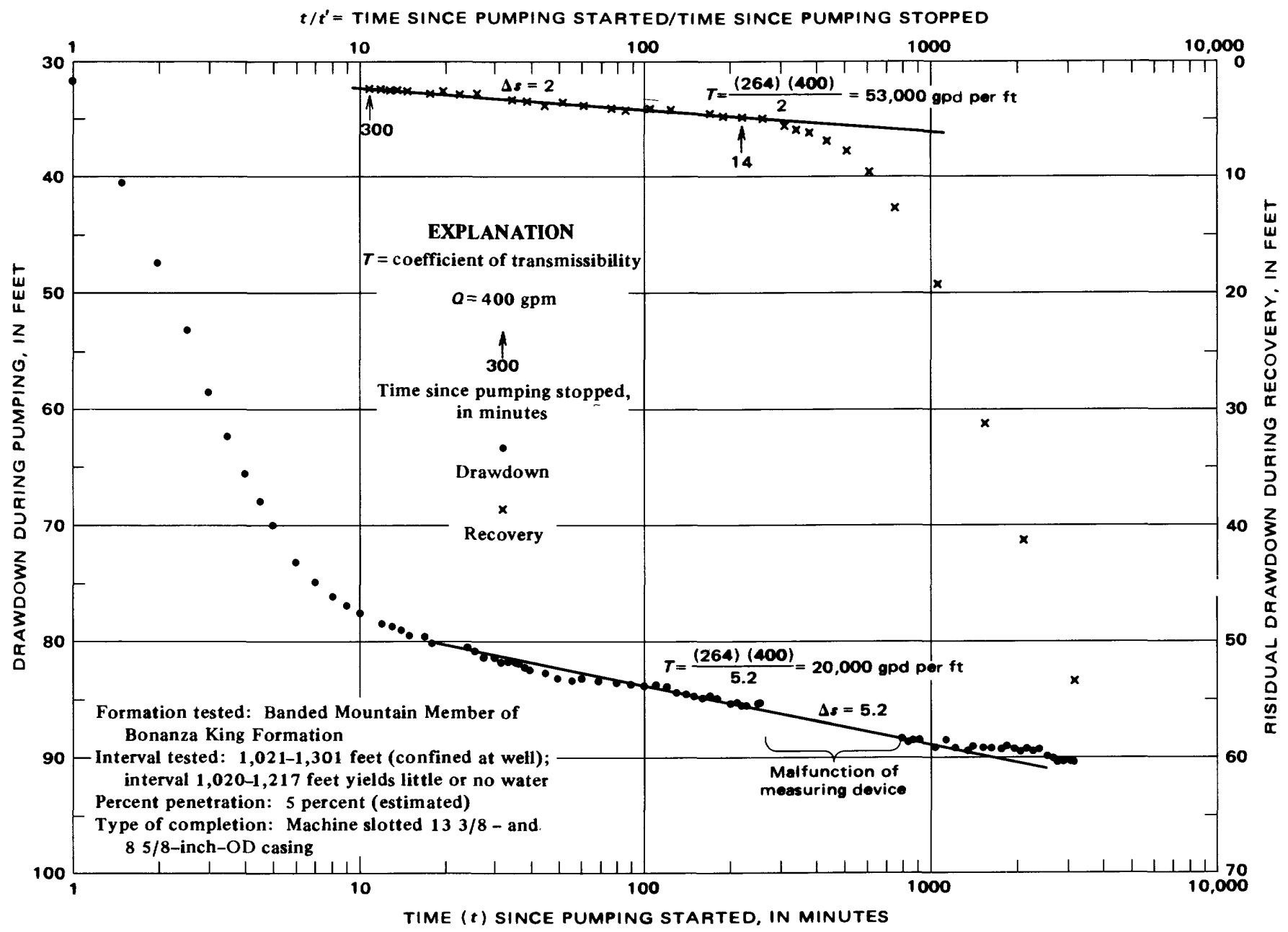

FIGURE 12. - Semilog graphs of drawdown and residual drawdown of water level during pumping test in well 67-73, February 24-26, 1963.

nent changes in slope could be detected even on expanded-scale plots of the time pressure data shown in figures 10-17. The absence of such breaks in slope may suggest that the water-bearing fractures are reasonably well connected and that fractures of differing transmissibility, if present, are randomly distributed. Or, stated differently, after a large volume of aquifer is sampled by pumping, the areas of low fracture transmissibility that may have been intersected are apparently balanced by regions of high transmissibility; the resultant time-pressure curve resembles that of a grossly homogeneous aquifer. That this often cited qualitative explanation is experimentally sound was proven through model studies of fractured aquifers by Warren and Price (1961) and Parsons (1966).

The work of Nisle (1958) indicates that transmissibility of partially penetrated and confined isotropic aquifers can be determined by applying the slope of the second limb of the time-pressure curves to the modified nonequilibrium formula of Jacob (1950).
The coefficients of transmissibility calculated using the modified nonequilibrium formula are listed in table 3 . To estimate the coefficients of transmissibility of four wells having no clearly defined drawdown curves, specific-capacity data were applied to a conversion chart relating these two parameters (Walton, 1962, fig. 4).

The coefficients of transmissibility derived from the drawdown curves of six wells range from 1,300 to 39,000 gpd per $\mathrm{ft}$. Their median value is about 7,000 gpd per $\mathrm{ft}$, and their mean value is $13,000 \mathrm{gpd}$ per $\mathrm{ft}$. The coefficients of transmissibility derived from the secondary limb of the recovery curves range from 1.7 to 2.5 times those computed from the drawdown curve (table 3 ). The difference is due to the anomalous recovery rate cited earlier. These values are considered inaccurate.

Coefficients of transmissibility estimated from the specific-capacity data of 10 wells range from 600 to $900,000 \mathrm{gpd}$ per $\mathrm{ft}$. Their median value is $5,000 \mathrm{gpd}$ per $\mathrm{ft}$, and their mean value is about $100,000 \mathrm{gpd}$ per $\mathrm{ft}$. The mean value is strongly influenced by the very large 


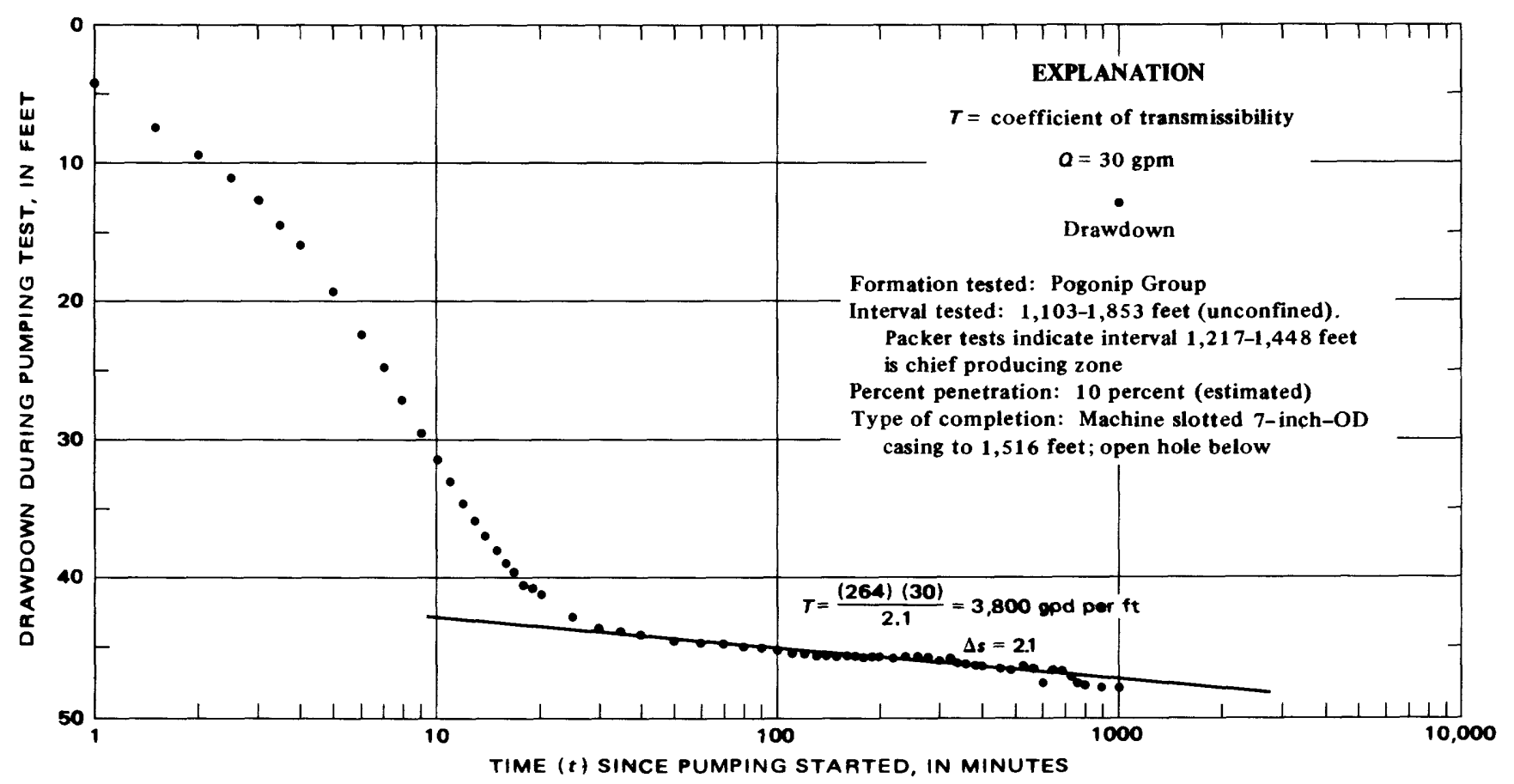

FIGURE 13. - Semilog graph of drawdown of water level during pumping test in test well 75-73 (Frenchman), May 9, 1962.

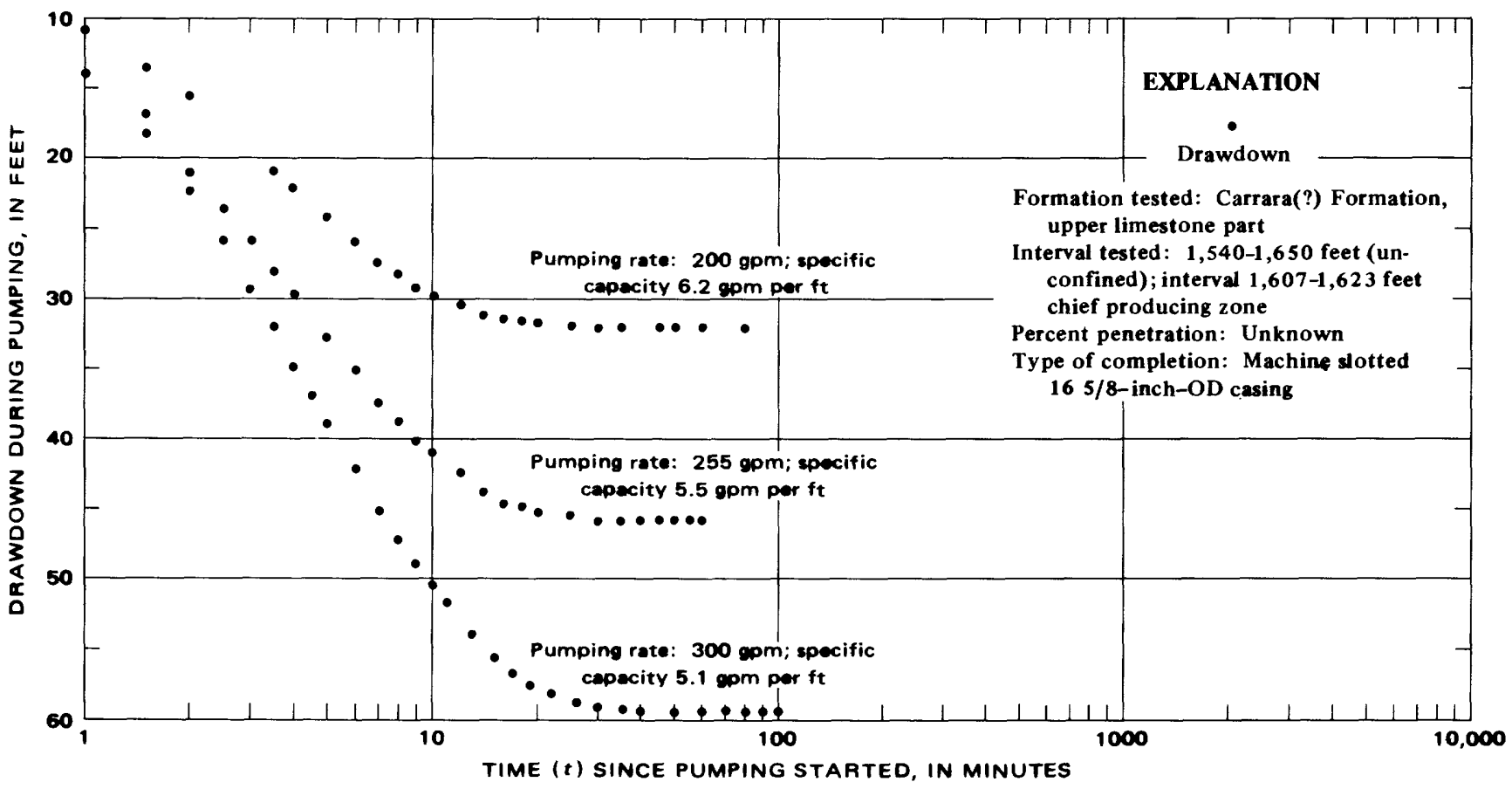

FIGURE 14. - Semilog graphs of drawdown of water level for three different rates of pumping in well 79-69.

specific capacity of a single well (79-69a). The magnitude of error in estimating coefficients of transmissibility from specific capacity is shown by the data of table 3 . Nevertheless, in the absence of draw- down curves for four of the wells (table 3), such a value is useful to obtain minimum values of transmissibility. For the six wells with clearly defined drawdown curves, the coefficients of transmissibility estimated from the 
$t / t^{\prime}=$ TIME SINCE PUMPING STARTED/TIME SINCE PUMPING STOPPED

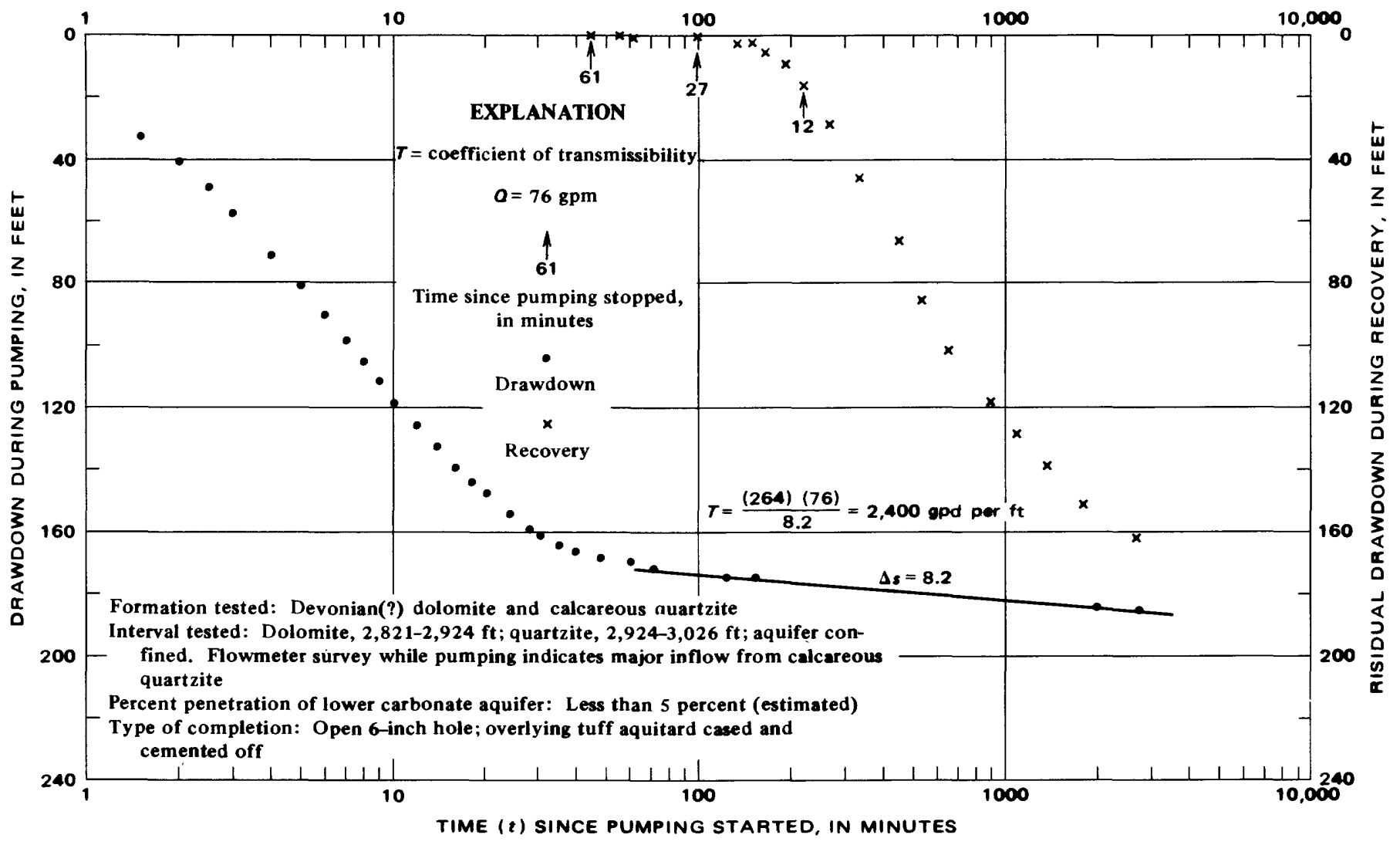

FIGURE 15. - Semilog graphs of drawdown and residual drawdown of water level during pumping test in test well 84-68d, November 21-23, 1966.

specific capacity data are about $1 / 6$ to $1 / 2$ of the values derived from the second limb of the drawdown curve (table 3).

That the wide range in transmissibility (table 3) need not be randomly distributed areally but rather is structurally controlled is suggested by the tests of wells 79-69 and 79-69a in southern Yucca Flat and of three wells drilled in northwestern Amargosa Desert (in NW $1 / 4$ sec. 27, T. 16 S., R. 51 E.). These five wells tap the lower carbonate aquifer in the upper plate of low-angle thrust faults. Specific-capacity data for these wells suggests minimum coefficients of transmissibilities that range from 25,000 to $900,000 \mathrm{gpd}$ per $\mathrm{ft}$. The transmissibilities of these wells probably reflect the intense fracturing and disaggregation common to thin thrust plates in outcrop and shown by the cores from these wells. These two groups of wells also suggest that the lithology of the aquifer (dolomite versus limestone), at least locally, is subordinate to structure as a control on transmissibility. Wells 79-69 and 79-69a tap limestone strata of the Carrara Formation in the upper plate of a thrust fault. But at the Amargosa Desert well sites, the limestone of the Carrara Formation occurs only in the lower plate of the thrust; the Bonanza King Formation occurs in the upper plate. The major fracture transmissibility exists in the dolomite strata of the Bonanza King Formation. Of the wells listed in table 3 (except wells 79-69 and 79-69a), six tap dolomite, dolomite and limestone, or dolomite and quartzite, and only two tap limestone; hence, no relationship of transmissibility to lithology can be drawn from these well data.

No attempt was made to determine the storage coefficient of the lower carbonate aquifer from the pump-test data. Such a determination is of questionable value even when obtained from a fully penetrating pumped well (Ferris, 1959). However, core examination suggests that the effective fracture porosity of the lower carbonate aquifer is probably a fraction of 1 percent; accordingly, the storage coefficient under unconfined conditions is not likely to exceed 0.01 . Because of the extremely low effective porosity of the carbonate rocks, the specific storage under confined conditions is governed by the bulk modulus of compression of the rock and probably ranges between $10^{-5}$ and $10^{-6}$ per foot. On the other hand, where the aquifer is several thousand feet thick the storage coefficient may be as large as $10^{-3}$. 


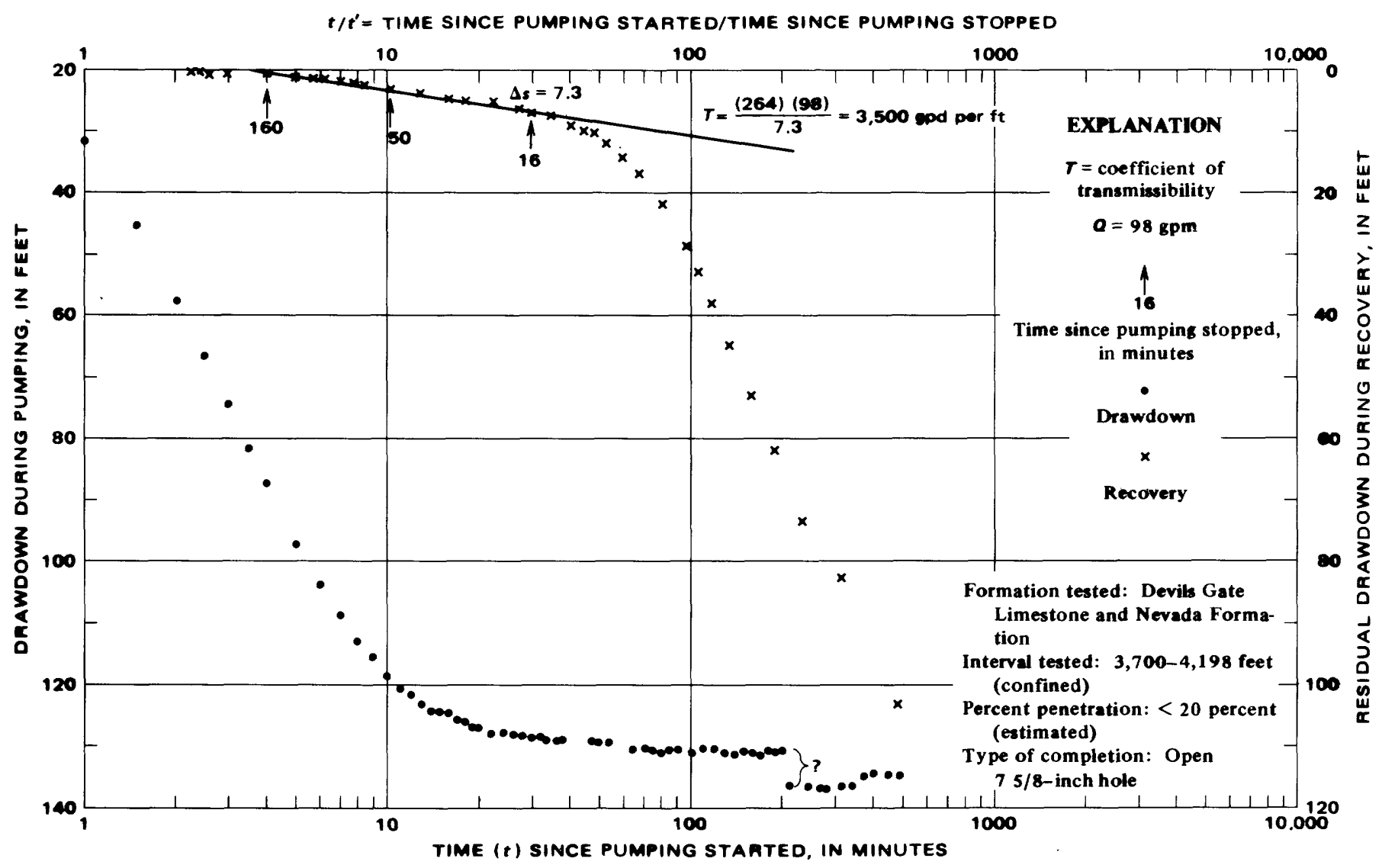

FIGURE 16. - Semilog graphs of drawdown and residual drawdown of water level luring pumping test in test well 87-62, August 10-11, 1962.

Two additional features of the semilog curves of the pump-test data warrant brief mention. The semilog curves of five wells (wells 67-68, 67-73, 75-73, 84-68d, and 88-66) exhibit a third or fourth limb in addition to the steep initial limb and the gentle secondary limb. (For some of these wells the additional limbs are discernible only on expanded-scale plots of figs. 10-17). These limbs, where present, have a steeper slope than the second limb. This condition suggests a lateral change in aquifer character. The steeper limbs reflect a reduction in aquifer transmissibility, which may be due to one or more of the following: (1) A hydraulic discontinuity within the aquifer, which may reflect either termination of the aquifer along a major fault or the presence within the aquifer of a gouge-lined fault zone; (2) thinning of the aquifer near structural highs; and (3) a lateral decrease in fracture transmissibility unrelated to aquifer thickness. Whatever the cause, these limbs, in contrast to the second, suggest a marked decrease in aquifer transmissibility. Similar limbs are shown by Stuart (1955, figs. 5, 9, and 11) for tests of Paleozoic carbonate rocks near Eureka, Nev.

Evidence that fault zones, rather than solutionwidened joints, are locally the principal water-bearing fractures in the lower carbonate aquifer is suggested by the pump test of one well in the study area and by a pump test of the Fad shaft in the Eureka mining district, Eureka County, Nev. The air-rotary method was used to drill well 67-68 through the Nopah(?) Formation (saturated in the depth interval 785 to $1,168 \mathrm{ft}$ below land surface). Though the bore penetrated no caverns and no mud was used to drill this part of the hole, water pumped from the hole during the first tens of minutes of the first of a series of pump tests was muddy. In addition, the specific capacity of this well (not the transmissibility) increased during later pumping tests. Both the muddy water and the increase in specific capacity are probably due to the washing out of gouge from a fault zone rather than to the production of water from a joint. A similar discoloration of water and attendant increase in specific capacity was reported by Stuart (1955) during a pumping of the Fad shaft after penetration of a fault zone in a drift 2,250 feet below land surface; other faults in the same mining district appear to be barriers, however (Nolan, 1962, p. 57-61).

In summary, the drill-stem and pumping tests yielded the following significant information on the lower carbonate aquifer: 


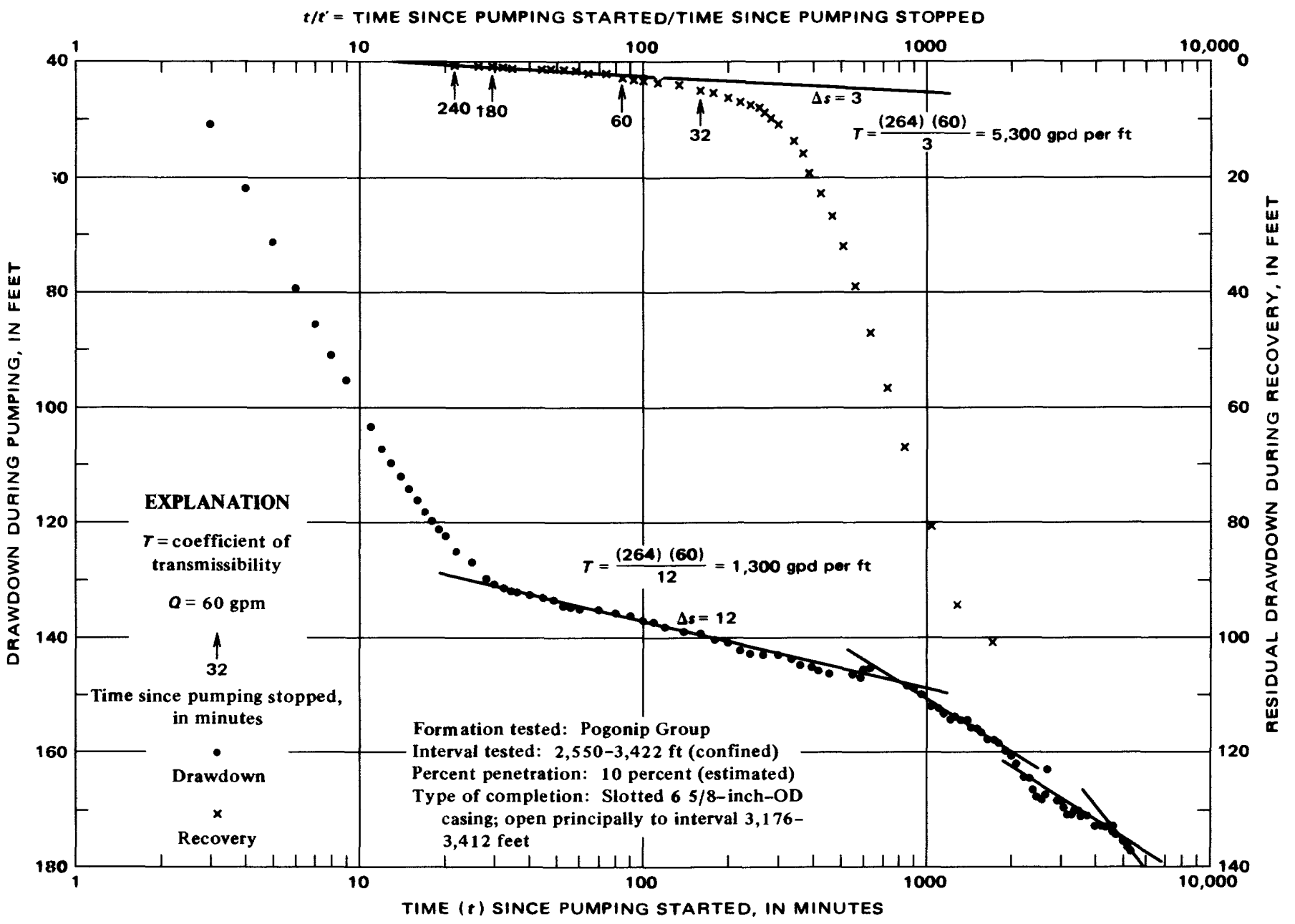

FIGURE 17. - Semilog graphs of drawdown and residual drawdown of water level during pumping test in well 88-66, March 16-20, 1962.

1. Water-bearing fractures are sparse, but they are open to depths of at least 1,500 feet beneath the top of the aquifer and up to 4,200 feet below land surface. There is no apparent decrease in fracture yield to this depth.

2. Transmissibility of the carbonate aquifer beneath the Tertiary-pre-Tertiary unconformity is not above average.

3. The coefficient of transmissibility of the aquifer ranges from about 1,000 to 900,000 gpd per ft.

4. Eight of 12 pumping tests (including four made at Eureka, Nev.) indicate that the aquifer is cut by one or more negative hydraulic boundaries.

\section{UPPER CARBONATE AQUIFER}

The Tippipah Limestone of Pennsylvanian and Permian age is the upper carbonate aquifer of this report (table 1). It is 3,600 feet thick, but it has been eroded from most of the study area. The upper carbonate aquifer is saturated only beneath the western one-third of Yucca Flat at altitudes below 3,800 feet; elsewhere in the study area these carbonate rocks are absent beneath the valleys or occur in ridges well above the regional water table. In western Yucca Flat the upper carbonate aquifer is separated from the lower carbonate aquifer by as much as 8,000 feet of the upper clastic aquitard, the Eleana Formation.

Carbonate rocks equivalent, in part, to the Tippipah Limestone occur within the zone of saturation at and near the village of Indian Springs in southern Indian Springs Valley. These rocks (Bird Spring Formation) are tentatively considered to be part of the lower carbonate aquifer, despite their stratigraphic position, because the strata equivalent to the Eleana Formation are very thin in this area and are principally of carbonate lithology. The term "upper carbonate aquifer" is restricted to Yucca Flat.

As of December 1966, no hydraulic tests had been made of this aquifer. However, outcrop examination and exploration by shallow core holes indicate that its water- 
bearing character is probably similar to that described for the lower carbonate aquifer.

The upper carbonate aquifer, though of limited potential value as a source of water supply for part of western Yucca Flat, does not play a role in the regional movement of ground water beneath Nevada Test Site because its saturated extent beneath the regional water table is restricted to small areas.

\section{WELDED-TUFF AQUIFER}

The welded-tuff aquifer includes the Topopah Spring and Tiva Canyon Members of the Paintbrush Tuff and the Rainier Mesa and Ammonia Tanks Members of the Timber Mountain Tuff (table 1). The Paintbrush Tuff and the Timber Mountain Tuff compose the Piapi Canyon Group defined by Orkild (1965). Only the Topopah Spring Member has been tapped by wells within the zone of saturation. As of December 1966, this tuff was the sole aquifer used for water supply in Jackass Flats.

The welded-tuff aquifer occurs throughout much of the Nevada Test Site, but it is a potential source of water supply only in the structurally deepest part of the intermontane basins, where it occurs within the zone of saturation.

\section{CHARACTER IN OUTCROP}

Physical characteristics of ash-flow tuffs that could affect the movement of ground water include jointing, relation of joint density to degree of welding, horizontal partings within the flows, nature of the basal and the upper parts of the flows, and vertical variation of interstitial porosity and permeability within a flow. These characteristics are largely a result of the mode of origin of the ash-flow tuffs. The general discussion of the origin of these rocks and the terminology used were extracted from the works of Ross and Smith (1961) and Smith (1960).

Ash-flow tuffs are the consolidated deposits of volcanic ash emplaced through flowage of a turbulent mixture of gas and pyroclastic materials. The deposits consist principally of glass shards and pumice fragments usually less than 0.15 inch in size, although some flows consist of ejecta of coarser size. The deposits are characteristically nonsorted and exhibit no bedding; this characteristic contrasts with the generally pronounced bedding of ash-fall tuff deposits. Some ash flows are only a few feet thick, but in general they are tens, and some are hundreds, of feet thick.

After emplacement of an ash flow, compaction or welding of the ash may result in an average 50-percent reduction in porosity of the original flow. Welding is defined as the process that promotes the union or cohesion of the molten glassy shards and pumice.

Welding within a single ash flow is variable. Smith (1960) distinguished three zones of variable thickness in most ash flows: the zone of no welding, the zone of partial (or incipient) welding, and the zone of dense welding. The zone of dense welding is commonly underlain and overlain by zones of partial welding, which are sandwiched between zones of no welding. In some thin flows that were exceptionally hot, the entire unit of tuff may be densely welded; in others, welding may be absent or minor.

The degree of welding directly affects the interstitial porosity of the ash-flow tuff. Measurements reported by Ross and Smith (1961) for ash-flow tuff in central New Mexico show an inverse relation between degree of welding and porosity. In the nonwelded base or top of a fresh ash flow, the interstitial porosity may be greater than 50 percent; in the densely welded part, it may be less than 5 percent (fig. 18).

Columnar jointing characterizes the zones of dense and of partial welding; these joints form in response to tensional forces active during cooling of the flow (figs. 18-20). The columnar-joint spacings range from a few tenths of an inch to many feet; the more closely spaced joints are usually in the zone of most intense welding. The joints are usually vertical, but departures from the vertical are not rare. Cooling joints are uncommon in the nonwelded parts of the ash flow (fig. 20).

Reduction in porosity that accompanies welding also results in a prominent foliation within the rock. Pumice fragments, randomly oriented in the nonwelded zone, are flattened and subparallel in the zone of partial welding. Transition from the zone of partial welding to the zone of dense welding is marked by further flattening of the pumice fragments and a marked reduction of their porosity. Foliation is probably responsible in part for nurizontal partings commonly seen within zones of dense welding in outcrop. These partings parallel the dip of the ash flow and can be mistaken for bedding planes. The partings may also mark the contact of adjacent flows in a multiple-flow simple cooling unit.

The basal contact between the ash-flow tuffs and the underlying strata (bedded tuff) is generally gradational, but locally the flows incorporate rubble from the underlying terrain. Ross and Smith (1961) mentioned that rubble is common near the base, but it may occur well up in the flow and give an impression of being bedding (fig. 18).

Gases within the densely and partially welded zones form cavities (lithophysae) that are roughly circular, may be partly lined with primary and secondary minerals, and are as much as 1 inch in diameter (fig. 21). Cavities formed within flattened pumice fragments are also common (fig. 19); these hollows (miarolitic cavities) may not be gas cavities but rather large pumice fragments that have been altered by vapor-phase crystallization and weathering. Locally, both types of 


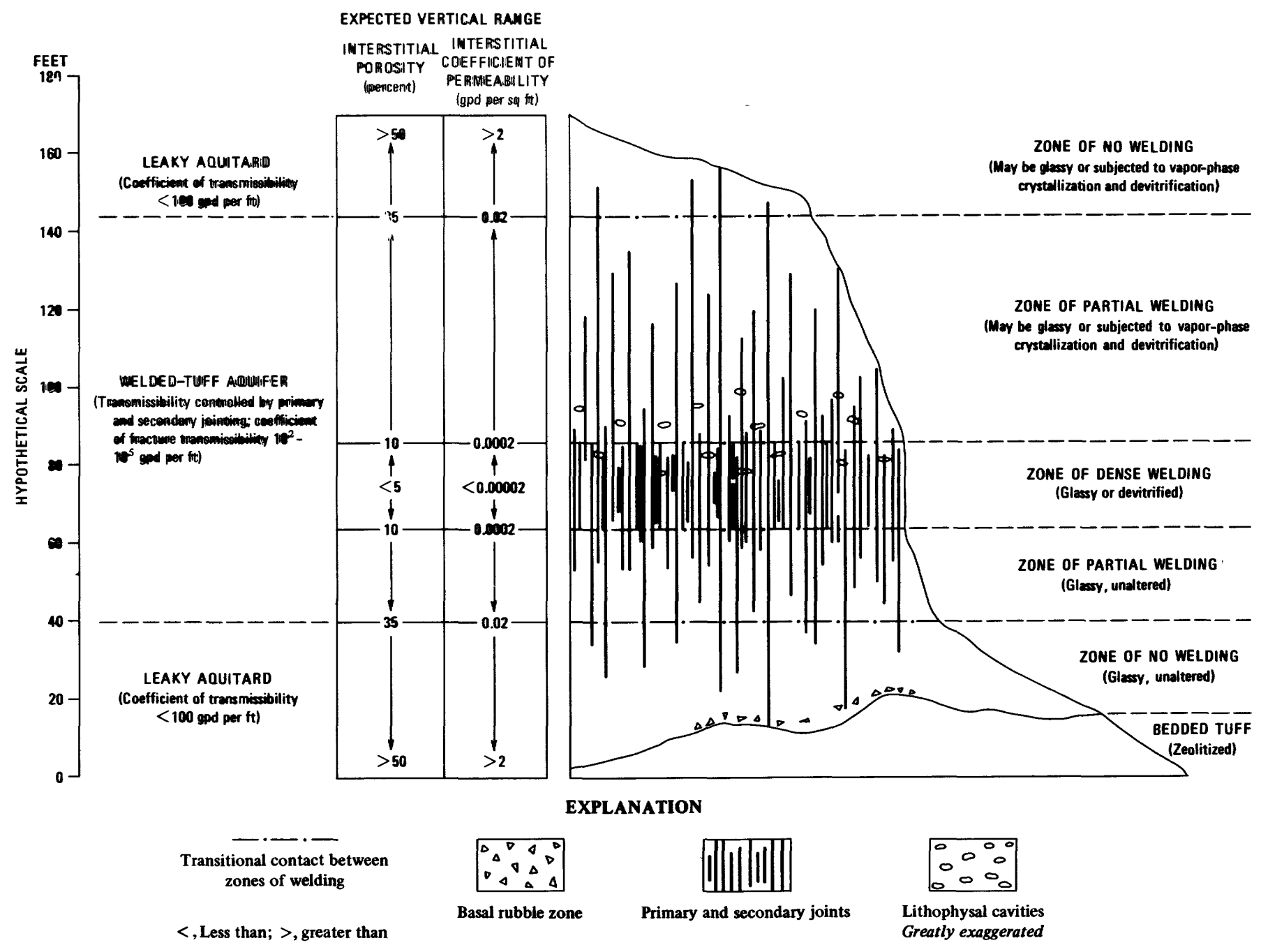

FIGURE 18. - Diagrammatic section of ash-flow tuff, showing relation of joint density, interstitial porosity, coefficient of interstitial permeability, and coefficient of fracture transmissibility to degree of welding. Simple cooling unit illustrated; in multiple-flow compound cooling unit, two or more zones of dense welding may be present.

cavities together may constitute as much as 10 percent of the volume of a welded tuff.

An ash-flow tuff may consist of a single emplacement of ash, multiple emplacements that were deposited in rapid succession and were cooled as a unit, or multiple emplacements that were not deposited in rapid succession. A flow consisting of a single emplacement or of multiple emplacements that cooled together is called a simple cooling unit (Smith, 1960). Units emplaced at time intervals whose duration precluded uniform cooling are called compound cooling units (Smith, 1960). This distinction is important hydrologically, because fractures play an important role in the movement of ground water through ash-flow tuffs. In the simple cooling unit, for example, only a single densely welded fractured zone is commonly present; whereas in a compound cooling unit, two or three such zones may be present.
The preceding paragraphs described, in general terms, the origin of ash-flow tuffs and their principal primary and secondary features as outlined in current literature. Similar features of the ash-flow tuffs at the Nevada Test Site are described below with reference to their waterbearing character.

The joints in outcrop in the ash-flow tuffs of the Piapi Canyon Group are polygonal cooling joints and secondary joints caused by later forces such as compaction of the underlying porous bedded tuff or regional stresses. Both types of joints are largely restricted to the dense brittle welded tuff and die out or markedly decrease in frequency within the underlying and overlying partly welded zone (fig. 20). The spacing of the cooling joints ranges from a fraction of an inch in the glassy densely welded zones to a few feet in the zone of partial welding; the nonwelded zone contains few visible joints. The 


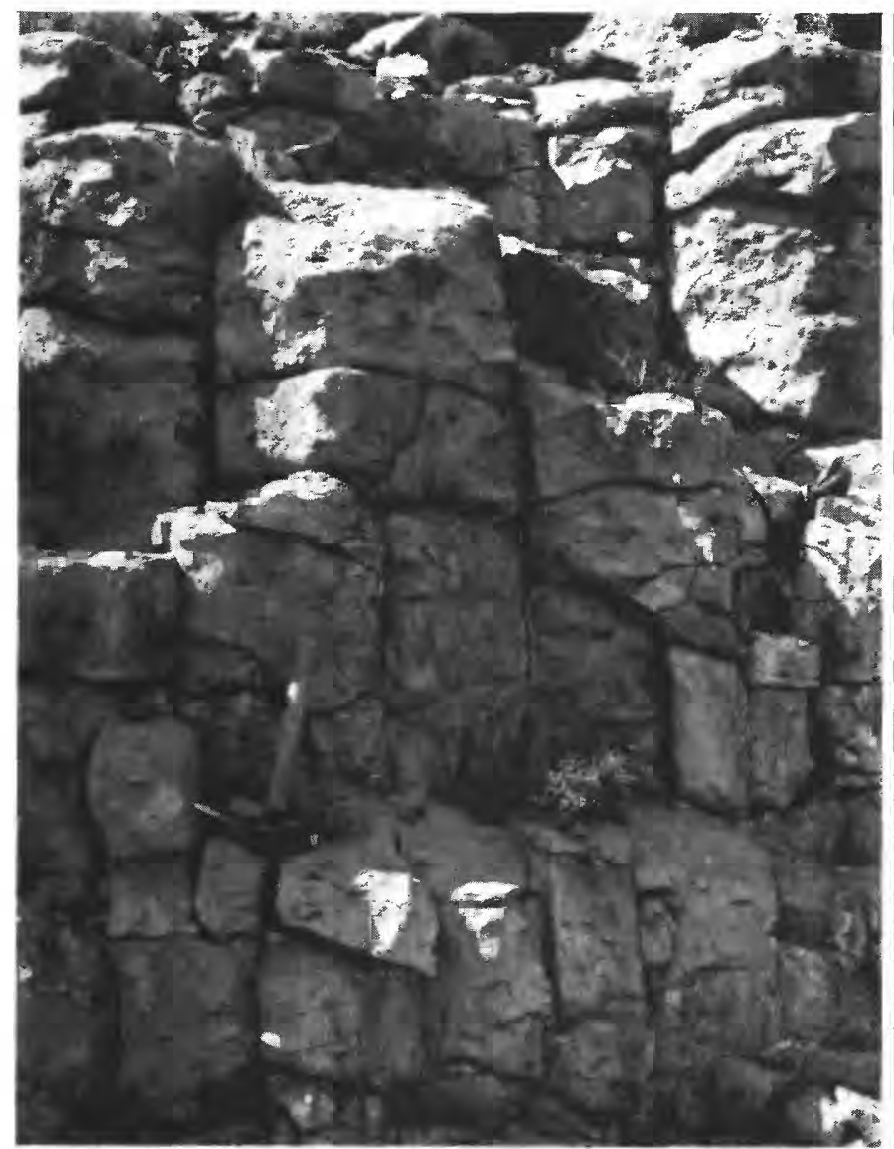

FIgURE 19. - Columnar jointing in ash-flow tuff, Tiva Canyon Member of Paintbrush Tuff, at Busted Butte, western Jackass Flats. Foliation marked by eroded pumice.

polygonal structure is generally obscured by secondary jointing, except in the youngest welded tuffs. Most of the primary and secondary joints dip $70^{\circ}$ to vertically. The strike of the secondary joints is highly variable, but the dominant strike parallels that of the major normal faults. Most of the joints in outcrop were tightly closed.

The interstitial porosity in the ash-flow tuffs of the Piapi Canyon Group is inversely related to the degree of welding (fig. 18). No interstitial porosity was visible (with hand lens) in the densely welded tuff, and very little was visible in the partially welded tuff.

Lithophysae, much like the vesicles in basalt, are usually unconnected or poorly connected.

Rubble zones at the base of ash-flow tuffs, in contrast to rubble zones beneath some basalt flows, are not highly permeable. The rubble in outcrop is completely surrounded by and incorporated into the ash-flow material. Hence, permeability of the rubble zone is controlled by that of the ash matrix.

The horizontal partings are locally a few tenths of an inch wide and tens of feet long. Because the partings parallel the foliation within the welded zone or the con-

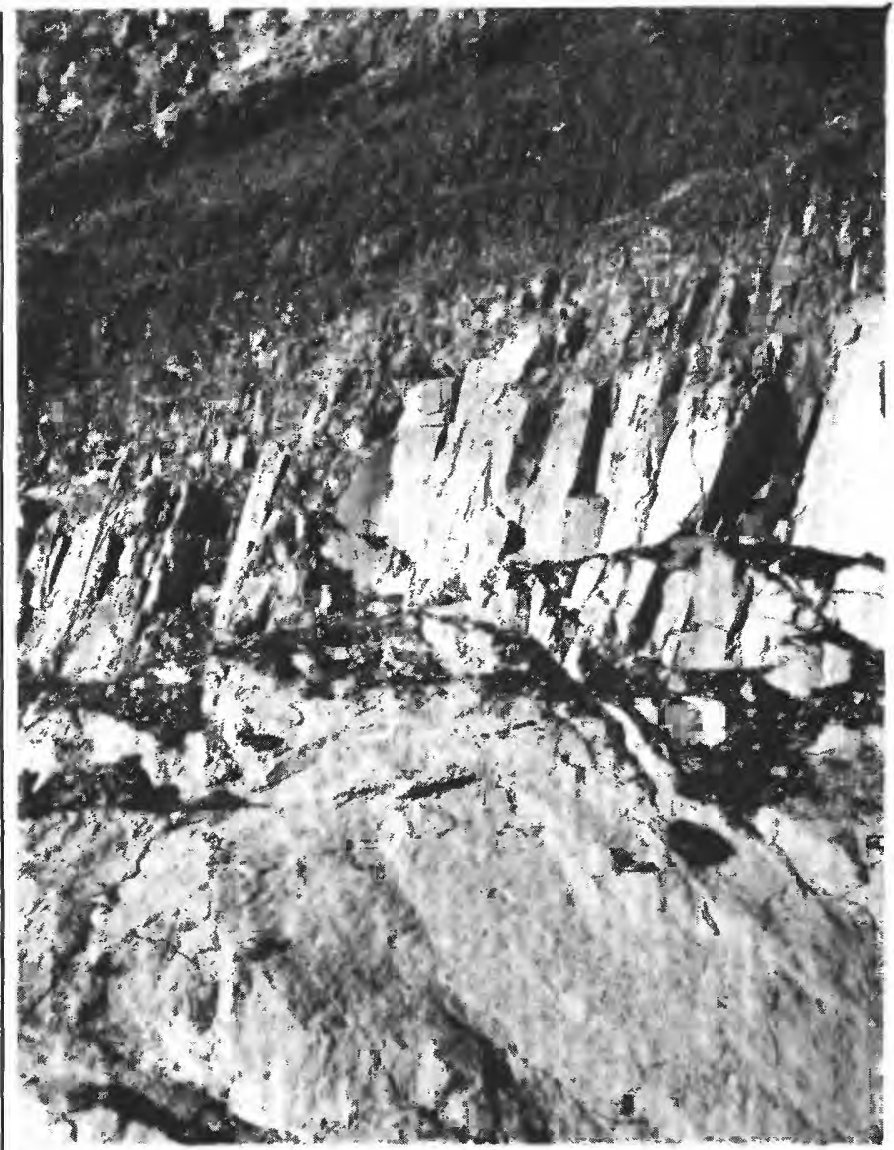

FIGURE 20. - Relation of joint density to degree of welding in ashflow tuff, 4 miles east of Shoshone, Calif. along Charles Brown Highway. Joints in black vitrophyre (upper one-third of photograph) are spaced $1 / 4$ to $1 / 2$ inch apart. Well-defined joints are absent in basal nonwelded part of ash flow (lower one-third of photograph). Light meter in foreground, 4 inches long.

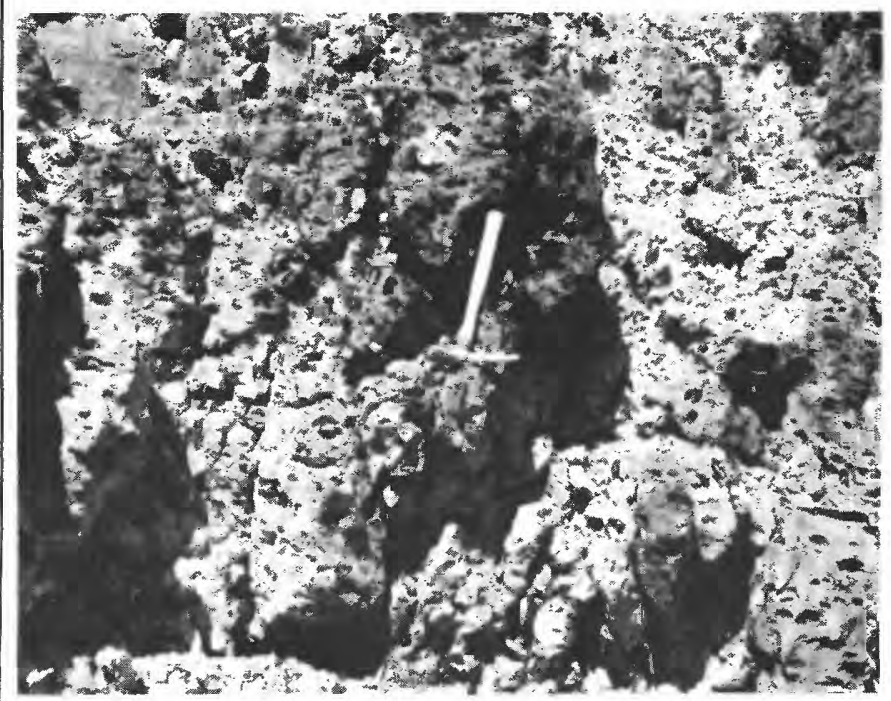

Figure 21. - Zone of lithophysal cavities in ash-flow tuff, Topopah Spring Member, western Jackass Flats. 
tact between flows, they may represent breakage along a plane of primary weakness after the removal of overburden from a prestressed rock; therefore, the partings are not likely to be open at depths of the regional water table (700 to $2,000 \mathrm{ft})$.

\section{CHARACTER BASED ON CORES AND DRILLING RECORDS}

Laboratory determinations of interstitial porosity and permeability of 20 core samples of the Topopah Spring, Tiva Canyon, and Rainier Mesa Members are summarized diagramatically in figure 18.

Interstitial porosity ranges from 3 to 48 percent. Interstitial permeability ranges from 0.000007 to $2.0 \mathrm{gpd}$ per sq $\mathrm{ft}$. These data indicate that the interstitial permeability of the densely welded zones is extremely low and probably prevents movement of ground water through these rocks. They also indicate that interstitial porosity and permeability of some nonwelded and partially welded tuff may be significant to ground-water movement. In general, both interstitial porosity and interstitial permeability vary inversely with degree of welding (fig. 18).

Secondary fractures in the cores are joints, thin brecciated zones, vuggy veinlets, and slickensides. The fractures are commonly sealed by gouge, clay, or mineral oxides. They dip at high angles, are less than 0.04 inch in width, and extend completely across the cores. The total number of fractures commonly averages 1 per foot and ranges from 0 to 20 per foot. The volume of fracture fillings is generally less than 2 percent of the core; only a fraction of this percentage contains vuggy or other porosity.

Fault planes and associated breccia zones might also be considered as potential zones of high transmissibility. However, the breccia zones in cores were usually tightly sealed.

Records of holes drilled on Rainier Mesa and in Yucca Flat suggest open and interconnected fractures in the welded-tuff aquifer. When mud was used as the circulating medium in rotary drilling, circulation losses occurred repeatedly during drilling of the Rainier Mesa Member.

The water-bearing fractures are probably restricted principally to the zone of partial to dense welding. Fractures are unlikely to remain open in the friable, nonwelded parts of ash-flow tuffs. For these reasons, the ashflow tuffs of the Paintbrush Tuff and the Timber Mountain Tuff are termed the "welded-tuff aquifer." The name emphasizes the location of the chief water-bearing zones within the welded part of an ash-flow tuff.

\section{PUMPING AND BAILING TESTS}

The hydraulic properties of the Topopah Spring Member were tested in three wells by pumping and in one well by bailing. Wells $73-58,74-57$, and 74-61 are in
Jackass Flats, and well 81-69 is in southern Yucca Flat. The methods of testing were the same as those used in tests of the lower carbonate aquifer. These four tests indicate a wide range in specific capacity and transmissibility (table 3 ). The specific capacity ranges from 0.1 to $56 \mathrm{gpm}$ per foot of drawdown, and the transmissibility ranges from 200 to 100,000 gpd per ft. The transmissibility of the three wells in Jackass Flats ranges from 28,000 to $100,000 \mathrm{gpd}$ per $\mathrm{ft}$. Semilog plots of two of these tests are given in figures 22 and 23.

The semilog plot of well 74-61 (fig. 22) is marked by an initial steep limb that gradually flattens into a gentle limb within the first 20 to 30 minutes of the pumping test; the gentle limb persists for about 70 minutes. The dual-limb configuration is probably due to the same factors causing such time-pressure behavior in the lower carbonate aquifer.

The time-drawdown curve of well 74-57(fig. 23) is unique among the curves for Nevada Test Site wells in that the semilog plot does not exhibit the initial steep limb on the time-pressure curve. Absence of the initial steep limb may be due to the full penetration of the aquifer; however, other interpretations are possible.

Negative hydraulic barriers are evident on the semilog curve for well 74-57 (fig. 23) and in expanded-scale plot for well 74-61, and one was reported by R. A. Young (oral commun., Sept. 1966) for well 73-58. This condition suggests that the welded-tuff aquifer, as well as the lower carbonate aquifer, is locally compartmentalized. Positive evidence of compartmentalization of the Topopah Spring Member is presented on geologic maps of Jackass Flats (McKay and Williams, 1964; and Lipman and McKay, 1965), which show that the Topopah Spring Member crops out and is entirely above the water table within 1 to $1 \frac{1}{2}$ miles of the three wells tapping this aquifer. The significance of these boundaries to the longterm use of the Topopah Spring Member as an aquifer in Jackass Flats is the subject of a report by R. A. Young (1972).

Hydraulic tests of welded tuffs older than the Topopah Spring Member (the Grouse Canyon and the Tub Spring Members of the Indian Trail Formation, and the Tuff of Crater Flat; table 1) suggest that these older tuffs are aquitards in Yucca, Frenchman, and Jackass Flats.

\section{BEDDED-TUFF AQUIFER}

The bedded-tuff aquifer comprises ash-fall tuff interbedded with Tiva Canyon and Topopah Spring Members of Paintbrush Tuff and the Grouse Canyon Member of Indian Trail Formation (table 1). Locally, as at Rainier Mesa, the ash-fall tuffs aggregate several hundred feet in thickness, although they are generally less than 100 feet thick. Because these ash-fall tuffs are highly variable in thickness and extent, they have not been assigned formal geologic names. 


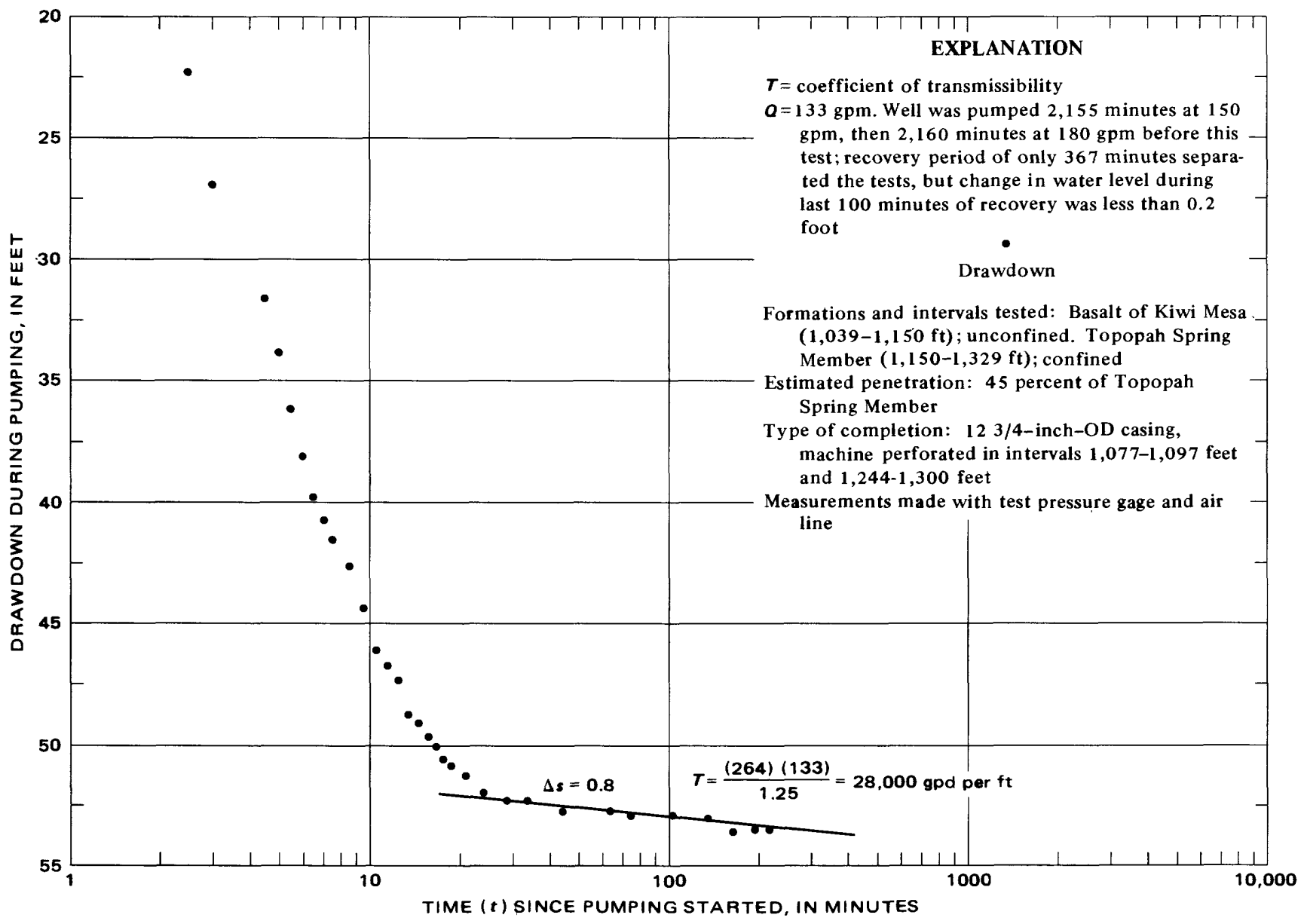

FigURE 22. - Semilog graph of drawdown of water level during pumping test in well 74-61, December 18, 1958.

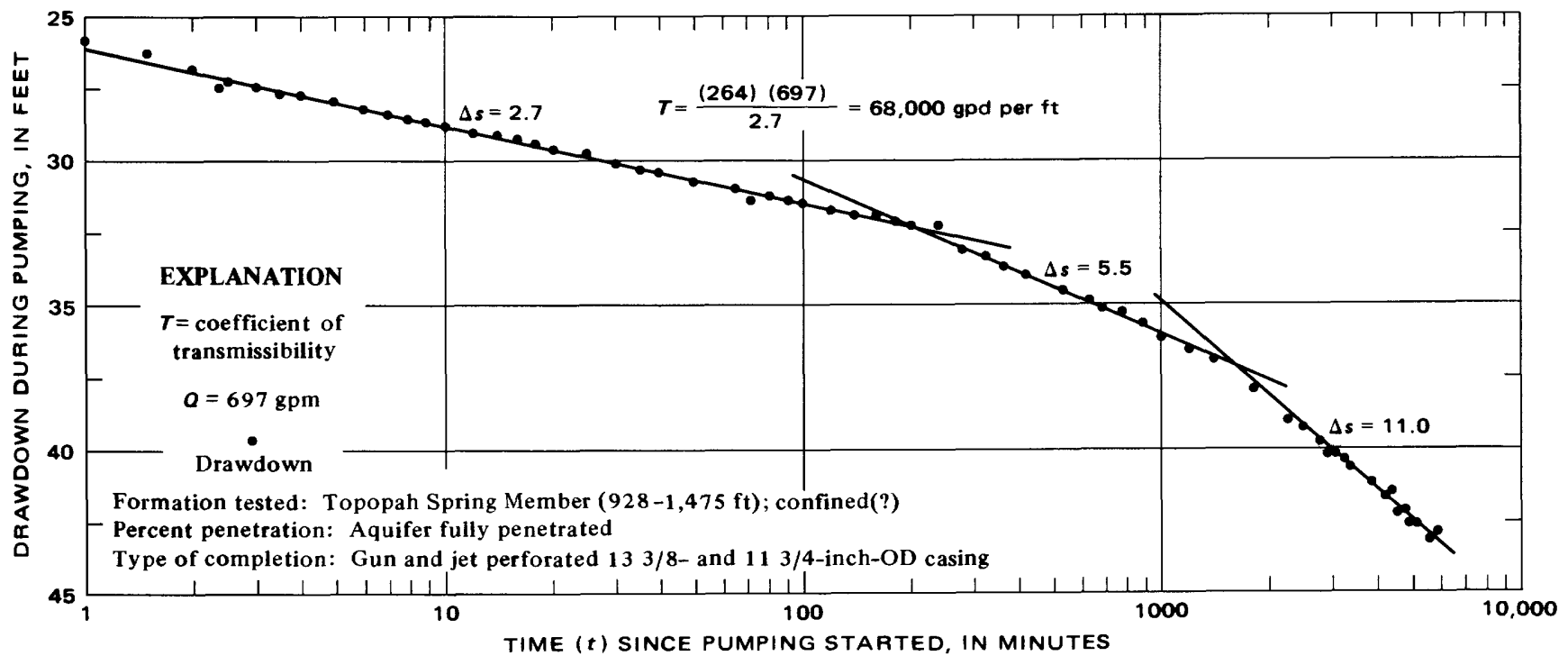

FIGURE 23. - Semilog graph of drawdown of water level during pumping test in well 74-57, February 18-22, 1964. 


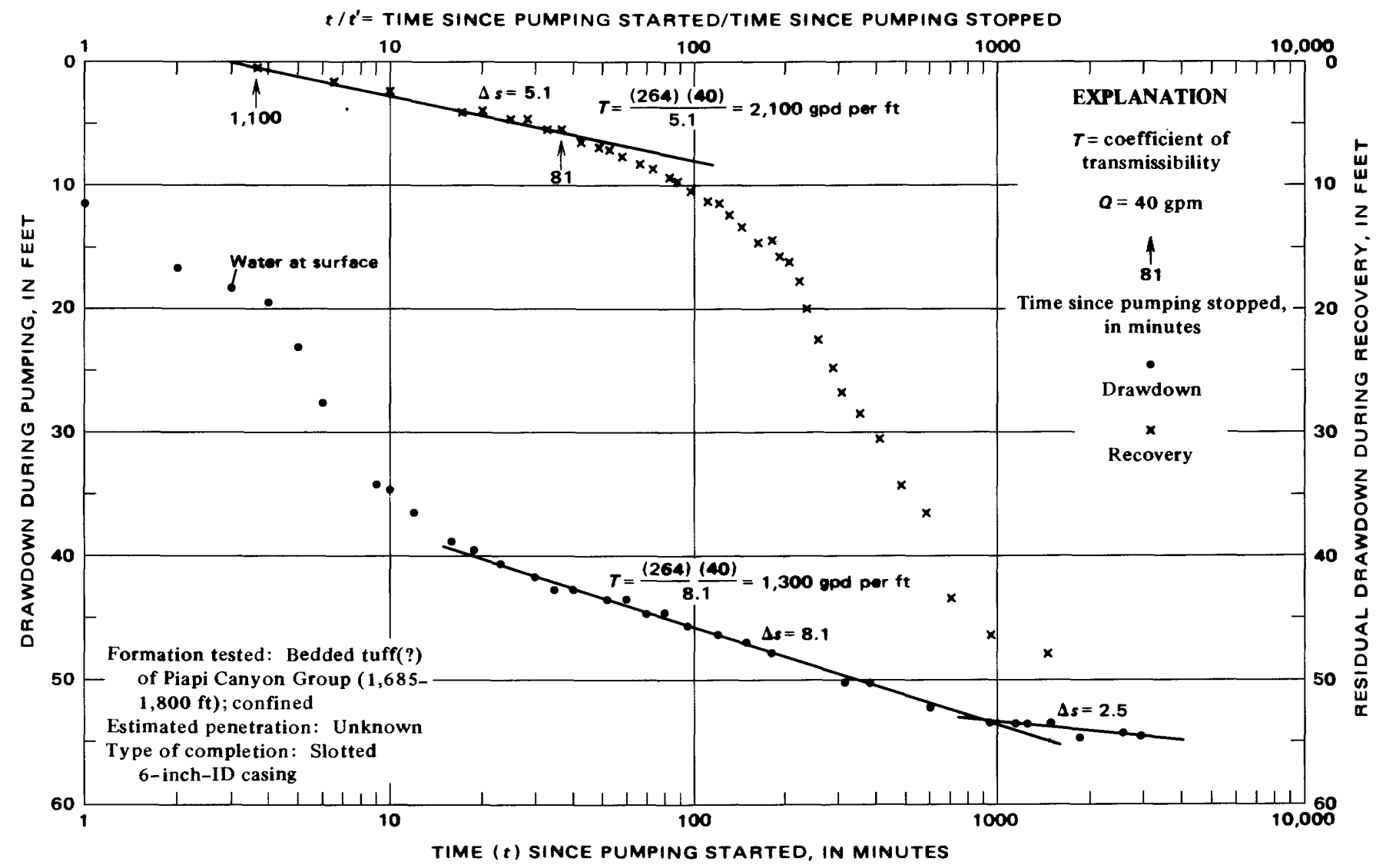

FIGURE 24. - Semilog graphs of drawdown and residual drawdown of water level during pumping test in well 81-67, October 2-4, 1959.

The ash-fall tuffs are fine grained to granule sized, poorly to well sorted, and highly friable. Locally, they have been either reworked by running water or deposited in standing water. They are distinctly stratified and possibly should be classified as tuffaceous sandstones, siltstones, and mudstones.

The highly friable nature of these rocks appears to preclude the existence of open joints or faults within them; open fractures were not seen in hundreds of feet of tunnels driven in these rocks beneath Rainier Mesa. Laboratory studies of cores and hand specimens by Thordarson (1965) indicated that interstitial porosity of 48 samples averaged 40 percent, and interstitial permeability of 11 samples ranged from 0.07 to $4.1 \mathrm{gpd}$ per sq $\mathrm{ft}$. The permeability of 3 samples not cited by Thordarson ranged from 0.7 to $18 \mathrm{gpd}$ per sq ft. The cited permeability values are representative of only vitric ashfall tuffs; that is, the glass shards composing the tuff are unaltered.

Where the glass shards are altered to zeolite or clay minerals, the permeability is reduced by several orders of magnitude. In general, the bedded tuffs of the Piapi Canyon Group are unaltered and locally constitute aquifers. The bedded tuffs in and below the Wahmonie Formation, except those associated with the Grouse Can- yon Member, are generally altered to zeolite or clay; these rocks compose part of the tuff aquitard described in this report.

The bedded-tuff aquifer was probably tapped by three wells at the Nevada Test Site (81-67, 90-74, and 90-75). Results of pumping tests of these wells are tabulated in table 3 , and the semilog plot of the test of well 81-67 is presented in figure 24. The pumping-test data indicate that the coefficients of transmissibility of the beddedtuff aquifer range from 200 to $1,000 \mathrm{gpd}$ per $\mathrm{ft}$ (table 3).

\section{LAVA-FLOW AQUIFER}

The Basalt of Skull Mountain, the Rhyolite of Shoshone Mountain, and the Basalt of Kiwi Mesa compose the lava-flow aquifer. The lava flows composing these three units, respectively, aggregate as much as 250 , 2,000 , and 250 feet in thickness (table 1 ). These strata are restricted to the Jackass Flats area. Their areal distribution is shown on the geologic maps by McKay and Williams (1964) and Lipman and McKay (1965). The rocks possibly lie within the zone of saturation beneath parts of east-central Jackass Flats. Well 74-61 penetrated 111 feet of the Basalt of Kiwi Mesa and 179 feet of the underlying Topopah Spring Member of Paint- 
brush Tuff (table 3 ). The transmissibility of the basalt is some fraction of that for the two aquifers, which is about 28,000 gpd per $\mathrm{ft}$.

Outcrop examinations of the Basalt of Kiwi Mesa and analogy with the water-bearing characteristics of basalts in other areas suggest that the movement of ground water through the basalt flows tapped by well 74-61 may be controlled by permeability and porosity developed along bedding planes and cooling joints. A transmissibility of several thousand gallons per day per foot would not be unlikely for wells tapping basalt flows composing either the Basalt of Kiwi Mesa or the Basalt of Skull Mountain.

Ground-water flow through the Rhyolite of Shoshone Mountain is probably controlled by secondary fractures; by analogy with the rhyolites beneath Pahute Mesa, the water-bearing fractures in rhyolites beneath Jackass Flats are probably sparse.

\section{VALLEY-FILL AQUIFER}

Alluvial-fan, fluvial, fanglomerate, lakebed, and mudflow deposits in depressions created by postPliocene block faulting are the valley fill. It constitutes the major aquifer used for water supply in Frenchman Flat, western Emigrant Valley, and Amargosa Desert. In Yucca Flat, western Jackass Flats, and Mercury Valley, the valley fill is either unsaturated or only locally saturated. The valley fill is at least 1,870 feet thick beneath central Yucca Flat (well 83-68) and at least 1,200 feet thick beneath central Frenchman Flat (well $74-70 \mathrm{~b}$ ); it is 1,040 feet thick at well $74-61$ in central Jackass Flats and is unsaturated. Because of the great depth to water in these valleys $(690$ to $1,915 \mathrm{ft})$, the saturated thickness of the valley fill is but a fraction of the thickness cited.

Faulting and erosion have exposed only the uppermost part of the valley-fill aquifer. Thus, outcrop examination of these strata as a means of studying their subsurface character was not useful. W. P. Williams, W. L. Emerick, R. E. Davis, and R. P. Snyder (written commun. June 1963) mapped and sampled the valley fill to a depth of 550 feet in a shaft (U2j) beneath the northwestern part of Yucca Flat. A few of their observations follow:

1. A marked and irregular variation exists in the percentage of detrital lithologies with depth.

2. The deposit contains large amounts of cobbles and boulders. At several intervals these materials constitute 65 to 75 percent of the deposit. At all depths in the shaft, except the 40- to 80-foot depth, they are the most abundant size-class material. Though minor, clay and silt are consistently present constituents.

3. The valley fill is generally poorly stratified to nonstratified and poorly sorted.
4. Strata are mostly horizontal and are commonly discontinuous from one wall of the shaft to the other.

5. Caliche is a common cementing material at all depths in the shaft. At no place is the valley fill so indurated or cemented that it cannot be dug easily with a miner's pick.

Price and Thordarson (1961) and Thordarson, Garber, and Walker (1962) presented data on valley fill penetrated by test wells $83-68$ and $84-67$ in central Yucca Flat; their descriptions agree with those of W. P. Williams, W. L. Emerick, R. E. Davis, and R. P. Snyder (written commun., June 1963), who also presented porosity data for the valley fill. They collected 42 samples from depths ranging from 500 to 1,500 feet in 20 drill holes and in the U2j shaft. The total interstitial porosity of the samples ranged from 16 to 42 percent and averaged 31 percent.

Lake beds, chiefly of illite, mixed-layer clay minerals, and montmorillonite, were penetrated in the depth interval 548 to 770 feet at the base of the valley fill in test well 81-69 in southern Yucca Flat (Moore and Garber, 1962). Data from other test holes in Yucca Flat do not indicate lake beds at the base of the valley fill elsewhere in the valley.

Six wells at the Nevada Test Site penetrate the valleyfill aquifer. Table 3 summarizes the results of pumping tests of those wells. The time-drawdown and the recovery plots of the tests of four of the wells are presented in figures 25-29. All the pumping tests were of the pumping well only.

Transmissibility of the valley-fill aquifer ranges from about 800 to 34,000 gpd per $\mathrm{ft}$ (table 3$)$. The transmissibility and the saturated-thickness data suggest average interstitial permeabilities of 5 to $70 \mathrm{gpd}$ per sq $\mathrm{ft}$.

A relatively short ( $48 \mathrm{hr}$ ) pumping test of the valleyfill aquifer gives reasonably correct coefficients of transmissibility. Figure 25 summarizes the results of a 48-hour pumping test of well 74-70b; coefficients of transmissibility of about 2,400 and 2,500 gpd per ft are indicated by drawdown and recovery data. Figure 26 summarizes the recovery of water level in this well during a subsequent shutdown period of 133 days. The 133day recovery curve indicates a coefficient of transmissibility of 1,700 gpd per $\mathrm{ft}$, or about 70 percent of that derived from the 48-hour test.

Pumping-test data for the valley-fill aquifer were not routinely corrected for dewatering. The dewatering in wells 91-74, 83-68, 74-70b, and 74-70a amounted respectively to about $5,10,20$, and 20 percent of the saturated thickness penetrated by each well. Using the procedure outlined by Jacob (1963), corrections of the drawdown in wells 83-68 and 74-70b for decrease in aquifer thickness due to dewatering were made and resulted in increases in transmissibility of only 10 to 15 percent; similar correc- 


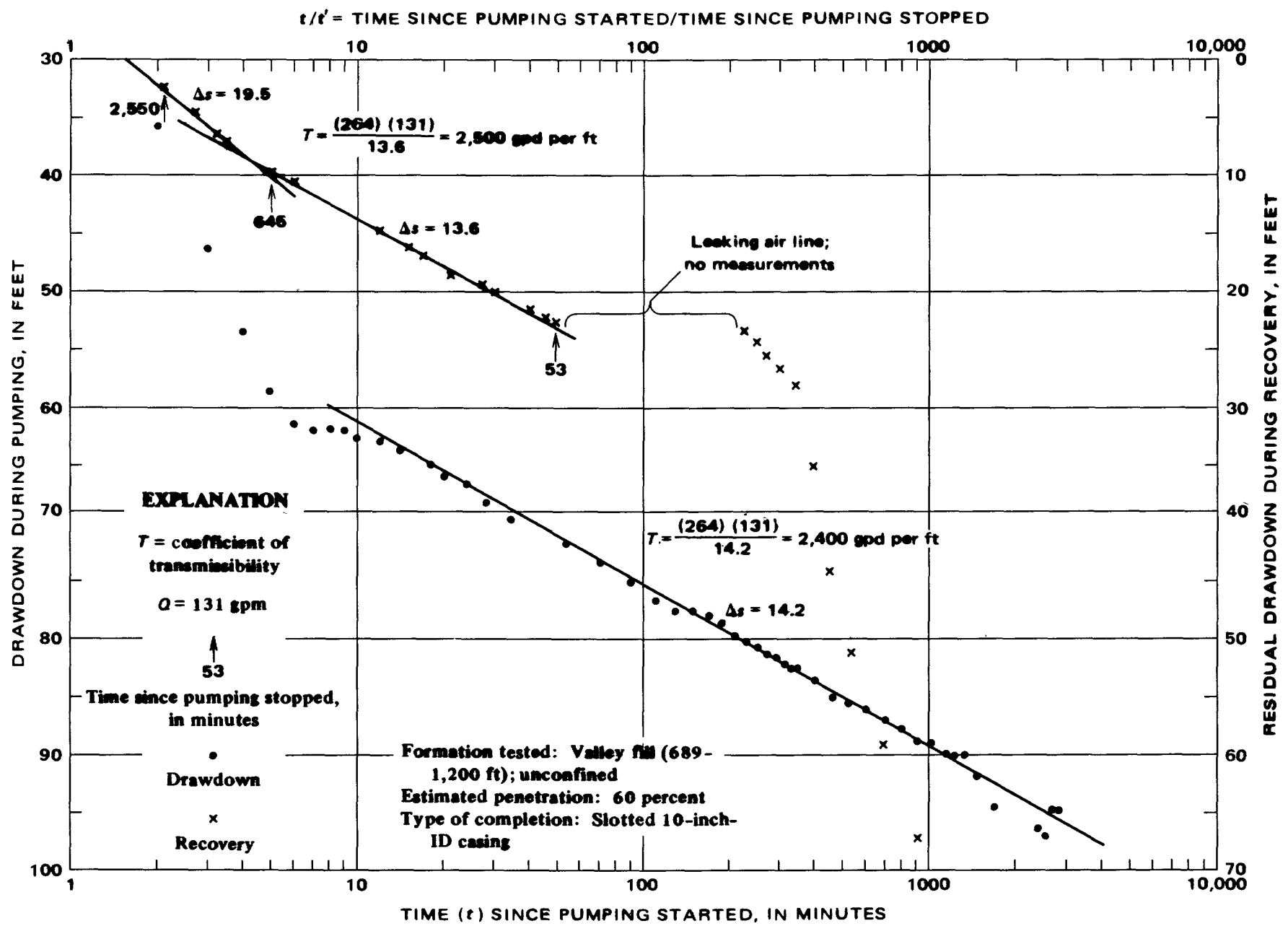

FIGURE 25. - Semilog graphs of drawdown and residual drawdown of water level during pumping test in well 74-70b, September 9-11, 1959.

tions for the other two wells in the valley fill did not appear essential.

Semilogarithmic plots of the drawdown and the recovery data obtained during pumping tests of the valley-fill aquifer superficially resemble those for carbonate-rock and welded-tuff aquifers. However, significant differences exist. In two of the three wells for which both recovery and drawdown data are available, 74-70b and 83-68, the coefficients of transmissibility from either type of data are nearly equal (table 3 and figs. 25 and 28); and recovery in these wells was not more rapid than the drawdown. In the third well, 74-70a, the coefficient of transmissibility derived from the recovery curve is only 50 percent greater than that indicated by the drawdown curve (fig. 27).

Wells tapping the valley-fill aquifer penetrate an estimated 15 to 100 percent of the aquifer. Incomplete penetration and the resulting crowding of flow lines near the bore may explain the initial steep limb of the timepressure curves. Leaky-aquifer conditions may also in- fluence the pressure response of the valley-fill aquifer to pumping.

\section{AQUITARDS}

Four of the 10 geohydrologic units of this report are aquitards (table 1). The lower clastic aquitard and the tuff aquitard have the widest areal distribution within the zone of saturation and play a key role in the regional movement of ground water. The lower clastic aquitard is the hydraulic basement for ground-water movement within the miogeosynclinal carbonate rocks throughout the study area, whereas the tuff aquitard effectively separates the Cenozoic from the Paleozoic aquifers in Yucca Flat, Frenchman Flat, Jackass Flats, and other valleys. The upper clastic aquitard occurs within the zone of saturation chiefly in western Yucca Flat and northern Jackass Flats, whereas the lava-flow aquitard is restricted to a small area in the central part of the Nevada Test Site.

Aquitards differ widely in their geologic origin and 


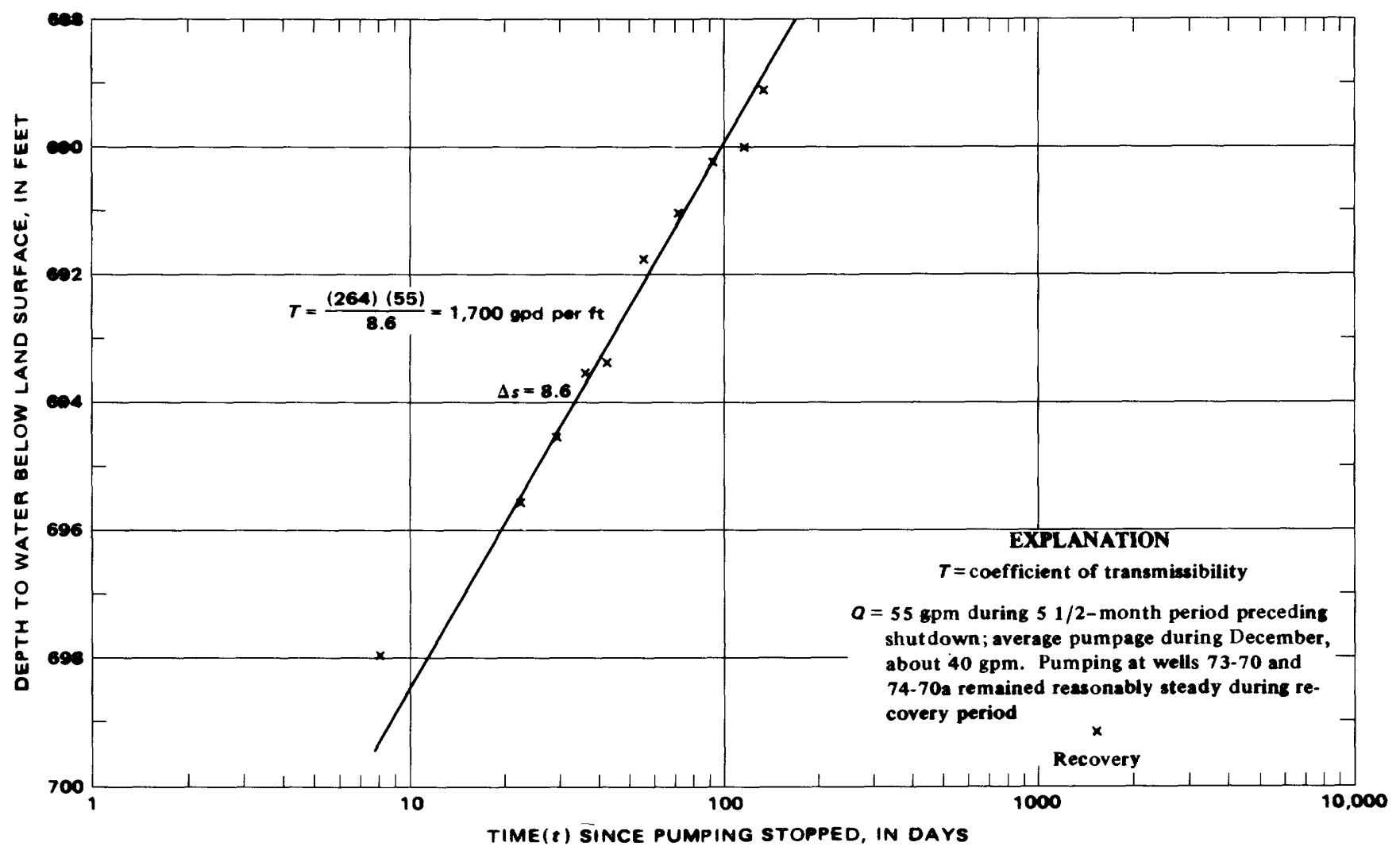

FiguRE 26. - Semilog graph of recovery of water level during 133-day shutdown in well 74-70b, December 23, 1960, to May 4, 1961.

their physical properties; all have low fracture transmissibility, usually less than $500 \mathrm{gpd}$ per $\mathrm{ft}$ for several thousand feet of saturated rock, and negligible interstitial permeability. The specific capacity of wells tapping these rocks is usually less than $0.1 \mathrm{gpm}$ per foot of drawdown per 1,000 feet of saturated rock.

In this report, the arbitrary dividing line between an aquifer and an aquitard is a specific capacity of about 0.1 gpm per foot of drawdown for 1,000 feet of saturated rock. Specific capacity of the aquitards rarely exceeds this value, and that of the carbonate and the welded-tuff aquifers may locally be as low as $0.2 \mathrm{gpm}$ per foot of drawdown for several hundred feet of saturated rock. Thus, the value chosen is an approximate dividing point between the most permeable aquitard and the least permeable fractured aquifer.

The very low transmissibility of the aquitards limits the type and the duration of hydraulic tests that can be run in wells tapping these units and prevents routine analysis of the hydraulic data. The specific-capacity values cited for the aquitards should be considered only as a crude measure of the transmissibility of waterbearing fractures in these units. Specific-capacity values given in the following pages are probably maximum values of this parameter.

\section{LOWER CLASTIC AQUITARD}

The lower clastic aquitard comprises all siltstone, quartzite, shale, and sandstone of Precambrian through Early Cambrian age - that is, the clastic rocks of Johnnie Formation, Stirling Quartzite, Wood Canyon Formation, Zabriskie Quartzite, and the lower half of the Carrara Formation (table 1). These clastic rocks aggregate about 10,000 feet in thickness, although such a thickness is not present everywhere owing to the effects of faulting, folding, and erosion. The outcrop pattern of the lower clastic aquitard and its inferred distribution within the uppermost part of the zone of saturation are shown on plate 1 .

CHARACTER BASED ON OUTCROP, CORES AND DRILLING RECORDS

In outcrop, the clastic rocks of the lower clastic aquitard resemble rocks of the lower carbonate aquifer in several ways. First, when viewed through a hand lens, the rocks seem to have negligible interstitial, or matrix permeability. Second, the clastic strata are highly fractured and are locally brecciated; locally, quartzite seems noticeably more fractured than the more porous siltstone, shale, and sandstone. Third, secondary 


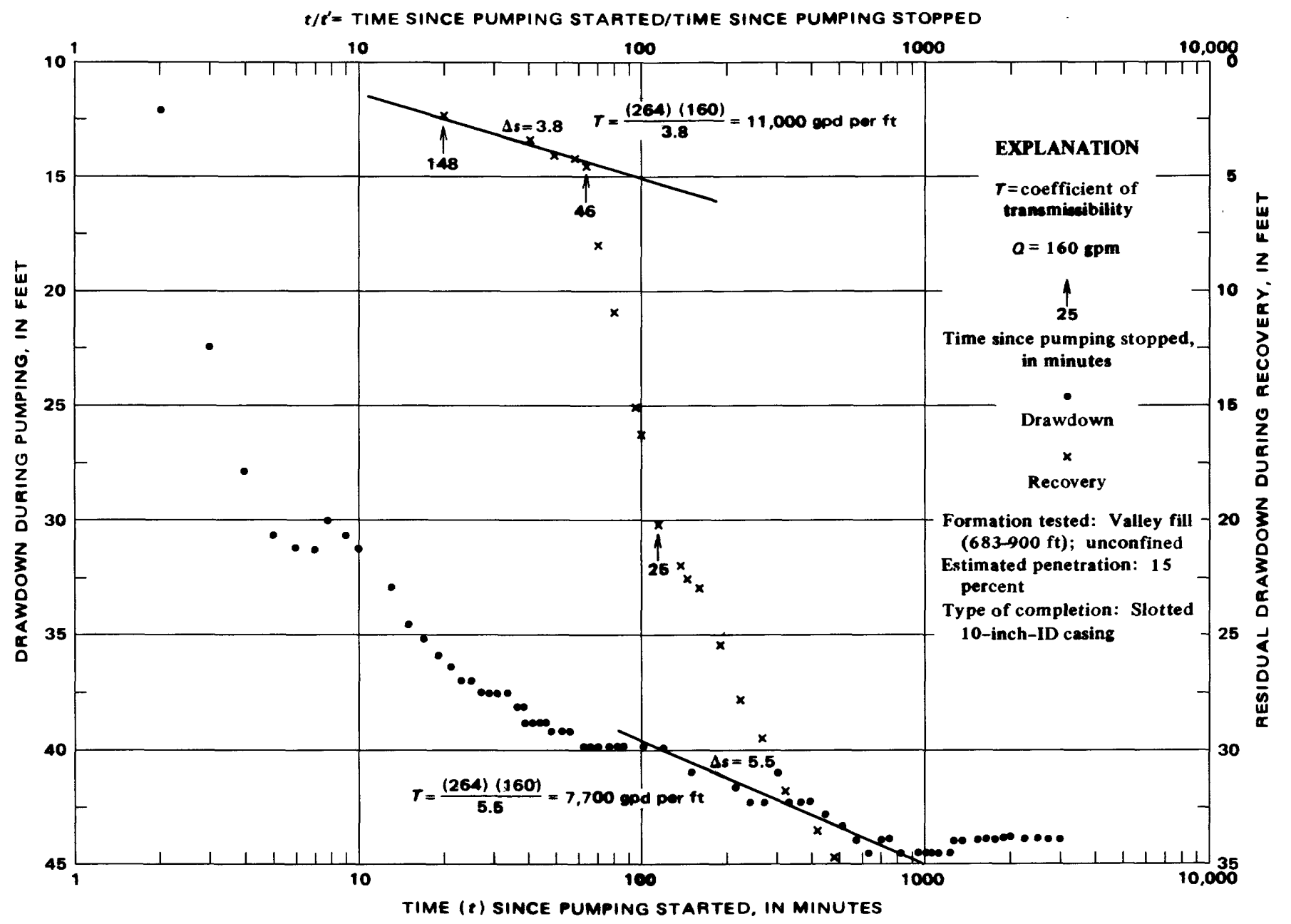

FIGURE 27. - Semilog graphs of drawdown and residual drawdown of water level during pumping test in well 74-70a, August 27-29, 1959.

porosity occurs along joints in the quartzitic rocks and more rarely in sandstone, shale, and siltstone. All this secondary porosity is probably due to subaerial weathering.

Clastic rocks differ from carbonate rocks in two important ways. First, secondary porosity rarely develops along bedding planes in any of the clastic rocks. The absence of such secondary porosity is probably due to the low solubility of the clastic strata, whose major constituents are quartz, mica, and clay minerals. Second, the mode of deformation of some of the clastic rocks differs significantly from that of the carbonate strata. Siltstone, shale, and sandstone commonly exhibit tight folding, slaty cleavage, and shearing in outcrop, whereas carbonate rocks and quartzite, though highly fractured, tend to form relatively broad folds. The difference in mode of deformation is probably due to differences in the strength of the rocks. The dense carbonate and quartzitic rocks respond to stresses as a brittle solid, at least under relatively shallow overburden; the more porous finer grained rocks tend to deform plastically. The com- mon absence, in outcrop, of the Dunderberg Shale Member of the Nopah Formation is a good example of the squeezing out or marked thinning of an argillaceous rock in response to deformation. This difference in response to deformational forces has been specifically cited by Vincelette (1964) in his discussion of the geology of the northwestern Spring Mountains.

The potential hydrologic significance of plastic deformation of siltstone and shale is twofold. First, in these rocks the fractures formed during folding or faulting tend to be sealed by the same process that formed them. Second, wherever quartzites are interbedded with argillaceous strata, as is common in parts of the Stirling Quartzite and the Wood Canyon Formation, open fractures in the quartzites tend to be isolated or even sealed by the plastic deformation of the weaker strata. Figure 6 is a photograph of the flowage of shale into fractures in more competent rock.

Micaceous partings and laminae are abundant within the quartzitic parts of the Johnnie and the Wood Canyon Formations. These partings are also likely to deform 


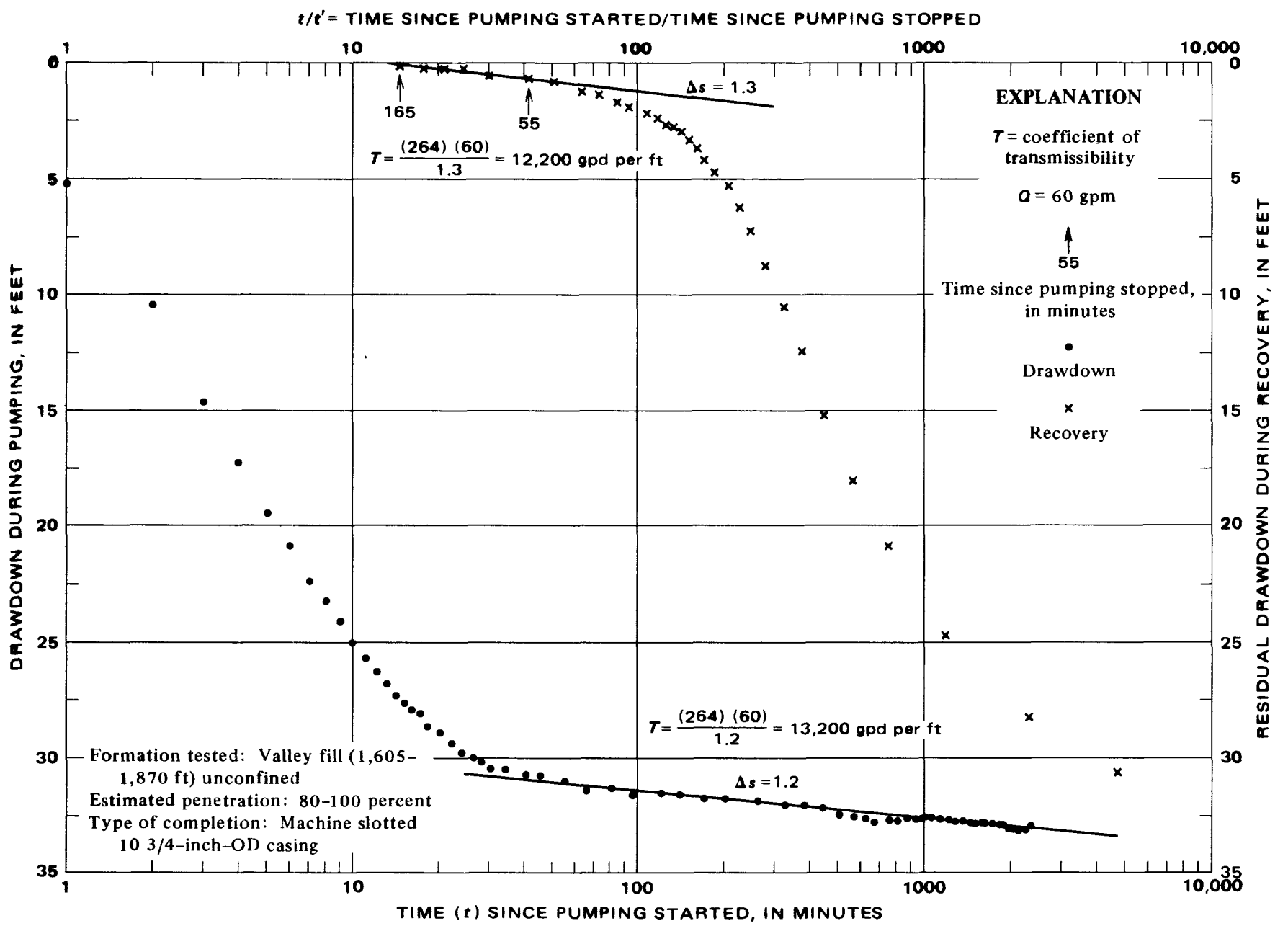

FIGURE 28. - Semilog graphs of drawdown and residual drawdown of water level during pumping test in well 83-68, September 20-21, 1960.

plastically and, thereby, seal or isolate the fractures in brittle quartzite. However, in those parts of the Stirling Quartzite and the Zabriskie Quartzite that contain few or no micaceous partings or argillaceous interbeds, interconnected secondary fracture porosity is possible; and locally these rocks may be aquifers.

Secondary porosity is generally absent in the subsurface. About 3,500 feet of quartzite, siltstone, and argillite of the Stirling Quartzite and the Johnnie Formation were penetrated in well 89-68. About 10 percent of this footage was cored. All the cores were highly fractured and locally brecciated. The fractures were commonly lined with micaceous and chloritic selvage or were marked by slickensides. The brecciated zones were sealed with quartz or calcite veinlets. For each of 35 core runs the average number of major fractures per foot of core ranged from two to five; locally, the microfracturing was intense. In some quartzite, the shattering was so intense that almost every sand grain was bounded by a microfracture. Most of the fractures were tightly sealed either by selvage minerals or by quartz or calcite veinlets, or by virtue of their never having been opened. Only two cored intervals in the aquitard in well 89-68 contained joints that appeared to have significant secondary porosity.

The interstitial porosity and the interstitial permeability of 43 cores from the lower clastic aquitard in test well 89-68 are given in table 4 . Although restricted to cores from a single test hole, the data are considered

TABLE 4. - Interstitial porosity and permeability of cores from the lower clastic aquitard, well 89-68, Yucca Flat

['Total porosity, in percent, determined from grain and bulk densities; effective porosity, in percent, determined by mercury-injection or water-saturation methods; permeability, in Geol. Survey, Denver, Colol

\begin{tabular}{|c|c|c|c|c|}
\hline $\begin{array}{l}\text { Porosity or } \\
\text { permeability }\end{array}$ & $\begin{array}{l}\text { Number of } \\
\text { samples }\end{array}$ & Range & Median & Mean \\
\hline Total porosity & 23 & $0.2-10.0$ & 3.9 & 3.8 \\
\hline Effective porosity & 20 & $0.6-5.0$ & & \\
\hline Permeability & 18 & $0.0000007-0.0001$ & .000002 & .00001 \\
\hline Effective porosity of & & & & \\
\hline $\begin{array}{l}\text { argillite and silitstone } \\
\text { Effective porosity of -- }\end{array}$ & 10 & $0.7-3.6$ & 2.0 & 2.0 \\
\hline 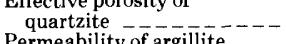 & 10 & $0.6-5.0$ & 1.4 & 1.9 \\
\hline $\begin{array}{l}\text { Permeability of argillite } \\
\text { and siltstone }\end{array}$ & 9 & $0.0000007-0.000007$ & .000002 & .000002 \\
\hline Permeability of quartzite & 9 & $0.000002-0.0001$ & .00001 & .00002 \\
\hline
\end{tabular}




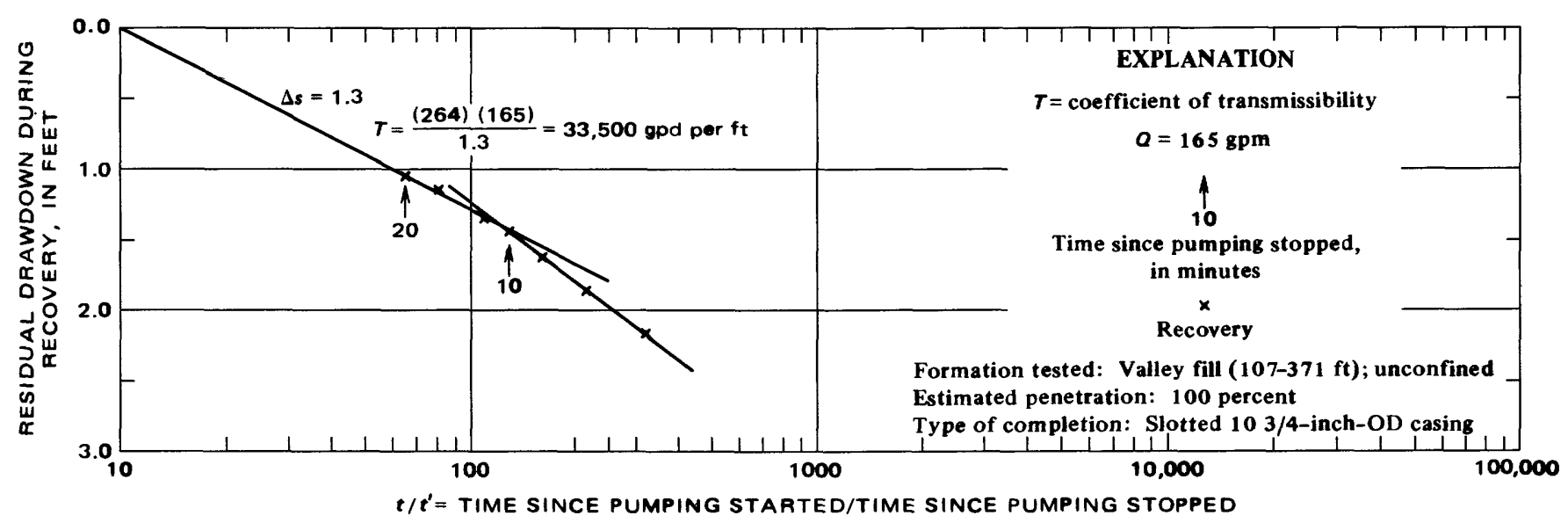

FIGURE 29. - Semilog graph of residual drawdown of water level during pumping test in well 91-74, November 23-25, 1959.

representative of the lower clastic aquitard throughout the study area because the hole tapped 3,517 feet of aquitard (see below) and the cores resemble examined outcrop specimens.

\section{HYDRAULIC TESTS}

Pumping or bailing three test wells (well 66-69 in Mercury Valley, well 68-60 in southwestern Rock Valley, and well 89-68 in northern Yucca Flat) gave some measure of the fracture transmissibility of the lower clastic aquitard. The results indicate specific capacity ranging from 0.01 to $0.27 \mathrm{gpm}$ per foot of drawdown for wells penetrating differing thicknesses of saturated rock. After normalizing to 1,000 feet of saturated rock, the specific capacities range from $0.04 \mathrm{gpm}$ per foot of drawdown in well 68-60 to about $0.1 \mathrm{gpm}$ per foot of drawdown in well 66-69.

The pumping test of well 89-68 was most instructive because of the great thickness of clastic rocks penetrated. This well penetrated large thicknesses of Stirling Quartzite (587 ft), Johnnie Formation $(2,930 \mathrm{ft})$, and Noonday(?) Dolomite $(710 \mathrm{ft}) .^{2}$ The specific capacity of the well was $0.27 \mathrm{gpm}$ per foot of drawdown at the end of a 36-hour pump test; the apparent fracture transmissibility derived from the second limb of the drawdown curve is 600 gpd per ft. Lost-circulation records and geophysical logs indicate that a fault zone (depth 5,290 ft) separating the Johnnie Formation from the Noonday(?) Dolomite is one of the major zones of transmissibility penetrated by the bore. Thus the specific capacity of the 3,517 feet of the Stirling Quartzite and the Johnnie Formation penetrated is less than $0.27 \mathrm{gpm}$ per foot of drawdown, and the transmissibility is less than $600 \mathrm{gpd}$ per $\mathrm{ft}$, because of the yield of the fault zone. Ignoring the yield of the fault zone and the

\footnotetext{
-The Noonday(?) Dolomite, which underlies the Johnnie Formation (table 1), is considered part of the lower clastic aquitard; it is stratigraphically separated from the lower carbonate aquifer by as much as 10,000 feet of the lower clastic aquitard.
}

possible yield of Noonday(?) Dolomite, the average specific capacity of the Stirling Quartzite and Johnnie Formation on a 1,000 -foot basis can be no greater than $0.08 \mathrm{gpm}$ per foot of drawdown; this suggests a coefficient of transmissibility on the order of $150 \mathrm{gpd}$ per $\mathrm{ft}$ per 1,000 feet of aquitard.

Hydraulic tests of two wells (67-68 in Mercury Valley and 67-73 in western Indian Springs Valley) which tap the Dunderberg Shale Member of the Nopah Formation (table 1) confirmed the results obtained for the lower clastic aquitard. The specific capacity of the Dunderberg Shale Member, on a 1,000-foot basis, is less than $0.3 \mathrm{gpm}$ per foot of drawdown in each well.

Several thin strata within the Stirling Quartzite and the Zabriskie Quartzite of the lower clastic aquitard (table 1) are free of argillaceous laminae. The fracture transmissibility of these strata, not yet tested by drilling, might locally be as high as 10,000 gpd per $\mathrm{ft}$. However, for the bulk of the aquitard, available data suggest that the coefficient of transmissibility probably does not exceed 1,000 gpd per ft locally. Regional flow through the aquitard may be governed principally by interstitial permeability for reasons suggested in the following section of the report.

\section{REGIONAL EVIDENCE OF LOW TRANSMISSIBILITY}

The best comparative qualitative evidence on the gross fracture transmissibility of the lower clastic aquitard and the carbonate aquifers is derived from tabulations of spring discharge in that part of eastern Nevada underlain by miogeosynclinal rocks. Such a discharge tabulation was prepared by Maxey and Mifflin (1966) for springs discharging more than $450 \mathrm{gpm}$. These springs, yielding as much as $8,000 \mathrm{gpm}$ per spring, discharge from carbonate rocks at valley level or from valley fill immediately adjacent to carbonate-rock outcrops; none of the major springs reportedly discharges from clastic rocks or valley fill adjacent to clastic rocks. 
Individual springs associated with valley-level carbonate rocks in the study area yield as much as 2,800 gpm, whereas those springs associated with clastic strata yield less than $25 \mathrm{gpm}$ and are restricted to the northwestern Spring Mountains. The highest reported yield of a spring associated with clastic strata in the vicinity of the study area is $150 \mathrm{gpm}$ at Resting Spring, Inyo County, Calif. (sec. 31, T. 21 N., R. 8 E.), about 10 miles south of the area of figure 1 . This spring emerges from valley fill immediately east and topographically upgradient from a quartzite ridge. Hughes (1966) interpreted the quartzite ridge as a barrier forcing water out of the valley fill, rather than as the source of the water.

The apparent absence of high- or even moderate-yield springs in the clastic miogeosynclinal strata in Nevada probably reflects the absence of regionally integrated fracture transmissibility. Although the clastic strata were subjected to the same deformation as the carbonate rocks and consequently are as highly fractured, their apparent lack of integrated fracture porosity is probably due to (1) their low susceptibility to solution, (2) the tendency of the clastic argillaceous rocks to deform plastically, and (3) the tendency of micaceous partings and laminae to seal fractures in the brittle quartzite rocks. Thus, the regional movement of water through these rocks is probably governed by their very low interstitial permeability (table 4) rather than by fracture transmissibility (as measured locally by well tests).

\section{UPPER CLASTIC AQUITARD}

In this report, the upper clastic aquitard is synonymous with the Eleana Formation of Late Devonian to Late Mississippian age (table 1). The Eleana Formation consists predominantly of argillite, quartzite, and conglomerate and is as much as 8,000 feet thick in western Yucca Flat; the argillite composes about two-thirds of the formation. The upper clastic aquitard (table 1) is of hydrologic importance only beneath western Yucca Flat and northern Jackass Flats. Beneath these areas, the Eleana Formation is thousands of feet thick and stratigraphically and hydraulically separates the upper and the lower carbonate aquifers (table 1); its outcrop pattern and probable subsurface distribution in the upper part of the zone of saturation is shown on plate 1 . Elsewhere at Nevada Test Site the Eleana Formation has been removed by erosion, occurs hundreds of feet above the regional water table, or is represented by equivalent rocks of carbonate lithology.

Visual examination of selected outcrops and binocular-microscopic examination of hand specimens indicate that certain features of the Eleana Formation resemble those of the lower clastic aquitard. Although the argillites probably have moderate interstitial porosity, the interstitial permeability of those rocks and of the quartzites and conglomerates appears negligible. Secondary porosity is poorly developed along fractures and, where present, appears entirely due to subaerial weathering. This formation as well as the lower clastic aquitard probably respond to deformation by shearing and tight folding; open fractures are unlikely to occur in the rock at depth. The tendency of the formation to deform plastically is evidenced by its behavior as the principal glide plane (or lower plate) for several major thrust faults at the Nevada Test Site.

Laboratory analyses of 22 outcrop samples of the Eleana Formation indicate a moderate total porosity but a small effective porosity. The total porosity, ranging from 2.0 to 18.3 percent, has a median value of 6.1 and a mean value of 7.6 percent. The effective porosity, ranging from 0.6 to 15.1 percent, has a median value of 3.4 and a mean value of 4.2 percent (F. G. Poole, written commun., Sept. 1966). The samples consisted of 14 specimens of sandstone, 6 of conglomerate, and 2 of shale or argillite. No analyses of interstitial permeability of outcrop samples or cores were made; the interstitial permeability probably does not exceed the upper value ( $0.0001 \mathrm{gpd}$ per sq ft) for the lower clastic aquitard (table 4).

The Eleana Formation was hydraulically tested only in well 84-67, in central Yucca Flat. This well penetrated 84 feet of saturated dolomite and 133 feet of underlying argillite and minor dolomite. The results of this test by bailing indicate a specific capacity of about $0.18 \mathrm{gpd}$ per foot of drawdown for 217 feet of saturated rock, or 0.83 gpd per foot of drawdown per 1,000 feet of saturated aquitard. The relatively high yield of the aquitard (in comparison with that of the lower clastic aquitard and the Dunderberg Shale Member) in this well is attributed to 84 feet of saturated dolomite in the upper part of the unit.

By analogy with the lower clastic aquitard, the gross fracture transmissibility of the upper clastic aquitard is probably less than 500 gpd per ft; similarly, regional ground-water movement through the aquitard is probably controlled by interstitial permeability rather than fracture transmissibility.

\section{TUFF AQUITARD}

The tuff aquitard comprises all the tuffs and associated sedimentary rocks older than the Paintbrush Tuff (table 1). By definition, it includes the strata of the Wahmonie Formation, Salyer Formation, Tuff of Crater Flat, Rocks of Pavits Spring, Horse Spring Formation, Indian Trail Formation, and the rhyolite flows and tuffaceous beds of Calico Hills. These formations consist of nonwelded to incipiently welded ash-flow tuff, ash-fall (or bedded) tuff, tuff breccia, breccia flow, tuffaceous sandstone, siltstone, mudstone, freshwater limestone, 
and minor densely welded tuff. Despite their widely differing origins, these strata usually have one feature in common: matrices consisting of zeolite or clay minerals. The zeolitic or clayey matrices of these rocks are probably responsible for their very low interstitial permeability. The lenses of densely welded tuff in the Indian Trail Formation and the freshwater limestone in the Horse Spring Formation and in the Rocks of Pavits Spring may not have zeolitic or clayey matrices, but they are believed to have negligible interstitial and fracture permeability and are therefore included as part of the tuff aquitard. The bedded tuff associated with the densely welded tuff of the Grouse Canyon Member of the Indian Trail Formation is usually vitric and permeable; this bedded tuff is assigned to the bedded-tuff aquifer. The tuff aquitard, by virtue of its stratigraphic position (table 1), generally separates the Tertiary welded and bedded-tuff aquifers from the underlying Paleozoic aquifers and aquitards.

The tuff aquitard is as much as 2,000 feet thick in central Yucca Flat, where it consists of the Indian Trail Formation. The aquitard is more than 2,000 feet thick in western Jackass Flats, where it consists of the informally designated rhyolite flows and tuffaceous beds of Calico Hills. In Frenchman Flat the aquitard may aggregate more than 4,500 feet in thickness and consists primarily of the Wahmonie Formation, the Salyer Formation, and the Rocks of Pavits Spring. In Rock and Mercury Valleys the aquitard consists of the Rocks of Pavits Spring and the Horse Spring Formation.

\section{CHARACTER BASED ON OBSERVATIONS IN UNDERGROUND WORKINGS}

Geologic, geophysical, and hydrologic characteristics of zeolitized bedded tuff of the Indian Trail Formation were studied in more than 5 miles of tunnels, shafts, and drifts driven into these rocks beneath Rainier Mesa. These studies have been recorded in dozens of reports (Diment and others, 1958, 1959; McKeown and Dickey, 1961; Byers, 1961; Clebsch and Barker, 1960; Clebsch, 1960; and Thordarson, 1965). Thordarson (1965) observed that:

1. The average interstitial porosity of five beds of zeolitized (ash-fall) tuff ranged from 25 to 38 percent. The average interstitial permeability ranged from 0.0004 to 0.03 gpd per sq $\mathrm{ft}$.

2. Except near the portals of the tunnels, the interstices of the tuff are 100 percent saturated. Interstitial saturation occurs as much as 400 feet above the top of the zone of saturation within open fractures. High bulk capillarity and very low interstitial permeability are probably responsible for the saturation.

3. The only free ground water observed in the un- derground workings occurred in open fractures, mostly fault zones; however, not all open fractures were saturated.

4. The initial discharge of water from most of the fractures was less than $20 \mathrm{gpm}$, but the discharge from one fault zone was about $200 \mathrm{gpm}$. The discharge from all the fractures decreased rapidly, and within a few days it was a small fraction of the initial flow.

5. The water-bearing fractures were poorly connected or unconnected. The chief evidence for the poor connection was unsaturated fractures interspersed with saturated fractures at the same tunnel level; tunneling commonly intersected saturated fractures several hundred feet from other fractures which had been virtually dewatered several days earlier. The few static water levels available in wells or shafts indicated that the zone of fracture saturation had an irregular upper surface.

6. The nature of fractures was as follows:

(a) Faults and joints have steep to nearly vertical dips.

(b) Faults are scarce in comparison with joints.

(c) Most of the faults have stratigraphic displacements measured in inches, and many extend less than 300 feet.

(d) The widths of openings in faults and joints differ considerably. Some faults are open as much as 6 inches, whereas others are nearly sealed with fault gouge. The joints are generally closed but in places are open as much as several inches. Some fractures open several inches at one point are tightly closed within just a few feet along their strike.

7. Of the 110 faults and estimated 5,000 joints mapped in the U12e tunnel complex, 50 to 60 percent of the faults yielded most of the fracture water; a small percentage of the joints yielded a fraction of total water discharged.

8. Water in the fractures is perched above a buried ridge of unsaturated lower carbonate aquifer. The water is perched by the poor hydraulic connection of the fractures themselves. The poor hydraulic connection may reflect the slight extent of the fractures. Several thin clayey strata within the otherwise zeolitized and relatively competent tuff sequence may also be partly responsible for the perching, if the water-bearing fractures close within these thin strata.

9. The specific capacity of test hole $88-63 \mathrm{~b}$, drilled into the aquitard from the floor of the U12e.03 drift, was less than $0.01 \mathrm{gpm}$ per foot of drawdown. The hole had penetrated 614 feet of saturated aquitard at the time of the test. 
Maps of the U12e tunnel complex by McKeown and Dickey (1961) indicate joint densities as great as four per 10 feet of tunnel, although many segments of tunnel 20 to 40 feet in length are unjointed.

Thordarson's observations were of water perched in the tuff aquitard hundreds of feet above the regional zone of saturation in the underlying lower carbonate aquifer. J. E. Weir, Jr. (written commun., Mar. 1967), on the other hand, documented water in two chambers mined in the aquitard beneath Pahute Mesa at depths of as much as 2,000 feet below the regional water table. In one chamber $(1,000 \mathrm{ft}$ below water table), according to Weir, "Most of the water seemed to be entering through that part of the chamber containing the most fractures. However, all the chamber walls were damp to wet, which suggests that some water was also moving through the rock, rather than entirely through the joint or fracture system." The rate of water entry into this chamber, excavated in zeolitized bedded tuff and tuffaceous sediments, was less than $4 \mathrm{gpm}$. In a deeper chamber $(2,000 \mathrm{ft}$ below water table), ground water flowed only from microfractures in one side of the room at a rate of about $1 \mathrm{gpm}$, and the walls of the remainder of the chamber were dry. Interstitial seepage, if any, must have been evaporated at the chamber face by the forced air ventilation. Weir also noted that the initial yield from microfractures decreased with time.

Thordarson's (1965) observations and Weir (written commun., Mar. 1967) indicate that the zeolitized ashfall tuff and zeolitized tuffaceous sandstone should be classified as a fractured aquitard with high interstitial porosity but very low interstitial permeability. The fracture transmissibility of fault zones apparently ranges from nearly zero to a modest amount along some fault zones, but both the rapid drainage of these fractures and their interspersal with unsaturated fractures attests to their poor hydraulic connections. Accordingly, on a regional scale, ground-water movement through the tuff aquitard is probably controlled by the interstitial permeability of the rock rather than by fracture transmissibility.

The strata composing the tuff aquitard in the underground workings are predominantly zeolitized ashfall, or bedded, tuff and zeolitized tuffaceous sediments with minor clayey tuff. However, beneath Yucca Flat, Frenchman Flat, and Jackass Flats, nonwelded to partially welded ash-flow tuff, tuff breccia, siltstone, claystone, and freshwater limestone compose varying parts of the aquitard; these strata commonly have zeolitic or clayey matrices. Knowledge of their hydraulic characteristics was derived from several test holes in Yucca Flat, one hole (73-66) in northeastern Rock Valley, and one hole (74-57) in western Jackass Flats; these findings are described in the following two sections.

\section{CHARACTER BASED ON CORE AND ELECTRIC-LOG ANALYSES}

Interstitial porosity and permeability of the tuff aquitard beneath Yucca Flat and Rock Valley and the gross mineralogic character of the basal strata composing the aquitard in Yucca Flat were determined from core and electric-log analyses. Interstitial porosity and permeability of 72 cores of the tuff aquitard in Yucca Flat and Rock Valley are given in table 5. These cores were obtained from holes which completely penetrate the aquitard in Yucca Flat and in Rock Valley.

TABLE 5 - Interstitial porosity and permeability of cores from the tuff aquitard, Nevada Test Site

[Total porosity, in percent, determined from grain and bulk densities; effective porosity, in percent, determined by mercury-injection or water-saturation methods; permeability, in gallons per day per square foot, determined using Denver, Colo., tap water. Analyses by U.S.
Geol. Survey, Denver. Colo]

\begin{tabular}{|c|c|c|c|c|}
\hline $\begin{array}{c}\text { Porosity or } \\
\text { permeability }\end{array}$ & $\begin{array}{l}\text { Number of } \\
\text { samples }\end{array}$ & Range & Median & Mean \\
\hline \multicolumn{5}{|c|}{$\begin{array}{l}\text { Zeolitized tuff } \\
\text { [Chiefly ash-flow and ash-fall tuff with zeolitic matrices] }\end{array}$} \\
\hline $\begin{array}{l}\text { Total porosity } \\
\text { Permeability }\end{array}$ & $\begin{array}{l}34 \\
34\end{array}$ & $\begin{array}{l}19.8-48.3 \\
0.00005-0.6\end{array}$ & $\begin{array}{l}38.8 \\
.006\end{array}$ & $\begin{array}{l}37.7 \\
.05\end{array}$ \\
\hline \multicolumn{5}{|c|}{$\begin{array}{l}\text { Clayey tuff and clayey sediments } \\
\text { [Some clayey volcanic breccia] }\end{array}$} \\
\hline $\begin{array}{l}\text { Effective porosity } \\
\text { Permeability }\end{array}$ & $\begin{array}{l}32 \\
38\end{array}$ & $\begin{array}{c}1.8-21.6 \\
0.000002-0.4\end{array}$ & $\begin{array}{l}10.4 \\
.00006\end{array}$ & $\begin{array}{l}11.0 \\
.02\end{array}$ \\
\hline
\end{tabular}

The interstitial permeability is very small; median values of the clayey and zeolitized cores, respectively, are 0.00006 and $0.006 \mathrm{gpd}$ per sq ft. Median values of porosity are 10 and 39 percent, respectively.

In general, core analyses indicate that the interstitial porosity and permeability of the tuff aquitard beneath the valleys are similar to those of the tuff aquitard in the tunnels and shafts. Therefore, the hydraulic tests of the aquitard beneath Yucca Flat and other valleys will probably reflect principally the transmissibility of water-bearing fractures (fault zones?) that cut the rock.

The basal 10 to 440 feet of the tuff aquitard beneath Yucca Flat commonly consists of clayey tuff and (or) clayey tuffaceous sediments, rather than of massively zeolitized rocks. Range in thickness of this clayey interval in 22 holes that reached the pre-Tertiary rock in Yucca Flat is shown in the following tabulation:
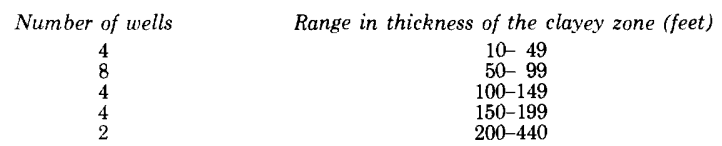

In five additional holes, the basal clayey zone is absent or its presence is doubtful. The clayey basal part of the aquitard was verified through use of electric logs supplemented by X-ray analyses of cores and cuttings. R. D. Carroll, U.S. Geological Survey (written commun., July 1963), compared electrical resistivities in selected holes with X-ray analyses of cores and noted the follow- 
ing general relationship: Tuffs and tuffaceous sediments with electrical resistivities of $20 \mathrm{ohm}$-meters or less have clay contents of 50 percent or more; resistivities of 10 $\mathrm{ohm}$-meters or less indicate clay contents of 70 percent or more. X-ray analyses indicate that the clays consist chiefly of montmorillonite, illite, and mixed-layer minerals.

\section{HYDRAULIC TESTS}

The specific capacities for 32 intervals of the tuff aquitard in 9 test holes were determined by bailing, swabbing, or injection tests. Inflatable packers identical with those used to test the lower carbonate aquifer were used to isolate most of the intervals tested. Seven of these holes (83-69a, 84-68, 84-68c, 87-62, 87-67a, $88-63 \mathrm{~b}$, and 88-66) are in or adjacent to Yucca Flat; one $(73-66)$ is at the head of Rock Valley, and one (74-57) is in western Jackass Flats.

The values of specific capacity range from 0.01 to 3 gpm per foot of drawdown per 1,000 feet of penetration. The mean value is $0.5 \mathrm{gpm}$ per foot of drawdown per 1,000 feet, and the median is 0.09 gpm per foot of drawdown per 1,000 feet. The higher specific capacities and the mean, which is disproportionately affected by high values, are above the arbitrary limit $(0.1 \mathrm{gpm}$ per $\mathrm{ft}$ of drawdown per $1,000 \mathrm{ft}$ ) established previously for aquitards. Short-term packer tests, however, affect a relatively small volume of rock. By analogy with the rapid drainage of fractures in underground openings in the tuff aquitard, the authors believe that the relatively high specific capacities are very localized. The median value is within the range defined for aquitards and suggests a coefficient of transmissibility of only 100 to 200 gpd per ft.

Transmissibility of the tuff aquitard as measured in wells is probably controlled by fractures, because the interstitial permeability is usually too low to permit continuous bailing or swabbing. Direct evidence of such control is available from test well 87-62. The upper 2,000 feet of that hole was drilled with cable tools and was dry to a depth of 560 feet. During drilling through the tuff aquitard at that depth, water suddenly entered the hole and rose to a depth of 412 feet below the surface. The sudden entry of water into the bore probably reflects the intersection of a partially open fault zone or joint, similar to those observed in the underground workings. Some wells may eventually penetrate fault zones of high transmissibility, as in the tunnels. Highly fractured zones, if penetrated in wells, may also be poorly connected and readily dewatered, as were those penetrated by the underground workings.

Because of the poor hydraulic connection of the waterbearing fractures observed in the tunnels, regional movement of ground water through the tuff aquitard is probably controlled chiefly by the interstitial permeability of the tuff.

\section{LAVA-FLOW AND O'THER MINOR AQUITARDS}

The dacitic lava flows of the Wahmonie Formation constitute the lava-flow aquitard (table 1). These lava flows, aggregating as much as 4,000 feet in thickness, occur chiefly northwest of the Cane Spring fault zone (fig. 31 ; individual flows are as much as 800 feet thick. The extent of these lavas is shown on maps by Poole, Elston, and Carr (1965) and by Ekren and Sargent (1965).

Knowledge of the hydrologic properties of these rocks is limited to data from a few core holes and an underground chamber in Wahmonie Flat, about $1 \frac{1 / 2}{2}$ miles northwest of Cane Spring (fig. 31). The core holes penetrated a perched zone of saturation at depths of about 80 to 166 feet below the surface (alt. 3,924 to 4,042 ft above mean sea level).

The interstitial permeability of the dacitic lava flows is extremely low. The interstitial permeability to nitrogen gas was determined for five dacite core samples under confining pressures ranging from 14.7 to $2,000 \mathrm{psi}$ (pounds per square inch) (Johnson and Ege, 1964). Under 1 atmosphere confinement (14.7 psi), four intact specimens had permeabilities less than 0.1 millidarcy, while one core with a small fracture had a permeability of 1.7 millidarcies. Under higher confining pressures the permeabilities of the intact cores were reduced by as much as three orders of magnitude, but the effect on the fractured core was slight. Based on these data the interstitial permeability to water should not exceed 0.0018 to $0.03 \mathrm{gpd}$ per square $\mathrm{ft}$ (for the fractured core). Under the confining pressures at depths of several thousand feet, the permeability may be much lower. The interstitial porosity of the dacite samples ranges from $\mathbf{5 . 7}$ to 14.1 percent.

Ground water is transmitted through the lava flows chiefly along fractures. From observations on the inflow of water from fractures into the chamber, C. E. Price (oral commun., 1963) concluded that the coefficient of transmissibility of the lava flow was probably less than 500 gpd per ft and could be a fraction of this quantity.

Additional evidence that the gross transmissibility of the Wahmonie lava flows is very low is the perched water in these rocks.

Two granitic stocks of probable Mesozoic age in northcentral and northwestern Yucca Flat also constitute aquitards of minor areal extent. A detailed discussion of the occurrence of ground water in the Climax stock in north-central Yucca Flat was presented by Walker (1962). The hydraulic characteristics of the Gold Meadows stock in northwestern Yucca Flat are probably similar to the intrusive rocks of the Climax stock. 


\section{DISTRIBUTION AND SATURATED THICKNESS OF AQUIFERS AND AQUITARDS}

The complex structural and erosional history of Tertiary and pre-Tertiary rocks has resulted in a highly variable lateral and vertical subsurface distribution of hydrogeologic units. Because of Tertiary normal faulting and the pre-Tertiary large-scale folding, faulting, and erosion, the structural relief on many of the hydrogeologic units commonly ranges from 2,000 to 6,000 feet within a few miles and as much as 500 feet within 1,000 feet. Thus, a fully saturated hydrogeologic unit at depths of several thousand feet below the structurally deepest part of an intermontane valley may be only partially saturated near the margins of that valley. The same unit (unsaturated) may cap a mesa that rises 2,000 feet above the valley floor, or owing to erosion, it may be completely absent in outcrop.

In addition to the complex structural disposition of the hydrogeologic units, the depth to water table also markedly influences the saturated thickness of most of the Cenozoic aquifers and aquitards beneath the valley floors. In valleys with relatively shallow water tables (less than $500 \mathrm{ft}$ ), all the hydrogeologic units except the uppermost few hundred feet of the valley-fill aquifer are usually saturated in the subsurface. However, in valleys with relatively deep water tables (500 to $2,000 \mathrm{ft}$ ), both the vertical disposition of the rocks and the depth to water influence the saturated extent and the thickness of the younger hydrogeologic units. In such valleys, the Cenozoic hydrogeologic units are commonly unsaturated beneath the margins of the valleys, and some units may be partially unsaturated even beneath the structurally deepest part of the valleys.

The effect of geologic structure and depth to water table on disposition and saturated thickness of the hydrogeologic units is best illustrated at Yucca Flat.

\section{YUCCA FLAT}

The general structural setting of Yucca Flat is shown on plate 2. The fence diagram (pl. $2 A$ ) shows areal and subsurface distribution of 8 of the 10 geohydrologic units (table 1).

The major features illustrated are the following:

1. The lower clastic aquitard forms the hills bordering Yucca Flat on the northeast. These strata dip generally southwestward and form the southwest limb of the Halfpint Range anticline (structural feature 6 on pl. 1).

2. The lower carbonate aquifer occurs beneath the ridges bordering the valley on the east and the southeast and beneath the eastern two-thirds of the valley floor. The aquifer crops out or occurs at relatively shallow depths beneath ridges that rise as much as 1,300 feet above the valley floor; it is irregularly downfaulted to depths of 1,500 to 4,000 feet beneath the valley floor.

3. The upper clastic aquitard is the principal hydrogeologic unit beneath the western one-third of the valley and beneath the ridges bordering the valley on the west. These strata are bent into several large north-trending folds and have been thrust eastward over the lower carbonate aquifer along the relatively high angle Tippinip thrust fault.

4. The upper carbonate aquifer also occurs in the hills bordering the valley on the west, but its areal and subsurface extent is small.

5. Klippen of the lower carbonate aquifer locally overlie both the upper clastic aquitard and the upper carbonate aquifer (pl. $2 A$, fences $\mathrm{C}-2$ to $\mathrm{C}-3$, $\mathrm{D}-2$ to $\mathrm{D}-3, \mathrm{E}-1$ to $\mathrm{E}-3$, and $\mathrm{F}-1$ to $\mathrm{F}-3$ ).

6. The general areal distribution of the pre-Tertiary rocks is controlled by pre-Tertiary structure, probably the Halfpint Range anticline (pl. 1), and by pre-mid-Tertiary erosion. The Tertiary block faulting markedly affected the vertical distribution of the miogeosynclinal rocks but not their general areal distribution.

7. The tuff aquitard and the welded-and bedded-tuff aquifers, which crop out along the margins of the valleys at levels as much as 3,000 feet above the valley floor, are irregularly downfaulted to depths as much as 3,500 feet beneath the valley floor. The Tertiary block faulting is a major control on both the areal and the vertical distribution of these units.

8. The tuff aquitard generally separates welded-tuff, bedded-tuff, and valley-fill aquifers from the lower carbonate aquifer.

9. In general, the structurally deepest part of Yucca Flat lies along the central to the eastern one-third of the valley; the western one-third of the valley is underlain by the upper clastic aquitard (or by klippen of the lower carbonate aquifer) at relatively shallow depth.

10. The valley-fill aquifer occupies the troughs formed by the block faulting of the older rocks. However, the valley fill is not necessarily thickest in the structurally deepest part of the valley. Along fence E-2 to E-3 of plate $2 A$, a gravity survey indicates that the lower carbonate aquifer occurs nearly 3,500 feet below the valley floor at the site of well 81-69 where the valley fili is about 700 feet thick. On the other hand, beneath well 81-67 the valley fill is nearly twice as thick where the carbonate aquifer is probably buried only about 2,000 feet beneath the valley floor. A similar relationship is seen along fence D-2 to D-4. 
The degree of folding and faulting of the hydrogeologic units is considerably greater than shown diagrammatically on plate $2 A$. Imbricate thrust faults of relatively minor displacement are common in outcrop within the lower and the upper clastic aquitards and may also be present within the lower carbonate aquifer. In addition, the subsurface contacts of the hydrogeologic units beneath the valley floor are depicted as relatively smooth surfaces on the fence panels, but the degree of stratigraphic offset and the frequency of faulting of the Cenozoic rocks beneath the valley floor are probably as great as those depicted along the fence panels near the margins of the valley. The difference in the detail shown in the panels is due to the sources used in their construction. The panels near the margins of the valleys are based on areal mapping, whereas the panels across the valley floor are based only on well control and on structure-contour maps constructed from gravity surveys and well data.

The influence of depth to water table on saturated thickness and extent of the hydrogeologic units is illustrated by plate $2 A$ and $B$. Plate $2 B$ is a generalized geologic map of Yucca Flat at an altitude of 2,400 feet. This level was chosen because it is the approximate altitude of the potentiometric surface in the lower carbonate aquifer (and overlying Cenozoic hydrogeologic units) beneath the eastern two-thirds of the valley. The contacts may be in error by as much as 1 mile, but such an error does not detract from the major purpose of plate $2 A$ and $B$, which show the following:

1. The lower clastic aquitard is the chief hydrogeologic unit within and above the zone of saturation beneath the hills bordering Yucca Flat on the northeast.

2. The upper clastic aquitard is the chief hydrogeologic unit within and above the zone of saturation beneath the ridges bordering the valley on the west.

3. The lower carbonate aquifer lies within the zone of saturation and is under unconfined conditions beneath most of the low ridges bordering the valley on the east and southeast. Beneath much of the eastern two-thirds of the valley, on the other hand, the lower carbonate aquifer is also present within the zone of saturation but is under confined, artesian, conditions. Beneath this area of confinement, the tuff aquitard directly overlies the aquifer. The saturated thickness of the lower carbonate aquifer, ranging from a few tens to hundreds of feet in the immediate vicinity of the lower clastic aquitard (fence C-3 to C-4 and D-4 to D-5 of pl. $2 A$ ), probably increases to more than 10,000 feet toward the center of the valley. This significant increase in thickness reflects the stratigraphic sequence of these westward dipping rocks. The carbonate rocks at the water table along the east edge of fence D-3 to D-5 of plate $2 A$, are probably of Middle Cambrian age; those penetrated by well 83-69a are of Ordovician age (Antelope Valley Limestone); whereas those tapped by well 84-68d are of Devonian(?) age. Thus, near the east edge of this fence panel the saturated thickness of the lower carbonate aquifer probably ranges from a few hundred feet to 1,000 feet; at well 83-69a saturated carbonate strata may aggregate as much as 10,000 feet in thickness, and beneath well $84-68 \mathrm{~d}$ it possibly aggregates as much as 14,000 feet.

4. The upper carbonate aquifer is saturated below an altitude of 2,400 feet only beneath Syncline Ridge and a small area in the vicinity of well 83-66c. Because the potentiometric level in the western one-third of the valley ranges in altitude from 2,900 to more than 3,700 feet, the actual saturated extent of this aquifer beneath and adjacent to Syncline Ridge is probably twice that shown on the map; its saturated thickness may approach 2,000 feet.

5. The tuff aquitard is partly saturated over most of the eastern two-thirds of the valley; it is fully saturated only beneath the central part of the valley (and possibly in two small areas in the north-central part of the valley), where it is overlain by the saturated welded- and bedded-tuff aquifers. (Partly saturated zeolitized tuff also occurs beneath areas of high potentiometric surface within the upper clastic aquitard; these areas are not shown on plate $2 B$. The saturated thickness of the aquitard probably ranges from a few tens of feet to 1,500 feet.

6. The welded-tuff and bedded-tuff aquifers are fully saturated only where they are overlain by saturated valley fill; namely, in the center of the valley and in the immediate vicinity of well 86-67. Elsewhere they are partly saturated or unsaturated. Where fully saturated, these two hydrogeologic units may be as much as 1,000 feet thick.

7. Although the valley fill underlies most of the valley floor to depths of hundreds of feet, only in the central part of the valley and in the vicinity of well $86-67$ is it thick enough to extend below the water table and be within the zone of saturation. The saturated thickness of the valley fill is at least 270 feet at well 83-68, but it probably does not exceed 400 feet at this site or elsewhere beneath the central part of the valley.

Plate $2 A$ and $B$ are intended only as qualitative pictures of aquifer disposition and saturated thickness. Isopach maps of the valley fill and of the welded tuffs composing the welded-tuff aquifer have been prepared by Livingston Chase (written commun., May 1965) and by Harley Barnes (unpub. data) of the U.S. Geological Survey. These maps may be studied for more detailed 
information on the saturated thickness of the Cenozoic aquifers.

The scant distribution of saturated valley-fill, weldedtuff, and bedded-tuff aquifers beneath Yucca Flat is largely due to the great depth to water in this valley. Because of the relatively great thickness of the lower and upper clastic aquitards and the lower carbonate aquifer (in comparison with the younger hydrogeologic units), the depth to water table is usually not an important factor in determining the extent or saturated volume of these Paleozoic rocks, as it is with the Cenozoic strata. Locally, where the lower carbonate aquifer occurs in thin klippen overlying the upper clastic aquitard, the depth to water plays an important role in controlling the saturated extent of these rocks.

\section{OTHER VALLEYS}

The surface and the subsurface extent of the hydrogeologic units and their thickness vary from valley to valley because of the complex structural and erosional history of these rocks. Gravity surveys of western Emigrant Valley, Frenchman Flat, Jackass Flats, southern Indian Springs Valley, Mercury Valley, and the Amargosa Desert were made by Messrs. D. L. Healey and C. H. Miller, U.S. Geological Survey (written commun., 1965), during the period 1961-64. These surveys, plus two deep-drill holes in Frenchman Flat (75-73 and 76-70) and one in Jackass Flats (74-57), indicate that the relief on the buried pre-Tertiary rocks is as much as several thousand feet. The gravity surveys and the outcrops of pre-Tertiary rock on the valley floors also indicate that the depth of burial of the pre-Tertiary rocks is not necessarily related to present topography; buried ridges of Tertiary or pre-Tertiary rocks commonly underlie parts of the valley floors at depths of a few tens to hundreds of feet. Therefore, by analogy with Yucca Flat, the structural relief on the Cenozoic hydrogeologic units beneath the valleys cited must also range from hundreds of feet to more than 2,000 feet beneath the valley floors and must reflect to a large degree the relief on the preTertiary rocks. Thus, in those valleys with relatively deep water tables (Frenchman Flat, Jackass Flats, and Mercury Valley) the Cenozoic hydrogeologic units are probably saturated or partly saturated only beneath the structurally deepest parts of the valleys. In those valleys with relatively shallow water tables (western Emigrant Valley, southern Indian Springs Valley, and the Amargosa Desert), all the hydrogeologic units except the uppermost several tens to few hundreds of feet of the valley-fill aquifer are probably fully saturated. Details on the hydrogeologic setting of the valleys cited are presented in other parts of this report.

The following generalizations about the regional disposition of the hydrogeologic units appear valid:
1. The lower carbonate aquifer occurs alternately under confined (artesian) and unconfined (water-table) conditions. Beneath the deepest parts of most intermontane basins, this aquifer is confined by the saturated tuff aquitard, whereas beneath ridges it is unconfined. Along valley margins (or beneath midvalley structural highs), it may be confined or unconfined depending upon the structural setting and the depth to water table.

2. The lower carbonate aquifer is saturated throughout the study area except beneath or in the vicinity of outcrops or buried structural highs of the lower clastic aquitard.

3. The tuff aquitard generally separates the welded-tuff and valley-fill aquifers from the lower carbonate aquifer, particularly in the structurally deep parts of the intermontane basins. However, in the vicinity of buried pre-Tertiary structural highs, the Cenozoic aquifers locally may be in direct contact with the lower carbonate aquifer; this would occur in areas where the tuff aquitard was never deposited or was eroded prior to the deposition of the strata comprising the Cenozoic aquifers.

4. In valleys with deep water tables (500 to $2,000 \mathrm{ft}$ ) the tuff aquitard may surround as well as underlie the Cenozoic aquifers at the altitude of the water table.

5. Because of the relatively great thickness of the lower and upper clastic aquitards and the lower carbonate aquifer (in comparison with the younger hydrogeologic units), the depth to water table is usually not an important factor in determining the exter $t$ or saturated volume of these rocks, as it is witn the Cenozoic strata.

\section{MOVEMENT OF GROUND WATER}

Ground-water movement within the study area may be classified as follows: (1) Movement of perched water; (2) intrabasin movement of water, including semiperched water; and (3) interbasin movement of water.

The definition of perched ground water used in this report follows that of Meinzer (1923, p. 40), who stated: "Ground water is said to be perched if it is separated from an underlying body of ground water by unsaturated rock. Perched water belongs to a different zone of saturation from that occupied by the underlying ground water." Perched ground water should not be confused with semiperched ground water, which Meinzer (1923, p. 41) defined: "Ground water may be said to be semiperched if it has greater pressure head than an underlying body of ground water, from which it is, however, not separated by any unsaturated rock $* * *$. Semiperched water, like perched water, is underlain by a 
negative confining bed of either permeable or impermeable type." At Nevada Test Site and vicinity, semiperched water, as well as perched water commonly occurs within both aquitards (namely within Meinzer's "negative confining bed") and aquifers.

Perched water commonly occurs in foothills and ridges flanking the basins and is water in transit to the regional water table. The tuff aquitard is the principal hydrogeologic unit in which the perched water occurs at Nevada Test Site.

The movement of water between the Cenozoic and the Paleozoic aquifers and aquitards beneath a valley is called intrabasin movement of ground water. In Yucca and Frenchman Flats, ground water in the Cenozoic hydrogeologic units is semiperched and moves principally downward into the underlying lower carbonate aquifer. In the southern Amargosa Desert and in southern Indian Springs Valley, ground water in the Cenozoic rocks is derived through upward leakage of water from the underlying lower carbonate aquifer. In these areas, water in the lower carbonate aquifer has higher head than that in the Cenozoic rocks.

At depths as much as several thousand feet beneath the valley floors and at shallower depths beneath the flanking ridges, ground water occurs within the preTertiary aquifers and aquitards. This ground water generally moves laterally beneath the valleys and their bordering ridges. This lateral movement over wide areas is called interbasin movement of ground water. Such movement is possible in south-central Nevada, principally because of the widespread occurrence of the lower carbonate aquifer beneath most of the valleys and ridges within the study area.

In test wells at Nevada Test Site, water levels either declined, rose, or remained unchanged as the holes were deepened. Such water-level changes can be interpreted to reflect more than one hydrogeologic setting, and such interpretations were evaluated during construction of the potentiometric maps.

Declining heads with increasing depths are attributed to at least three causes: (1) penetration of an unsaturated zone beneath a perched zone; (2) energy losses in areas of dominantly vertical movement, as is common in recharge areas or areas with semiperched ground water; and (3) penetration of an aquifer of the same or greater transmissibility than an overlying aquifer but with a lower discharge point. Rises in water level with increases in depth are commonly due to penetration of zones of higher potential energy in discharge areas or on the upgradient side of hydraulic barriers.

\section{PERCHED GROUND WATER}

Perched ground water feeds several small springs (less than $5 \mathrm{gpm}$ ) at Nevada Test Site and numerous small- to moderate-yield springs ( 5 to more than $400 \mathrm{gpm}$ ) in the
Spring Mountains and the Sheep Range. The springs commonly emerge from consolidated rock within the mountains or ridges flanking valleys and are characterized by highly variable discharge and by variable temperature, usually less than $21.0^{\circ} \mathrm{C}$. Perched ground water has also been observed and studied within some of the underground workings driven into Rainier Mesa in northwestern Yucca Flat and into the Climax stock of north-central Yucca Flat. The perched springs should be distinguished from springs that emerge from the valley-fill and the lower carbonate aquifers at low altitudes on the borders or floor of some valleys. These valley-level springs represent discharge points of a regional zone of saturation; they are characterized by high and uniform discharge and uniform temperatures that range from $24.0^{\circ} \mathrm{C}$ to $35.0^{\circ} \mathrm{C}$. Some of the springs discharging at intermediate and low altitudes within the Spring Mountains may actually be semiperched at certain times of the year, or even all year, rather than perched. For the purposes of this report these springs are all classified as perched.

\section{NEVADA TEST SITE}

Perched ground water at the Nevada Test Site occurs principally within the aquitards underlying ridges namely, within the widespread tuff aquitard and the lava-flow aquitard.

Nine perched springs occur within Yucca Flat, Frenchman Flat, and Jackass Flats. Moore (1961) reported that only two, Whiterock and Cane Springs have discharges exceeding $1 \mathrm{gpm}$. Thordarson's (1965) observation that all the springs in Yucca Flat discharge from the tuff aquitard is also true for the few springs in Frenchman Flat and Jackass Flats. Perched water occurs within the tuff aquitard and does not emerge from the bedded-tuff aquifer or the welded-tuff aquifer, which overlie the aquitard. Pavits Spring in southwestern Frenchman Flat (fig. 31) may be an exception. Five of six springs in Yucca Flat emerge from the tuff aquitard where it directly overlies the upper clastic aquitard; only at one spring (dry since 1958) does the aquitard immediately overlie the carbonate aquifer. The springs in Yucca Flat occur at altitudes of 5,050 to 6,250 feet above mean sea level.

In the underground workings beneath Rainier Mesa, the perched water occurs only within the tuff aquitard. The tunnels penetrating the bedded-tuff aquifer are dry. Perched water in the tunnels occurs in poorly connected fractures, chiefly fault zones of minor stratigraphic offset. Figure 30, modified after Thordarson (1965, fig. 4), summarizes the occurrence of perched water in fractures within the tuff aquitard beneath Rainier Mesa. Beneath the eastern two-thirds of the mesa, the dolomite underlying the zeolitized tuff is unsaturated; the ground water within the fractures is perched. Beneath the 


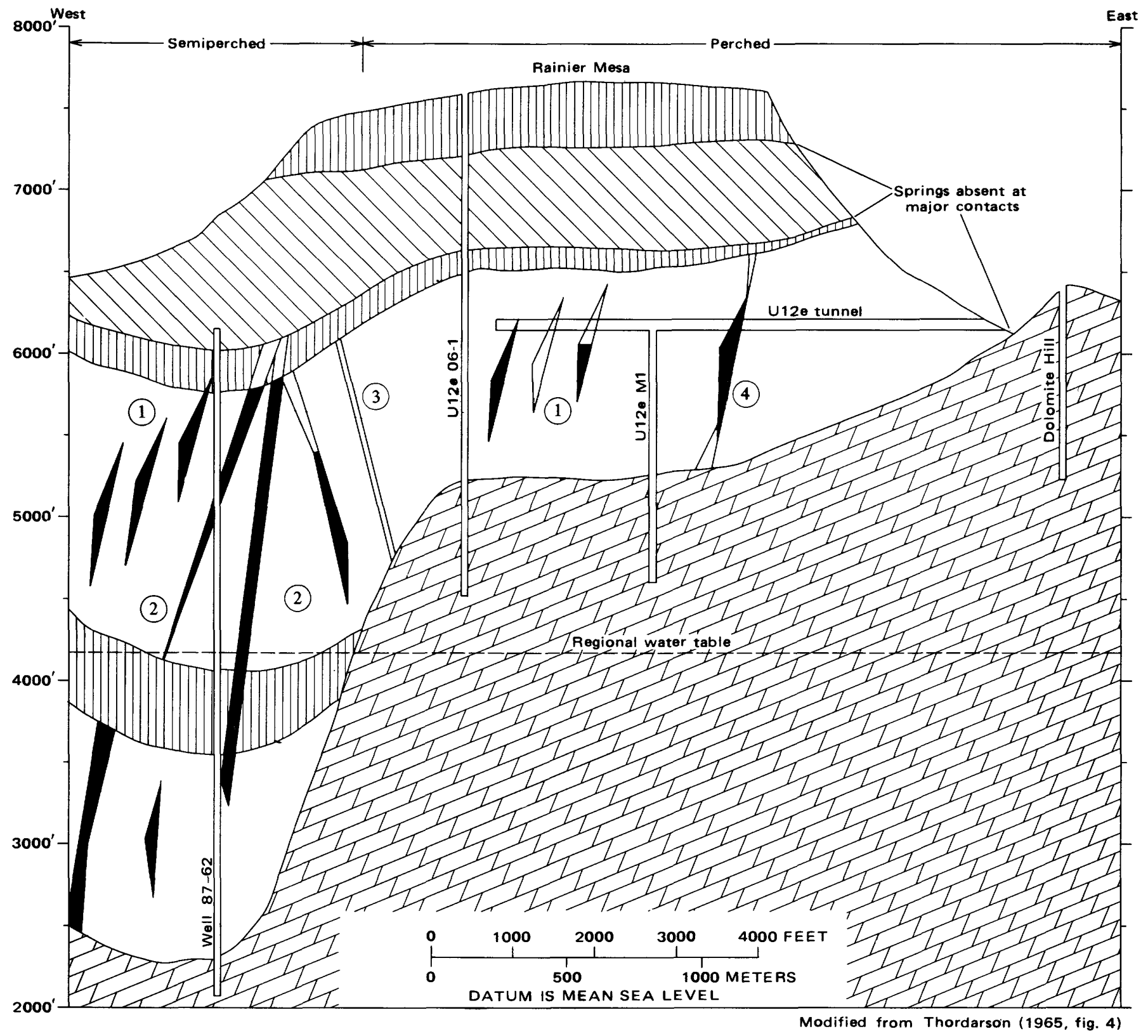

EXPLANATION

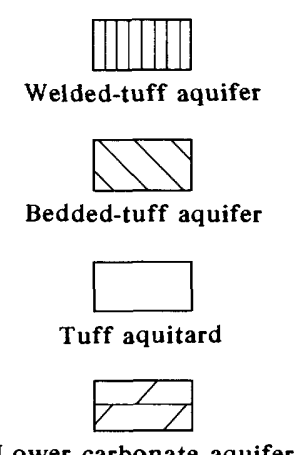

Lower carbonate aquifer

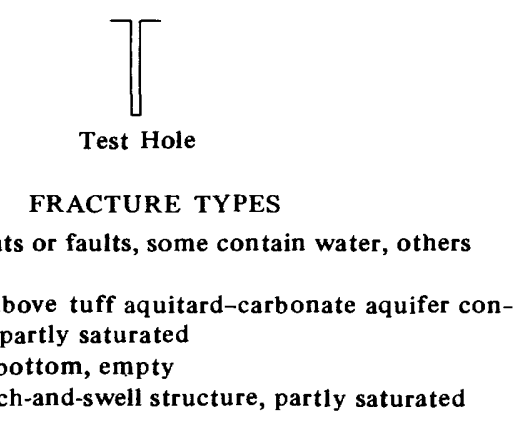

FIGURE 30. - Diagrammatic section showing perched and semiperched ground water in the tuff aquitard of Rainier Mesa. Vertical exaggeration about $\times 2$. 
western one-third of the mesa, water in the fractures is semiperched, because the aquitard extends beneath the potentiometric surface of the lower carbonate aquifer.

The top of the tuff aquitard at Rainier Mesa is about 6,600 feet above mean sea level at the east edge of the mesa, or about 800 feet beneath the top of the mesa. The perched water table in fractures within the aquitard is between 6,033 and 6,184 feet above mean sea level in the east-central part of the mesa (Thordarson, 1965, p. 34), or about 1,200 to 1,400 feet beneath the mesa surface. This perched water table is in turn about 2,000 feet above the water table within the underlying lower carbonate aquifer. Immediately south of the mesa at the site of well 87-62 (fig. 30), the top of the aquitard is about 5,931 feet above mean sea level and about 225 feet beneath the land surface. The perched water table here is about 5,746 feet above mean sea level, or only 410 feet beneath the land surface (altitude 6,156 ft). The perched water level at this site is about 1,560 feet above the potentiometric surface within the lower carbonate aquifer and about 1,030 feet above the potentiometric surface within a welded tuff which is within the tuff aquitard (fig. 30).

Perched water also occurs within the tuff aquitard in southwestern Frenchman Flat in the vicinity of Cane Spring, Pavits Spring, and test wells $73-66$ and $73-68$ (fig. 31). For example, well 73-66 began in the tuff aquitard and was drilled through 3,137 feet of the aquitard. Perched ground water stood at a depth of 77 feet below the surface when the hole was 603 feet deep. The static water level within the lower carbonate aquifer (in the interval $3,137-3,400 \mathrm{ft}$ ) was 1,735 feet below the surface.

At test hole 73-68 (fig. 31), water occurs within the tuff aquitard at a depth of $518 \pm 2$ feet below the surface, or at an altitude about 600 feet higher than the regional potentiometric surface east and west of the site.

Northwest of Cane Spring, perched ground water occurs within the lava-flow aquitard. The lava-flow aquitard crops out or occurs within a few tens of feet of the surface, and the perched water is within 80 to 166 feet of the surface, or at an altitude of 3,924 to 4,042 feet above mean sea level. A brief discussion of this perched water was presented by Johnson and Ege (1964).

The occurrence of perched water in Climax stock and surrounding carbonate rocks in northern Yucca Flat was described by Walker (1962) and by Schoff and Winograd (1961).

Perched water is not known to occur within the aquifers or aquitards beneath Yucca Flat, Frenchman Flat, or Jackass Flats. Occurrence of shallow ground water beneath these valleys reflects the presence of either the upper or the lower clastic aquitards at very shallow depth or the damming of water within a Cenozoic aquifer by the aquitards.
Based on the preceding described or cited examples, the occurrence of perched water at the Nevada Test Site may be summarized as follows:

Where tuff, lava-flow, or granitic aquitards occur at or near the surface, perched water usually occurs at shallow depths - from about 80 feet at well 73-66 to as much as 410 feet at well 87-62. Where the aquitard lies deep beneath the surface, as at Rainier Mesa and at test well $73-68$, the perched water table occurs at depths of about 520 to 1,400 feet beneath the surface. Similarly, where the top of the aquitard is at a high altitude, as at Rainier Mesa, the perched water table is also at a high altitude $(6,000-6,200 \mathrm{ft})$; whereas in western Frenchman Flat, where the aquitard crops out at low altitudes $(3,900$ to $4,100 \mathrm{ft}$ ), the perched water occurs at lower altitudes.

Areal differences in precipitation probably do not cause these wide variations in vertical position of the perched water tables, because even at lower altitudes, where precipitation is at a minimum, fractures in the aquitards may be saturated nearly to the surface. Conversely, beneath Rainier Mesa, which receives the maximum recorded precipitation at Nevada Test Site (about 8 in. annually), the fractures in the upper 400 feet of the aquitard generally are unsaturated. The preferred explanation for the variation in depth to and altitude of the perched water beneath the ridges and hills flanking the valleys follows.

The aquitards underlying the ridges or buried beneath the margins of the valley floor are blocks of poorly permeable rock surrounded and underlain by strata of much higher permeability. When drainage of recharge from the aquitard to the surrounding aquifers is retarded, perched ground-water mounds develop within the aquitards. The altitude of the mounds is largely a function of the vertical disposition of the aquitards.

Perched ground water may be found locally throughout the Nevada Test Site wherever aquitards compose ridges or hills that lie above the regional zone of saturation. Thordarson's work (1965) shows, however, that the occurrence of such water is erratic and depends largely upon the interconnection of the fractures within the aquitard and, in turn, their connection with the underlying aquifers.

\section{SPRING MOUNTAINS}

Occurrence, geologic control, and discharge of springs in the Spring Mountains (pl. 1) was described by Maxey and Jameson (1948) and by Hughes (1966). Maxey and Jameson presented data that illustrate the highly variable discharge of several major springs. Hughes principally discussed the geologic controls localizing the springs.

Most springs within the Spring Mountains issue from the lower carbonate aquifer, which makes up most of the range and its highest part. Perhaps two dozen springs 
also discharge from the lower clastic aquitard in the northwestern quarter of the range and from Mesozoic strata, which form part of the southeastern end of the range. Discharge of the more than 60 springs in the area ranged from a few gallons per minute to more than 16,000 gpm (Maxey and Jameson, 1948, fig. 8); however, only about eight of these springs discharged more than $100 \mathrm{gpm}$, and the majority discharged less than $10 \mathrm{gpm}$. Between spring and fall, discharges of several high-yield springs apparently differ by more than an order of magnitude. The 1964 summer water temperatures reported by Hughes ranged from $6.0^{\circ}$ to $21.0^{\circ} \mathrm{C}$ and, in general, varied inversely with altitude.

In the summer of 1964 Hughes measured a total discharge of about $1,430 \mathrm{gpm}$ for the springs within or on the edge of the $\{$ pring Mountains. Of the total discharge, about $1,300 \mathrm{gpm}$ discharged from the lower carbonate aquifer, which forms the highest part $(6,000-12,000 \mathrm{ft})$ of the Spring Mountains. About $100 \mathrm{gpm}$ discharged from sandstone (Aztec Sandstone) of probable Jurassic age, which crops out along the southeastern edge of the mountains at altitudes ranging from 4,000 to 6,000 feet. Only $30 \mathrm{gpm}$ discharged from the lower clastic aquitard, which underlies the northwestern quarter of the mountain range at altitudes generally above 7,000 feet. Most of this discharge came from quartzite of the Stirling Quartzite and Johnnie Formation; little or none was discharged from shale or siltstone units.

Geologic control of the springs varies. Most of the carbonate-rock springs described by Hughes are probably localized by faults or joints, although three of the high-yield springs (Deer Creek Spring, Lee Spring, and Trout Springs) reportedly emerge from small caverns. The springs discharging from the lower clastic aquitard are probably chiefly controlled by faults. The discharge from two of the major springs (Cold Creek Spring and Willow Spring) may be due to damming of the lower carbonate aquifer by the lower clastic aquitard, which crops out near the springs (fig. 33). Springs in the thick and crossbedded Aztec Sandstone discharge at the contact with the underlying relatively impermeable shales of the Triassic Chinle Formation.

\section{INTRABASIN MOVEMENT}

Ground water within the valley-fill aquifers of the intermontane basins of the Southwest is commonly described as moving laterally from recharge areas in the flanking mountains toward discharge areas in playas, streams, or adjacent valleys. In addition, Tertiary and pre-Tertiary bedrock underlying and flanking the valley fill has commonly been considered relatively impermeable in comparison with valley fill. At the Nevada Test Site, the valley-fill aquifers within Yucca and Frenchman Flats are surrounded by Tertiary and older rocks; yet these valleys contain no "wet playas" playas representing the intersection of the land surface and the water table - or perennial streams. On the contrary, depth to the water table beneath these valleys ranges from 700 to 2,000 feet below the valley floors. The great depth to water in these structurally and topographically closed basins suggested to some geologists (in the early 1950's) that the valley-fill and older aquifers had never filled with ground water. However, this early hypothesis is unreasonable because the valley-fill aquifer in adjacent basins - western Emigrant Valley and the Amargosa Desert - is nearly saturated. Moreover, widespread lake deposits indicate that most of the valleys in the study area contained lakes during the Pleistocene pluvial periods.

Test drilling has shown that the deep water table in Yucca and Frenchman Flats is primarily due to the drainage of water from the valley-fill and older Cenozoic aquifers into the underlying and surrounding lower carbonate aquifer. In Yucca and Frenchman Flats, this intrabasin movement of ground water is downward from the younger into the older aquifers; that is, the water is semiperched. In other valleys, such as the Amargosa Desert, southern Indian Springs Valley, and perhaps eastern Jackass Flats, intrabasin movement is upward.

\section{YUCCA FLAT}

Ground water beneath Yucca Flat occurs within valley-fill, welded-tuff, bedded-tuff, and lower carbonate aquifers and within tuff, upper clastic, and lower clastic aquitards (pl. $2 A$ and $B$ ).

The depth to water generally ranges from 535 to 1,915 feet beneath the surface, or from an altitude of 2,555 to 3,755 feet. Beneath the eastern two-thirds of the valley, the part underlain by the lower carbonate aquifer (pl. $2 B$ and $C$ ), the range in depth to water and altitude of the water table is considerably less; here the depth to water generally ranges from 1,507 feet at well 81-69 near the south (and topographically lowest) end of the valley to 1,915 feet at well 88-66 near the north (and topographically highest) end of the valley, or from an altitude of 2,422 to 2,555 feet above mean sea level. Beneath the west-central and southwestern parts of the valley, the area underlain chiefly by the upper clastic aquitard (pl. $2 B$ and $C$ ), the zone of saturation is considerably shallower and is more than a thousand feet higher than levels in the eastern two-thirds of the valley.

Plate $2 B$ shows that the tuff aquitard is the principal Cenozoic hydrogeologic unit within the zone of saturation in the eastern two-thirds of the valley and that it is unconfined through most of its saturated extent. The welded-tuff and the bedded-tuff aquifers are saturated beneath the central and northern parts of the valley and occur under both confined and unconfined conditions. 
The valley-fill aquifer is saturated in an area of less than 10 square miles, chiefly in the central part of the valley, and it is unconfined.

Data obtained during drilling of two holes penetrating the tuff aquitard provided the first clues on movement of ground water within the Cenozoic rocks. When well 88-66 was 2,045 feet deep, the static water level was 1,915 feet beneath the surface (J. E. Moore and others, 1963). After the well had been deepened to 2,535 feet and cased (but not cemented) to 2,121 feet, the water level was 1,959 feet beneath the surface. No further physical changes were made in the well for 5 months thereafter, but the water level gradually declined another 20 feet. After penetration of the lower carbonate aquifer (Pogonip Group) at a depth of 2,550 feet, the water level in the well fell to $2,055 \pm 2$ feet (the head within the carbonate aquifer). The water level within the well remained at $2,055 \pm 2$ feet during subsequent penetration of the carbonate aquifer to a depth of 3,422 feet.

A similar decline in head was documented in well 83-69a in east-central Yucca Flat (L. R. West and William Thordarson, written commun., July 1965). At well depths of 1,875 and 1,970 feet, the measured static water level was 1,716 feet beneath the land surface. After the hole was deepened to 2,430 feet (about $70 \mathrm{ft}$ into the underlying lower carbonate aquifer), the water level dropped to 1,732 feet below the land surface. Later the hole was deepened to 2,620 feet, or 260 feet into the lower carbonate aquifer (Pogonip Group), and the static water level in the aquifer was 1,780 feet below the land surface.

A comparison of the heads in wells tapping only the Cenozoic aquifers with the head in wells tapping the lower carbonate aquifer shows a head differential between Cenozoic and pre-Cenozoic rocks throughout the eastern two-thirds of Yucca Flat. Plate $2 C$ shows that water-level altitudes in valley-fill and welded-tuff aquifers are higher than the head in the lower carbonate aquifer. Thus, ground water in the Cenozoic strata is semiperched with respect to water in the lower carbonate aquifer.

Water-level altitudes in wells tapping the Cenozoic rocks indicate one, and possibly two, hydraulic sinks along the longitudinal axis of Yucca Flat. One apparent sink is in the vicinity of wells $83-68$ and 84-68 in the central part of the valley, and the second is near well 87-67a in the north-central part of the valley (pl. $2 \mathrm{C}$ ). The static water level in wells in both the valley-fill aquifer and the tuff aquitard beneath the southern sink ranges from 2,395 to 2,406 feet (wells 83-68, 84-68, 84-68a, and 84-68c), whereas levels in surrounding wells tapping Cenozoic strata range from 2,422 to 2,455 feet (wells $81-67,81-69$, and 83-69a). In view of the documented head changes with depth, it is important to emphasize that the centrally located sink is probably not a reflection of composite static levels of different depth inter- vals. The levels in three key wells (81-69, 83-68, and $83-69$ a) were measured after penetration of only $25-170$ feet of saturated rock, and these levels probably reflect accurately the top of the semiperched water table. The apparent sink in the north-central part of the valley, however, may reflect composite static levels.

Some average hydraulic gradients toward the centrally located sink are given in table 6; also given are some average hydraulic gradients calculated for assumed predominantly vertical, rather than nearly horizontal water movement through the tuff aquitard. As expected, the lowest horizontal gradients occur between the pairs of wells in which at least one taps a Cenozoic aquifer. The computations of the average horizontal gradients are based on assumed uniform transmissibility and on the absence of hydraulic barriers between control wells. Availability of head measurements for both the tuff aquitard and the lower carbonate aquifer in the same well or in wells a few hundred feet apart permitted the estimate of possible average vertical hydraulic gradients. Both sets of gradients are used later to estimate the quantity of ground-water flow toward the sink or downward into the lower carbonate aquifer.

Because of a relatively low hydraulic gradient within the lower carbonate aquifer (from less than 0.5 to $20 \mathrm{ft}$ per mile) and the hydraulic sinks in the Cenozoic rocks, the difference in head between the Cenozoic hydrogeologic units and the lower carbonate aquifer is least near the central part of the valley and greatest along its periphery.

Ground water in the Cenozoic water-bearing units probably cannot leave Yucca Flat without passing through the tuff aquitard to the underlying and sur-

TABLE 6. - Hydraulic gradients in Cenozoic hydrogeologic units, Yucca Flat

\begin{tabular}{|c|c|c|c|}
\hline \multirow{2}{*}{$\begin{array}{l}\text { Wells between, or at, } \\
\text { which gradient } \\
\text { was calculated }\end{array}$} & \multirow{2}{*}{ Hydrogeologic unit } & \multicolumn{2}{|c|}{ Average hydraulic gradient } \\
\hline & & Feet per foot & Feet per mile \\
\hline \multicolumn{4}{|c|}{ Near horizontal flow assumed } \\
\hline $\begin{array}{l}83-69 a \\
84-68 a_{-}\end{array}$ & $\begin{array}{l}\text { Tuff aquitard } \ldots \\
\text { do }\end{array}$ & 0.006 & 32 \\
\hline $\begin{array}{l}84-68 a \\
84-68\end{array}$ & 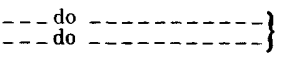 & .002 & 11 \\
\hline $\begin{array}{l}83-69 \mathrm{a}-\ldots-1 \\
84-68 \mathrm{c}-\end{array}$ & 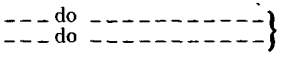 & .006 & 32 \\
\hline $\begin{array}{l}84-68 c \\
84-68\end{array}$ & 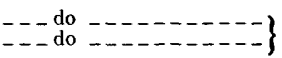 & .003 & 16 \\
\hline 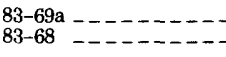 & 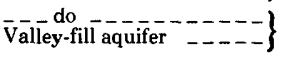 & .004 & 21 \\
\hline $\begin{array}{lll}81-67 & \ldots \\
83-68 & -\ldots-c-1\end{array}$ & $\begin{array}{l}\text { Bedded-tuff aquifer }---- \\
\text { Valley-fill aquifer } \\
\text { and }\end{array}$ & .001 & 5 \\
\hline $\begin{array}{l}81-69 \\
83-68\end{array}$ & $\begin{array}{l}\text { Welded-tuff aquifer } \\
\text { Valley-fill aquifer }----\end{array}$ & .0009 & 5 \\
\hline $\begin{array}{ll}83-68 & -1-1-1-1 \\
84-68 & -\end{array}$ & Tuff aquitard & .0007 & 4 \\
\hline \multicolumn{4}{|c|}{ Near vertical flow assumed } \\
\hline \multirow{2}{*}{\multicolumn{2}{|c|}{ 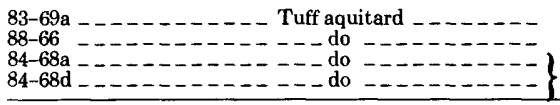 }} & $\begin{array}{r}0.1 \\
.2\end{array}$ & $\begin{array}{r}530 \\
1,100\end{array}$ \\
\hline & & .02 & 110 \\
\hline
\end{tabular}


rounding lower carbonate aquifer. It could move laterally out of the valley within the Cenozoic rocks only through a narrow strip about three-fourths of a mile wide at the south end of the valley (east of well 79-69a), where the tuff aquitard is not surrounded by the lower carbonate aquifer at the altitude of the water table. (See pl. $2 B$.) Beneath this strip, the tuff aquitard at the southern tip of Yucca Flat is hydraulically connected with the aquitard beneath northernmost Frenchman Flat. Significant lateral discharge through this strip is probably unlikely for four reasons:

1. The very low fracture transmissibility and interstitial permeability and the small cross-sectional area of the aquitard preclude movement of a significant quantity of water.

2. Underflow across this strip toward Frenchman Flat would be subjected to drainage into the lower carbonate aquifer, which borders the strip on the east and west.

3. Water levels in the Cenozoic rocks beneath central and south-central Yucca Flat indicate a northerly, rather than a southerly, hydraulic gradient.

4. The 11-foot difference in water level between the southernmost well tapping the Cenozoic rocks in Yucca Flat (well 81-69) and the northernmost well (77-71a) tapping these rocks in Frenchman Flat (pl. $2 C$ ) does not support lateral flow. Both wells tap the welded-tuff aquifer, and the apparent hydraulic gradient between them is less than 2 feet per mile; the wells are about 7.5 miles apart. However, if it is assumed that they are connected hydraulically by lateral flow, which is chiefly through the intervening strip of tuff aquitard (pl. $2 B$ ), then greater differences in water level and hydraulic gradient are expectable between these wells. The data in table 6 suggest that horizontal components of hydraulic gradient in the aquitard range from 11 to 32 feet per mile; the lowest gradient indicates that the difference in water level between these wells should be several tens of feet.

Both the apparent hydraulic sinks and the lower head in the carbonate aquifer as well as the disposition of the hydrogeologic units at the water table (pl. $2 B$ ) indicate that ground water within the Cenozoic strata beneath the eastern two-thirds of the valley cannot leave Yucca Flat without entering the lower carbonate aquifer. However, whether the ground water in the Cenozoic rocks enters the carbonate aquifer primarily through radial flow toward the apparent hydraulic sinks or leaks vertically into the carbonate aquifer throughout the valley, or both, cannot be ascertained from our present data.

The position and the nature of the centrally located hydraulic sink may be explained by one of two hypotheses or by a combination of both. The first hypotheses is that ground-water flow is centripetal toward the sink, which represents an area of relatively good hydraulic connection between the Cenozoic and Paleozoic water-bearing strata. Hydraulic connection could occur in one of two ways. An isopach map of the valley fill and a structure-contour map of the preTertiary surface prepared by Livingston Chase and W. J. Carr (written commun., Jan. and May 1965) indicate that valley-fill, welded-tuff, and bedded-tuff aquifers may locally be in direct contact with the lower carbonate aquifer near the west border of the saturated wedge of Cenozoic strata shown on plate $2 B$, particularly in the area between wells $81-67$ and 84-68. This area is crossed by the Yucca fault, a major normal fault traversing the entire length of Yucca Flat. Vertical displacement of the lower carbonate aquifer (upthrown on the west) along this fault between wells $81-67$ and $84-68$ is more than 1,000 feet. The altitude of the top of the lower carbonate aquifer ranges from 1,000 to 1,700 feet above mean sea level immediately west of the fault. East of the fault the altitude of the base of the Cenozoic aquifers is about 1,000 to 1,500 feet. Thus, the base of the welded- or bedded-tuff aquifer could be faulted against the top of the lower carbonate aquifer. This condition could result in the low water level in well 83-68, which taps the valley-fill aquifer about 3,400 feet east of the fault. Similar faulting may also explain the apparent sink in the north-central part of the valley in the vicinity of well 87-67a (pl. 2C). The structure-contour map shows a 1,000 -foot displacement (upthrown on the west) of the carbonate aquifer along the Yucca fault 3,000 feet west of the well.

If a fault-controlled hydraulic connection exists in the vicinity of the centrally located apparent hydraulic sink, it is a poor one, because the water-table altitude in well 83-68 is about 15 feet higher than the potentiometric level in the lower carbonate aquifer (alt 2,387 ft). Furthermore, the suggested direct-contact hydraulic connection via the Yucca fault does not explain the lowest Cenozoic water level in the valley, (alt 2,395 ft) in well 84-68; the well taps 600 feet of tuff aquitard. In the latitude of this well, displacement of the lower carbonate aquifer by the Yucca fault is minor (fence D-3-D-4, pl. $2 A$ ); another explanation must be sought for the water level, which is only 8 feet higher than the head in lower carbonate aquifer. Therefore, the 2,395-foot level in well 84-68 may represent a composite water level of several zones of decreasing head within the 600 feet of aquitard penetrated.

The proximity of wells $83-68,84-68$, and $87-67$ a (the wells with the lowest water-table altitudes in the central and north-central parts of the valley) to Yucca fault suggests a mode of hydraulic connection other than direct juxtaposition of the Cenozoic and Paleozoic aquifers. The fracture transmissibility of the tuff 
aquitard may have been greatly increased locally through fracturing that accompanied movement along Yucca fault. However, hydraulic tests of wells 84-68 and 87-67a did not indicate above average transmissibility of the aquitard.

Finally, neither of the two geologic conditions proposed to explain the hydraulic connection of the Cenozoic and Paleozoic strata satisfactorily explains the water level in well 81-67, which is about 3,500 feet west of the Yucca fault. This well probably taps the beddedtuff aquifer. When first drilled, it reportedly had a water-level altitude of 2,439 feet. After deepening the hole from 1,575 to 1,800 feet, the driller reported a waterlevel altitude of 2,424 feet. Thus, the prepumping levels in this well stood 29 to 44 feet higher than the lowest levels east of the.Yucca fault. Hydraulic isolation of this aquifer from the trough is difficult to explain (fence E-2 to E-3, pl. 2A) unless the Yucca fault is a hydraulic barrier.

A second hypothesis for the position and the nature of the hydraulic sinks is that the water levels in the Cenozoic units reflect valleywide downward leakage into the lower carbonate aquifer after cessation of significant recharge at the end of the last pluvial period (roughly $9,000 \mathrm{yr}$ ago). At the close of the pluvial period, the water table in both the Cenozoic rocks and the lower carbonate aquifer was probably hundreds of feet higher than present levels, and the volume of saturated Cenozoic rock was significantly greater. After reduction in recharge rate at the close of the pluvial period, two interrelated factors might have favored a more rapid decline of water table (within the Cenozoic hydrogeologic units) near the center than near the margins of the valley. First, the recharge from storm runoff or precipitation was probably greater along the margins of the valley than on the valley floor. Second, the tuff aquitard, structurally at successively higher altitudes with distance from the center of the valley, would particularly tend to retard lateral flow from the margins of the valley after the water table had dropped sufficiently to drain the overlying Cenozoic aquifers.

Data supporting the second hypothesis are available from wells 83-69a and 88-66 in the east-central and northern parts of the valley, near the margin of the presently saturated wedge of the tuff aquitard (pl. $2 B$ ). The top and the bottom of the tuff aquitard in wells 83-69a and 88-66 are several hundred feet higher than they are in more centrally located wells. The water levels in these two wells range from 31 to 131 feet higher than the water level in well 81-67, which has the next highest water level. By analogy with the occurrence of perched water in the aquitard, the high water levels in these two wells (83-69a and 88-66) may reflect extremely low transmissibility and structurally high position of the aquitard coupled with more postpluvial recharge to the aquitard than that received by the centrally located wells.

The water level in well 88-66, especially, illustrates the ability of the tuff aquitard to hold ground water above the level in the lower carbonate aquifer. Plate $2 B$ shows that the aquitard tapped by this well is surrounded on three sides by the lower carbonate aquifer and that the aquitard is less than a mile wide. Despite the opportunity for drainage in three directions, the head in the aquitard is 140 feet higher than that in the surrounding carbonate aquifer.

The second hypothesis does not necessarily rule out one or more geologically controlled hydraulic sinks, but it does not require hydraulic sinks to explain the configuration of the Cenozoic water levels. The water levels probably reflect variable vertical drainage of pluvial recharge into the lower carbonate aquifer via the tuff aquitard. The highest levels, near the margins of the present saturated zone, reflect the most recent recharge and the structurally high position of the tuff aquitard; the low levels reflect the oldest recharge and structurally lower positions of the aquitard.

Leakage from the Cenozoic rocks into the lower carbonate aquifer can be estimated using either the hypothesis of lateral flow toward a centrally located sink(s) or the hypothesis of vertical leakage throughout the valley. Assuming lateral flow through the tuff aquitard toward the central hydraulic sink, flow was estimated using the equation $Q=T I W$. In the equation, $T$ is coefficient of transmissibility, in gallons per day per foot; $I$ is hydraulic gradient, in feet per mile; $W$ is length of the underflow strip, in miles; and $Q$ is discharge, in gallons per day. The centripetal flow is assumed to be controlled by the tuff aquitard surrounding the Cenozoic aquifers. A value of 150 gpd per $\mathrm{ft}$, calculated from hydraulic tests, was used for the coefficient of transmissibility of the tuff aquitard, and an average horizontal hydraulic gradient in the tuff aquitard of 25 feet per mile was suggested by data in table 6 . The length of the underflow strip $(W)$, about 15 miles, is the approximate length of the contact separating the welded- and bedded-tuff aquifers from the tuff aquitard on the east, north, and south (pl. 2B); little inflow from the west is likely. The calculated flow toward the sink is about $40 \mathrm{gpm}$, or about 65 acre-feet annually. If water also flows toward the questionable hydraulic sink in the north-central part of the valley, an additional few tens of acre-feet may discharge into the lower carbonate aquifer. However, if, as is likely, the fractures in the tuff aquitard are poorly connected, as noted in the underground workings, then the coefficient of transmissibility (150 gpd per $\mathrm{ft}$ ) derived from the hydraulic tests of wells is much too high, and the actual flow toward the sink may be a fraction of 65 acre-feet annually.

Assuming that leakage from the tuff aquitard to the 
lower carbonate aquifer throughout the valley is vertical, the volume of water in transit can be estimated using the formula $Q=P I A$, where $Q$ is discharge, in gallons per day; $P$ is coefficient of permeability, in gallons per day per square foot; $I$ is vertical component of hydraulic gradient, in feet per foot; and $A$ is cross-sectional flow area, in square feet. The median coefficient of permeability ( $0.00006 \mathrm{gpd}$ per sq $\mathrm{ft}$ ) of the 38 analyses of clayey tuff and clayey sediments listed in table 5 is used for $P$. This value of the coefficient of permeability was used on the assumption that the vertical leakage is controlled principally by the clayey tuff and sediments at the base of the tuff aquitard. A maximum vertical component of hydraulic gradient $(I)$ of 0.2 foot per foot is suggested by the data of table 6 . The area $(A)$ occupied by the tuff aquitard at an altitude of 2,400 feet is about 66 square miles, or about $1,850 \times 10^{6}$ square feet. Using the given values of $P, I$, and $A$, a downward leakage of only about $15 \mathrm{gpm}$, or about 25 acre-feet per year, is calculated. Hydraulic gradients one or more times greater than 0.2 might occur within the basal clayey tuff because its permeability is lower than that of zeolitized tuff, but even gradients several times larger than 0.2 do not increase the leakage to a significant magnitude.

Potentiometric contouring of the water table in Cenozoic aquifers and aquitards in Yucca Flat is unwarranted for two reasons. First, if the movement of water is primarily downward throughout the valley, then contours of such a system are misleading. Second, of the 10 water levels in Cenozoic rock in the eastern two-thirds of the valley ( $\mathrm{pl} .2 \mathrm{C}$ ), three are probably composite levels, and a fourth is a reported level. A single potentiometric contour, hachured to suggest downward movement of water, is shown for the Cenozoic strata on the regional potentiometric map (pl. 1).

The preceding discussion of the ground water within the Cenozoic strata applies only to the eastern twothirds of the valley, where the potentiometric level in all hydrogeologic units ranges from about 2,380 to 2,550 feet. In the vicinity of wells $83-66$ to $83-66 \mathrm{~g}$, water was found in both the tuff aquitard and the underlying clastic aquitard at an altitude about 500 to 1,300 feet higher than the water table in the Cenozoic rocks in the eastern two-thirds of the valley. The high water table in the tuff aquitard reflects the elevated potentiometric level within the upper clastic aquitard; reasons for the higher head within the upper clastic aquitard are discussed under "Interbasin Movement." Similarly, because the potentiometric surface within the lower clastic aquitard is hundreds of feet above that in the lower carbonate aquifer, ground water within the Cenozoic strata beneath the northeastern part of the valley probably also occurs hundreds of feet above that semiperched in the same rocks underlying the eastern two-thirds of the valley. Most of the ground water in these areas should lie within the tuff aquitard, because water in the overlying bedded-tuff, welded-tuff, and valley-fill aquifers probably has drained to lower levels in the central part of the valley.

\section{FRENCHMAN FLAT}

Knowledge of the occurrence and the movement of ground water within Cenozoic strata of Frenchman Flat is based on data from 14 wells or test holes within the valley and 4 wells along the periphery of the drainage basin. The location of these wells, the altitude of the water level in them, and the strata tapped by each are shown in figure 31 . The figure also shows the areal distribution of the hydrogeologic units; subsurface data (Jan. 1967) are insufficient for construction of fence diagrams across the valley or isopach maps and structure-contour maps of the strata underlying this valley,

The regional water table occurs in the major Cenozoic hydrogeologic units at depths ranging from 518 to 1,176 feet beneath the valley floor, but perched water is found at depths as shallow as 70 feet within the tuff and lavaflow aquitards that crop out in the southwestern part of the drainage basin (fig. 31). In general, the depth to the water table is shallowest (about $700 \mathrm{ft}$ ) in wells on the playa and increases to nearly 1,200 feet near the margins of the valley; but exceptions occur in the northwest and the southwest corners of the valley.

The altitudes of the static water levels of the wells show several patterns:

1. Water-table altitudes in the Cenozoic rocks in the eastern two-thirds of the valley (the area east of the Mercury Highway) range from 2,386 to 2,411 feet above mean sea level in nine wells. Of these levels, the three lowest are in wells along the southeastern half of the playa (Frenchman Lake), whereas the water levels in six other wells, as much as 6 miles north of the playa, range from only 2,409 to 2,411 feet above mean sea level (fig. 31).

2. Water levels in the two wells (79-69 and 75-73) tapping the lower carbonate aquifer along the north and the east peripheries of the valley are 10 to 30 feet lower than the levels in the Cenozoic hydrogeologic units; the water level in well 73-66, which taps the lower carbonate aquifer along the southwestern edge of the basin, is also lower than all but two of the wells tapping the Cenozoic rocks. Thus, ground water in the Cenozoic rocks is semiperched with respect to that in the lower carbonate aquifer.

3. Water-level altitude in two wells west of the Mercury Highway (fig. 31) - wells 77-68 in the northwestern part of the valley (the CP Basin) and well 73-68 in 


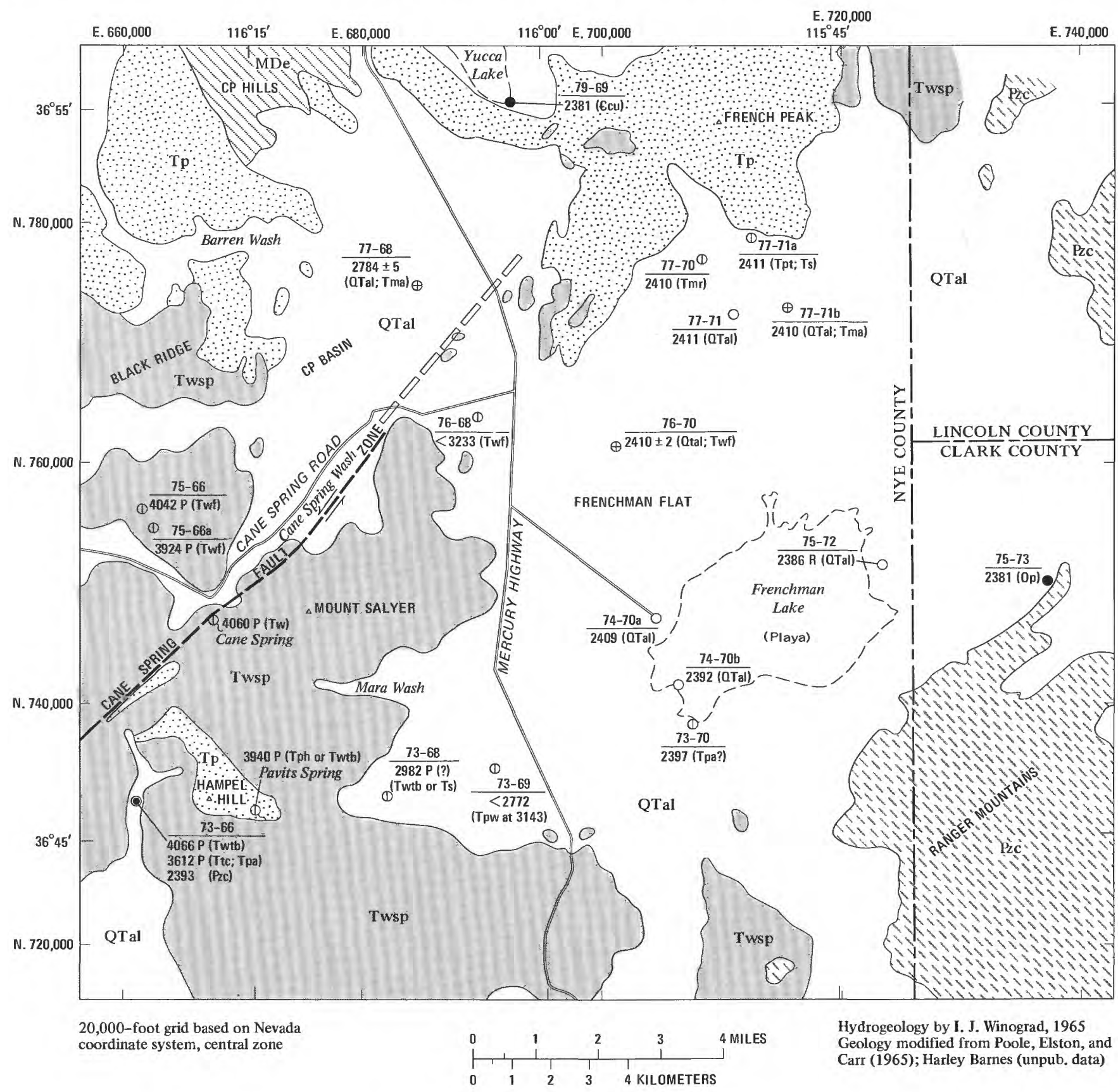

Figure 31. - Hydrogeology of Frenchman Flat.

the southwest corner - are nearly 400 and 600 feet higher, respectively, than the water levels in wells east of the highway.

The anomalously high water level in well 73-68 probably represents a perched zone of saturation within the tuff aquitard. This well penetrated the tuff aquitard at a depth of 165 feet and bottomed in the aquitard at a depth of 1,504 feet. Drillers first reported water at a depth of about 660 feet. Several days after completion of drilling, the water level stood 518 feet below land surface (water-level alt 2,982 $\pm 2 \mathrm{ft}$ ). Perched water at three other nearby places within the tuff aquitard - Pavits Spring, Cane Spring, and well 73-66 (fig. 31) - indicates that the water level in well $73-68$ is probably perched or possibly semiperched. The altitudes of the perched water at Cane Spring, Pavits Spring, and well 73-66 are $4,060,3,940$, and 4,066 feet, respectively, or roughly 1,000 to 1,100 feet higher than the level in the well 73-68; but the aquitard, which crops out at these three sites, is as much as 600 to 700 feet higher than the top of the aquitard (alt 3,335 ft) beneath the site of well 73-68.

The hills and the flanking valley floor in the 


\section{EXPLANATION}

\begin{tabular}{|c|c|c|}
\hline \\
\hline & QTal & \\
\hline \multicolumn{3}{|c|}{$\begin{array}{l}\text { Valley-fill aquifer } \\
\text { Alluvial fan, fluvial, fanglomerate, lakebed, and mudflow deposits }\end{array}$} \\
\hline \multicolumn{3}{|c|}{$\because \mathbf{T} \mathbf{p}$} \\
\hline \multicolumn{3}{|c|}{$\begin{array}{l}\text { Welded-tuff and bedded-tuff aquifers } \\
\text { mi-welded tuff of Piapi Canyon Group; interbedded vitric ash-fall } \\
\text { tuff is bedded-tuff aquifer }\end{array}$} \\
\hline \multicolumn{3}{|c|}{ rowe } \\
\hline \multicolumn{3}{|c|}{$\begin{array}{l}\text { Tuff and lava-flow aquitards } \\
\text { Ash-fall and ash-flow tuff massively altered to zeolite or clay; lava flows; also in- } \\
\text { clude tuffaceous and clayey lake deposits; predominantly rocks of Wahmonie, } \\
\text { Salyer, and Horse Spring Formations and Rocks of Pavits Spring }\end{array}$} \\
\hline \multicolumn{3}{|c|}{ स्क्त्र } \\
\hline \multicolumn{3}{|c|}{$\begin{array}{l}\text { Upper clastic aquitard } \\
\text { Argillite, quartzite, conglomerate, and minor limestone of Eleana Formation; } \\
\text { overlain at shallow depth by upper carbonate aquifer and by klippen of lower } \\
\text { carbonate aquifer and lower clastic aquitard }\end{array}$} \\
\hline \multicolumn{3}{|c|}{ Siscing } \\
\hline \multicolumn{3}{|c|}{$\begin{array}{l}\text { Lower carbonate aquifer } \\
\text { Dolomite and limestone; minor shale and quartzite }\end{array}$} \\
\hline \multicolumn{3}{|c|}{ Contact } \\
\hline & - - & \\
\hline \multicolumn{3}{|c|}{$\begin{array}{c}\text { Fault } \\
\text { Arrows indicate direction of relative movement; dashed where approximately } \\
\text { located }\end{array}$} \\
\hline \multicolumn{3}{|c|}{ HYDROGEOLOGIC AND GEOLOGIC UNITS } \\
\hline SYMBOL & GEOLOGIC UNIT & HYDROGEOLOGIC UNIT \\
\hline QTal & Valley fill & Valley-fill aquifer \\
\hline Tma & $\begin{array}{l}\text { Ammonia Tanks Member of Timber } \\
\text { Mountain Tuff }\end{array}$ & \\
\hline Tmr & $\begin{array}{l}\text { Rainier Mesa Member of Timber } \\
\text { Mountain Tuff }\end{array}$ & \\
\hline Tpt & $\begin{array}{l}\text { Topopah Spring Member of Paint- } \\
\text { brush Tuff }\end{array}$ & \\
\hline Tph & $\begin{array}{l}\text { Sandstone and tuff of Hampel Hill } \\
\text { (lower part of Piapi Canyon } \\
\text { Group) }\end{array}$ & \\
\hline Tpw & $\begin{array}{l}\text { Tuff and sandstone of Piapi Canyon } \\
\text { Group, and tuff, sandstone, and } \\
\text { lithic tuff of Wahmonie Forma- } \\
\text { tion undifferentiated }\end{array}$ & $\begin{array}{l}\text { Tuff aquifers and aquitard } \\
\text { and lava-flow aquitard }\end{array}$ \\
\hline Tw & $\begin{array}{l}\text { Wahmonie Formation undifferen- } \\
\text { tiated }\end{array}$ & \\
\hline Twf & $\begin{array}{l}\text { Dacite and rhyodacite lava flows } \\
\text { of Wahmonie Formation }\end{array}$ & \\
\hline Twtb & $\begin{array}{l}\text { Tuff, sandstone, and lithic tuff } \\
\text { breccia of Wahmonie Forma- } \\
\text { tion }\end{array}$ & \\
\hline Ts & Salyer Formation undifferentiated & \\
\hline Ttc & Tuff of Crater Flat & \\
\hline Tpa & Rocks of Pavits Spring & \\
\hline $\begin{array}{l}\text { Prc } \\
\text { Op } \\
\text { Ecu }\end{array}$ & $\begin{array}{l}\text { Paleozoic carbonate rock } \\
\text { Pogonip Group } \\
\text { Carrara Formation, upper half }\end{array}$ & Lower carbonate aquifer \\
\hline
\end{tabular}

\section{HYDRAULIC SYMBOLS}

NOTE: All altitudes in feet; datum is mean sea level; potentiometric contours not drawn for reasons outlined in text

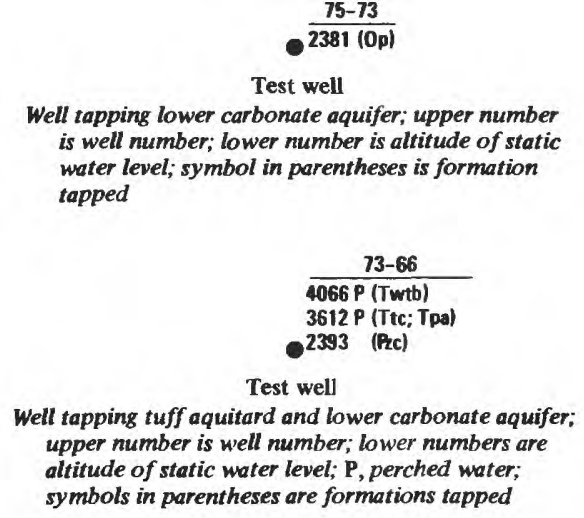
is well number; lower number is altitude of static water level; symbol in parentheses is formation tapped

Well tapping tuff aquitard and lower carbonate aquifer; upper number is well number; lower numbers are altitude of static water level; $\mathbf{P}$, perched water; symbols in parentheses are formations tapped

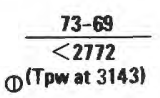

Test well

Well tapping Tertiary hydrogeologic units; upper number is well number; lower number is altitude of static water level; symbol and number in parentheses are formation tapped and its altitude; symbol < denotes well was dry

$$
\mathrm{O}^{\frac{75-72}{2386 \text { R (0Tal) }}}
$$

Test well or water well

Well tapping valley-fill aquifer; upper number is well number; lower number is altitude of static water level; $\mathrm{R}$, reported water level; symbol in parentheses is formation tapped

$$
\oplus \frac{77-71 b}{2410 \text { (0Tal; Tma) }}
$$

Test well

Well tapping both valley-fill aquifer and Tertiary hydrogeologic units; upper number is well number; lower number is altitude of static water level; symbols in parentheses are formations tapped

$$
\rho^{4060 P(T w)}
$$$$
\text { Spring }
$$

Number is altitude; $\mathrm{P}$, perched or semiperched; symbol in parentheses is formation supplying spring

Dry lakebed

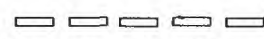

Inferred ground-water barrier

Width of symbol not intended to represent width of barrier, which may range from several tens to a few thousand feet

FIGURE 31.-Continued. 
southwestern part of Frenchman Flat (fig 31), probably contain perched or possibly semiperched ground water at altitudes hundreds of feet above the water table beneath the eastern two-thirds of the valley. The existence of such a perched ground-water mound is likely because of the extremely low gross transmissibility of the aquitards and their structurally high position near the flanks of the valley.

The anomalously high water level in well 77-68 in the northwestern part of Frenchman Flat, an area called the CP Basin (fig. 31), is due, at least in part, to low gross transmissibility of the lava-flow aquitard. Well 77-68 penetrated 1,093 feet of the valley-fill aquifer and 150 feet of the welded-tuff aquifer. The water level in well 77-68 stands at a depth of $796 \pm 5$ feet, or at an alittude of 2,784 feet above mean sea level; this level is approximately 370 feet higher than water levels in either the valley-fill or the welded-tuff aquifers east of the Mercury Highway (fig. 31). Because of the moderate to high transmissibility of the valley-fill and the welded-tuff aquifers (table 3 ) and because of the very low hydraulic gradient within these aquifers east of the Mercury Highway, the anomalously high water level in well 77-68 cannot be ascribed to perching or semiperching of water within strata of low gross transmissibility or to the existence of steep hydraulic gradients within the aquifers. A hydraulic discontinuity must exist between the valleyfill and the welded-tuff aquifers beneath the CP Basin and the same aquifers beneath the eastern two-thirds of the valley, as shown in figure 31 .

The Cane Spring fault zone may extend northeastward and form this barrier, either by offsetting permeable units or by forming a curtain of fault gouge. The outcrop pattern and the data from test hole 76-68 suggest that the lava-flow aquitard occurs at relatively shallow depth beneath the arm of the valley connecting the CP Basin to the remainder of the valley. This interpretation is supported by a gravity map of the area (D. L. Healey, oral commun., 1965), which shows a northeast-trending gravity high connecting the unnamed hills northeast and southwest of the highway.

In marked contrast to the two anomalous water levels in the northwest and the southwest corners of the valley, the water levels in nine wells tapping the valley-fill and the welded-tuff aquifers east of the Mercury Highway differ by only 25 feet; moreover, water levels in six of these wells differ by only 2 feet.

The static water levels in five test holes in the northern half of the valley probably represent the top of the zone of saturation. The static levels in test holes 77-70, 77-71, and 77-71a were measured only after completion of the drilling; hence, any head changes with increasing depth would be reflected in the levels obtained. The water level in well $77-71 \mathrm{~b}$ was measured after penetration of about 720 feet of saturated valley fill, yet its water-level altitude is the same as that measured in the three nearby wells that penetrated only 112 to 272 feet of the valleyfill or the welded-tuff aquifer. The similarity of waterlevel altitude in these wells suggests either little downward movement in the Cenozoic aquifers in this part of the valley or very small head losses accompanying vertical flow through the aquifers. The static water level in well 76-70 (alt 2,410 $\pm 2 \mathrm{ft}$ ) was measured during a shutdown period before completion of drilling but after penetration of about 452 feet of valley-fill aquifer. This level is also considered representative of the head at the top of the zone of saturation because of its similarity to the other water-level altitudes within the valley-fill aquifer. However, after this well had been cased to 1,682 feet and drilled to 2,682 feet, about 1,330 feet into the lava-flow aquitard, the static water level had dropped to an alittude of 2,392 feet, or 18 feet lower than the level in the valley-fill aquifer. This drop in head is further evidence that water in the Cenozoic strata in Frenchman Flat is semiperched compared with that in the lower carbonate aquifer, which underlies most of the valley.

The key question on the measured water levels in the three water-supply wells $(73-70,74-70 \mathrm{~b}$, and 74-70a) concerns the amount of dewatering since pumping began in the early 1950 's. Hood (1961, p. 48-52) concluded that the dewatering as a result of pumping from 1951 through 1960 could have been as much as 2 feet in well 73-70 and as much as 6 feet in well 74-70a. A reevaluation of Hood's conclusions using more recent water-level data suggests that dewatering in wells $74-70 \mathrm{~b}$ and 74-70a (as of 1961) was less than 4 feet. The water-level altitudes for these wells (fig. 31 ) represent levels measured after well 74-70a had been shut down for 6 days in 1959 and after a 133-day shut-down of well $74-70 \mathrm{~b}$ in 1960-61. These water levels are probably within 4 feet of the static water level under virgin conditions.

There is no detectable horizontal component of hydraulic gradient among the test wells in the north half of the valley or between these wells and water-supply well 74-70a in the south half. If a hydraulic gradient exists, it is a fraction of a foot per mile. In contrast, hydraulic gradients of up to 16 feet per mile seemingly exist between the three wells along the west edge of the playa. Reasons for the contrast between hydraulic gradients in the north and south halves of the valley are not clear, but the contrast appears real. Water levels in the three watersupply wells and destroyed well 75-72 suggest that a hydraulic sink may exist in the vicinity of well 74-70b, and possibly near well 75-72. But the existence of a sink in the valley-fill aquifer tapped by these two wells seems incompatible with the apparent absence of a gradient in this aquifer northwest of the playa.

Available subsurface geologic data are insufficient to explain the water-level patterns. By analogy with con- 
ditions in Yucca Flat, the water levels in Frenchman Flat may be interpreted as follows: the lower water levels in wells 74-70b and 75-72 represent a hydraulic sink formed by geologic conditions favoring a direct hydraulic connection between the valley-fill aquifer and the underlying lower carbonate aquifer. The apparent absence of a hydraulic gradient in the valley-fill aquifer in the northern half of the valley in turn suggests that a northeast-trending hydraulic barrier that retards water flow exists near the northwest end of the playa (Frenchman Lake). The suggested barrier parallels the trend of the major faults cutting both the Cenozoic and the Paleozoic strata, including the Cane Springs fault zone mentioned above as a possible barrier isolating the CP Basin.

The low water-level altitudes in two of the three wells (75-72 and 73-70) in the southeastern half of the playa may reflect a relatively shallow depth to Paleozoic rocks beneath the bottom of these wells. A gravity map suggests that Paleozoic rocks may be only about 700 feet beneath the bottom of well 75-72 and about 1,200 feet beneath well 73-70. Proximity of the bottom of the two wells (75-72 and 73-70) to the underlying carbonate aquifer might facilitate downward drainage of the Cenozoic strata if the tuff aquitard was fre tured. However, the low potentiometric level in production well 74-70b cannot readily be attributed to the proximity of the pre-Tertiary rocks, which the gravity map indicates are roughly 2,400 feet beneath the bottom of this well.

The very low gradient in the valley fill in the northern half of the valley may reflect extremely high transmissibility, the lateral movement of very small quantities of water through the aquifer, or a combination of high transmissibility and small volume of water in transit. The hydraulic tests of the valley-fill aquifers at Nevada Test Site indicate that those aquifers have only low to moderate transmissibility (table 3 ). Thus, the low gradient must reflect the lateral movement of small quantities of water. An alternative interpretation is that there is little or no lateral movement within the valleyfill or the welded-tuff aquifer in northern Frenchman Flat; that is, the water is ponded above the lower carbonate aquifer by the surrounding and the underlying older aquitards and by the postulated hydraulic barrier.

Ground water semiperched in the Cenozoic aquifers in Frenchman Flat probably cannot leave the valley without entering either the tuff or the lava-flow aquitard or the lower carbonate aquifer. Geologic maps and a gravity map of the Frenchman Flat area indicate that the valley fill is enclosed on all sides by older rocks and that the welded-tuff aquifer is probably surrounded and underlain by either the lava-flow aquitard or the tuff aquitard. That is, neither the valley-fill nor the weldedtuff aquifer occurs beneath the 2,400-foot level along the periphery of the valley. Therefore, if ground water in the
Cenozoic aquifers is to leave the valley, it can do so either by lateral flow toward an adjacent valley through the surrounding and underlying Tertiary aquitards or by downward movement through the tuff aquitard into the underlying lower carbonate aquifer. It could also move laterally through the aquitard - for example, toward the Ranger Mountains - and then enter the lower carbonate aquifer.

That ground water in the Cenozoic aquifers leaves the valley by entering the lower carbonate aquifer rather than by lateral movement into another valley via the surrounding aquitards is suggested by the following:

1. Water-level altitudes in the Cenozoic strata in Yucca Flat and Jackass Flats are virtually the same as those in Frenchman Flat. This condition is inconsistent with lateral movement of significant quantities of water through the aquitards because such movement would require locally steep hydraulic gradients and in turn would result in markedly different altitudes of the water tables in these valleys.

2. The small (9-ft) range between the lowest water levels (in Cenozoic rocks) in Yucca Flat, Frenchman Flat, and Jackass Flats (pl. 1) suggests a common base level to which the semiperched ground water in these valleys drains, the head within the widespread and highly transmissive lower carbonate aquifer.

3. The scant well data for the valley can be interpreted to suggest internal drainage into the underlying lower carbonate aquifer beneath the playa.

4. A structure-contour map of the Frenchman Flat area suggests that the lower carbonate aquifer rises above the 2,400-foot level on all sides of the valley except possibly the southwestern side (C. H. Miller and D. L. Healey, written commun., Feb. 1965). Thus, even if ground-water movement through the aquitard is lateral or if the aquitard is missing, water would still enter the lower carbonate aquifer within the drainage area of the valley.

The authors believe that the semiperched ground water in the Cenozoic aquifers and aquitards leaves the valley by downward leakage into the underlying carbonate aquifers. The water can move through structurally controlled sinks as may exist beneath Frenchman Lake, through vertical drainage throughout the valley, or through both mechanisms operative in different parts of the valley. By analogy with Yucca Flat, the magnitude of such leakage should be no greater than 70 acre-feet annually.

Available data do not justify construction of potentiometric contours for the Cenozoic aquifers in the valley. A single hachured contour, labeled 2,400 feet and inserted on the small-scale regional potentiometric map (pl. 1), indicates that drainage of ground water within Frenchman Flat is probably internal. 
Because the water table in Frenchman Flat is considerably shallower than that beneath Yucca Flat, the saturated extent of the valley-fill aquifer in Frenchman Flat is considerably greater than that in Yucca Flat. The valley fill is saturated beneath an area at least 6 miles long and at least $41 / 2$ miles wide and thus has a minimum saturated area of about 27 square miles. In contrast, the valley fill in Yucca Flat is saturated beneath an area of less than 10 square miles. The saturated thickness of the valley fill in Frenchman Flat is probably at least 500 feet within the polygon formed by lines connecting wells 74-70b, 74-70a, 76-70, 77-71, 77-71b, and 75-72. Thus the valley-fill aquifer is of major importance in this valley. The welded-tuff aquifer is probably of secondary importance in Frenchman Flat: first, because it is buried more deeply than valley fill, and second, because it is absent or very thin beneath the southern half of the valley.

\section{OTHER VALLEYS}

By analogy with Yucca and Frenchman Flats, leakage of semiperched water is also probable beneath northern Indian Springs Valley and northern Three Lakes Valley (north of U.S. Highway 95), eastern Emigrant Valley, and Desert Valley (fig. 1). The basis for the analogy is: (1) The water table in the Cenozoic rocks beneath these valleys is relatively deep (it generally ranges from 300 to $700 \mathrm{ft}$ ); (2) the basal Tertiary rocks (Horse Spring Formation or equivalent) are aquitards; (3) the Tertiary rocks are underlain principally by the lower carbonate aquifer; and (4) all these valleys, except Desert Valley, are remote from major recharge areas; thus, the probability of higher heads in the lower carbonate aquifer than in the Cenozoic strata is unlikely.

In southern Indian Springs Valley, southern Three Lakes Valley (south of U.S. Highway 95), east-central Amargosa Desert, and possibly also eastern Jackass Flats (fig. 1), the Cenozoic aquifers are recharged principally by upward leakage from the lower carbonate aquifer. This upward movement is related in part to prominent hydraulic discontinuities within the lower carbonate aquifer.

\section{INTERBASIN MOVEMENT}

Regional movement of ground water through the lower carbonate aquifer flanking and underlying the valleys at Nevada Test Site and vicinity is called interbasin movement in this report. Such movement of ground water is not significantly influenced by the topographic boundaries of the individual valleys. One of the major controls of such movement is rather the disposition of the lower carbonate aquifer and of the lower and upper clastic aquitards (table 1). The lateral movement of ground water through the carbonate aquifer integrates several intermontane valleys into a single large groundwater basin, the Ash Meadows ground-water basin.

\section{EVIDENCE FOR INTERBASIN MOVEMENT}

Water-level altitudes in wells tapping the lower carbonate aquifer in Yucca and Frenchman Flats, in Mercury Valley, and in east-central Amargosa Desert offer the most direct evidence of interbasin movement within the lower carbonate aquifer (pl. 1). Water levels indicate a hydraulic gradient from northwestern Yucca Flat and from eastern Frenchman Flat toward the Ash Meadows discharge area; the gradient generally ranges from 0.3 to 5.9 feet per mile to the south and the southwest. The water-level altitudes between well 88-66 in northern Yucca Flat and Devils Hole, a cavern in the discharge area, differ by only 56 feet; these control points are 58 miles apart. In the 53 miles between well 85-68 in northcentral Yucca Flat and Devils Hole, the difference in water-level altitude is only about 28 feet; the apparent hydraulic gradient is only 0.5 foot per mile. In this distance, the land-surface altitude of the valley floors drops about 2,000 feet. Depth to the static water level in the lower carbonate aquifer decreases from about 2,055 feet below land surface to at least several feet above land surface. Plate 1 illustrates these relations.

The cited hydraulic gradients may be step-like rather than smooth, as fault zones may locally compartmentalize the lower carbonate aquifer. Whether or not compartmentalization (discussed later in this report) exists does not change the fact of decreasing potential energy in a south and southwesterly direction from Yucca Flat toward the Amargosa Desert.

Additional evidence for interbasin movement of ground water is based on (1) the wide subsurface distribution of the lower carbonate aquifer, (2) the similarity in water-level altitudes in the Cenozoic strata in several valleys, (3) the chemistry of the ground water, and (4) the anomalous relationship of the spring discharge at Ash Meadows to the size of the apparent catchment area for this discharge. These are discussed briefly in the following paragraphs.

1. The lower carbonate aquifer occurs within the upper several thousand feet of the zone of saturation throughout most of the study area. It underlies both the ridges and the saturated Cenozoic aquifers and aquitards beneath the valley floors. The saturated thickness of the lower carbonate aquifer generally ranges from only a few tens of feet in the vicinity of the areas where the lower clastic aquitard is close to the surface (pl. 1) to possibly as much as 10,000 feet beneath central Yucca Flat; projections of mapped areal geology suggest that saturated thickness of the lower carbonate aquifer is probably at least 4,000 feet thick beneath most of the study area. Because of the widespread distribution of the lower carbonate aquifer, interbasin movement of ground water through this aquifer is both possible and probable. 
2. The water-level altitudes in the Cenozoic aquifers and aquitards in Yucca Flat, Frenchman Flat, Jackass Flats, and northern Indian Springs Valley (north of U.S Highway 95) differ by less than 170 feet; and the lowest water levels in the three flats differ by only 9 feet. By contrast, the water table in Emigrant Valley, Kawich Valley, Gold Flat, southern Indian Springs Valley (south of U.S. Highway 95), and northern Three Lakes Valley (north of U.S. Highway 95) range from 370 to 2,600 feet higher than the lowest water levels in the three flats. The similarity in water-level altitudes in the three flats and in northern Indian Springs Valley suggests that these valleys are graded to a common discharge area.

3. The chemical quality of water from the lower carbonate aquifer beneath Yucca and Frenchman Flats closely resembles that of water emerging from springs in the major discharge area at Ash Meadows. In contrast, the chemical quality of ground water from the lower carbonate aquifer in other areas and of ground water in the Cenozoic aquifers of Yucca and Frenchman Flats differs markedly from that of the water emerging in the discharge area. (See discussion under "Ground Water Chemistry, Hydrochemical Facies, and Regional Movement of Ground Water.")

4. The marked anomaly between the large measured spring discharge at Ash Meadows (about 10,600 gpm, or 17,100 acre-ft per yr) and the small size (a few hundred square miles) and aridity of the precipitation catchment area for this discharge is suggestive of interbasin movement. This basic hypothesis was first discussed by Omar Loeltz, U.S. Geological Survey (1960).

The evidence for interbasin movement of ground water through the lower carbonate aquifer at Nevada Test Site and vicinity is strong. Since completion of test drilling at Nevada Test Site, other hydrologists using the preceding and other criteria have postulated that interbasin movement of ground water occurs in other parts of the miogeosyncline in the eastern one-third of Nevada. Eakin $(1965,1966)$ stated, for example, that 13 intermontane valleys within or adjacent to the White River drainage basin in east-central Nevada are hydraulically integrated into a single ground-water basin by movement of water through the Paleozoic carbonate rocks. Maxey and Mifflin (1966) inferred that interbasin movement of ground water best explains the uniform yield of most of the highyield springs in the miogeosyncline. Malmberg (1967) stated that approximately 12,000 acrefeet annually leaves Pahrump Valley by subsurface outflow through the Paleozoic carbonate aquifers toward California.
INFLUENCE OF CLASTIC AQUITARDS AND MAJOR SHEAR ZONES ON INTERBASIN MOVEMENT

Interbasin movement of ground water within the lower carbonate aquifer is greatly influenced by major geologic structures, particularly by folds that bring the lower clastic aquitard close to the surface or by faults that juxtapose the lower or the upper clastic aquitards and the lower carbonate aquifer. In some areas, such geologic structures result in water levels differing as much as 2,000 feet between adjacent valleys or as much as 500 feet in carbonate aquifers within a single valley. In other areas, where the clastic aquitards are absent, some major faults within the carbonate rocks may also act as hydraulic barriers, or ground-water dams, and may compartmentalize (but not necessarily totally isolate) the carbonate aquifer. In still other areas, hydraulic barriers may be totally absent; or more likely, they may not be discernible because of the low hydraulic gradients. Areas illustrating the effect of geologic structure on water movement in the lower carbonate aquifer are discussed in the following sections of the report.

\section{NORTHEASTERN YUCCA FLAT-WESTERN EMIGRANT VALLEY}

The alluvial apron west of Groom Lake playa in Emigrant Valley (fig. 32) is bordered on the east, south, and southwest by the lower clastic aquitard. Except along the west edge of Groom Lake playa, the lower clastic aquitard is exposed continuously on the east in the Groom and Papoose Ranges for a distance of about 25 miles; the strata dip eastward. On the south and southwest the lower clastic aquitard is discontinuously exposed over a distance of 10 miles in the Halfpint Range. Data from well 89-68 and geologic mapping indicate that the lower clastic aquitard extends at least another 2 miles northwest of the northernmost outcrop in the Halfpint Range and that the northwestwardtrending clastic rocks are truncated by the Climax stock (fence diagram of Yucca Flat, pl. 2A). A gravity survey indicates that the pre-Tertiary rocks are now buried as much as 4,000 feet beneath the floor of western Emigrant Valley (D. L. Healy and C. H. Miller, written commun., 1965).

The geologic and hydraulic section extending from northeastern Yucca Flat to Groom Lake playa (fig. 32) is approximately at right angles to the major structural trends. Water levels in three widely spaced wells tapping the valley-fill aquifer in western Emigrant Valley range from 4,340 to 4,371 feet above mean sea level and indicate a gentle hydraulic gradient sloping eastward toward the playa at about 4 feet per mile. Water levels in wells tapping older rocks immediately east and west of western Emigrant Valley are considerably lower than levels in wells tapping the valley-fill aquifier. The high 


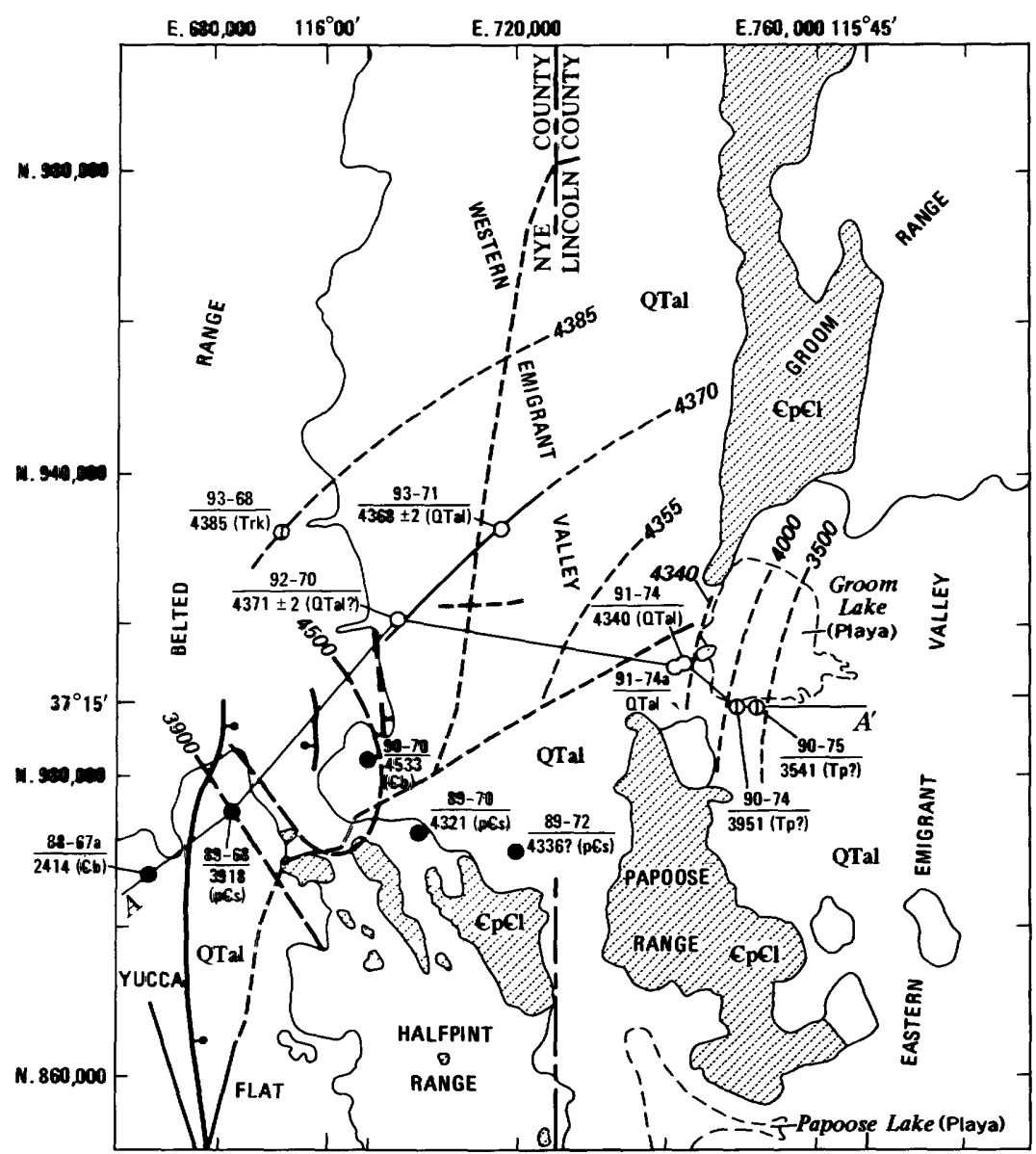

Base from U.S. Geological Survey 1:250,000 Modified from Winograd and Thordarson Caliente and Goldfield, 1954 (1968, fig. 2). Geology compiled from unpub20,000-foot grid based on Nevada lished maps by Harley Barnes, E. N. Hinrichs, coordinate system, central zone P. P. Orkild, and F. A. McKeown, and Tschanz and Pampeyan (1961)
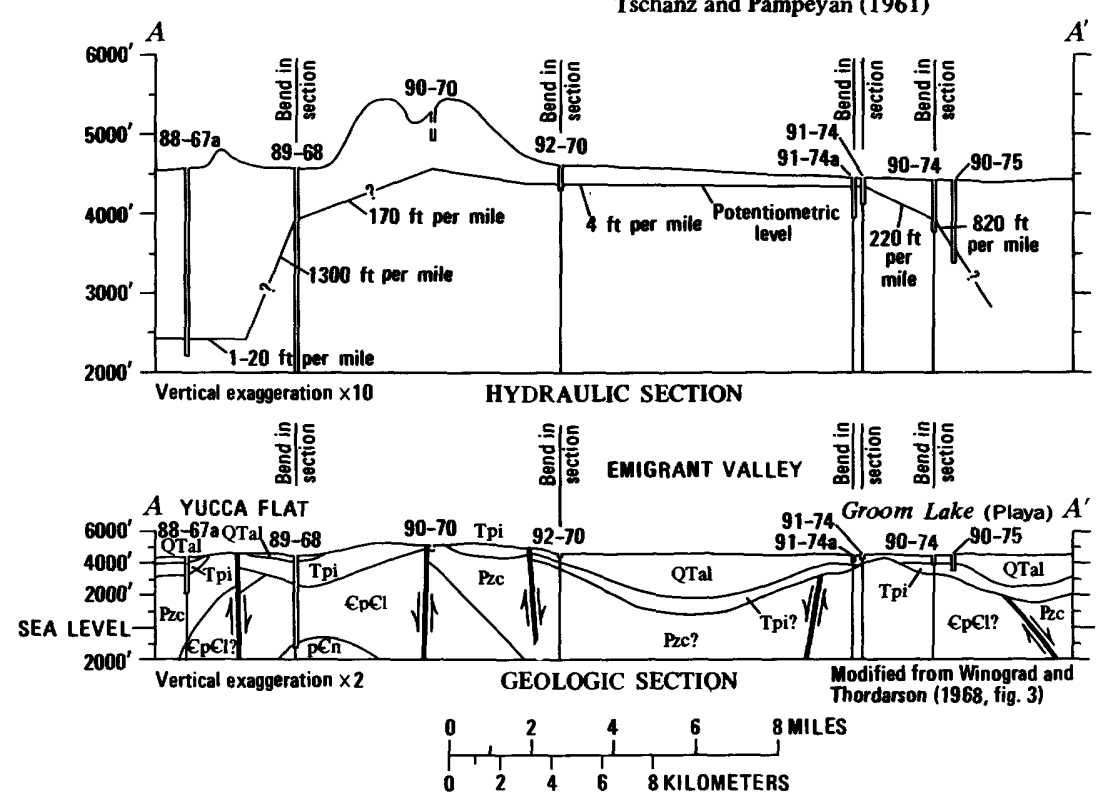

FIGURE 32. - Hydrogeology of Emigrant Valley. 


\section{EXPLANATION}

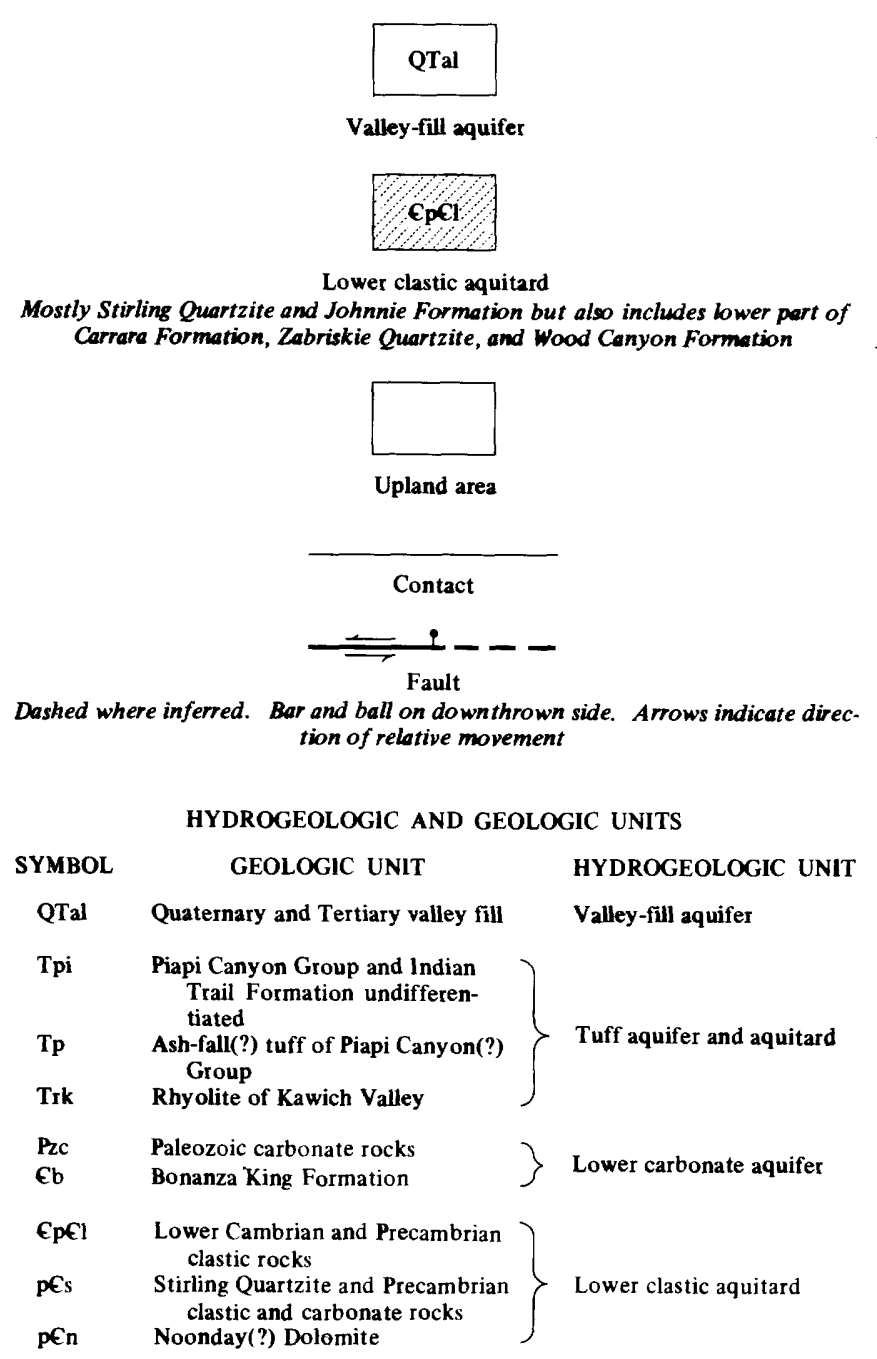

HYDRAULIC SYMBOLS

Note: All altitudes and contours in feet:datum is mean sea level

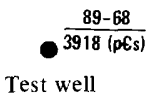

Well tapping pre-Tertiary hydrogeologic units: upper number is well number; lower number is altitude of static water level: symbol in parentheses is formation tapped

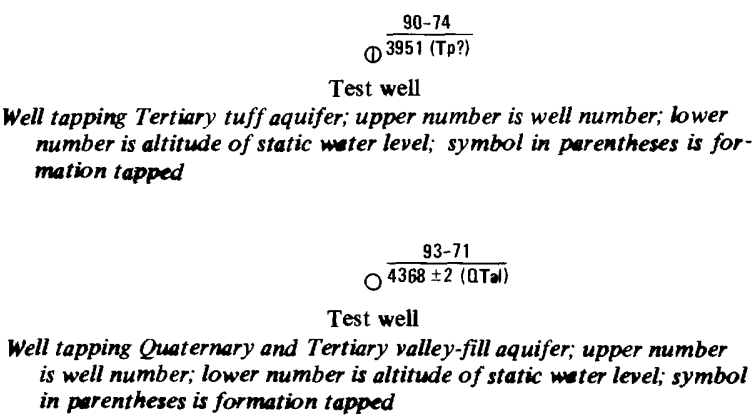
number is altitude of static water level; symbol in parentheses is formation tapped

$$
\frac{93-71}{4368 \pm 2(0 T 2)}
$$

Test well

Well tapping Quaternary and Tertiary valley-fill aquifer; upper number is well number; lower number is altitude of static water level; symbol in parentheses is formation tapped

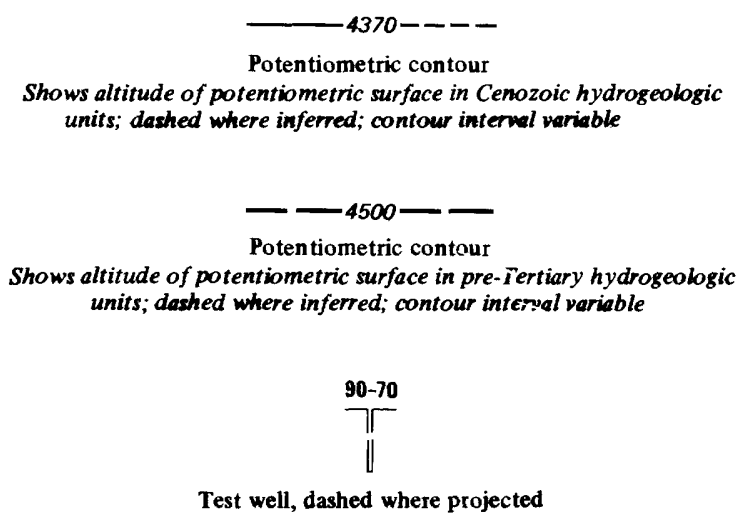

FIGURE 32. - Continued. and virtually flat potentiometric surface in the valley-fill aquifer within western Emigrant Valley and the steep hydraulic gradients developed in the older rocks in the flanking areas probably are caused by a higher outlet for discharge from the valley-fill aquifer than for the older rocks and by a lower gross transmissibility of and a lower hydraulic outlet for the clastic rocks that surround and underlie western Emigrant Valley. The steep hydraulic gradients on both ends of the cross section probably reflect the movement of water through the thick lower clastic aquitard or tuff aquitard toward points of lower head in Yucca Flat and in eastern Emigrant Valley.

The high water level within the valley-fill reservoir probably is due to impoundment by the impermeable clastic rocks. Along the west edge of Groom Lake playa, about 1,000 feet northeast of well 91-74, an outlier of Precambrian quartzite (Stirling Quartzite) rises a few feet above the playa surface (fig. 32). This outlier and a gravity survey indicate that the Precambrian and Lower Cambrian clastic rocks composing the Groom and Papoose Ranges form a continuous buried ridge at very shallow depth along the west side of the playa and under well 91-74. The gravity survey also indicates that the depth to bedrock increases steeply in both directions from this buried ridge (D. L. Healey and C. H. Miller, written commun., 1965). The buried ridge is probably acting as the spillway for the valley-fill reservoir, which is saturated to within 100 feet of the surface. That the clastic rocks act as a hydraulic barrier or dam was first hypothesized in 1957 by Omar Loeltz (written commun., 1959).

The saturation of the valley fill to within 107 feet of the land surface at well 91-74 in Emigrant Valley and the slope of the potentiometric surface in that aquifer toward the playa (where the clastic aquitard is largely buried) suggest that very little water leaves the valley by 
movement through the clastic aquitard. The lower clastic aquitard thus acts as an effective hydraulic discontinuity between the lower carbonate aquifer downfaulted beneath western Emigrant Valley (fig. 32) and the same aquifer beneath northeastern Yucca Flat and beneath eastern Emigrant Valley (east of the Groom and Papoose Ranges).

Two qualifications of the preceding arguments are necessary. First, an objection may be raised that water levels in the Tertiary and Quaternary aquifers should not be utilized as a reflection of heads within the lower clastic aquitard. However, in Yucca and Frenchman Flats, Indian Springs Valley, and Amargosa Desert, water levels in the Cenozoic aquifers and aquitards beneath the valley floors are usually within 100 feet of levels in the underlying Paleozoic aquifers and aquitards, except where true perched conditions exist along the margins of the valleys. This fact, coupled with the large differences in water levels between wells along the east and west ends of the western Emigrant Valley area, makes the use of water levels in Cenozoic rocks as indicators of heads in the clastic aquitard appear valid. Moreover, in both Emigrant Valley and the other areas to be discussed, at least one control point in the preTertiary rocks is available.

The second qualification is that the hydraulic gradients within the lower clastic aquitard may not be continuous; the water levels may instead reflect discontinuous levels within blocks of aquitard separated by faults. Whether the gradients are continuous or steplike does not materially change the principal interpretation, namely that the lower clastic aquitard is an effective hydraulic barrier.

\section{NORTHWESTERN AND WEST-CENTRAL YUCCA FLAT}

Water levels in wells of northwestern and west-central Yucca Flat (pl. $2 C$ ) offer another example of the compartmentalization of the lower carbonate aquifer, but in this case by the upper clastic aquitard. Northwestern and west-central Yucca Flat is bordered on the west by the upper clastic aquitard (Eleana Formation), which forms Quartzite Mountain, the Eleana Range, and several smaller unnamed ridges. These ridges extend nearly 18 miles in a north-northeasterly direction and form a nearly unbroken trend of the upper clastic aquitard. The aquitard, which ranges from 4,000 to 8,000 feet in thickness, also underlies the western one-third of the valley floor. The approximate eastern limit of the upper clastic aquitard at the 2,400-foot level is shown by plate $2 B$ and $C$.

The difference of water-level altitude within the lower carbonate aquifer east and west of the area underlain chiefly by the upper clastic aquitard is about 1,800 feet. The water-level altitude within the lower carbonate aquifer in central Yucca Flat ranges from 2,381 feet at well 79-69a at the south end of the valley to 2,415 feet in well 88-66 at the northwest end. About 7 miles west of well 88-66, well 87-62 (south of Rainier Mesa) also taps the lower carbonate aquifer (pl. $2 C$ ); but here the potentiometric surface of the aquifer is 4,189 feet above mean sea level. The lower carbonate aquifer at this site has been thrust over the upper clastic aquitard, as shown in fence $\mathrm{C}-1$ to $\mathrm{C}-2$ of plate $2 A$ and in the section on plate 1. The difference in water-level altitude is attributed directly to the low gross transmissibility of the intervening aquitard. The apparent hydraulic gradient within the aquitard between the two wells is about 330 feet per mile (pl. 1).

Data from several wells in the upper clastic aquitard and one in the upper carbonate aquifer in west-central Yucca Flat suggest that an apparent hydraulic gradient as steep or steeper than the one cited also exists within the upper clastic aquitard south of the wells cited in the preceding paragraph. The gross stratigraphy and the potentiometric surface at these well sites is given in the cross section of plate $2 C$. The section also illustrates another example of compartmentalization of the carbonate aquifers by the upper clastic aquitard. Well 83-66c bottomed within the basal part of the upper carbonate aquifer, the Tippipah Limestone. The potentiometric level within the limestone is, however, 500 feet higher than levels within the lower carbonate aquifer or the Cenozoic rocks about $21 / 2$ miles east of the well. The marked difference in potentiometric level is again attributed to the upper clastic aquitard being between the two carbonate aquifers.

Beneath central and northern Yucca Flat, the lower and the upper clastic aquitards (pl. $2 B$ and $C$ ) isolate the lower carbonate aquifer from adjacent valleys. Thus, any interbasin movement of ground water into the lower carbonate aquifer would have to pass through and be controlled by the transmissibility of the clastic aquitards. However, an important distinction exists between the upper clastic aquitard bordering the valley on the west and the lower clastic aquitard bordering it on the northeast. In western Yucca Flat the upper clastic aquitard probably is underlain by thousands of feet of lower carbonate aquifer, whereas the lower clastic aquitard beneath northeastern Yucca Flat is probably underlain at depth principally by Precambrian clastic or crystalline basement rocks. Thus, the upper clastic aquitard need not necessarily retard the movement of some ground water into Yucca Flat from the west or northwest, because such movement could occur at depths of several thousand feet through the underlying carbonate aquifers. The effectiveness of the aquitard may depend in part on the nature of the Tippinip thrust fault (pl. $2 A$ and $C$ ). If the thrust dips steeply for several thousand feet, it could partly isolate the lower carbonate aquifer beneath the central part of the valley from 
equivalent strata to the west. If it does not dip steeply, then the ground water in the upper clastic aquitard may be semiperched above the underlying carbonate rocks.

\section{SOUTHERN INDIAN SPRINGS AND THREE LAKES VALLEYS}

Well data from southern Indian Springs Valley indicate a marked compartmentalization of the lower carbonate aquifer within a single valley and within distances of a few miles. Potentiometric contours (fig. 33) suggest two prominent west-trending hydraulic barriers between the Nye-Clark County line and Indian Springs, a distance of about 12 miles. The water-level altitude becomes lower northward (fig. 33). The position of the southerly hydraulic barrier almost coincides with the inferred position of the Las Vegas Valley shear zone (Longwell, 1960; Longwell and others, 1965) and may be created by gouge developed along this shear zone (structural feature 13 on pl. 1). The northerly barrier may result from the presence of the lower clastic aquitard within the zone of saturation north of wells $66-75$ and 67-73 (fig. 33). Observations by W. E. Hale (written commun., 1963) suggest that the difference in waterlevel altitude in this area is not due to steep gradients developed within the lower carbonate aquifer. First, water levels in the carbonate aquifer indicate a gentle gradient of about 4 feet per mile to the west. Second, pumping tests indicate coefficients of transmissibility of about 11,000 and 20,000 gpd per $\mathrm{ft}$ (table 3); steep gradients are unlikely to develop in such rocks. In other words, the lower carbonate aquifer tapped by these wells is part of a permeable block bounded on both north and south by hydraulic barriers that separate it from other aquifer blocks. Although the gross potentiometric contours of figure 33 suggest a regional northerly movement of water, the principal movement within the lower carbonate aquifer between the barriers may actually be to the west, as is the regional movement of ground water north of the barriers.

Water levels in three wells in southern Three Lakes Valley (fig. 33) also suggest a possible major hydraulic barrier parallel to the Las Vegas Valley shear zone. Wells 65-82, 65-83, and 69-84 tap the valley-fill aquifer. The average hydraulic gradient between the southerly two wells is about 85 feet per mile, whereas the average gradient between the two northerly wells is about 30 feet per mile. Hydraulic gradients in the valley-fill aquifer in surrounding valleys are commonly less than 60 feet per mile and are usually less than 30 feet per mile. The average gradient of 85 feet per mile in southern Three Lakes Valley may reflect below-average transmissibility of the valley fill, above-average quantity of water in transit through the aquifer, or a hydraulic barrier within either the valley fill or the underlying lower carbonate aquifer. An above-average quantity of water in transit through the valley fill might be due to upward leakage from the carbonate aquifer into the valley fill along a hydraulic barrier.

A short-term pumping test indicates that the specific capacity of well 65-82 is less than $1 \mathrm{gpm}$ per foot of drawdown (L. R. West, written commun., 1963). If this test is representative of the valley-fill aquifer, it might explain the rather steep hydraulic gradient; but if it does explain the gradient, equally steep gradients are also expectable between wells $65-83$ and 69-84, which are farther from the principal source of detritus, the Spring Mountains. The authors tentatively conclude that the anomalous hydraulic gradient within the valley-fill aquifer reflects a hydraulic barrier in the lower carbonate aquifer approximately parallel to and between the 3,000 - and 3,100-foot potentiometric contours of figure 33 .

A major hydraulic barrier may also exist in the vicinity of the village of Indian Springs. The valley-fill aquifer supplies Indian Springs, the major spring in the area. This spring, which discharges about $435 \mathrm{gpm}$, is about 0.5 mile north of a ridge of the lower carbonate aquifer (fig. 33). The spring is probably fed directly by upward leakage of ground water from the flanking and probably underlying lower carbonate aquifer, for the following reasons. (1) The extremely small catchment area immediately upslope from the spring can hardly yield the nearly constant discharge cited; conversely, contribution from a larger catchment area, such as the alluvial fans bordering the Spring Mountains, is precluded by the intervening unnamed carbonate-rock ridge 0.5 mile south of the spring, unless such recharge passes through the carbonate rocks; (2) water-level data presented by Maxey and Jameson (1948, app. I, p. 20-21) suggest an increase in head with increase in depth of well, which in turn suggests that the valley-fill aquifer is fed by an underlying aquifer. (3) The spring has a high-level outlet near the carbonate-rock ridge.

The topographic setting of the spring suggests either that a brimful carbonate aquifer spills over at a low point near the outcrop or that the carbonate aquifer is dammed north of but close to the spring and, hence, the water is forced to the surface. The absence of springs in topographically lower carbonate-rock outcrops north of U.S. Highway 95 probably rules out the first possibility, whereas the water level in destroyed well 68-79, (fig. 33) about 4 miles north of U.S. Highway 95, further supports the idea of a hydraulic barrier north of Indian Springs and probably north of the highway. The reported water level in this well is at least 500 feet lower than levels in the valley-fill reservoir adjacent to the highway (Carpenter, 1915).

In summary, hydraulic data in southern Indian Springs Valley indicate that the carbonate aquifer is compartmentalized by two ground-water dams or barriers; the northern barrier appears to be due to juxtaposition of the lower clastic aquitard and the lower car- 


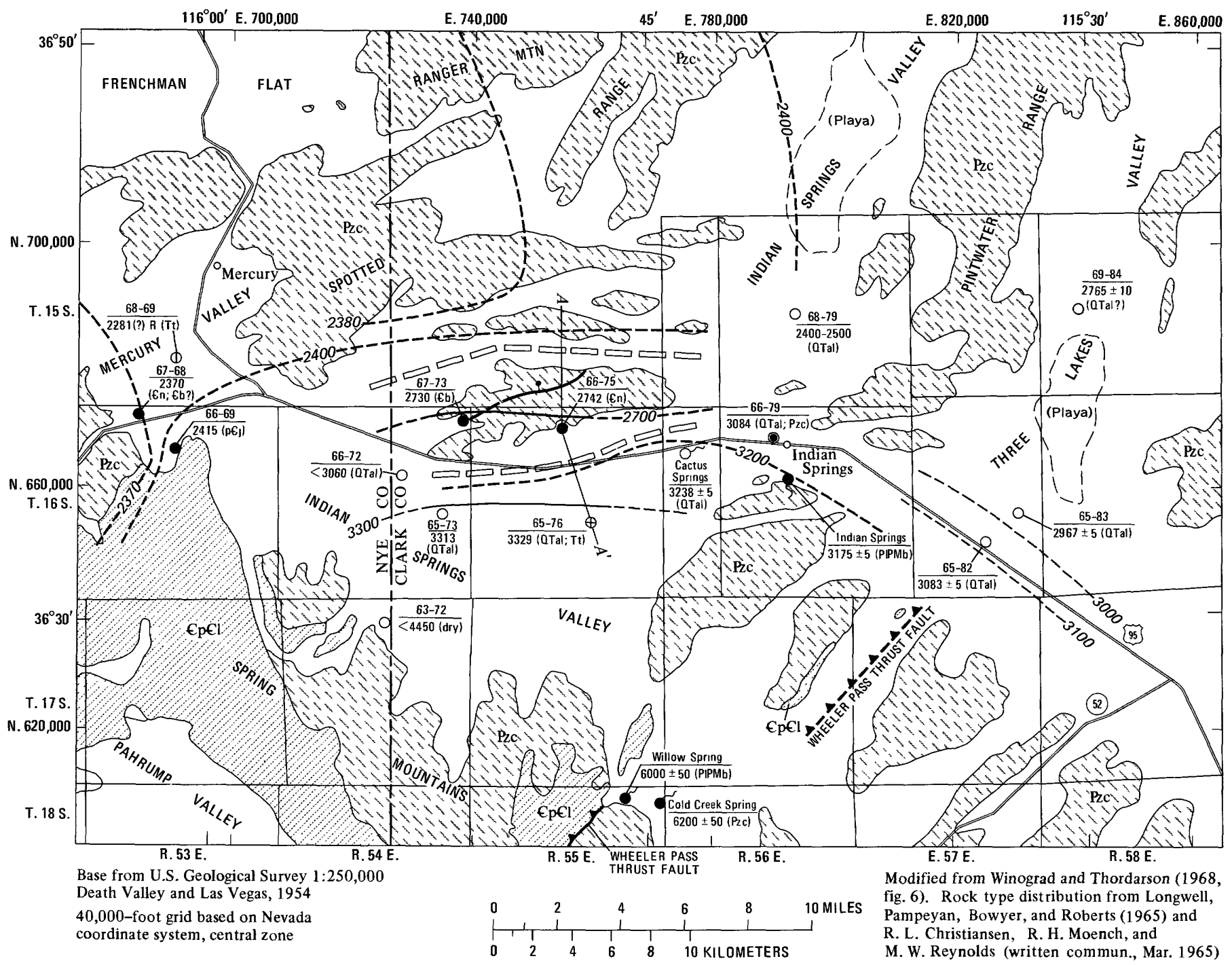

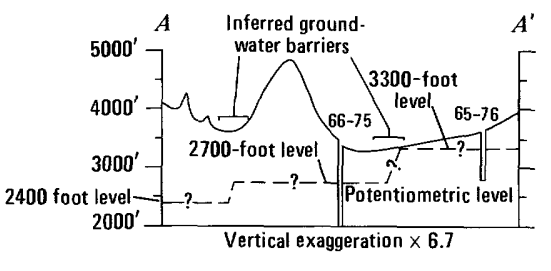

HYDRAULIC SECTION

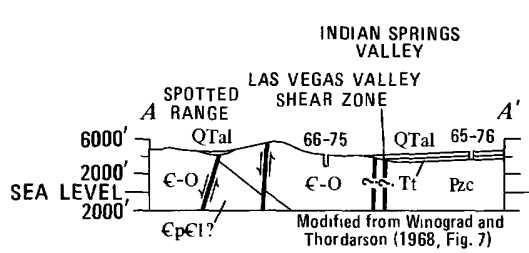

GEOLOGIC SECTION

FIGURE 33. - Hydrogeology of southern Indian Springs Valley.

bonate aquifer (fig. 33), whereas the southern barrier appears to be related to the Las Vegas Valley shear zone and may be due to gouge developed along the major fault zone. Well data near the village of Indian Springs and in southern Three Lakes Valley suggest additional hydraulic barriers which approximately parallel the Las Vegas Valley shear zone (Longwell, 1960; Longwell and others, 1965). Whether these barriers are due to the juxtaposition of the clastic aquitard and the carbonate aquifers, to the development of gouge along the shear zone, to the dragging of the clastic strata into the shear zone, or a combination of these mechanisms is unknown.

\section{SOUTHWESTERN MERCURY VALLEY}

Two wells in southwestern Mercury Valley (fig. 33) provide another example of the hydrologic effect of juxtaposition of the lower clastic aquitard and the lower carbonate aquifer. Well 66-69 was drilled into the lower clastic aquitard (Johnnie Formation). The water-level altitude in this well is 2,415 feet above mean sea level. 


\section{EXPLANATION}

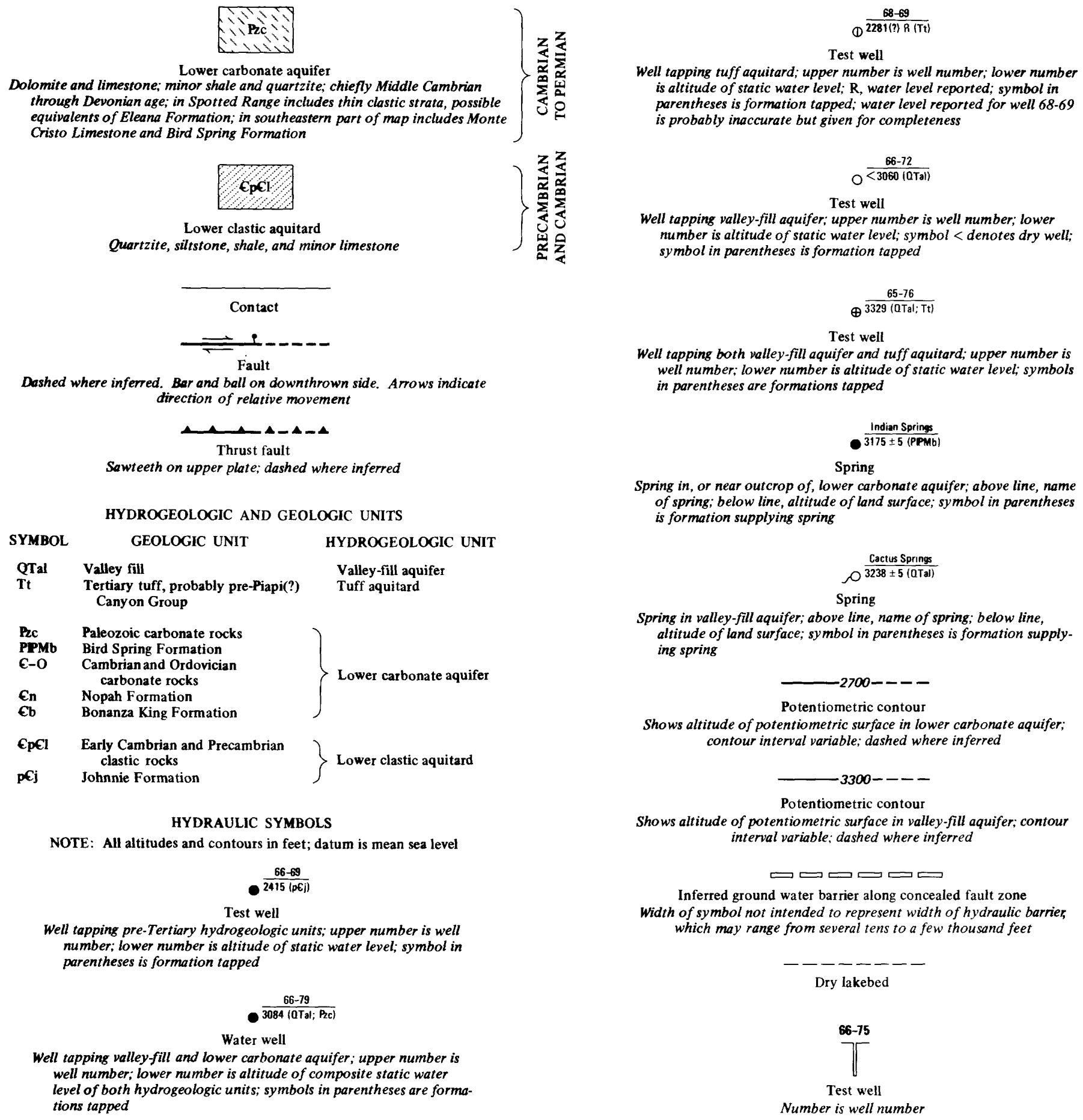

Figure 33. - Continued.

Well 67-68, about 1.5 miles northwest of well 66-69, was drilled into the lower carbonate aquifer (Nopah Formation and Bonanza King(?) Formation). The water-level altitude in this well is 2,370 feet above mean sea level, or about 45 feet lower than the level in the adjacent well. The difference in levels does not appear striking until the aquitard. water level in the lower carbonate aquifer, about 30 miles away, in central Yucca Flat is noted to be only 17 feet higher (alt 2,387 ft) than in well 67-68. The authors believe that the higher water level in well 66-69 reflects the low gross transmissibility of the lower clastic 


\section{ASH MEADOWS}

The most striking example of structural control of ground-water movement within the lower carbonate aquifer is the spring line at Ash Meadows in east-central Amargosa Desert (pl. 1). These springs aline for about 10 miles in a northwesterly direction. This trend parallels the strike of the lower carbonate aquifer as well as a major fault zone delineated by a gravity survey of the region (D. L. Healey and C. H. Miller, written commun., 1965). The spring line and the details of the individual springs are discussed in the section "Character and Geologic Control of Spring Discharge."

\section{GENERAL SIGNIFICANCE OF THE HYDRAULIC BARRIERS}

The hydraulic barriers cited suggest the presence of ground-water dams not shown by the potentiometric levels and contours. Hydraulic compartmentalization of the lower carbonate aquifer is expectable throughout the study area owing to the complex geologic structure. Some areas, for example the area between eastern Frenchman Flat and Ash Meadows (pl. 1), are seemingly free of compartmentalization of the lower carbonate aquifer. However, the absence of hydraulic barriers in this area is probably only apparent. The examples of compartmentalization discussed in this chapter were chosen specifically because adequate well and geologic control was available to demonstrate clearly the role of the clastic rocks and perhaps that of the major shear zones in controlling regional ground-water movement through the lower carbonate aquifer. Actually, the hydraulic barriers cited could have been detected from the water-level data alone, without the aid of areal geologic mapping or subsurface stratigraphic control. But, the examples cited were chosen from areas close to the margins of the flow system, where significant differences in water level occur across the hydraulic barriers. In other areas, such as Yucca and Frenchman Flats and the region between Frenchman Flat and Ash Meadows, the total drop in head within the lower carbonate aquifer is only a few feet. Consequently, detection of clastic-rock or fault barriers in such areas will probably be impossible without considerable subsurface control. For example, the head within a ridge of clastic rocks buried beneath a valley but surrounded by carbonate rocks would probably be controlled by and consequently be the same or nearly the same as that within the adjacent carbonate aquifer. In this situation, waterlevel data alone might not permit identification of the clastic barrier. Similarly, major fault zones, independently of clastic strata, may locally compartmentalize the carbonate aquifer in the area between central Yucca Flat and the Amargosa Desert; but evidence of such fault barriers would not be apparent on the potentiometric map. Water levels in four wells tapping the lower carbonate aquifer in eastern Amargosa Desert suggest that compartmentalization may also occur in areas of low hydraulic gradient. All four wells are in the NW $1 / 4$ sec. 27, T. 16 S., R. 51 E., and only 400 feet separates the two most widely spaced wells (the location of one of these wells is shown on pl. 1 and fig. 34). Depth to water is about 42 feet. Static levels in the three westernmost wells are within 0.2 foot of each other, but the level in the easternmost well is 0.5 to 0.7 foot lower than in the other wells (R. H. Johnston, written commun., May 1967). Flowmeter surveys indicating no flow in the bore of the anomalous well preclude downward movement as an explanation for the discrepancy. A possible reason for the discrepancy is a hydraulic barrier(s) between the easternmost well and the three other wells.

Awareness of the probable occurrence of numerous hydraulic barriers in the lower carbonate aquifer is extremely important for a realistic interpretation of the regional potentiometric map (pl. 1). First, the change in head between wells plotted on the potentiometric map may locally be steplike, rather than smooth, because the lower carbonate aquifer is probably compartmentalized locally by fault or clastic-rock barriers throughout the study area; the actual hydraulic gradients, therefore, may be considerably smaller between barriers, but larger across the barriers, than gradients shown on plate 1 . Second, because of the known, and probably numerous unknown, hydraulic barriers cutting the lower carbonate aquifer, the potentiometric contours may best be regarded as illustrating the direction of decrease in head within a compartmentalized aquifer system rather than the exact direction of ground-water movement. Although the regional movement of water in the aquifer is probably roughly at right angles to the potentiometric contours as drawn, local movement may depart greatly from the regional average owing to either the anisotropy and heterogeneity of the aquifer, the presence of hydraulic barriers, or both. In the vicinity of some major hydraulic barriers, ground water may move parallel to, rather than across, the barriers. However, because of the prominent difference in water level on opposite sides of a barrier and because of the sparsity of well data, the potentiometric contours drawn for such areas may suggest flow at right angles to the barrier. For example, in southern Indian Springs Valley (fig. 33) ground-water flow between the two hydraulic barriers may actually be principally to the west rather than to the north as suggested by the 500 -foot potentiometric contours.

The tightness of the hydraulic barriers is probably highly variable. Where the lower carbonate aquifer is completely surrounded by the lower clastic aquitard, as in western Emigrant Valley, it is probable that little water moves across the barrier despite large differences (in places as great as 2,000 ft) in head. On the other 
hand, where the lower carbonate aquifer is only partly juxtaposed against a clastic (or tuff) aquitard or contains a barrier formed chiefly by gouge developed along a major shear zone within the aquifer, the situation differs; here a prominent difference in head need not necessarily preclude the movement of important quantities of water across the barrier. The author's judgment on the tightness of specific barriers is discussed at appropriate places in the text.

\section{CONSTRUCTION AND INTERPRETATION OF THE POTENTIOMETRIC MAP OF THE LOWER CARBONATE AQUIFER}

NOTES ON CONSTRUCTION

Two assumptions are generally made during construction of the potentiometric map of an aquifer: (1) the water levels used represent only head in the aquifer of interest; and (2) in the vicinity of the control wells, water flows nearly horizontally through the aquifer. These assumptions are generally fulfilled in the lower carbonate aquifer. First, because the key wells used in constructing the potentiometric map were drilled specifically for the hydrologic study program, they permitted careful control on the measurement of potentiometric levels. Second, drill-stem tests and flowmeter surveys indicate that flow in the lower carbonate aquifer is probably horizontal in the vicinity of the key wells.

The potentiometric maps of the lower carbonate aquifer for Yucca Flat (pl. 2C) and for the entire area (pl. 1) represent a synthesis of both hydraulic and geologic data. Briefly, these maps were constructed as follows. First, water-level contour maps were drawn using only water-level data for the lower carbonate aquifer. On another pair of maps, outcrops of both the upper and the lower clastic aquitards were drawn; in addition, areas where the clastic aquitards were likely to be the major or only pre-Tertiary rock within the zone of saturation were delineated. Next, on the assumptions that the clastic aquitards are considerably less permeable than the carbonate aquifers and that the lower clastic aquitard is the effective hydraulic basement for ground-water flow, the contours were modified as follows: Where the contours crossed into areas underlain by clastic rocks the contours were sharply bent (refracted) to indicate the probable steeper hydraulic gradients within the clastic aquitards. In areas where major water-level anomalies and geologic mapping or gravity surveys suggested major discontinuities, hydraulic barriers were shown. Thus, the potentiometric maps represent a synthesis of hydraulic, geologic, and geophysical data. Such a synthesis was both reasonable and essential because contouring of the water-level data without regard for geologic structure led to several improbable local hydrologic conditions. In any event, the major features (discussed in the next section) of the initial water-level contour map surprisingly were not greatly affected by the synthesis with the geologic and geophysical data.

Contours of the potentiometric surface in the Cenozoic aquifers are also drawn on the regional potentiometric map (pl. 1) for areas surrounding Nevada Test Site. In some areas, these contours probably reflect the head in the underlying lower carbonate aquifer; in other areas they offer clues to the position of ground-water divides within the clastic aquitards.

Several mechanical matters evaluated during the construction of the contour map were (1) accuracy of measurement of deep water levels, (2) effects of hole crookedness and water-column density on water-level measurement, and (3) effects of previous pumpage on the static water levels measured. A discussion of the first two items is presented by Garber and Koopman (1968) and Winograd (1970).

The accuracy of the water-level measurements was satisfactory for potentiometric contouring at the 10 - and 20 -foot intervals used on plates 1 and 2 .

\section{INTERPRETATION OF MAJOR FEATURES OF POTENTIOMETRIC MAP}

Major features shown on the regional potentiometric map (pl. 1) are the trough in the potentiometric surface in Yucca Flat and the major trough that extends from eastern Frenchman Flat to the Ash Meadows discharge area in east-central Amargosa Desert.

The potentiometric surface within the lower carbonate aquifer in Yucca Flat is marked by a prominent northnorthwest trending trough about 20 miles long and 2 to 8 miles wide (pl. $2 \mathrm{C}$ ). The apparent hydraulic gradient along the axis of the trough ranges from a fraction of a foot to 5.9 feet per mile. (See section on pl. 1.) The apparent gradient along the flanks of the trough is as much as 20 feet per mile. At its south end, the trough merges with the major southwest-trending trough. The water levels in wells $84-68 \mathrm{~d}$ and $85-68$ suggest a possible reversal of hydraulic gradient within the trough in Yucca Flat. Neglecting correction of the water levels for temperature, the level in the southerly well $(84-68 \mathrm{~d})$ is 1 foot higher than that in the northerly well $(85-68)$. This condition suggests a very low northerly gradient. However, the water-level altitude calculated after correcting the water column in well $84-68 \mathrm{~d}$ for density is the same as that in well 85-68. The water level in destroyed well 85-68 was not corrected for temperature, because temperature data were not obtained; if such a correction had been made, it would probably have resulted in a water-level altitude several feet higher than that in well 84-68d. In any event, a reversal in gradient in Yucca Flat seems unlikely because of other water levels in the valley.

The trough within the lower carbonate aquifer in Yuc- 
ca Flat may reflect variations in the transmissibility of the lower carbonate aquifer, or it may be due to a series of subparallel northward-trending hydraulic barriers. The saturated thickness of the carbonate aquifer increases westward between the east margin and the central part of Yucca Flat (pl. 2A). Near the east margin of the valley, only the lowest part of the aquifer (the Bonanza King Formation) is saturated, whereas toward the west, successively overlying formations are saturated; that is, westward from the east margin of saturated carbonate rocks, the saturated thickness probably increases from a few hundred feet to possibly more than 10,000 feet. If this increase in thickness is accompanied by even a moderate increase in transmissibility, it could explain the general position of the trough. Alternately, because the trough crudely parallels the Yucca fault, movement along this major fault may have resulted in above-average fracture transmissibility within the lower carbonate aquifer beneath the center of the valley. However, available well data are too scant to support or refute the relationship of aquifer transmissibility to the Yucca fault or to any other fault zone.

The extremely low hydraulic gradients along the center of the trough do not necessarily reflect high transmissibility. Low hydraulic gradients can be due to high transmissibility or a small quantity of water moving through the aquifer, or to a combination of both factors. In Yucca Flat the quantity of water moving through the system is small, probably less than 350 acre-feet annually. (Estimates of the quantity of water moving through the aquifer in Yucca Flat are developed in the section "Sources of Recharge to the Lower Carbonate Aquifer.") Thus the very low gradient in the center of the trough need not reflect high transmissibility, only a transmissibility possibly greater than that along the margins of the trough.

The trough also might reflect hydraulic barriers due to faults within the lower carbonate aquifer. The regional strike of major block faults cutting the lower carbonate and of bedding in the blocks is northward and northwestward. Underflow to the lower carbonate aquifer is from both the east and the west, via the clastic aquitards, and also from the overlying Cenozoic rocks. If the northward-striking faults, possibly aided by the thin clastic rocks within the aquifer, deflect only part of the underflow southward (or parallel to the fault planes), another explanation for the trough is possible. Namely, southward diversion of some of the recharge by the block faults, which dropped the aquifer as much as 4,000 feet below the valley floor, would result in only a fraction of the total recharge entering and moving southward within the structurally deepest blocks of aquifer. The reduction in quantity of flow carried by the carbonate rocks beneath the center of the valley would of necessity be ac- companied by a lower potentiometric level if transmissibility were constant.

Subsurface information and transmissibility data available in 1965 (table 3) are insufficient to indicate which of the conditions, or what combination of conditions, is causing the trough within the lower carbonate aquifer beneath Yucca Flat. The authors favor the last of the three explanations.

The second major feature of the potentiometric map is the trough that runs from east-central Frenchman Flat to Ash Meadows (pl. 1), a distance of about 40 miles. This trough is roughly outlined on the northwest and east by the 2,380-foot potentiometric contour (pl. 1) and on the south by the 2,400-foot contour. It is about 15 miles wide at the Ash Meadows discharge area; about 5 miles wide beneath the Specter Range; and possibly as much as 20 miles wide within the Nevada Test Site, where its width is not well defined. The hydraulic gradients within this trough range from 0.3 to about 1.5 feet per mile. The trough indicates that ground water within the lower carbonate aquifer beneath Yucca, Frenchman, and eastern Jackass Flats and beneath a vast area east, northeast, and southeast of the Nevada Test Site is moving toward a prominent spring-discharge area (Ash Meadows) in the east-central Amargosa Desert.

That the part of the trough between the Specter Range and Ash Meadows (pl. 1) represents a region of very high transmissibility ( 1 to several million gpd per $\mathrm{ft}$ ) is discussed in the next section of the report.

The high transmissibility of the carbonate rocks beneath and southwest of the Specter Range may be due to a greater thickness of aquifer, to a higher degree of fracturing than found elsewhere in the study area, or to a combination of both. Several cross sections through the Specter Range (R. L. Christiansen, R. H. Moench, and M. W. Reynolds, written commun., Mar. 1965) indicate that the saturated thickness of the lower carbonate aquifer beneath the Specter Range probably ranges from 5,000 to 8,000 feet. This thickness is more than double that at some well sites; however, thickness alone cannot account for the difference in transmissibility which, beneath the Specter Range, is two to three orders of magnitude greater than that at 8 of 10 well sites. The increase in transmissibility must, therefore, be due to above-average fracture transmissibility.

Geologic mapping suggests that the Specter Range may, in general, be structurally more complex than most of the ridges and hills within the study area (Burchfiel, 1965; Christiansen, Moench, and Reynolds, written commun., Mar. 1965). Most of the fault-block ridges of preTertiary rocks at the Nevada Test Site are of simple structure, even though the rocks themselves are highly fractured. The Specter Range, by contrast, appears to be a mosaic of fault blocks. Possible reasons for the intense 
deformation of the Specter Range strata were presented by Burchfiel (1965), Stewart (1967), and Albers (1967). They noted that the Las Vegas Valley shear zone seemingly dies out east of the Specter Range quadrangle (pl. 1), and they attributed the unexpected disappearance of this major shear zone to large-scale bending of the miogeosynclinal rocks. That is, southeast of the Specter Range, the shear zone, which is probably a deep-seated strike-slip structure, cuts and displaces the miogeosynclinal strata 25 to 40 miles; but in the longitude of the Specter Range, the strike-slip movement is taken up in the sedimentary cover by large-scale bending (Albers, 1967). Evidence for this bending northeast of the Specter Range is shown by the change in strike of the axes of major folds in the pre-Tertiary rocks (pl. 1). Figure 6 of Stewart (1967) and figure 4 of Albers (1967) suggest that the axis of the Spotted Range syncline (structural feature 7 on $\mathrm{pl}$. 1) swings sharply to the southwest and the south after passing through the Specter Range. If their interpretation is correct, intense fracturing of the pre-Tertiary rocks would be expectable in the Specter Range area, because fracturing is commonly most intense near the crest of flexures.

A possible related explanation for the intense fracturing is suggested by the axes of the Spotted Range syncline and the Pintwater Range anticline (structural features 7 and 8 on pl. 1). The axes of these folds converge as they approach the Specter Range. If both axes pass through the Specter Range area, the carbonate rocks now forming the range were subjected to relatively tight folding with probable attendant intense fracturing. Regardless of the interpretation favored, the Specter Range lies at the intersection of two major structural trends - the Las Vegas Valley shear zone and the Spotted Range syncline (pl. 1). The high fracture transmissibility of the lower carbonate aquifer beneath the Specter Range is probably directly related to the complex deformation of the aquifer in this area.

The very high transmissibility of that part of the major potentiometric trough between the Specter Range and the Ash Meadows discharge area may be due in part to downfaulted and buried segments of the upper plate of the Specter Range thrust (structural feature 19 on pl. 1) and (or) the presence of solution channels, particularly near the discharge area. Four wells drilled in the NW $1 / 4$ sec. 27 , T. 16 S., R. 51 E., penetrated a possible thin thrust plate of Bonanza King Formation overlying the Carrara Formation. This thrust plate may be part of the upper plate of the Specter Range thrust fault (pl. 1). If this upper plate is widespread elsewhere beneath the trough and consists principally of carbonate rocks, it could significantly increase the gross transmissibility of the lower carbonate aquifer in this area.

Northeast of the Specter Range the trough is poorly defined. The trough appears to widen greatly from about 5 miles beneath the Specter Range to perhaps as much as 20 miles beneath eastern Frenchman Flat. Prediction of the possible effects of particular geologic structures on the distribution of transmissibility within the trough in this area would be difficult.

\section{LOWER CARBONATE AQUIFER TRANSMISSIBILITY DERIVED} FROM MAP

The potentiometric map can be used to calculate the gross fracture transmissibility of the lower carbonate aquifer underlying the Specter Range and other areas. The Specter Range area is particularly well suited for such a determination because both the width and the depth of the aquifer, the hydraulic gradient, and the volume of water moving through the system are known within reasonable limits. Geologic sections through the Specter Range, prepared by R. L. Christiansen, R. H. Moench, and M. W. Reynolds (written commun., Mar. 1965 ), indicate that the average width of saturated lower carbonate aquifer beneath the range generally ranges from 4.5 to 7 miles; the saturated thickness generally ranges from 5,000 to 8,000 feet. The hydraulic gradient between well 67-68, northeast of the Specter Range, and well $65-62$, southwest of the range (pl. 1 ), is 0.9 foot per mile. This gradient assumes the absence of any hydraulic barriers between the two wells. The volume of water flowing through the Specter Range along the lines of cross section is considered equal to the average measured spring discharge at Ash Meadows, about $10,600 \mathrm{gpm}$, or about 17,100 acre-feet annually (table 7). That the discharge cited is probably a minimum and that practically all the measured discharge passes through this underflow strip will be established in the section "Ash Meadows Ground-Water Basin."

The gross transmissibility of the lower carbonate aquifer beneath the Specter Range is calculated using the above information and the equation $Q=T I W$, or $T=\frac{Q}{I W}$, where $Q$ is discharge, in gallons per day; $I$ is hydraulic gradient, in feet per mile; $W$ is width of the underflow strip, in miles; and $T$ is coefficient of transmissibility, gallons per day per foot. Using an average width of 5.8 miles, the gross transmissibility is about $3 \times 10^{6}$ gpd per $\mathrm{ft}$. This value is probably a maximum because the hydraulic gradient beneath the Specter Range (where the trough is narrowest) may be two or three times that used.

The gross transmissibility of the aquifer within the trough between the Specter Range and the Ash Meadows discharge area is also in the millions. The apparent hydraulic gradient in this area is about 0.3 foot per mile (pl. 1). Using this gradient, underflow strips 8 to 14 miles wide, and the same discharge, the calculated coefficient 
of transmissibility roughly ranges from $4 \times 10^{6}$ to $6 \times 10^{6}$ gpd per $\mathrm{ft}$. Based on the geologic mapping of R. L. Christiansen, R. H. Moench, and M. W. Reynolds (written commun., Mar. 1965), the thickness of carbonate rocks beneath this segment of the trough may be expected to range from a few hundred feet near the lower clastic aquitard, on the southeast border (pl. 1) of the trough, to more than 8,000 feet near the lower clastic aquitard, on the northwest border of the trough.

The coefficient of transmissibility of the aquifer within the trough between the Specter Range and Mercury Ridge (fig. 1), beneath Mercury Valley, cannot readily be calculated, because the exact width of the trough is poorly defined and the trough receives some recharge from the southeast and the northwest in this reach. Nevertheless, the trough's position within the regional flow system and its low hydraulic gradient suggest that the lower carbonate aquifer beneath at least parts of the area probably has a gross coefficient of transmissibility of greater than a million gallons per day per foot.

Northeast of Mercury Ridge the major trough is poorly defined and probably receives recharge from the north, the northeast, the east, and the southeast. The coefficient of transmissibility cannot be calculated because neither the volume of water entering from each direction nor the place of entry is well known.

The coefficient of transmissibility of the lower carbonate aquifer at the sites of wells 67-68 and 75-73 (figs. 33 and 31 ) is unexpectedly low (table 3 ) in comparison with the coefficients of transmissibility inferred for the aquifer beneath the major trough in the potentiometric surface. Transmissibility of the aquifer in well $67-68$ is about 39,000 gpd per $\mathrm{ft}$, and that in well $75-73$ is about $3,800 \mathrm{gpd}$ per $\mathrm{ft}$ (table 3 ). Both wells are in or along the margin of the potentiometric trough. The discrepancy may reflect the presence of aquifer blocks of low to moderate transmissibility interspersed with highly permeable blocks which control the regional potentiometric levels within the trough. The time-drawdown plot for well 67-68 shows a hydraulic barrier (fig. 11), as does an expanded-scale plot of data for well 75-73. These barriers could preclude sampling of the surrounding aquifer blocks of high transmissibility. In contrast to data from these wells, data from wells 79-69 and 79-69a at the southern tip of Yucca Flat and one of a group of four wells southwest of the Specter Range in the NW $1 / 4$ sec. 27, T. 16 S., R. 51 E. (fig. 34), also in the trough, suggest minimum coefficients of transmissibility of 200,000 to 900,000 gpd per $\mathrm{ft}$.

The coefficient of transmissibility of the lower carbonate aquifer beneath central Yucca Flat probably averages less than 10,000 gpd per $\mathrm{ft}$. In this valley, the low hydraulic gradient indicates relatively minor underflow (less than 350 acre-ft per yr) moving through the system rather than high transmissibility of the aquifer.

\section{DEPTH OF GROUND-WATER CIRCULATION}

Saturated thickness of the lower carbonate aquifer is several thousand feet throughout much of the study area and probably exceeds 10,000 feet in parts of the region. Depth of ground-water circulation in the lower carbonate aquifer is in part a function of the variation in fracture transmissibility with depth and the degree of continuity of the relatively thin clastic aquitards (Dunderberg Shale Member of the Nopah Formation, Ninemile Formation, and Eureka Quartzite) interbedded within the aquifer (table 1).

Drill-stem test data suggest that at least the upper 1,500 feet of the lower carbonate aquifer contains open and interconnected fractures and that there is no apparent decrease in fracture yield with depth. (See section "Lower Carbonate Aquifer.") Data from other areas in the miogeosyncline indicate that water-bearing fractures are open to depths far in excess of 1,500 feet below the top of a Paleozoic carbonate-rock sequence equivalent in age to the strata composing the lower carbonate aquifer. In the Eureka mining district, Stuart (1955) reported that the entry of large quantities of water from carbonate rocks (equivalent to the lower carbonate aquifer) at the 2,250-foot level flooded the Fad shaft. Drill-stem tests of the Paleozoic carbonate rocks in oil-test wells in western White Pine County indicate open fractures and fresh ground water at depths of as much as 9,400 feet below the top of the carbonate rock sequence (McJannett and Clark, 1960).

In some areas where carbonate aquifers are nearly undeformed as in parts of the Appalachian Plateau, circulation of ground water is retarded at the top of the first interbedded clastic stratum that lies below the altitude of the deepest surface drainage. This condition does not prevail at Nevada Test Site and vicinity because the carbonate rocks are highly fractured and faulted. Detailed geologic mapping (1:24,000 scale) at Nevada Test Site shows that the relatively thin clastic strata included within the lower carbonate aquifer are commonly offset by normal faults and minor strike-slip faults of far greater displacement than the thickness of these units. Therefore, these clastic strata probably do not significantly influence the depth of circulation in the aquifer on a regional scale.

Several intuitive reasons suggest that fracture transmissibility should decrease markedly with depth. Moderate to high transmissibility of dense carbonate rocks is commonly accepted as being due largely to secondary porosity developed along fractures by solution. Solution of the carbonate rock within the zone of saturation is principally a function of initial carbon dioxide content at the water table, rate of flow, pressure, and temperature. However, because the primary source of carbon dioxide is the soil zone, the concentration of car- 
bonic acid in ground water normally may be expected to decrease both with depth in the aquifer and with distance from major recharge areas. In addition, owing to the relatively great depth to water within the lower carbonate aquifer, one may argue that little vadose water laden with carbon dioxide reaches the aquifer within the zone of saturation. First, precipitation on ridges would have to pass through several hundred to more than a thousand feet of unsaturated carbonate rock; solution of carbonate rock during passage through this vadose zone might deplete some or most of the carbon dioxide. Second, recharge to the valley floors would have to pass through hundreds of feet of Cenozoic aquifers and aquitards before it could enter the carbonate aquifer, and the rate of such movement would be extremely slow.

The preceding reasons for possible decrease in fracture transmissibility with depth neglected several important factors. First, climate, topography, and structural position of the Paleozoic carbonate rocks varied greatly between Permian and Pliocene time. For example, the absence of Mesozoic sedimentary rocks and the moderate relief developed on the Paleozoic rocks before deposition of the Tertiary tuffs and lake beds might have been conducive to moderately deep circulation of ground water in late Mesozoic and early Tertiary time, particularly if the climate was subhumid to humid. (Admittedly, the absence of evidence for karstification beneath the Tertiary-Paleozoic unconformity does not support the postulated climatic conditions.) Second, the arguments treated the carbonate aquifer as an isotropic reservoir and neglected the possible effect of anisotropy on depth of circulation. For example, vadose water may move vertically, more rapidly, and to greater depth in the carbonate aquifer that is highly shattered, as beneath the Specter Range, than in the aquifer elsewhere in the study area.

Resolution of the question of depth of circulation within the lower carbonate aquifer must await drilling through and detailed drill-stem testing of the aquifer. Locally, the entire thickness of aquifer may have significant fracture transmissibility; thus, in the lower carbonate aquifer, water may be flowing to depths of thousands of feet beneath the top of the aquifer, or down to the lower clastic aquitard, the "hydraulic basement."

\section{ASH MEADOWS GROUND-WATER BASIN}

The regional potentiometric map (pl. 1) indicates that ground water beneath Nevada Test Site is tributary to three major discharge areas: (1) Ash Meadows, in the east-central part of the Amargosa Desert; (2) Alkali Flat, near Death Valley Junction in southern Amargosa Desert; and (3) Oasis Valley, between Beatty and Springdale.

The Ash Meadows ground-water basin is defined as that area contributing ground water to the springs at Ash Meadows (fig. 1).

\section{DISCHARGE AREA}

A prominent spring line in the southeastern and eastcentral part of the Amargosa Desert (Tps. 16-18 S., Rs. 50-51 E.), an area called Ash Meadows, is the dominant feature of the discharge area of the Ash Meadows ground-water basin. The hydrogeologic setting is given in figure 34 . The discharge area consists of the spring line and an unnamed valley northeast of the spring line. The valley contains a playa saturated to within a few feet of the surface (T. $17 \mathrm{~S}$., R. $51 \mathrm{E}$ ). The playa is drained to the west by a tributary of Carson Slough (fig. 34). The unnamed valley is bordered on the north by the Specter Range and the Skeleton Hills, on the east by the northwest end of the Spring Mountains, and on the south and the southwest by several low ridges of preTertiary rocks. On the west, in the vicinity of the spring line, the valley merges with the main part of the Amargosa Desert. The altitude of the playa is about 2,331 feet, and that of the surrounding ridges generally ranges from 3,000 to 6,000 feet above mean sea level.

The valley northeast of the spring line is bordered by prominent structural features as shown on plate 1 and in figure 34. The Specter Range thrust fault, which brings tightly folded Middle Cambrian and Precambrian carbonate and clastic rocks over Ordovician ihrough Devonian carbonate rocks, borders the discharge area on the northwest (fig. 34). The Montgomery thrust (Hamill, 1966), which brings Lower Cambrian and Precambrian clastic rocks over Ordovician to Devonian carbonate rocks, borders the area on the southeast. On the southwest, the discharge area is bordered by a major normal fault that was identified by the gravity survey of the area. The normal fault (pl. 1) extends from Big Spring on the southeast to a point about 5 miles north-northeast of Lathrop Wells. D. L. Healey and C. H. Miller (written commun., Mar. 1965) estimated that the displacement along this fault or fault zone (downthrown on the west) ranges from 500 to 1,500 feet in the vicinity of Lathrop Wells and is several thousand feet near Big Spring. The hydraulic barrier, the boundary of the Ash Meadows basin, and the normal fault shown on plate 1 (Ash Meadows area) are actually coincident but are separated on the plate for clarity. The actual position of the normal fault is best approximated by the trend of the hydraulic barrier.

The gravity survey indicates that Quaternary and Tertiary rocks beneath the unnamed valley northeast of the spring line may be as much as 3,500 to 5,000 thick and that the structurally deepest part of this valley is immediately northwest of the northwest edge of the playa. The survey also indicates, as do the outcrops, that the 


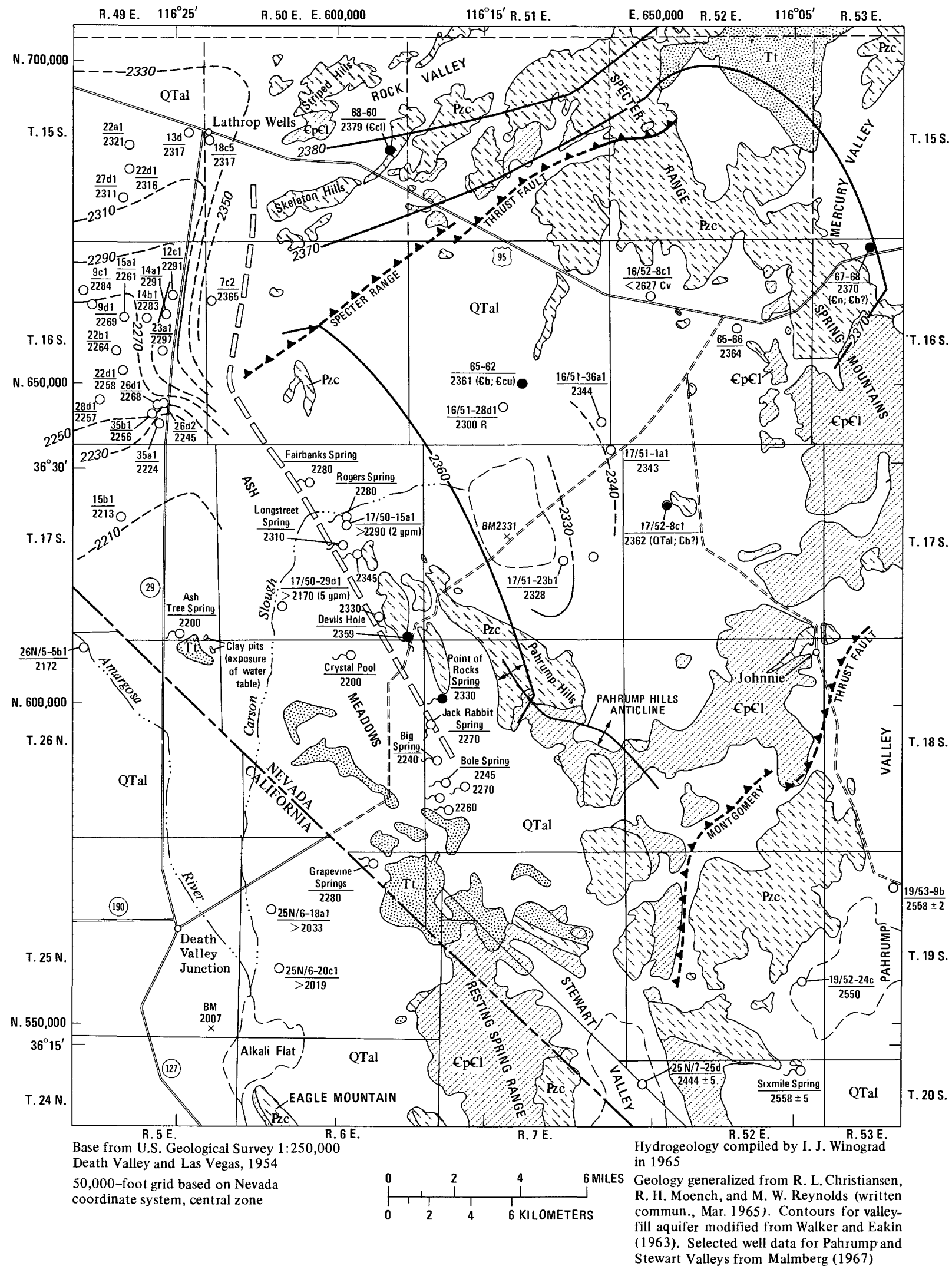

FiguRE 34. - Hydrogeology of southeastern Amargosa Desert. 


\section{EXPLANATION}

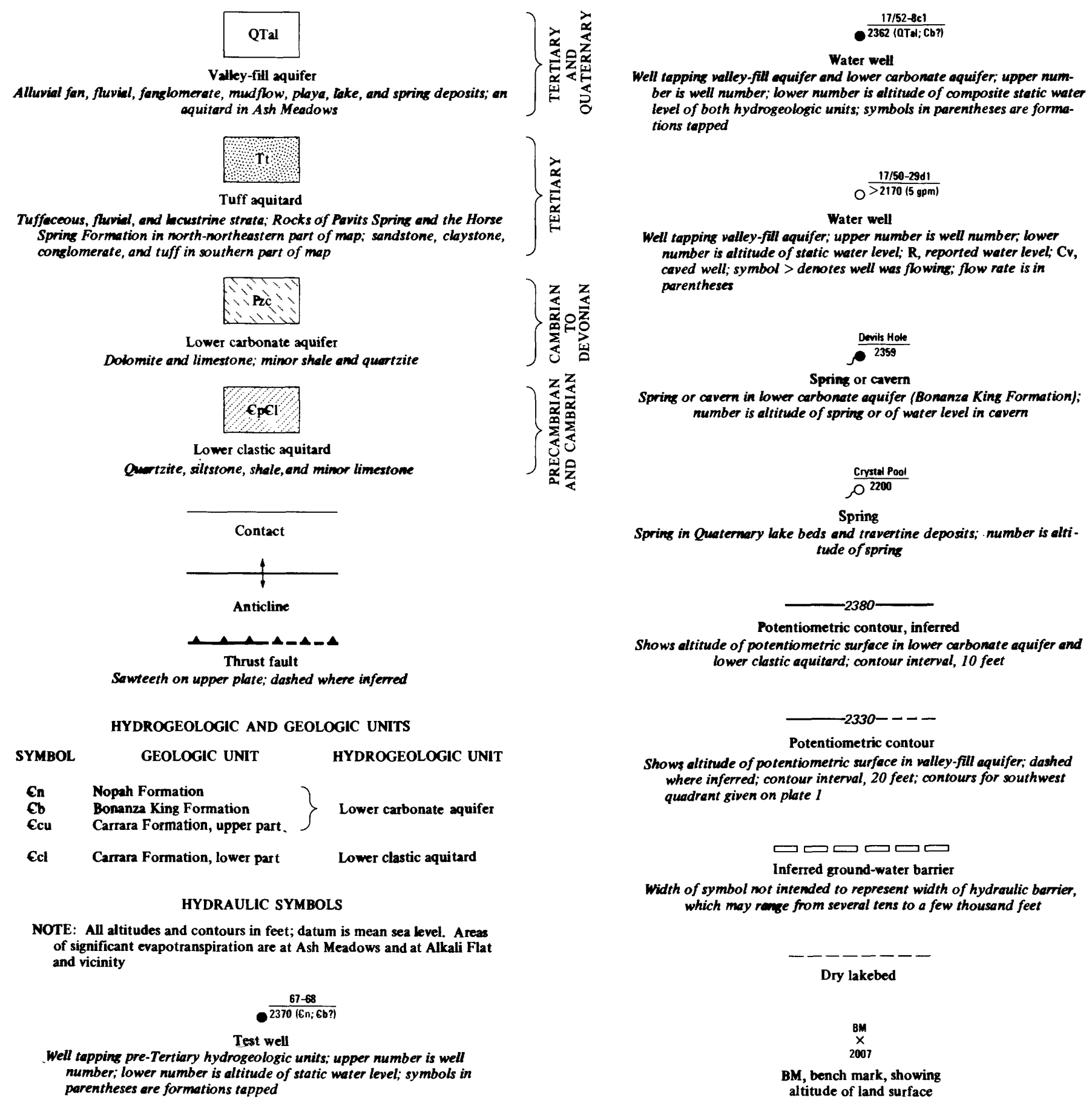

FiguRE 34. - Continued.

pre-Tertiary rocks form a continuous partly buried ridge extending northward from Rogers Spring toward the Skeleton Hills.

The areal distribution of the lower carbonate aquifer and the lower clastic aquitard in the discharge area and the relation of their distribution to the Specter Range and Montgomery thrusts are shown by figure 34; the in- ferred distribution of the clastic aquitard within the zone of saturation is shown on plate 1 .

The hydrologic character of the Tertiary rocks beneath the unnamed valley northeast of the spring line and beneath the region immediately southwest of the spring line are not well known, but available information suggests that these rocks are probably related to 
and are as impermeable as the tuff aquitard beneath the Nevada Test Site. Along the north border of the unnamed valley the Tertiary rocks consist of the Rocks of Pavits Spring and the Horse Spring Formation, which are part of the tuff aquitard (table 1). Near the center of the unnamed valley, rocks directly overlying the lower carbonate aquifer in four holes drilled in NW $1 / 4$ sec. 27 , T. 16 S., R. 51 E., consist of 250 to 310 feet of highly impermeable silty and clayey tuffaceous sandstone overlain by 10 to 80 feet of basalt (Johnston, 1968).

Both geologic mapping (Denny and Drewes, 1965) and the configuration of potentiometric contours of the valley-fill aquifer suggest that the Tertiary rocks south and southwest of the spring line are aquitards. Near the north end of the Resting Spring Range (fig. 34), Denny and Drewes described 800 feet of "fairly cemented boulder fanglomerate" resting with angular unconformity on Precambrian quartzite. Overlying the fanglomerate is 2,000 feet of fine-grained clastic rocks consisting of sandstone, claystone, and subordinate amounts of conglomerate, siltstone, tuff, and freshwater limestone. Their work suggests that the Tertiary rocks at the south end of the spring line are probably chiefly aquitards. That the Tertiary rocks southwest of the spring line are aquitards is also suggested by geologic and potentiometric maps for the area near the intersection of State Highway 29 and the Nevada-California line (pl. 1). The maps show a significant tightening of potentiometric contours for the valley-fill aquifer (pl. 1) near the northwesternmost outcrop of Tertiary rocks shown on the geologic maps (Denny and Drewes, 1965; R. H. Moench, written commun., Mar. 19, 1965) and in figure 34 . The steepening of hydraulic gradient may reflect low gross transmissibility of the Tertiary rocks, coupled with a thinning of the valley-fill aquifer.

Thus, available evidence indicates that the Tertiary rocks northeast and southwest of the spring line are the hydrogeologic equivalents of the tuff aquitard beneath Nevada Test Site. Tertiary tuffs equivalent to the bedded-tuff and the welded-tuff aquifers are apparently absent in the discharge area.

Data from seven wells in Tps. 17-18 S., R. 50 E., suggest that permeability of the valley-fill aquifer immediately southwest of the spring line is also generally low. The specific capacity of these wells ranges from 0.4 to $10 \mathrm{gpm}$ per foot of drawdown and has a median value of $0.5 \mathrm{gpm}$ per foot of drawdown (R. H. Johnston, written commun., Mar. 1967). These wells penetrate about 450 to 840 feet of saturated valley fill. Lithologic logs based on cuttings (furnished by Messrs. E. L. Reed and Chester Skrabacz) indicate that the bulk of the valleyfill deposits at these well sites are lake beds. The water tapped by the wells probably comes principally from discontinuous gravel lenses interbedded with the lake beds.

\section{GROUND-WATER DISCHARGE}

Ground water discharges from the Ash Meadows area in east-central Amargosa Desert through springs, evapotranspiration, and underflow. The average spring discharge amounts to about 17,100 acre-feet annually. (about 10,600 gpm). The underflow and the evapotranspiration cannot be readily estimated.

CHARACTER AND GEOLOGIC CONTROL OF SPRING DISCHARGE

Thirty springs lie along a line trending N. $20^{\circ}-25^{\circ} \mathrm{W}$. that extends from the north end of Resting Springs Range to lat $36^{\circ} 30^{\prime} \mathrm{N}$., a distance of about 10 miles (fig. 34). A polygon enclosing the springs would be about half a mile wide on its north end and about $3 \frac{1 / 3}{\text { miles wide }}$ at the south end; 20 of the springs lie within a rectangle 10 miles long by 1 mile wide. The spring lineament closely parallels the trend of the ridges that border most of the springs on the east. The altitude of the springs ranges from about 2,200 to 2,345 feet, with the highest orifices closest to the ridges of Paleozoic carbonate rock (Bonanza King Formation). The highest water level in the discharge area $(2,359 \mathrm{ft}$ above sea level) is that of the pool in Devils Hole, a cavern in the Bonanza King Formation near the center of the spring line (fig. 34).

The springs are generally of similar geologic setting and shape and are variously referred to as pool springs, tubular springs, or ojos de agua (eyes of water). All but one of the springs (a minor spring at Point of Rocks) emerge from relatively flat-lying Pleistocene(?) lake beds (clays and marls) and local travertine deposits. At the surface the spring pools have a roughly circular outline and generally range from a few feet to 30 feet in diameter (frontispiece). Some of the springs are 15 or more feet deep. The pools narrow irregularly with depth to relatively small orifices a fraction of the pool's surface diameter. Some orifices extend vertically downward, whereas others trend diagonally downward from the bottom of the pool. Where the walls of the pools are clearly visible to depths of several feet, lake beds and travertine are the only rock types exposed; no permeable gravel beds are visible. Lips, overhanging ledges composed of lake sediments or of travertine, are common on the deepest side of the pool (frontispiece). The water moving up toward the surface of the pools is usually crystal clear but carries fine silt in suspension. Reflection of light by the silt particles gives the water a boiling appearance, an aid in spotting the narrow orifices at the bottom of some pools.

The spring discharge area is overgrown with a variety of phreatophytes: copper rush (Juncus cooperi), saltgrass (Distichlis spicata), saltbush (Atriplex canescens), saltcedar (Tamarisk gallica), arrow weed (Pluchea sericea), fat-hen saltbush (Atriplex hastata), 


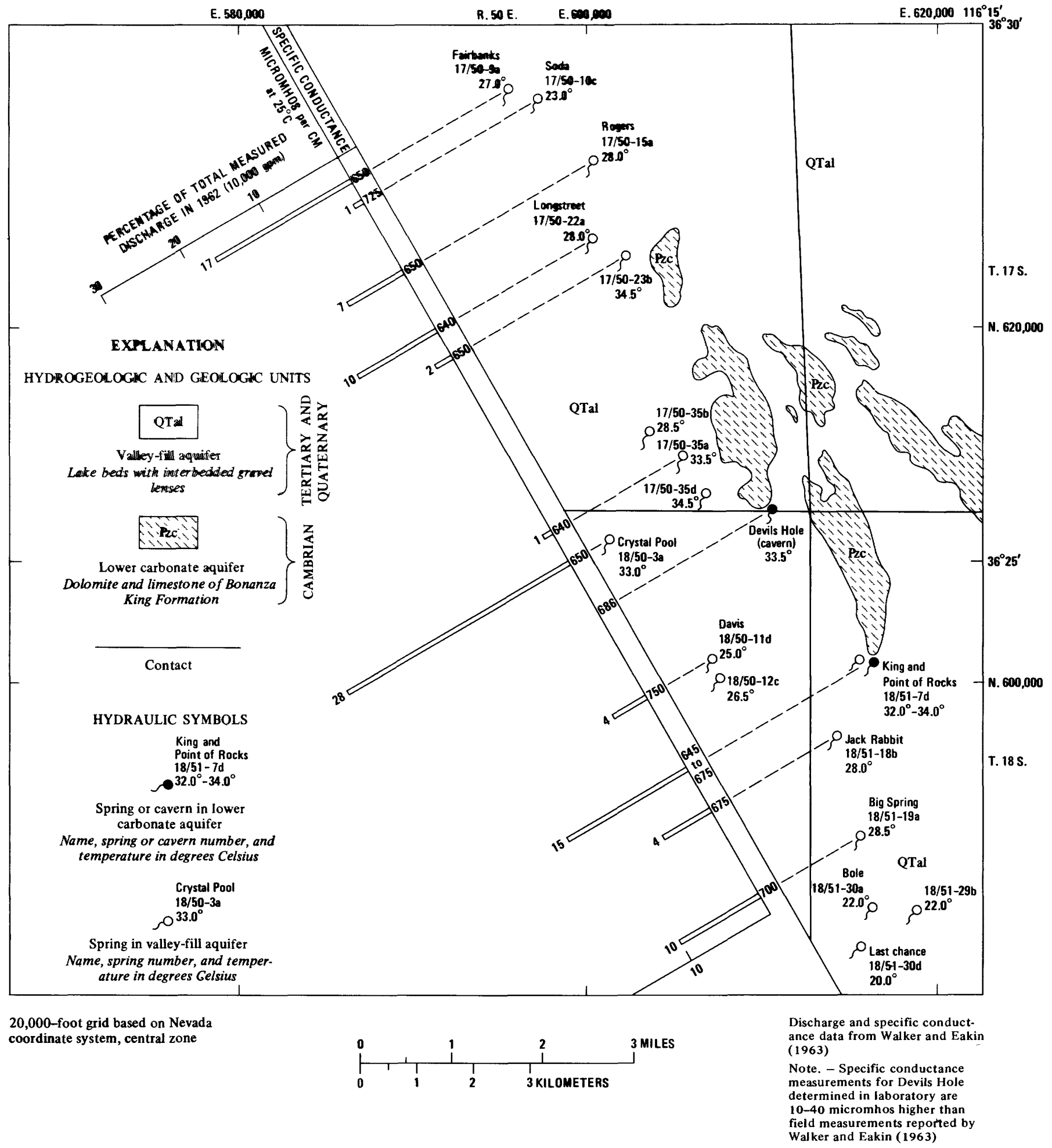

FIGURE 35. - Major springs at Ash Meadows; interrelationships among discharge, specific conductance, temperature and outcrops of the lower carbonate aquifer.

Torrey seepweed (Suaeda torreyana), and mesquite $/$ spring discharges less than $20 \mathrm{gpm}$ and is the only one (Prosopis sp.). emerging directly from the lower carbonate aquifer in

One of a group of springs at Point of Rocks (fig. 34) the Ash Meadows discharge area. However, ground emerges directly from the lower carbonate aquifer. This $\mid$ water also occurs in the lower carbonate aquifer in Devils 
Hole, where the water table is about 50 feet below land surface; this cavern is described in the section "Lower Carbonate Aquifer."

Discharge, water temperature, and specific conductance of 11 of the highest hielding springs and water temperature of 6 minor springs are summarized in figure 35 . The total measured discharge of 24 springs discharging more than $1 \mathrm{gpm}$ was about $10,300 \mathrm{gpm}$ (about 16,600 acre-ft annually) in the summer of 1962 (Walker and Eakin, 1963, table 8). The distribution of discharge along the 10-mile spring line is greatest near the center of the line (at Crystal Pool), but it is otherwise surprisingly uniform.

Discharge measurements presented by Walker and Eakin (1963) for a few of the 11 major springs extend back to 1910. These measurements show a substantial decrease in the discharge at some springs but no significant decrease at others. No firm conclusions can be drawn from the apparent variation in discharge because of the uncertain accuracy of the older measurements and possible variations in discharge caused by alteration of the spring orifices by man. However, the similarity of the discharge measurements at several springs suggests that there has been no significant variation in total discharge since the turn of the century. Measurements at $17 \mathrm{com}$ mon springs in 1953 and 1962 suggest no significant change in discharge in this period of time. This conclusion is supported by measurements of water-level fluctuation in Devils Hole between 1945 and 1960. These measurements indicate that changes in water level of the pool are short term and due only to changes in barometric pressure, earthquakes, and earth tides (O. J. Loeltz, written commun., 1960); measurements made between 1963 and 1967 substantiate Loeltz's evaluation.

TABLE 7. - Spring discharge at Ash Meadows in 1953 and 1962 [Data from Walker and Eakin (1963)]

\begin{tabular}{cccc}
\hline $\begin{array}{c}\text { Number of } \\
\text { springs } \\
\text { measured }\end{array}$ & Month and year & $\begin{array}{c}\text { Total } \\
\text { discharge } \\
\text { (gpm) }\end{array}$ & $\begin{array}{c}\text { Total annual } \\
\text { discharge } \\
\text { (acre-ft per yr }\end{array}$ \\
\hline 17 & Jan. and Feb. 1953 & 10,900 & 17,600 \\
17 & July 1962 & 10,300 & 16,600 \\
\hline
\end{tabular}

Head gradients, temperature of water, and chemical quality of water suggest that water emerging from the pool springs is derived 'y upward leakage from the lower carbonate aquifer, which flanks and underlies the Quaternary strata at the spring line.

The potentiometric surface in the carbonate aquifer at Devils Hole is 14 to 159 feet higher than the orifice altitudes at the spring pools (fig. 34). Thus a positive head gradient exists for moving water upward from the carbonate aquifer into the overlying sedimentary deposits and to the land surface, provided an avenue of permeability is available. The possible nature of the flow path is discussed elsewhere in this chapter.

A comparison of water temperature in the lower car- bonate aquifer, at the spring pools, and in the Quaternary strata suggests that the springs are fed by the carbonate aquifer. The water temperature in Devils Hole and at Point of Rocks Springs (where water discharges directly from the carbonate aquifer) ranges from $33.5^{\circ}$ to $34.0^{\circ} \mathrm{C}$ (fig. 35). The temperature of water from springs whose discharge exceeds $1,000 \mathrm{gpm}$ ranges from $27.0^{\circ}$ to $33.0^{\circ} \mathrm{C}$; water temperature of lower yield springs varies from $23.0^{\circ}$ to $34.5^{\circ} \mathrm{C}$. These temperatures are $4.5^{\circ}$ to $16.0^{\circ} \mathrm{C}$ higher than the mean annual air temperature at Lathrop Wells $\left(18.5^{\circ} \mathrm{C}\right)$. Periodic temperature measurements reported by Walker and Eakin (1963, table 8) and Miller (1948, table 41) and made by the senior author indicate no seasonal or long-term variation (since 1930) in water temperature at the major springs. In contrast to the temperatures of the springs, temperatures of water from deep wells tapping the valley-fill deposits at, and west of, the spring line range from $19.5^{\circ}$ to $28.5^{\circ} \mathrm{C}$ but are usually less than $24.5^{\circ} \mathrm{C}$. These data suggest, in a general way, that the spring discharge, though emerging from Quaternary lake beds, is fed by direct leakage from the lower carbonate aquifer.

Areal variations of spring-water temperatures at Ash Meadows offer further evidence that the pool springs are fed by the carbonate aquifer. Springs within a half mile of the carbonate-rock ridges that border the discharge area on the northeast (fig. 35) have water temperatures above $32.0^{\circ} \mathrm{C}$, regardless of their discharge rate, whereas springs at greater distances from the ridges have water temperatures that are generally lower than $32.0^{\circ} \mathrm{C}$ and that appear to be related to discharge rate (compare, for example, Fairbanks and Soda Springs). This pattern is explainable as follows. Water in the carbonate aquifer, as mentioned above, is $33.5^{\circ}$ to $34.0^{\circ} \mathrm{C}$, and the mean annual temperature in the region is about $18.5^{\circ} \mathrm{C}$. Water in the upper several hundred feet of the valley fill at Ash Meadows, on the other hand, is about $19.5^{\circ} \mathrm{C}$, as indicated by temperature of water flowing from wells 17/50-15a1 and 17/50-29d1 (fig. 34); these wells are respectively 464 and 471 feet deep (Walker and Eakin, 1963, table 3). Thus, a temperature gradient is present for transporting heat from the carbonate rocks to the land surface. Near the carbonate-rock ridges, where the buried carbonate aquifer is shallowest, water moving to the surface along a funnel or fault zone (see below) has little time to come into temperature equilibrium with the cooler surrounding Quaternary and Tertiary sediments; here, even springs with discharges as low as $100 \mathrm{gpm}$ have water temperatures as high as $33.5^{\circ} \mathrm{C}$. However, at greater distances from the ridges (where the aquifer is buried at depths of hundreds to probably more than $1,000 \mathrm{ft}$ ), the traveltime of water from the carbonate aquifer to the surface is generally longer, permitting greater loss of heat to the surrounding sediments. Furthermore, if depth to the aquifer at adjacent springs 
is equal, the spring with the higher discharge should reach the surface at a higher temperature because the heat content of the springs is directly proportional to discharge, but the heat-dissipation rate in the surrounding sediments is roughly independent of discharge.

The specific conductance of water from 11 major springs (discharge about $100 \mathrm{gpm}$ or more) emerging from the lake beds ranges from 640 to 750 micromhos per $\mathrm{cm}$ at $25^{\circ} \mathrm{C}$ (fig. 35); the specific conductance of water from 8 of these springs ranges from 640 to 675 microm hos per $\mathrm{cm}$ at $25^{\circ} \mathrm{C}$. The specific conductance of water from Devils Hole and Point of Rocks Springs ranges from 645 to 686 micromhos per $\mathrm{cm}$ at $25^{\circ} \mathrm{C}$. By contrast, the specific conductance of water from wells tapping the valley-fill aquifer in the central Amargosa Desert generally ranges from 300 to more than 1,000 micromhos per $\mathrm{cm}$ at $25^{\circ} \mathrm{C}$ (Walker and Eakin, 1963, tables 3 and 9). The consistent similarity between the specific conductance of the ground water from the pool springs and that of water in the lower carbonate aquifer is a third indication that the springs are fed by upward leakage from the flanking and underlying lower carbonate aquifer. Complete chemical analyses of these waters, discussed in another chapter, also support this conclusion.

In summary, head differentials, water temperature, and water chemistry all indicate that water emerging from the spring pools (developed in the Quaternary strata) originates from the underlying and flanking lower carbonate aquifer. Two questions now merit brief examination. First, what geomorphic or structural feature(s) is responsible for forcing water in the carbonate aquifer to the surface at Ash Meadows? Second, how were the orifices developed in the relatively impermeable lake beds and other Cenozoic sediments, and what is their character at depth?

The spring line could be caused by topographic, stratigraphic, or structural geologic factors, or by a combination of factors. The spring line might simply be attributed to an intersection of the water table in the lower carbonate aquifer and the land surface. However, the lower carbonate aquifer crops out in the southwestern and southern parts of the Amargosa Desert (NW1/4 sec. 35, T. 27 N., R. 4 E.) and at the north end of Eagle Mountain (SE $1 / 4$ sec. 7 and SW $1 / 4$ sec. 8, T. 24 N., R. 6 E.) at altitudes as much as 120 to 160 feet lower than the water level in Devils Hole. If the topographic setting is a factor controlling the spring line - that is, the carbonate reservoir is brimful and overflows near Ash Meadows then spring discharge should also occur near the topographically lower outcrops of the lower carbonate aquifer; no such discharge occurs. Moreover, topography does not explain the large pool springs, such as Fairbanks Spring, Crystal Pool, and Big Spring, which emerge from lake sediments at distances of as much as 2 miles from outcrops of the lower carbonate aquifer.
Several factors suggesting that the spring line is fault controlled follow:

1. Linearity of the spring line for a distance of 10 miles.

2. Recent(?) faults that cut the lake beds parallel the spring line and lie immediately west of several springs.

3. Parallelism between the spring line and the strike of both bedding and the faults cutting the carbonate bedrock.

4. A major displacement in the pre-Tertiary rocks - the inferred gravity fault (pl. 1) - parallels and nearly coincides with the spring line (D. L. Healey and C. H. Miller, written commun., Mar. 1965).

More than a single fault zone may control the spring discharge. The inferred gravity fault (shown as an hydraulic barrier in figure 34 ) lies as much as a mile southwest of a line connecting Fairbanks, Rogers, Longstreet, and Point of Rocks Springs, and it may serve as the barrier for these springs (fig. 34). However, Crystal Pool and Big Spring, which together contribute about 40 percent of the measured discharge of the line of springs, are as much as 1 mile west of the inferred gravity fault and are over lows on the gravity map beneath which the pre-Tertiary rocks are probably buried several thousand feet (D. L. Healey and C. H. Miller, written commun., Mar. 1965). One or more other faults may be needed to explain these springs, although the springs could be fed by eastward dipping funnels (see discussion below) originating east of the gravity fault.

Several hypotheses may explain the geological character of the fault-controlled hydraulic barrier(s). The simplest hypothesis is that the lower carbonate aquifer, cropping out in the ridges east of the spring line, is completely or partially dammed by downfaulted Tertiary and Quaternary aquitards. R. L. Christiansen (oral commun., Mar. 1966) suggested this hypothesis to the authors. Christiansen's hypothesis is strengthened by consideration of the stratigraphic position of the carbonate rocks composing the ridges immediately east of the spring line. These ridges consist of the Bonanza King Formation (Middle Cambrian age), which, except for several hundred feet of carbonate rocks at the top of the Carrara Formation, constitutes the oldest and stratigraphically the lowest formation within the lower carbonate aquifer (table 1). Thus, downfaulting of the relatively impermeable Cenozoic rocks, which may aggregate more than 3,000 feet, against the lower carbonate aquifer and the underlying lower clastic aquitard could effectively seal the lower carbonate aquifer and force the water to discharge from it east of the fault zone. The gravity map indicates that the pre-Tertiary surface is downdropped 2,000 to several thousand feet (along the inferred gravity fault) immediately west of a line connecting Longstreet and Point of Rocks Springs. Thus, partial juxtaposition of the Tertiary rocks and the lower 
clastic aquitard is possible with attendant damming of the lower carbonate aquifer. The presence of Tertiary rocks in discontinuous northwest-trending outcrops between Ash Tree Spring and Grapevine Springs (fig. 34) does not preclude them at depth beneath the spring line, because a northwest-trending gravity low occurs between the two trends.

Normal faulting may satisfactorily explain the geologic control of the springs in the southern half of the spring line, but it may not offer adequate explanation for the springs northwest of Longstreet Spring. Geologic mapping indicates that the buried lower carbonate aquifer is probably much thicker east of Fairbanks, Longstreet, and Rogers Springs than south of Longstreet Spring (Denny and Drewes, 1965, and R. H. Moench, written commun., Mar. 1965). In addition, the displacement on the inferred gravity fault decreases northward; near Crystal Pool the displacement of several thousand feet is indicated by the gravity survey, whereas at the northwest end of the spring line the displacement may amount to only 1,000 to 2,000 feet. Accordingly, although juxtaposition of the Tertiary and Quaternary aquitards against the lower carbonate aquifer could markedly reduce the cross-sectional area of flow through the carbonate rocks, complete blockage of the aquifer in this area is less likely unless the fault zone itself is relatively impermeable. Thus, some ground water in the lower carbonate aquifer (northwest of Longstreet Spring) might move directly into the central Amargosa Desert without being forced upward into the Quaternary and Tertiary valley fill.

A second hypothesis to explain the spring line requires curtailment of the lower carbonate aquifer through either (1) fault juxtaposition of the aquifer and the lower clastic aquitard or (2) folding of the clastic aquitard into a structurally high position. The bulk of the northnorthwest trending Resting Springs Range consists of the lower clastic aquitard, specifically rocks of the Wood Canyon Formation and the Stirling Quartzite (fig. 34). At the north end of the Resting Springs Range the lower clastic aquitard is overlain by Tertiary clastic rocks that trend northwestward to Ash Tree Spring, a distance of about 12 miles from the northernmost outcrop of the lower clastic aquitard in the range (fig. 34). The Tertiary outcrops indicate that the pre-Tertiary rocks are close to the surface in this area, and the gravity map suggests that they may be buried at depths as shallow as 2,000 feet below the surface just west of the spring line (D. L. Healey and C. H. Miller, written commun., Mar. 1965). If the Tertiary rocks'west of the spring line are underlain principally by the lower clastic aquitard, as they are at the north end of the Resting Springs Range, the lower clastic aquitard could serve as a principal or secondary hydraulic barrier responsible for the spring line. The areal dispositions of the lower clastic aquitard and the lower carbonate aquifer could presumably have been set during pre-Tertiary deformation, and subsequent Tertiary block faulting would have created the gravity anomaly reported by Messrs. Healey and Miller (written commun., Mar. 1965).

A third hypothesis involves a major strike-slip fault zone mapped in Stewart Valley by R. L. Christiansen, R. H. Moench, and M. W. Reynolds (written commun., 1964) and shown on plate 1 (structural feature 17). This postulated major fault zone trends almost parallel to the spring line. If the strike-slip fault zone continues in the subsurface northwestward beyond Stewart Valley, the mapped area, it might create the hydraulic barrier described either by virtue of gouge developed along it or through juxtaposition of Paleozoic carbonate and clastic rocks.

The authors favor the idea that the ground-water barrier is caused by normal faulting of the poorly permeable Cenozoic rocks against the lower carbonate aquifer. Of course, a combination of two or all three of the hypotheses may explain the hydraulic barrier. On plate $1\left(\sec . A-A^{\prime}\right)$, the barrier is diagrammatically shown as a combination of the first and second hypothesis.

Granting that the spring line is structurally controlled and that the spring water originates within the lower carbonate aquifer, how does the water move upward through the relatively impermeable Cenozoic strata to become concentrated in the funnel-shaped spring pools? If the hydraulic barrier(s) is caused principally by preTertiary structural curtailment of the lower carbonate aquifer, then it is possible that the major springs may reflect the approximate position of pre-Tertiary springs, some of which, owing to hydrostatic head, continued to flow during deposition of both the Tertiary and Quaternary sediments. If this occurred, each spring is probably fed by a sand- and silt-filled funnel which extends irregularly downward to the lower carbonate aquifer and which is surrounded by generally impermeable Cenozoic strata. Some leakage from the postulated funnels to the gravel lenses within the Cenozoic sequence probably occurs, but the rate of such leakage is retarded by the probable discontinuous nature of these lenses. If the spring line was created in middle to late Tertiary time by fault juxtaposition of the Tertiary aquitard against the lower carbonate aquifer, then the position of the orifices may be controlled in part by fault zones, most of which have since been obscured by deposition of the youngest Quaternary lake deposits. Hydrostatic head, again, might have enabled major springs to maintain themselves by piping during deposition of the Quaternary lake and other valley-fill deposits.

Evidence that a major spring once discharged from Devils Hole follows. Devils Hole, with a reported minimum depth of 365 feet, is about 70 feet long and 30 to 40 feet wide; at the water surface, 50 feet below land 
surface, the pool is about 40 feet long and 10 feet wide (Worts, 1963). Although the water level in Devils Hole has probably been constant for the last 15 and possibly 50 years, several bits of evidence indicate that it fluctuated widely in the geologic past and that a large spring once emerged from the hole. Water-level fluctuations of possibly as much as 20 feet are recorded on the walls of the sink itself. Figures 36 and 37, photographs taken in the sinkhole, show former stands of the water.

Geologic and zoological evidence suggests that the water level in Devils Hole was once at the surface. Denny and Drewes (1965, p. L30-L31) reported a lobate sheet of spring deposits adjacent to Devils Hole. They stated:

Just west of Devils Hole a sheet of spring deposits *** measures roughly 500 by 1,500 feet and mantles ridges and shallow gullies. The edge of the sheet is lobate and the fingers point downwash. The deposits are at least 2 feet thick, thinning to a few inches near their borders; on the ridges they overlie a desert pavement. An east-trending narrow band of slightly more massive deposits suggests seepage along a fissure. The sheet is draped over the landscape and is perhaps the relic of a wet meadow which surrounded a flowing spring.

Fish in Devils Hole and in major spring pools (Miller, 1946, 1948; Hubbs and Miller, 1948) provide possible zoological evidence for interconnected pluvial lakes in

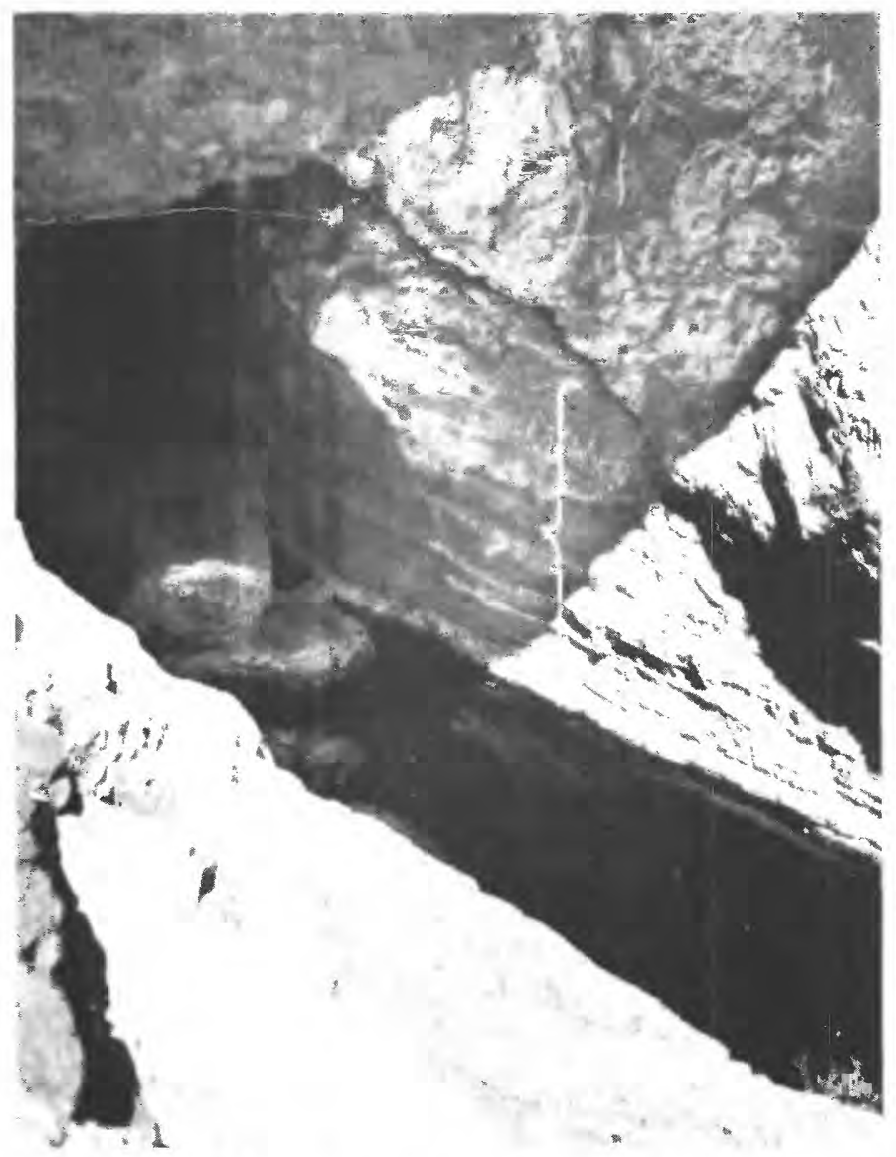

Figure 36. - Solution notches (bracket) marking water levels as much as 4 feet above 1966 water level of pool at Devils Hole.

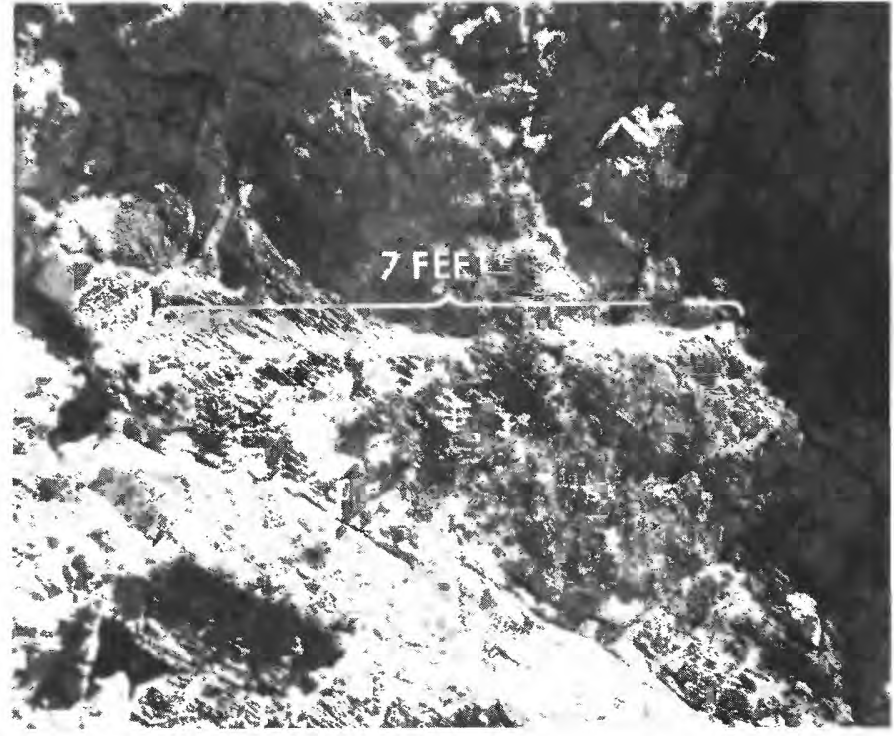

Figure 37. - Possible former stand of water (horizontal line in middle ground) about 20 feet above 1966 water level on south wall of Devils Hole. Bonanza King Formation dips $45^{\circ}$ to the right, or west.

both Amargosa Desert and Death Valley. The small fish (Cyprinodon) presumably survived the dessication of lakes at the end of the last pluvial period by adapting to living in the spring pools. Presumably with decline of the water level, some of the fish population retreated into the depth of Devils Hole, where they live today.

Eleven of 30 springs discharge more than 98 percent of the water at Ash Meadows, and 5 of them (Fairbanks, Longstreet, Crystal Pool, King, and Big Springs) discharge about 80 percent of all the water at Ash Meadows (fig. 35). When considered together with the preceding discussion of Devils Hole, these large discharges from five widely spaced springs may be evidence that all the major pool springs originate as flow concentrated by caverns developed within the lower carbonate aquifer. If cavernous control were lacking, the spring line might be more continuous, and the discharge from individual springs would be much smaller. However, hydraulic tests of the lower carbonate aquifer indicate that fracture transmissibility of the aquifer can be as great as 900,000 gpd per ft and that the transmissibility is highly variable from well to well or at depth within a single bore. Therefore, the pool springs might also originate from highly fractured and transmissive areas within the lower carbonate aquifer as well as from caverns. For example, a block of highly fractured carbonate rock even as small as $40 \times 40 \times 40$ feet could serve as a highly efficient natural infiltration gallery capable of discharging hundreds of gallons per minute under small head differentials; solution caverns need not be invoked as the sole source of the high-yield pool springs. The authors favor solution-cavity control of the discharge pattern. 
UPWARD LEAKAGE FROM LOWER CARBONATE AQUIFER BENEATH VALLEY NORTHEAST OF SPRING LINE

Discharge from the lower carbonate aquifer is upward into the Cenozoic rocks underlying the unnamed alluvial valley and playa northeast of the spring line (fig. 34 ).

Stands of mesquite and other phreatophytes fringing the east side of the playa (pl. 1) indicate a shallow water table in the vicinity of the playa. The fluffy texture of surface materials underlying parts of the playa and the high moisture content of the sediments within a foot or two of the surface are additional indications of a shallow water table. In the southwestern corner of the playa, several small pits excavated during mining of clay intersect the water table. The altitude of the floor of the playa is 2,331 feet above mean sea level, or about 30 feet lower than the head within the lower carbonate aquifer at Devils Hole and at well 65-62 north of the playa. With this head differential, some upward leakage of water from the lower carbonate aquifer into the Quaternary and Tertiary rocks is certain.

Altitude of the water level in wells $16 / 51-28 \mathrm{~d} 1$, $16 / 51-36 \mathrm{a} 1$, and $17 / 51-1 \mathrm{a} 1$, which tap the valley-fill aquifer, indicate that some leakage also is probably upward in areas beyond the playa; these levels are 17 to 61 feet lower than the head in well 65-62, which taps the lower carbonate aquifer.

The quantity of upward leakage from the lower carbonate aquifer into the Cenozoic rocks is difficult to estimate. In Yucca Flat an estimate of downward leakage could be made because, owing to the deep water table, virtually all the crossflow had to move through the tuff aquitard. However, in the unnamed valley the water table ranges from 454 feet below the surface at well 65-66 to a few tens of feet below the surface near the playa (fig. $34)$. Because of the shallow water table, the valley-fill aquifer and the lower carbonate aquifer may locally be in direct contact where the carbonate aquifer forms shallow buried ridges if the relatively impermeable Tertiary strata are absent (owing to nondeposition or erosion). Conversely, beneath the structurally deepest parts of the valley, crossflow between aquifers would be greatly retarded (as in Yucca Flat) by the probable thick section of Tertiary strata between the lower carbonate aquifer and the valley fill. By analogy with Yucca Flat, where the leakage probably amounts to less than 100 acre-feet annually, the upward leakage in this area is believed to be less than 1,000 acre-feet annually because of the low gross transmissibility of both the basal valley fill and the Tertiary rocks.

The upward leakage into the valley-fill aquifer may leave the valley in two ways. The principal ground-water flow is probably toward the playa to replenish the discharge by evapotranspiration. Some water may flow westward toward the main part of the Amargosa Desert through the area between Longstreet Spring and the hills of carbonate rock in sec. 28, T. 16 S., R. 50 E. Such flow is probably retarded by (1) the low permeability of the valley fill between Longstreet and Fairbanks Springs and (2) possible upward leakage from carbonate rocks buried at relatively shallow depths between Fairbanks Spring and the hills north of the springs.

\section{ESTIMATES OF EVAPOTRANSPIRATION}

Ground water is also discharged from the region by evaporation from playa surfaces and through transpiration by phreatophytes. The major areas of evapotranspiration are shown on plate 1. Estimates of evapotranspiration made by Walker and Eakin (1963, p. 21-24, and table 7) suggest that the water discharged by phreatophytes at Ash Meadows may be derived entirely from recycled spring discharge. They estimated a total evapotranspiration in the Amargosa Desert of about 24,000 acre-feet annually, 10,500 acre-feet of which occurs at Ash Meadows; the remainder represents discharge from playa surfaces, chiefly Alkali Flat (southeast of Death Valley Junction; pl. 1 and fig. 34), and an area of very shallow water table (1-3 ft) extending several miles north and northeast of this playa. Nevertheless, the possibility that some of the phreatophytes at Ash Meadows are fed by water which has leaked up from the carbonate aquifer, rather than by recycled spring discharge, cannot be dismissed until a detailed study of evapotranspiration and the spring runoff regimen is made. Until such a study is done, the spring discharge (about 17,000 acre-ft annually) is considered the most accurate available measure of discharge from the lower carbonate aquifer at Ash Meadows.

POSSIBLE UPWARD LEAKAGE SOUTH OF LATHROP WELLS

Upward flow from pre-Tertiary rocks into the valleyfill aquifer may also occur along a 10-mile strip between Lathrop Wells and well 16/49-26d1 (fig. 34). The configuration of potentiometric contours for the valley-fill aquifer in this area suggests a hydraulic discontinuity that parallels the inferred gravity fault (fig. 34 ). The discontinuity, indicated by apparent change in direction of ground-water flow and the steepening of hydraulic gradient, may reflect upward crossflow.

The geologic map and the sections of R. L. Christiansen, R. H. Moench and M. W. Reynolds (written commun., Mar. 1965) suggest that pre-Tertiary rocks within the zone of saturation between the inferred gravity fault on the west, the Specter Range thrust on the south, and the northern one-third of the Specter Range on the east (fig. 34) consist principally of lower clastic aquitard overlain locally at shallow depth by the lowest part of the lower carbonate aquifer; these rocks form the bulk of the upper plate of the Specter Range thrust fault (pl. 1 and fig. 34). Their interpretation that 
the lower carbonate aquifer is underlain by the clastic aquitard at shallow depth is supported by data for well $68-60$, where the water table is 674 feet below land surface. Well 68-60 penetrated the lower carbonate aquifer in the interval 160 to 400 feet and the lower clastic aquitard in the interval 400 to 910 feet.

The inferred gravity fault affects the distribution of the pre-Tertiary rocks. At a point about 1 mile east of Lathrop Wells, the gravity survey suggests a displacement (downthrown on the west) of the Tertiary-preTertiary surface of 500 to 1,500 feet (D. L. Healey and C. H. Miller, written commun., Mar. 1965). At a point about 1 mile southeast of the intersection of the inferred gravity fault with the trace of the Specter Range thrust, the displacement is about 1,200 to 2,200 feet.

The configuration of the potentiometric contours for the valley-fill aquifer probably reflects westward drainage of a ground-water ridge possibly formed by upward leakage along one or more fault zones paralleling and including the inferred gravity fault (fig. 34) and drainage of poorly permeable valley fill toward more transmissible valley fill west of the fault zone. These possibilities are supported by analogy with hydrologic conditions along the inferred gravity fault adjacent to the spring line and by drillers' log of wells 16/49-14al and 16/49-23a1 (Walker and Eakin, 1963); these logs indicate that the valley fill tapped by these wells is composed chiefly of clay.

The quantity of upward leakage in this area is probably small, because such leakage probably originates principally from the lower clastic aquitard.

\section{MAGNITUDE OF POSSIBLE UNDERFLOW ACROSS THE DISCHARGE AREA}

In addition to discharge at the spring line (about 17,000 acre-ft per yr), discharge through upward leakage within the unnamed valley northeast of the spring line (1,000 acre-ft per yr, estimated), and possible minor discharge along the inferred gravity fault south of Lathrop Wells, some ground water probably also moves southwestward across the Ash Meadows discharge area through the lower carbonate aquifer. Between Longstreet Spring and the southwest corner of T. $16 \mathrm{~S}$., R. $50 \mathrm{E}$., the carbonate aquifer may be imcompletely blocked by Tertiary aquitards, and some underflow may move westward through the lower carbonate aquifer and Cenozoic aquitards. (See section "Character and Geologic Control of Spring Discharge.")

The magnitude of the hypothesized underflow across the spring line into the central Amargosa Desert cannot be approximated despite the availability of crude estimates of discharge from central and southern Amargosa Desert. Ground water can leave central and southern Amargosa Desert either by underflow and evaporation in the vicinity of Eagle Mountain (fig. 34) at the south end of the valley or by underflow through the lower carbonate aquifer toward Death Valley. Walker and Eakin (1963, p. 22) estimated underflow toward the south to be about 500 acre-feet annually. The evaporation from Alkali Flat and vicinity north of Eagle Mountain may amount to more than 10,000 acre-feet annually. Westward movement of ground water from the Amargosa Desert to the Furnace Creek area in Death Valley was suggested by Hunt and Robinson (1960) and by Hunt, Robinson, Bowles, and Washburn (1966) on the basis of a similarity of the chemistry of spring water in both areas; they further hypothesized that ground-water flow between the two areas is through fault zones. The total discharge from the Furnace Creek area, about 30 miles west of Devils Hole, is reported to be $3,150 \mathrm{gpm}$ (Hunt and others, 1966, table 25), or about 5,100 acrefeet annually.

The regional potentiometric map (pl. 1) and water chemistry (pl. 3) show that the ground water in central and southern Amargosa Desert is derived from three sources: (1) possible underflow across the spring line plus recycled spring discharge, (2) flow from Jackass Flats, and (3) flow from northwestern Amargosa Desert. Thus, until the magnitude of the contribution from each of these sources is known, as well as the head relationships between the lower carbonate and the valley-fill aquifers in central and southern Amargosa Desert, no reliable estimate of underflow across the spring line at Ash Meadows is possible, even were precise data on discharge in and underflow out of the central and the southern Amargosa Desert available.

In summary, in view of possible underflow beneath the spring line, the measured spring discharge of about 17,000 acre-feet annually must be considered the minimum quantity of ground water in transit through the lower carbonate aquifer at Ash Meadows.

\section{AREAL EXTENT OF THE GROUND-WATER BASIN}

Definition of the hydrologic boundary of the Ash Meadows ground-water basin is greatly hindered by the complexity of the geologic structure, the limited potentiometric data, and, most critically, the interbasin movement of ground water through the thick and areally extensive lower carbonate aquifer. Interbasin movement precludes straightforward use of topographic and isohyetal maps to pinpoint possible hydrologic divides. An estimate of the minimum area of the Ash Meadows ground-water basin, based on isohyetal, potentiometric, and geologic evidence discussed below, is shown on plate 1. The boundary should be considered a first approximation at best.

\section{INFERRED FROM ISOHYETAL MAP}

In a region of known or inferred interbasin movement of ground water, use of an isohyetal map to estimate the 
boundaries of a basin is severely limited. Yet, certain patterns evident on the isohyetal map of the study area. (fig. 3) may provide clues for at least a part of the boundary of the Ash Meadows ground-water basin. The mean annual precipitation in Amargosa Desert, Yucca Flat, Frenchman Flat, Jackass Flats, Indian Springs Valley (except the southernmost part), and Three Lakes Valley (except the southernmost part) ranges from 3 to 8 inches. On the Spring Mountains and the Sheep Range the mean annual precipitation generally ranges from 10 to 25 inches; and on the Belted, Timpahute, and Pahranagat Ranges it ranges from 10 to 14 inches. This distribution of precipitation suggests that the Spring Mountains and the Sheep Range may form the southern and eastern border of the Ash Meadows ground-water basin and that the Belted, Timpahute, and Pahranagat Ranges may form the northwestern, northern, and northeastern borders. On the southwest, specifically in the area between the south end of Shoshone Mountain and the northwest end of the Spring Mountains, the mean annual precipitation amounts to about 6 inches. Thus, the isohyetal map suggests that the regional drainage of ground water is toward Ash Meadows and that possibly eight intermontane valleys - Three Lakes, Desert, Indian Springs, Emigrant, and Mercury Valleys and Yucca, Frenchman, and Jackass Flats - might be tributary to the discharge area.

Two important considerations limit use of the isohyetal map: (1) areal variations in rock type and soil cover, and (2) interbasin movement of water. For example, less infiltration may occur in welded-tuff than in carbonate-rock terrane because of the greater density and solution alteration of fractures in the carbonate rocks and because of clayey soil developed on the tuff. Thus, as much or more recharge may result from 6 inches of annual precipitation on the fractured carbonate rock of the Spotted Range than from 12 inches on the welded tuffs capping the highest parts of the Belted Range.

If recharge could somehow be accurately estimated from the isohyetal map, taking differences of rock type, soil development, precipitation type, and slope into account, the map would still not serve as a positive indicator of the hydrologic boundary of the Ash Meadows ground-water basin. Near the margin of a ground-water basin, recharge of as little as a few tenths of an inch of water annually to the principal aquifer influences the position of the ground-water divide in that aquifer. However, the addition of several times this recharge near the center of the system, where the volume of ground water in transit may be several hundred times the recharge cited, may do no more than create a minor mound in the potentiometric surface; such a mound need not significantly affect regional flow patterns in thick aquifers (Tóth, 1963). Thus, the possibility of a shallow ground-water mound beneath a ridge of carbonate rock receiving relatively moderate precipitation - for example, the northern Spotted Range (8 to 9 in.) or the Pahranagat Range (10 to 12 in.) - cannot be cited as proof that the mound forms a hydrologic boundary of the basin even should the quantity of recharge and the position of the mound within the basin be known.

Despite these qualifications, the isohyetal map suggests that the Spring Mountains and the southern half of the Sheep Range - the highest ranges in southern Nevada - could serve as the southern and the eastern hydrologic boundaries of the Ash Meadows basin. The highest parts of both ranges are composed chiefly of the lower carbonate aquifer, which should be conducive to maximum infiltration. If these ranges mark the approximate southern and eastern boundaries of the basin, then both Three Lakes and Indian Springs Valleys are probably within the Ash Meadows ground-water basin.

Use of the isohyetal map (fig. 3) as an indicator of the basin boundary may also be justifiable for areas of relatively low precipitation (10 to $16 \mathrm{in}$.), such as the northwestern Spring Mountains, which are underlain chiefly by the lower clastic aquitard. But, use of this map to establish hydrologic divides in areas of similar precipitation that are underlain by the lower carbonate aquifer is risky.

\section{INFERRED FROM POTENTIOMETRIC MAP}

The regional potentiometric map (pl. 1) indicates that most or all of Yucca Flat, Frenchman Flat, eastern Jackass Flats, southern Indian Springs Valley (south of U.S. Highway 95), Mercury Valley, and the unnamed valley northeast of the spring line in east-central Amargosa Desert are tributary to the Ash Meadows discharge area. The contours for the lower carbonate aquifer also indicate that ground water flows into Frenchman Flat from the east and the northeast. This condition suggests that northern Indian Springs Valley (north of U.S. Highway 95), northern Three Lakes Valley (north of U.S. Highway 95), and possibly Desert Valley may also be tributary to the basin.

The potentiometric contours for the valley-fill aquifer and for the Tertiary aquifer and aquitards also provide information on segments of the hydrologic boundary of the Ash Meadows ground-water basin. The potentiometric contours for the valley-fill aquifer in northwestern Las Vegas Valley indicate that water in this aquifer is moving southeastward, whereas the contours for southern Three Lakes Valley indicate that this water is moving northward (pl. 1). A divide is indicated in an area near the intersection of U.S. 95 and Nevada State Highway 52 , but its exact position cannot be identified with existing well control. This ground-water divide in the alluvium probably reflects a divide in the 
lower carbonate aquifer, because elsewhere in the study area head changes in the Cenozoic rocks closely reflect head changes in the underlying pre-Tertiary rocks.

The approximate position of a divide on the northwest side of the Ash Meadows basin is also shown by the potentiometric contours for Cenozoic rocks beneath Emigrant Valley and Pahute Mesa (pl. 1). Southeastward movement of ground water is indicated beneath western Emigrant Valley and southwestward movement beneath Pahute Mesa. The ground-water divide between the basins may lie beneath the Belted Range, which separates the two areas contoured.

Two areas that are not tributary to the Ash Meadows ground-water basin are also delineated by the potentiometric contours for the valley-fill aquifer. The potentiometric contours, the hydraulic barrier(s) extending from Lathrop Wells to Big Spring, and the disposition of the lower clastic aquitard east of Lathrop Wells (pl. 1) indicate that ground water beneath central Amargosa Desert and southwestern Jackass Flats does not discharge at Ash Meadows and is not part of the groundwater basin. This is the same conclusion reached by $\mathrm{O}$. J. Loeltz (written commun., 1960) on the basis of waterlevel data alone. Contours also suggest that groundwater in Pahrump Valley is not moving toward Ash Meadows.

Because water levels in the valley-fill and welded-tuff aquifers of northwestern Jackass Flats and northwestern Amargosa Desert are higher than the water level in Devils Hole (alt 2,359 ft), it may still be argued that water can move from these areas toward Ash Meadows (pI. 1). Such postulated flow might occur not through the Cenozoic aquifers, which appear to contain no areally extensive aquitards to maintain the head needed, but rather through the lower carbonate aquifer, which could maintain the necessary head due to regional confinement by the tuff aquitard. Unfortunately, this argument fails to explain the absence of spring discharge from several outcrops of the lower carbonate aquifer in the central Amargosa Desert; these outcrops (location given previously in the section "Character and Geologic Control of Spring Discharge") are lower than the water level in Devils Hole and should discharge some water if the source of the Ash Meadows discharge is north or northwest of the spring line. The proposed origin from carbonate rocks beneath the northwestern Amargosa Desert also ignores the widespread distribution of the lower clastic aquitard beneath this part of the Amargosa Desert. That the clastic aquitard, rather than the carbonate aquifer, probably underlies the Cenozoic strata is suggested by outcrops of the aquitard (pl. 1), the Roses Well anticline, and well 2506 (pl. 1), which penetrated the lower clastic aquitard immediately beneath the Cenozoic rocks.

\section{INFERRED FROM MAJOR GEOLOGIC FEATURES}

The areal and inferred subsurface disposition of the lower clastic aquitard, the hydraulic basement, permits an estimate of the position of parts of the boundary shown on plate 1 . Geologic character and extent of the Gass Peak thrust fault (structural feature 12 on pl. 1) suggest that most of the recharge to the Sheep Range, particularly to the highest part of the range, may be diverted westward toward Three Lakes and southern Desert Valleys. The thrust fault brings Cambrian and late Precambrian carbonate and clastic rocks over Mississippian to Permian carbonate rocks (Bird Spring Formation). Where exposed, the base of the upper plate consists of the lower clastic aquitard, specifically the lower part of the Carrara Formation, the Wood Canyon Formation, Stirling Quartzite, and Johnnie Formation. Although the lower clastic aquitard is exposed only adjacent to the southern 25 miles of the fault trace, it is probably close to the surface beneath the inferred trace of the fault in northernmost Clark and southernmost Lincoln Counties. There, westward-dipping Middle and Upper Cambrian rocks crop out west of the inferred fault trace, and overturned Mississippian and younger rocks crop out east of the fault trace (Longwell and others, 1965, p. 76 and plate I; Tschanz and Pampeyan, 1961). The argillaceous clastic rocks at the base of the upper plate are missing from outcrop possibly because they are more susceptible to erosion in an arid climate than are carbonate rocks.

Clastic strata are inferred to underlie the carbonate strata for some distance west of the fault trace for three reasons. (1) Both the thrust surface and the bedding planes dip westward. (2) Other westward-dipping major thrust faults in the region (Tippinip, Wheeler Pass, and Montgomery thrust faults) contain westward dipping clastic strata at the base of the upper plate, which suggests that the clastic strata served as the glide plane for the thrust-fault movement, and (3) the fault plane generally dips at a steeper angle than the bedding in the upper plate and hence displaces older clastic rocks with depth; that is, the thrust surface does not cut out the clastic strata but rather increases their thickness (in the upper plate) downdip from the fault trace. (See cross section $B-B^{\prime}$, pl. 1 of Longwell and others, 1965.)

Because of the low gross transmissibility of the clastic rocks, their nearly continuous exposure east of the highest part of the Sheep Range, and their westward dip, they probably form a highly efficient barrier to the eastward movement of ground water within the carbonate rocks. If there were no clastic aquitard or if the aquitard were horizontal or were deeply buried, one might assume that approximately half the recharge to the Sheep Range moves eastward and half moves 
westward; but because of the described disposition of the aquitard, most of the recharge to carbonate rocks in the Sheep Range probably moves to the west toward southern Desert and Three Lakes Valleys. However, the phreatophyte lineament and minor spring discharge (about $125 \mathrm{gpm}$ ) at Corn Creek Ranch and the potentiometric contours for the valley-fill aquifer in northwestern Las Vegas Valley (pl. 1) suggest that some recharge probably also moves southward and thence southeastward into Las Vegas Valley through the valleyfill aquifer.

The movement of significant quantities of ground water eastward across the Gass Peak thrust where it is covered by valley fill opposite the northern half of the Sheep Range (pl. 1) is possible but unlikely. Opposite the southern and by far the loftiest part of the range, major springs are absent at the contact of the lower carbonate aquifer with the lower clastic aquitard (altitude of contact generally ranges from 4,000 to $6,000 \mathrm{ft}$ ). The only significant low-level spring - one at Corn Creek Ranch - emerges at an altitude of about 3,000 feet. This suggests that the carbonate reservoir beneath the Sheep Range is not full of water even opposite the highest and wettest part of the range. By analogy, opposite the northern and much lower half of the range, the water table in the carbonate aquifer may also be lower than its buried contact with the clastic aquitard. If the lower carbonate aquifer is saturated above the altitude of its buried contact with the clastic aquitard, eastward movement would occur only if the tuff aquitard were absent above the buried pre-Tertiary-Tertiary unconformity. In summary, some ground water undoubtedly moves eastward through, or over, the clastic aquitard, but the quantity is probably insignificant compared with that moving westward (and possibly southward) through the carbonate aquifer.

If most of the recharge to the Sheep Range is deflected westward by the subsurface disposition of the clastic and carbonate rocks, then both Three Lakes and southern Desert Valleys are within the Ash Meadows groundwater basin.

The structural disposition of the lower carbonate aquifer and the lower clastic aquitard also suggests that recharge to the Spring Mountains in the central part of Tps. 18-19 S. and Rs. 54-55 E. is tributary to southern Indian Springs Valley, but not to Pahrump Valley as indicated by position of topographic divide (pl. 1). In this area the aquifer lies within the center of a major northward-plunging syncline (structural feature 15 on pl. 1) and is surrounded by the lower clastic aquitard on the southeast, south, and southwest. Thus, unless the aquifer is brimful, a condition not supported by the occurrence of major contact springs (at the contact of the carbonate aquifer and the lower clastic aquitard), recharge should be deflected north into the Ash Meadows ground-water basin.

Disposition of the clastic aquitard was also used to estimate a part of the northwestern and southwestern boundary of the ground-water basin shown on plate 1 . Further discussion of the southwestern boundary (specifically the region between Ash Meadows and Pahrump and Stewart Valleys) is given in the section "Relation to Pahrump Valley Ground-Water Basin."

\section{EXTENT OF BASIN}

A synthesis of the preceding isohyetal, potentiometric, and geologic evidence permits a first approximation of some boundaries of the Ash Meadows ground-water basin, except at the north and northeast (pl. 1). The preliminary basin boundaries encompass an area of about 4,500 square miles; included in the basin are 10 intermontane valleys (Desert Valley, Three Lakes Valley, Indian Springs Valley, Emigrant Valley, Yucca Flat, Frenchman Flat, eastern Jackass Flats, Mercury Valley, Rock Valley, and the unnamed valley in east-central Amargosa Desert).

A northeast boundary for the Ash Meadows groundwater basin cannot be defined on the basis of available geologic or hydrologic evidence. The geologic map of Lincoln County (Tschanz and Pampeyan, 1961) was examined for possible geologic structures which could serve as hydraulic barriers between the north end of the Sheep Range and the north end of the Groom Range; however, no outcrops of the lower clastic aquitard occur in the hills and ridges surrounding Desert Valley and Pahranagat Valley or in the hills separating these valleys from Coal, Garden, and Penoyer (Sand Spring) Valleys. Moreover, the ages of the carbonate rocks shown by the map suggest that the lower clastic aquitard is probably buried thousands of feet beneath the base of the ridges and hills and at still greater depths beneath the valley floors. Outcrops equivalent to the upper clastic aquitard (the Eleana Formation) are scattered throughout the area, but these clastic strata aggregate only a fraction of the thickness of the Eleana Formation at the Nevada Test Site $(7,900 \mathrm{ft})$; the Devonian and Mississippian clastic rocks in the Desert Valley-Pahranagat Valley area aggregate less than 1,500 feet in thickness.

Available water-level data also suggest that ground water may enter the Ash Meadows ground-water basin from Pahranagat, Coal, or Garden Valleys to the northeast. The lowest water-level altitudes in those valleys are 700 to more than 2,000 feet higher than levels within the central Ash Meadows basin (Eakin, 1966).

Eakin (1966) suggested a geologic mechanism that may in part control southwesterly movement of water from southern Pahranagat Valley toward Desert Valley, although he did not suggest such movement. At the 
south end of Pahranagat Valley, near Maynard Lake (pl. 1), the hydraulic gradient shown by Eakin (1966) indicates a barrier within the lower carbonate aquifer. Eakin suggested that the barrier at the south end of Pahranagat Valley is formed by a major fault zone trending southwestward for about 16 miles (structural feature $10 \mathrm{of} \mathrm{pl} .1$ ). If this fault (or a nearby major strikeslip fault zone; feature 9 of p. 1) is responsible for damming the lower carbonate aquifer, it may also deflect some ground water in the aquifer to the southwest toward Nevada Test Site.

Thus, the northeastern extent of the basin cannot be precisely defined from available data; however, the Ash Meadows ground-water basin probably extends at least to the Pahranagat and Timpahute ranges and may possibly include areas further north and east.

Eakin (1966) included Pahranagat, Coal, and Garden Valleys within another vast interbasin ground-water system. He considered the western and the southwestern topographic divides of these valleys as equivalent to a ground-water divide that separates them from Desert Valley. However, he presented no specific hydrologic or geologic evidence in support of the coincidence of the ground water and topographic divides. Precipitation on the Pahranagat Range, which separates Pahranagat Valley from northeastern Desert Valley, ranges from 8 to 12 inches but is mostly less than 10 inches (fig. 3). In addition, a 10-mile-long area between the north end of the Sheep Range and the south end of the Pahranagat Range receives only 7 to 8 inches precipitation (fig. 3). The Timpahute Range, which separates northern Desert Valley from Garden and Coal Valleys, receives 8 to 14 inches precipitation. Because of the low precipitation on these ranges, there need not be a ground-water divide beneath these ranges significant enough to affect regional flow patterns in the lower carbonate aquifer.

In summary, hydraulic connection between the Ash Meadows ground-water basin as delineated on plate 1 and the areas northeast of the basin is probable because (1) the occurrence of interbasin movement in the lower carbonate aquifer in both regions, coupled with the absence of the lower clastic aquitard with the upper part of the zone of saturation between the regions; (2) significant head differences; and (3) the low precipitation ( 7 to $14 \mathrm{in}$.) on the carbonate-rock ridges separating the regions. An estimate of the magnitude of underflow into the Ash Meadows basin from the northeast is given in the section "Underflow from the Northeast."

Underflow southward from the Penoyer Valley, north of Emigrant Valley, may also occur. Such underflow, through either the Cenozoic or the Paleozoic aquifer, would have to pass through or over the lower clastic aquitard, which surrounds western Emigrant Valley (pl. 1 ), before entering the central part of the Ash Meadows basin.

\section{RELATION TO LAS VEGAS GROUND-WATER BASIN}

The approximate boundary of the Ash Meadows ground-water basin (pl. 1) suggests the need for revision of the boundaries of the Las Vegas ground-water basin.

Recharge, regional movement, and discharge of ground water from and the boundaries of the Las Vegas Valley were discussed by George Hardman (written commun., 1931), Maxey and Jameson (1948), and Malmberg (1961 and 1965). All four hydrologists considered the Spring Mountains to be the principal area contributing recharge to the valley-fill reservoir of the Las Vegas ground-water basin, although some recharge from the Sheep Range was inferred. The regional direction of ground-water movement in the valley-fill aquifer was shown to be eastward and northeastward from the Spring Mountains toward the valley and then southeastward toward discharge areas in and east of the city of Las Vegas. Southeastward movement in the northwestern part of the Las Vegas Valley is shown by the potentiometric contours of plate 1 . The contours are modified from Malmberg (1965, pl. 3).

These four hydrologists considered the ridges and mountains flanking the basins to be relatively impermeable, and, in effect, they used topographic divides in outlining the boundaries of the Las Vegas groundwater basin. The boundaries assigned by each to the ground-water basin differed somewhat, however. George Hardman (written commun., 1931) concluded that ground water in Indian Springs Valley, Three Lakes Valley (which he called Owens Dry Lake and Mormon Gulch), and Ivanpah Valley (about 40 miles southsouthwest of Las Vegas) is tributary to the Las Vegas basin. Maxey and Jameson (1948) did not mention Ivanpah Valley and excluded Indian Springs Valley. Their plate 2 shows a south-west trending topographic divide that crosses U.S. Highway 95 about 4 miles east of Indian Springs. North of the highway, the divide follows the crest of the Pintwater Range; south of the highway, it follows Indian Ridge (fig. 1) and continues south to the Spring Mountains. Maxey and Jameson (1948) included at least the southern part of Three Lakes Valley within the Las Vegas basin. Malmberg (1961, pl. 1), like Hardman, considered Ivanpah Valley and Three Lakes Valley to be tributary to the Las Vegas ground-water basin, but he included only the southern part of Indian Springs Valley.

Until recently, the hydrology of the Indian Springs-Three Lakes Valley area was virtually unknown. Few wells had been drilled within the region, and they penetrated only the valley-fill aquifer to shallow depths. Sparsity of data probably accounts for the differing ground-water boundaries that George Hardman (written commun., 1931), Maxey and Jameson (1948), and Malmberg (1961 and 1965) suggested for the Las Vegas ground-water basin. Hydrologic and geologic data 
available since the completion of their work indicates that Indian Springs Valley and most, if not all, of Three Lakes Valley are within the Ash Meadows ground-water basin (pl. 1). However, the exact position of the divide between the Ash Meadows and Las Vegas Valley groundwater basins is still open to question.

Corn Creek Springs and the northwest-trending phreatophyte lineament at the south end of the Sheep Range (pl. 1) indicate that some of the recharge to the Sheep Range probably flows into Las Vegas Valley, rather than toward Three Lakes Valley. The phreatophyte lineament is controlled by faults (Haynes, 1965); the lineament also nearly coincides with the position of the Las Vegas Valley shear zone (structural feature 13, pl. 1). That this recharge to Las Vegas Valley probably does not exceed a few thousand acre-feet annually is suggested by the following:(1) Geologic structure suggests that the lower clastic aquitard may be present along the Las Vegas Valley shear zone; and (2) the discharge of Corn Creek Springs is only $125 \mathrm{gpm}$ (Malmberg, 1965, table 8), and that of other springs in the area is but a fraction of this amount.

\section{RELATION TO PAHRUMP VALLEY GROUND-WATER BASIN}

Plate 1 indicates that ground water in Pahrump Valley and in Stewart Valley is not tributary to the Ash Meadows ground-water basin. However, a wide divergence of opinion exists on the degree of hydraulic connection of these areas.

Loeltz (written commun., 1960) noted that recharge to the Pahrump Valley ground-water basin, estimated by Maxey and Jameson (1948), greatly exceeded estimates of natural discharge from Pahrump Valley. He therefore concluded that some of the discharge at Ash Meadows probably came from the southwest slope of the Spring Mountains via Pahrump Valley. Also favoring such flow, according to Loeltz, are the following factors: (1) The westward slope of the potentiometric surface in Pahrump Valley; (2) the altitude of the water surface in Pahrump Valley, which is several hundred feet higher than that in Devils Hole; (3) possible hydraulic conduits through the highly deformed carbonate rocks that form part of the topographic boundary between the two areas; and (4) the possibility that the chemical quality of the ground water in Pahrump Valley might change between the two areas and attain the same chemical quality as that discharged by the springs. Loeltz also recognized, however, that some of the spring discharge might have come from areas to the north and northeast of Ash Meadows.

On the basis of Maxey and Jameson's work (1948) and estimates of natural discharge in Pahrump Valley, Walker and Eakin $(1963$, p. 21) suggested that possibly 13,000 of the 17,000 acre-feet of annual spring discharge at Ash Meadows is derived from Pahrump Valley and that the remaining 4,000 acre-feet of discharge is derived annually from carbonate rocks northeast of Ash Meadows. Winograd (1963), on the basis of an oral communication from G. T. Malmberg (1962), stated "that about 11,000 acre-feet of the spring discharge at Ash Meadows represents underflow from Pahrump Valley via carbonate aquifers." Hunt, Robinson, Bowles, and Washburn (1966) concluded that "Pahrump Valley seems to be the source of the ground-water discharge at the large springs at Ash Meadows and possibly at some of the other large warm ones farther south in the Amargosa River drainage." Their conclusion was primarily based on the arguments stated by Loeltz (1960) and supplementary geomorphic evidence. They placed greater emphasis on the similarity of the chemistry of water in the Pahrump Valley-Ash Meadows area than did Loeltz, but, like Loeltz, they did not assign a value for the percentage of the total Ash Meadows discharge presumably derived from Pahrump Valley. Nor did they discuss possible underflow toward Ash Meadows from the north or northeast.

Since the completion of the fieldwork associated with the preceding studies, Malmberg (1967, p. 32-33) completed a study of the ground-water hydrology of Pahrump Valley, and R. H. Moench (written commun., Mar. 1965) mapped the geology of the hills between Pahrump Valley and Ash Meadows. On the basis of his own work and the geologic mapping of Moench, Malmberg concluded that 12,000 acre-feet per year of ground-water underflow leaves Pahrump Valley through both the Paleozoic carbonate rocks (10,000 acre-ft per yr) and the valley-fill aquifer $(2,000$ acre-ft per yr). He believed that most of this underflow is toward the Nopah and Resting Spring Ranges, which border Pahrump Valley on the southwest (pl. 1), but said "part may move northwestward through a thin section of carbonate rocks or along major fault zones to the springs at Ash Meadows." The evidence Malmberg (1967, p. 24) cited in favor of a southwestward movement of the bulk of the underflow is the following: (1) "Except for a small wèdge of carbonate rocks north of Stewart Valley, the reservoir is terminated by structural deformation along the northwest side of Pahrump Valley, where quartzite and other poorly permeable rocks crop out"; (2) the potentiometric contours for the valley fill indicate southwestward movement of water across the valley (Malmberg presumed that the direction of flow in the carbonate rock reservoir also is southwestward); (3) the configuration of the potentiometric contours and the absence of a shallow water table beneath southwestern Pahrump Valley suggests that ground water is moving into rather than being dammed by the Nopah and Resting Spring Ranges (the Nopah Range is composed predominantly of carbonate rocks, which favor such movement; the Resting Spring Range, on the other 
hand, has a clastic-rock core); and (4) water quality does not support movement of water from Stewart Valley toward Ash Meadows.

Malmberg (1967, p. 25-26) did not discount the possibility of some movement to the northwest because (1) "The small wedge of carbonate rocks north of Stewart Valley provides a potential avenue of flow northwestward to the springs in Ash Meadows - Last Chance, Bole, Big, and Jack Rabbit Springs, which issue at depth from carbonate rocks" and (2) the head differential between northern Stewart Valley and Ash Meadows (about $80 \mathrm{ft}$ ) favors northwestward movement. He concluded, "until the head distribution in the carbonate rocks in Pahrump and Stewart Valleys and in the intervening area to the northwest is known, the possibility of northwestward flow to the springs must remain unresolved."

Hughes (1966) inferred in his study of springs in the Spring Mountains that as much as 3,000 acre-feet of water may move annually toward Ash Meadows from the Spring Mountains via Pahrump Valley and that the remainder of the Ash Meadows discharge comes from the north and northeast.

In summary, these cited studies suggest that as much as 13,000 or as little as 3,000 acre-feet of the yearly discharge at Ash Meadows (roughly 75 and 20 percent of the spring flow) is derived from Pahrump Valley via underflow through Paleozoic carbonate rocks.

The authors of this report conclude that at most only a small percentage of the Ash Meadows discharge originates in Pahrump Valley. Evidence for this follows:

1. The lower clastic aquitard crops out in a nearly continuous band between Pahrump and Stewart Valleys and the east-central Amargosa Desert (pl. 1). Geologic sections by R. H. Moench (written commun., Mar. 1965) suggest further that the lower clastic aquitard is probably also the principal pre-Tertiary rock within the zone of saturation beneath the small valleys and arroyos separating the ridges of pre-Tertiary rocks (pl. 1). Minor carbonate strata also occur locally within the zone of saturation, as suggested by Malmberg (1967), but the cross sections indicate that they are not continuous between Pahrump and Stewart Valleys and the Amargosa Desert; if the cross sections are in error, the carbonate rocks still do not constitute an important fraction of the pre-Tertiary rocks within the zone of saturation. The distribution of the clastic rocks between the north end of Stewart Valley and the Johnnie mining district is controlled by the Montgomery thrust fault (structural feature 16 of pl. 1), which resembles the Gass Peak and the Wheeler Pass thrust faults. The fault plane dips westward at an angle in excess of $25^{\circ}$. The base of the upper plate consists of late Precambrian clastic rocks that dip westward and northwestward but generally at a gentler angle than the fault plane. The overridden rocks consist of Devonian to Mississippian carbonate rocks. Thus, this thrust probably isolates ground water in the lower carbonate aquifer and in the Cenozoic aquifers in northwestern Pahrump Valley from the same aquifers in the east-central Amargosa Desert. Data on interstitial permeability and fracture transmissibility in similar rocks in Yucca Flat were used to estimate the potential maximum underflow through a 10-mile-long strip of the lower clastic aquitard (between the northern Stewart Valley and a point near Johnnie). The lower clastic aquitard was assumed to be 10,000 feet thick (full thickness); the hydraulic gradient was assumed to be 200 feet per mile. (This represents a probable maximum gradient, because the difference in water level between northwestern Pahrump Valley and Devils Hole is about $200 \mathrm{ft}$.) A permeability value of $0.0001 \mathrm{gpd}$ per sq $\mathrm{ft}$ was taken from table 4 ; this value is the maximum listed for interstitial permeability. The calculated underflow amounts to 2,000 gpd, or about $1 \mathrm{gpm}$. Evidence that regional flow through the clastic aquitard is probably controlled by flow through interstices rather than through fractures was presented in the section "Lower Clastic Aquitard." Nevertheless, assuming an improbable average coefficient of transmissibility of $1,000 \mathrm{gpd}$ per $\mathrm{ft}$ between the two areas and a hydraulic gradient of 200 feet per mile, an underflow rate of about $1,400 \mathrm{gpm}$, or about 13 percent of the Ash Meadows spring discharge, is computed.

2. Comparison of the chemical quality of the water in Pahrump and Stewart Valleys with that at Ash Meadows precludes movement of significant quantities of water from these valleys toward Ash Meadows. Such a comparison is discussed under "Ground-Water Chemistry, Hydrochemical Facies, and Regional Movement of Ground Water."

3. Depth to and altitude of the water table in Stewart Valley and in northwestern Pahrump Valley also suggest that these valleys are separated from Ash Meadows by a relatively impermeable barrier. The water table beneath the playas in northern Stewart and northwestern Pahrump Valleys is only a few feet below the surface, or at an altitude of about 2,440 and 2,550 feet, respectively (Malmberg, 1967; pl. 1). These water-level altitudes are about 80 and 190 feet higher than the water-level altitude $(2,359$ $\mathrm{ft}$ above mean sea level) in the lower carbonate aquifer at Devils Hole. In contrast, the water table beneath the playa in southwestern Pahrump Valley is at an altitude of about 2,420 feet (Malmberg, 1967 ; pl. 1), but it is fully 100 feet below the playa 
level. Thus, the water table beneath this playa is 20 feet lower than the water table beneath the playa in northern Stewart Valley and is 130 feet lower than that beneath the playa in northwestern Pahrump Valley. The water table in the valley-fill aquifer in northern Stewart Valley and in northwestern Pahrump Valley thus stands well above levels in the same aquifer to the south-southeast and to the northwest. This difference in altitude and saturation of the valley fill nearly to the surface beneath the playas in Stewart and western Pahrump Valleys suggest that the ground water in these areas is ponded by some impermeable boundary, namely, the lower clastic aquitard. Such ponding does not preclude underflow of small magnitude. In contrast, the playa in southwestern Pahrump Valley is bordered on the southwest by the Nopah Range, which is composed predominantly of the lower carbonate aquifer. Malmberg's (1967) potentiometric contours for the valley-fill aquifer reproduced on plate 1 of this report indicate that ground water in this aquifer is moving toward (and into) the Nopah Range.

In summary, the preceding evidence indicates that at most only a few percent of the Ash Meadows discharge can be derived from either Stewart Valley or western and northwestern Pahrump Valley.

\section{SOURCES OF RECHARGE TO THE LOWER CARBONATE AQUIFER}

Within the basin boundary delineated on plate 1 , the lower carbonate aquifer is recharged principally by precipitation in areas of high rainfall and favorable rock type and secondarily by downward leakage of water from the Cenozoic hydrogeologic units. Underflow into the basin from the northeast may also constitute a major source of recharge.

\section{PRECIPITATION}

Recharge from precipitation is probable beneath and immediately adjacent to the highly fractured Paleozoic carbonate rocks of the Sheep Range, northwestern Spring Mountains, southern Pahranagat Range (south of State Highway 25; fig. 1), and, to a lesser extent, beneath the Pintwater, Desert, and Spotted Ranges. The approximate average annual precipitation within the Ash Meadows basin is about 320,000 acre-feet on the Sheep . Range, about 100,000 acre-feet on the northwestern Spring Mountains, and about 90,000 acrefeet on the southern Pahranagat Range (fig. 3). For these mountains, the 8-inch isohyetal contour roughly corresponds with the lowest outcrop of Paleozoic bedrock, Precipitation on the lower Desert, Pintwater, and Spotted Ranges was estimated only for those parts of the ranges receiving 8 inches or more rainfall. This amounted to about 60,000 acre-feet.
Thus, a total of about 570,000 acre-feet of precipitation falls annually within the basin on prominent ridges and mountains that are composed principally of the lower carbonate aquifer. This quantity is an approximation at best: precipitation that falls on carbonate-rock outcrops at low altitudes in the Spotted, Pintwater, or Desert Ranges or on the other minor hills and ridges in the region was not included; conversely, some of the precipitation included in the tabulation falls on the valley fill bordering the mountains, or on clastic rock, and not on the lower carbonate aquifer; it should be subtracted from the total. The preceding estimate could have been refined by planimetering the area of carbonate-rock outcrop for select altitude zones and by applying Quiring's (1965) altitude-precipitation curves of the region; however, such precision is unwarranted because of the approximate nature of the basin boundary.

Precipitation falling on the valley floors underlain by carbonate rocks was not estimated because recharge to either the lower carbonate aquifer or the younger aquifers beneath such areas seems improbable under present climatic conditions. Moreover, recharge to carbonate rocks beneath the valleys is controlled by the tuff aquitard.

Assuming that the spring discharge at Ash Meadows is derived principally from precipitation falling on carbonate-rock uplands within the boundaries of the Ash Meadows basin (pl. 1) and that steady-state conditions exist in the ground-water basin, the percentage of rainfall that infilitrates to the carbonate aquifer beneath the ranges can be estimated. Using the 17,100 acre-feet of measured spring discharge (average of two values given in table 7) and the precipitation estimate of roughly 570,000 acre-feet, about 3 percent of the rainfall falling on areas of carbonate-rock outcrop may infiltrate to the zone of saturation. The cited percentage of infiltration is in error in proportion to (1) the magnitude of underflow into the basin from the northeast, (2) underflow out of the basin at Ash Meadows, and (3) evapotranspiration in Ash Meadows discharge area in excess of that supported by recycled spring discharge.

\section{UNDERFLOW FROM THE NORTHEAST}

Geologic and hydrologic evidence presented in the section "Areal Extent of the Ground-Water Basin" indicates that the Ash Meadows ground-water basin may receive underflow from the northeast, but this evidence does not permit estimation of the quantity of underflow. A comparison of the deuterium content of ground water in Pahranagat Valley, along the flanks of the Spring Mountains and Sheep Range, and at Ash Meadows indicates that possibly as much as 35 percent (about 6,000 acre-ft annually) of the Ash Meadows discharge may enter the basin from the northeast. The deuterium data 
are discussed in the section "Underflow from Pahranagat Valley."

\section{DOWNWARD LEAKAGE FROM CENOZOIC ROCKS}

A minor source of recharge to the lower carbonate aquifer is downward leakage of ground water semiperched in the Cenozoic rocks. In Yucca Flat, the magnitude of downward leakage was estimated, on the basis of hydraulic data, to be in the range of 25-65 acrefeet per year. Downward leakage of similar magnitude is probable also in Frenchman Flat.

By analogy with Yucca and Frenchman Flats, downward leakage of water probably also occurs beneath Desert Valley, eastern Emigrant Valley, the northern two-thirds of Three Lakes Valley, and the northern twothirds of Indian Springs Valley. These four valleys have hydrogeologic settings similar to those of Yucca and Frenchman Flats. (See section "Intrabasin Movement.") The vertical leakage of the semiperched water in these valleys may also be on the same order. The aggregate leakage beneath the six valleys is estimated, then, to be between 150 and 400 acre-feet per year, or less than 3 percent of the discharge at Ash Meadows. Calculations of leakage based on hydrochemical evidence are given below in the section "Estimates of Downward Crossflow from the Tuff Aquitard into the Lower Carbonate Aquifer."

\section{QUANTITY DERIVED FROM NORTHWEST SIDE OF BASIN}

The quantity of recharge entering the lower carbonate aquifer from the northwest side of the basin is probably only a few percent of the measured discharge at Ash Meadows. The northwestern border of the Ash Meadows basin is defined approximately by the crest of Belted Range, Rainier Mesa, and Eleana Range uplands, which receive 8 to 14 inches of annual rainfall. An estimate of the quantity of this precipitation that eventually reaches the lower carbonate aquifer within the central and southwestern parts of the basin may be obtained by calculating the eastward and southward underflow across the nearly continuous trend of clastic rocks extending from the north end of the Groom Range to western Jackass Flats (pl. 1); this trend is as much as 15 miles east of the basin boundary (pl. 1).

The annual quantity of basinward underflow through the lower clastic aquitard and into the lower carbonate aquifer between the northeast end of Groom Lake playa and northern Yucca Flat is probably less than 40 acrefeet. This value was determined by applying the following values of $T, I$, and $L$ to the underflow equation $(Q=T I L)$. The coefficient of transmissibility, $T$, assumed to be about $1 \mathrm{gpd}$ per $\mathrm{ft}$, was determined by multiplying the highest value of coefficient of interstitial permeability measured in the laboratory $(0.0001$ gpd per sq ft; table 4) by 10,000 feet, a maximum probable thickness of aquitard. The apparent hydraulic gradient, $I$, within the lower clastic aquitard ranges from 250 to 1,300 feet per mile (fig. 32); a gradient of 1,000 feet per mile was used to maximize the underflow. The length of underflow strip $L$, is about 35 miles; it is the distance measured along the inferred contact between carbonate and clastic rock between the northeast end of the playa and the northern tip of Yucca Flat (pl. 1).

Eastward underflow into the lower carbonate aquifer (east of the Groom Range) between northeastern Groom Lake playa and the north end of Groom Range may amount to about 20 acre-feet annually if hydraulic gradients as steep as those shown in figure 32 occur beneath clastic rocks of the Groom Range.

Eastward underflow through the valley-fill aquifer between the Groom and the Papoose Ranges (fig. 32) also probably reaches the lower carbonate aquifer beneath eastern Emigrant Valley after passage through the tuff aquifers and aquitards. The coefficient of transmissibility of the valley-fill aquifer is not less than 30,000 gpd per ft in two wells (91-74 and 91-74a) in western Emigrant Valley (table 3), and the hydraulic gradient may be as much as 4 feet per mile toward the playa (fig. 32). The playa is about 3 miles wide, but the clastic aquitard is above the zone of saturation locally (fig. 32). Assuming a coefficient of transmissibility of $30,000 \mathrm{gpd}$ per $\mathrm{ft}$, a hydraulic gradient of 4 feet per mile, and an underflow strip 1.5 mile wide, the flow across the barrier via the valley-fill aquifer is about 200 acre-feet annually. This figure is probably a maximum value because thinning of the valley-fill aquifer near the buried aquitard would probably result in a reduction in transmissibility.

Underflow through the Cenozoic aquifers elsewhere along the boundary between carbonate and clastic rock between northern Groom Range and northern Yucca Flat appears negligible. The valley-fill aquifer west of Groom Lake is nearly fully saturated only because of the damming effect of the clastic aquitard, which nearly surrounds western Emigrant Valley. However, in general, the Cenozoic aquifers are probably unsaturated because of their structurally high position; in Yucca Flat, for example, the Cenozoic aquifers are unsaturated along the borders of that valley. The tuff aquitard, however, may be saturated in a structurally high position because of its very low transmissibility; but owing to its thinness, underflow through the tuff aquitard is probably a fraction of that through the thick lower clastic aquitard.

Eastward underflow into the lower carbonate aquifer beneath central Yucca Flat can follow two routes: (1) flow through the upper clastic aquitard (pl. 2), and (2) flow through the lower carbonate aquifer underlying the upper clastic aquitard. Underflow through the Cenozoic aquifers overlying the upper clastic aquitard is unlikely 
for reasons outlined in the preceding paragraph; minor underflow through the tuff aquitard is possible.

Maximum flow through the upper clastic aquitard along the west side of Yucca Flat is about 30 acre-feet annually when computed with the same values for transmissibility and hydraulic gradient used to calculate flow through the lower clastic aquitard.

The quantity of eastward underflow into Yucca Flat through the lower carbonate aquifer underlying the upper clastic aquitard is difficult to estimate and probably depends in part on the subsurface nature of the Tippinip thrust fault. (See discussion in section "Northwestern and West-Central Yucca Flat.") Available data suggest such underflow is probably minor. First, the high waterlevel altitudes $(3,800 \mathrm{ft})$ in the upper clastic aquitard beneath the western half of Yucca Flat (pl. 2, C) suggest that the head within the underlying lower carbonate aquifer may be considerably higher than that in the same aquifer east of the Tippinip thrust fault (pl. $2 \mathrm{C}$ ); this in turn suggests a hydraulic barrier between the carbonate rocks east and west of the fault. However, the water in the aquitard may be semiperched above the lower carbonate aquifer, whose head is no higher than beneath central Yucca Flat (alt about 2,400 ft). Second, the CP thrust fault (structural feature 2 on pl. 1), believed to extend as far southwest as northwestern Jackass Flats, may be rooted in Precambrian clastic rocks (Barnes and Poole, 1968); this fault may thus structurally and hydraulically isolate carbonate rocks of western Yucca Flat from similar rocks west of the fault. Third, the Eleana Range and Shoshone Mountain are bordered on the west by the eastern rim of two calderas, the Timber Mountain caldera (Carr, 1964; Christiansen and others, 1965) and the Silent Canyon caldera (Noble and others, 1968; Orkild and others, 1968). The approximate position of the rim of the Timber Mountain caldera is shown on plate 1 ; this caldera generally ranges from 15 to 20 miles in diameter. The Silent Canyon caldera is centered beneath Pahute Mesa immediately north of the Timber Mountain caldera; this caldera is roughly elliptical in plan and measures 10 by 14 miles (Orkild and others, 1968). Test drilling has shown that at least 13,500 feet of volcanic rocks underlie the Silent Canyon caldera. Gravity surveys suggest that the Silent Canyon caldera may be underlain by as much as 15,000 to 16,000 feet of Tertiary volcanic rocks and the Timber Mountain caldera by as much as 12,000 feet of volcanic rocks (D. L. Healey and C. H. Miller, written commun., 1966). Whether these volcanic rocks are underlain directly by pre-Tertiary miogeosynclinal rocks or are underlain directly by a magma chamber or whether the miogeosynclinal rocks are present, but largely dismembered by stoping, will probably never be known. However, limited outcrops of silicic intrusive rocks within the Timber Mountain caldera suggest that a magma chamber may underlie the volcanic rocks filling the caldera. In summary, because of the two major volcano-tectonic features briefly described and possibly the CP thrust fault, the lower carbonate aquifer underlying the upper clastic aquitard in western Yucca Flat and northern Jackass Flats is probably not structurally or hydraulically continuous with the carbonate aquifer (if any) beneath the two calderas or beneath areas west and north of the calderas. Therefore, the quantity of eastward underflow through the lower carbonate aquifer into Yucca Flat may be restricted to downward leakage from the overlying upper clastic aquitard and possible lateral movement eastward from the tuff and lava-flow aquitards beneath the calderas. Such underflow is unlikely to exceed 200 acre-feet annually. Similarly, the flow into the basin across the eastwest-trending contact of the upper clastic aquitard and the lower carbonate aquifer, between northwestern Frenchman Flat and northeastern Jackass Flats (pl. 1), is probably less than 100 acre-feet per year.

The total underflow of water into the lower carbonate aquifer from the northwest side of the Ash Meadows ground-water basin probably amounts to less than 600 acre-feet per year, or about 4 percent of the measured discharge at Ash Meadows.

The estimated quantity flowing into the lower carbonate aquifer beneath Yucca Flat, from both northeast and west, is about 250 acre-feet per year, or about 1 percent of the discharge at Ash Meadows. The lower carbonate aquifer beneath Yucca Flat is also recharged by downward leakage of water semiperched in the Cenozoic hydrogeologic units; this leakage probably ranges from 25 to 65 acre-feet per year. (See section "Intrabasin Movement.") Precipitation falling directly on the low carbonate-rock ridges bordering Yucca Flat on the east probably contributes minor recharge. The total flow within the lower carbonate aquifer beneath Yucca Flat probably is less than 350 acre-feet per year.

\section{OASIS VALLEY-FORTYMILE CANYON GROUND-WATER BASIN}

Ground water beneath the western half of Nevada Test Site - the Pahute Mesa-Timber Mountain area is not tributary to the Ash Meadows ground-water basin. This ground water, predominantly in Tertiary tuff and rhyolite, moves southwestward toward discharge areas in Oasis Valley (pl. 1) and probably also moves southward toward the Amargosa Desert through western Jackass Flats. This area is tentatively considered part of a single ground-water basin, informally designated the Oasis Valley-Fortymile Canyon basin, which is tributary to the central and northwestern Amargosa Desert.

The hydrologic boundaries of the Oasis Valley-Fortymile Canyon ground-water basin have not yet been fully defined. Malmberg and Eakin (1962) recognized 
that the boundaries of the area contributing ground water to this basin need not correspond with the surface drainage basin. Test drilling on Pahute Mesa in 1963-65 substantiated their prediction (R. K. Blankennagel and J. E. Weir, written commun., 1966). The generalized potentiometric contours for the Pahute Mesa area (pl. 1) suggest that some ground water flows from Pahute Mesa toward Oasis Valley and that the water beneath Pahute Mesa may, in turn, be derived from Kawich Valley to the northeast. Thus, interbasin movement of water also is through the volcanic rocks (at least the younger volcanic rocks) within the Oasis Valley-Fortymile Canyon basin. A tentative position of the ground-water divide between the Ash Meadows ground-water basin and the Oasis Valley-Fortymile Canyon ground-water basin is shown on plate 1 .

The ground-water hydrology of the Oasis Valley-Fortymile Canyon ground-water basin was described by Blankennagel and Weir (1973).

\section{PROBABLE HYDRAULIC CONNECTION BETWEEN CENTRAL AMARGOSA DESERT AND FURNACE CREEK WASH-NEVARES SPRINGS AREA IN DEATH VALLEY}

The Furnace Creek Wash-Nevares Springs discharge area lies in east-central Death Valley (fig. 1 and pl. 1). Altitudes in the area range from 200 feet below to about 1,000 feet above sea level. The area is the center of tourism in the Death Valley National Monument and includes the following wellknown attractions: Furnace Creek Inn, Furnace Creek Ranch, Texas Spring campground, and Zabriskie Point. Furnace Creek Wash (pl. 1), a major northwestward draining arroyo, marks the southwestern border of the area, and the Funeral Mountains mark the northeastern border; the Death Valley salt pan borders the area on the west.

Annual precipitation at Furnace Creek Ranch (alt 168 $\mathrm{ft}$ below sea level) is 1.66 inches (47-yr record), and pan evaporation at Cow Creek (alt about $160 \mathrm{ft}$ below sea level) is 149 inches (3-yr record). The average annual temperature at Furnace Creek Ranch was $24.0^{\circ} \mathrm{C}$ for the period 1911-52; for the same period the average July temperature was $39.0^{\circ} \mathrm{C}$, and the average January temperature was $10.5^{\circ} \mathrm{C}$. Temperatures of $49.0^{\circ} \mathrm{C}$ or higher are not uncommon during May through September; a high of $56.5^{\circ} \mathrm{C}$ has been recorded in July (Hunt and others, 1966, p. B7-B9).

Water for the area is derived principally from three groups of springs - Travertine Springs, Texas Spring, and Nevares Springs ( $\mathrm{pl} .1$ ). The hydrogeologic setting at these springs was described briefly by Pistrang and Kunkel (1964) and by Hunt, Robinson, Bowles, and Washburn (1966). Travertine and Texas Springs issue from Quaternary gravels underlain at shallow depth and partly surrounded by Tertiary lacustrine deposits. These springs discharge about 850 and $225 \mathrm{gpm}$, respectively; the water temperature is about $33.5^{\circ} \mathrm{C}$. Travertine Springs are about 400 feet and Texas Spring 380 feet above sea level. The main spring at Nevares Springs emerges from a travertine mound about 100 feet from an outcrop of the lower carbonate aquifer (Bonanza King Formation). Discharge of this spring is $270 \mathrm{gpm}$; the temperature of the water is $40.0^{\circ} \mathrm{C}$, and the altitude of the spring is 937 feet above sea level. Ground water is also discharged by small springs, evapotranspiration, and seepage into tunnels and tile fields.

The estimated total discharge in the area is about 2,500 gpm, or about 4,100 acre-feet per year (Pistrang and Kunkel, 1964, table 4). Hunt, Robinson, Bowles, and Washburn (1966) estimated a total discharge of about 3,200 gpm (about 5,100 acre-ft) for a larger discharge area than that considered by Pistrang and Kunkel.

Pistrang and Kunkel (1964) considered the discharge to be derived from precipitation on the highlands bordering Death Valley on the east. The estimated size of the catchment area was between 30 and 150 square miles. They suggested that the spring discharge is fed by a combination of ground water moving along faults in preTertiary and Tertiary rocks, through travertine conduits, and through permeable gravel lenses. In contrast, Hunt, Robinson, Bowles, and Washburn (1966, p. B40) suggested that the spring discharge "is derived directly from Pahrump Valley, by movement along faults in the bedrock under the valley fill." Elsewhere in the same report (p. B1) they suggested that the discharge is derived from Pahrump Valley "by way of Ash Meadows."

The major springs in the Furnace Creek Wash-Nevares Springs area - Travertine Springs, Texas Spring, and Nevares Springs - are probably fed by upward leakage from the lower carbonate aquifer, as are major springs at Ash Meadows, Pahranagat Valley, and many other places in eastern Nevada. Hunt and Robinson (1960) suggested that the major springs in the Furnace Creek Wash-Nevares Springs area, though they emerge from Quaternary deposits, represent discharge from Paleozoic carbonate rocks, but they offered no supporting evidence. Evidence in support of this belief follows:

(1). Nevares Springs, at the foot of the Funeral Mountains (pl. 1), are about 100 feet from the topographically lowest outcrop of the lower carbonate aquifer (Bonanza King Formation) in the area (Hunt and Mabey, 1966, pl. 1). Minor seeps emerge directly from the carbonate aquifer a few hundred feet south of the main spring. The setting of these springs is generally similar to that of major springs at Ash Meadows, in Indian Springs Valley, 
and in Pahranagat Valley; in those valleys (and elsewhere in eastern Nevada) springs also emerge from Paleozoic carbonate rocks, or from valley fill adjacent to carbonate rocks, at topographically low outcrops in, or along the margins of, the intermontane valleys.

(2). At Ash Meadows the springs closest to the outcrop of the lower carbonate aquifer generally had the highest temperature. (See section "Character and Geologic Control of Spring Discharge.") This same relation exists among the major springs in Death Valley. The temperature of water from Nevares Springs is about $6.5^{\circ} \mathrm{C}$ higher than that of water from Texas or Travertine Springs, even though Nevares Springs are about 540 feet higher in altitude. The higher temperature of Nevares Springs is explained by the direct hydraulic connection between the lower carbonate aquifer and the spring orifices. In contrast, pre-Tertiary carbonate rocks are at least hundreds and possibly more than 2,000 feet below the surface at Texas and Travertine Springs (Mabey, 1963); accordingly, lower temperature would be expected at these springs due to loss of heat to the Tertiary rocks during movement of water from the carbonate aquifer to the surface.

(3). As noted by Pistrang and Kunkel (1964, p. Y32) and by Hunt, Robinson, Bowles, and Washburn (1966, p. B38), the chemical quality of the water from the three major springs is nearly identical. Water chemistry thus provides a further clue that water from Travertine and Texas Springs, like that at Nevares Springs, is derived from the lower carbonate aquifer.

Notions regarding the nature of the hydraulic barrier(s) forcing water out of the carbonate aquifer at Nevares Springs and the mode of hydraulic connection between the spring orifices and the deeply buried carbonate aquifer at Texas and Travertine Springs are not discussed here. Several models can be visualized through the geologic maps, cross sections, and block diagrams presented by Hunt and Mabey (1966) and by Pistrang and Kunkel (1964).

Underflow toward Death Valley through the lower carbonate aquifer requires that three conditions be met. First, the lower carbonate aquifer must extend from the Furnace Creek Wash-Nevares Springs area to the central or south-central Amargosa Desert; second, a favorable hydraulic potential must exist for movement westward through this aquifer; and third, a source(s) of recharge to the lower carbonate aquifer must be available.

The lower carbonate aquifer crops out in a nearly continuous band between the south-central Amargosa Desert and the Furnace Creek Wash-Nevares Springs area (Jennings, 1958). The Death Valley sheet of the geologic map of California (Jennings, 1958) and the geologic map of Death Valley by Hunt and Mabey (1966) show that carbonate rocks, Cambrian through Devonian in age, crop out across the south end of the Funeral Mountains; the strata extend from T. 26 N., R. 5 E., and T. 27 N., R. 4 E., on the east (where they border southcentral Amargosa Desert) to Nevares Springs on the west, a distance of about 20 miles. The approximately wedgelike outcrop pattern tapers from about 12 miles wide on the northeast and east to less than 1 mile wide at Nevares Springs. Paleozoic carbonate rocks are absent in the parts of the Funeral Mountains and the Black Mountains that border this carbonate-rock wedge on the north and south (pl. 1). Thus, assuming that the carbonate rocks also are within the zone of saturation, a possible route exists for interbasin movement of ground water from the south-central Amargosa Desert to the area of major spring discharge in Death Valley.

The assumption that the carbonate rocks are thick enough to lie within the zone of saturation appears safe. The geologic map of the area by Jennings (1958) shows that the bulk of the carbonate rocks cropping out between south-central Amargosa Desert and Furnace Creek are of Ordovician age or younger; hence, thousands of feet of carbonate rocks probably lie within the zone of saturation, the top of which ranges from 900 to 2,200 feet in altitude. Therefore, the lower clastic aquitard is unlikely to lie above the zone of saturation in a continuous band between the two valleys. The lower carbonate aquifer between the south-central Amargosa Desert and the Furnace Creek Wash-Nevares Springs area thus afford an avenue for ground water to move from the Amargosa Desert into Death Valley.

A hydraulic gradient with a westward component should exist within the lower carbonate aquifer because the difference in the land-surface altitude between the south-central Amargosa Desert $(2,400 \mathrm{ft})$ and the Nevares Springs area $(937 \mathrm{ft})$ is nearly 1,500 feet. The water level in the valley-fill aquifer in south-central Amargosa Desert ranges from about 2,100 to 2,200 feet above mean sea level, or about 1,200 feet above the orifices of Nevares Springs. The distance between south-central Amargosa Desert and Nevares Springs ranges from 10 to 20 miles and suggests an average hydraulic gradient of 60 to 120 feet per mile between the two areas. This gradient, which is anomalously high for the lower carbonate aquifer, suggests that one or more hydraulic barriers probably exist within the lower carbonate aquifer in the area.

Ground water in the lower carbonate aquifer beneath the south-central Amargosa Desert may be derived from two sources: direct southwestward underflow from the Ash Meadows ground-water basin through the lower carbonate aquifer (assuming the aquifer is extensive 
beneath the central Amargosa Desert), and downward leakage from the valley-fill aquifer beneath the central and south-central Amargosa Desert. Water in the valleyfill aquifer may have been derived from spring runoff at Ash Meadows, from Jackass Flats, or from northwestern Amargosa Desert. Important quantities of water from the valley-fill aquifer could leak downward only if the head in the valley fill beneath the central and southcentral Amargosa Desert were higher than that in the underlying carbonate aquifer and if the lower carbonate aquifer and valley fill were in direct hydraulic continuity near buried structural highs where the Tertiary aquitard may not have been deposited or may have been removed by erosion prior to deposition of the valley fill. Data on the head relation between the two aquifers beneath the central and south-central Amargosa Desert are not available.

The minimum area of the Ash Meadows basin is about 4,500 square miles and the minimum discharge is about 17,000 acre-feet. In contrast, the superficial watershed tributary to the springs in Death Valley is 150 square miles (Pistrang and Kunkel, 1964), and the discharge exceeds 4,000 acre-feet. In addition, the Ash Meadows ground-water basin encompasses two of the highest mountain ranges in southern Nevada, whereas the Death Valley catchment area is the most arid in the Nation. Because of this relation and the foregoing hydrogeologic information, the authors suggest that most of the spring discharge in the very arid Furnace Creek Wash-Nevares Springs area (possibly more than 95 percent) originates outside of Death Valley.

Hunt, Robinson, Bowles, and Washburn (1966) suggested that the spring discharge in Death Valley comes principally from Pahrump Valley, either directly or through Ash Meadows. The present authors have previously considered that movement of significant quantities of ground water from Pahrump or Stewart Valleys to Ash Meadows is unlikely. (See section, "Relation to Pahrump Valley Ground-Water Basin.") Direct movement to Death Valley from Pahrump Valley also appears unlikely because the Resting Spring Range, which borders Stewart Valley and Chicago Valley on the west, is composed chiefly of the lower clastic aquitard (pl. 1).

\section{GROUND-WATER CHEMISTRY, HYDROCHEMICAL FACIES, AND REGIONAL MOVEMENT OF GROUND WATER}

Chemical analyses are available for ground water from 147 sources: 74 wells, 49 springs, and 24 water-bearing fractures in underground workings. Forty of the wells are in the immediate vicinity of or are within Nevada Test Site, and the aquifer or aquitard sampled is known beyond a reasonable doubt. Many of these 40 wells were sampled 2 or more times. In several of the test holes drilled specifically for hydrologic data, water samples were obtained from more than one aquifer or from two or more depths within a single aquifer. The authors use water chemistry to (1) define parts of the boundary of the Ash Meadows ground-water basin, (2) determine the direction of ground-water movement in the lower carbonate aquifer in the basin, (3) estimate the magnitude of downward leakage of semiperched ground water from the Cenozoic rocks into the lower carbonate aquifer, and (4) speculate on the depth of circulation within the lower carbonate aquifer.

The chemical analyses used are chiefly from the following sources: Maxey and Jameson (1948), Clebsch and Barker (1960), J. E. Moore (1961), Malmberg and Eakin (1962), Walker and Eakin (1963), Schoff and Moore (1964), and Pistrang and Kunkel (1964). In addition, analyses for the Pahrump Valley were obtained from the files of the U.S. Geological Survey in Carson City, Nev. Post-1963 analyses of ground water by W. A. Beetem and his associates, though not yet published, are on file at the U.S. Geological Survey offices in Denver, Colo.

\section{PREVIOUS INTERPRETATION OF GROUND-WATER CHEMISTRY}

Schoff and Moore (1964) presented the following observations and conclusions on the regional flow of ground water at the Nevada Test Site:

1. They recognized three types of ground water at Nevada Test Site and vicinity: (a) sodium and potassium bicarbonate; (b) calcium and magnesium bicarbonate; and (c) mixed. The sodium and potassium bicarbonate type is found in tuff aquifers and aquitards, and in the valley-fill aquifer in Emigrant Valley, Yucca Flat, Frenchman Flat, and Jackass Flats. The calcium and magnesium bicarbonate type is found in Paleozoic carbonate aquifers, as well as in valleyfill aquifers that are composed chiefly of carbonaterock detritus. Schoff and Moore (1964) recognized such water only in southern Indian Springs Valley. They $(1964$, p. 62) defined mixed water as water having characteristics of both the preceding types. They believed that such water may have formed in one of three ways: (a) movement of water from tuffaceous into carbonate rocks (or alluvium with carbonate-rock detritus), followed by dissolution of carbonate minerals; (b) movement of water from carbonate rocks into tuff (or tuffaceous alluvium), followed by acquisition of sodium either by solution or by ion exchange of calcium for sodium; or (c) mixing of calcium and magnesium bicarbonate water with sodium and potassium bicarbonate water. They noted further that water of mixed chemical type is found in some of the carbonate 
rocks within the Nevada Test Site and that such water predominates in the Amargosa Desert.

2. From dissolved-solids content Schoff and Moore (1964, p. 56 and 57) concluded that appreciable ground water in the Cenozoic aquifers beneath Emigrant Valley is not moving into Cenozoic aquifers in Yucca Flat, becuase the dissolved-solids content of water in both valleys is similar. The average dissolved-solids content of water from the Amargosa Desert is "twice that for water in Indian Springs Valley and substantially greater than the dissolved solids in most water of the Test Site. The maximum for the Amargosa Desert is the greatest in the region. The dissolved solids point to the Amargosa Desert, therefore, as the destination to which ground water may be going, not as the place from which it comes."

3. From the sodium content Schoff and Moore (1964, p. $60)$ concluded that:

[a] The water in the Paleozoic carbonate rocks underlying the Test Site is in part recharged by percolation downward through tuff or through alluvium containing detrital tuff, or both. The water entering the carbonate rocks in this manner is generally a sodium potassium type, which when added to the calcium magnesium type already in the rocks yields a water of mixed chemical character.

[b] The water in the carbonate rocks of the Test Site may be moving toward the Amargosa Desert, where the water generally is of mixed chemical character, [has] a generous amount of sodium, and [is] more concentrated than [water] within the Test Site. Not all the water reaching the Amargosa Desert, however, need come from the Test Site.

[cl The water of Indian Spring Valley has had little opportunity for contact with tuff or tuffaceous alluvium, or with another rock material containing much soluble sodium. This water probably entered the rocks as recharge on the upper slopes of the Spring Mountains, which lie to the south. The mountains contain extensive outcrops of carbonate rocks, from which calcium and magnesium could be dissolved.

[d] The water in the carbonate rocks is not moving southward from the Test Site to Indian Spring Valley. If it did so, the waters of Indian Spring Valley would contain more sodium, and also would probably be higher in dissolved solids.

The cited observations and conclusions of Schoff and Moore (1964) generally appear sound.

Hunt, Robinson, Bowles, and Washburn (1966, p. B40) compared the chemistry of ground water at Ash Meadows with that at Furnace Creek Wash (in Death Valley) and with that in Pahrump Valley. They concluded that Pahrump Valley is the source of the spring discharge at Ash Meadows. They argued further that the chemical quality of the major springs in the Furnace Creek Wash area resembles that of water from Ash Meadows and that Pahrump Valley is also its source.

\section{HYDROCHEMICAL FACIES}

The chemical character of ground water is influenced by many variables. Several cited by Back (1966) include: (1) Chemical character of the water as it enters the zone of saturation; (2) distribution, solubility, and adsorption capacity of minerals in the rocks; (3) porosity and permeability of the rocks; and (4) the flow path of the water. The flow path introduces variables such as mixture of water from two sources, changes in pressure and temperature with depth, and rate of flow. Within geographically restricted areas, ground water from a single aquifer or related group of aquifers may have a relatively fixed chemical character imposed by the listed variables. This chemical character is referred to in some recent literature as hydrochemical facies (Back, 1966; Seaber, 1965).

Plate 3 shows regional patterns of hydrochemical facies at Nevada Test Site and vicinity. Pie diagrams represent the equivalents per million of major cations and anions. On plate 3 , Nevada Test Site and vicinity have been divided on the basis of geography, known hydrologic setting, and hydrochemical character. The several areas and the generalized chemical characteristics of their waters are summarized in table 8 . The median character of sampled ground water for each area is depicted graphically in figure 38 . Whereas space precluded plotting of pie diagrams for each available analysis on plate 3 , all representative analyses, except as noted hereafter, are included in the statistical summary in table 8. Plate 3 and table 8 confirm the three types (or facies) of water defined by Schoff and Moore (1964), suggest two other facies, and identify an area where three facies mix. Four of the five facies are defined in table 9. The calcium magnesium bicarbonate facies, which Schoff and Moore identified in southern Indian Springs Valley (area IB, pl. 3), also is found in southern Three Lakes Valley (IB), northwestern Las Vegas Valley (IB), and Pahrump Valley (IC), as well as within the Spring Mountains (IA). It is also found in Pahranagat Valley (ID), where prominent valley-level springs discharge from the lower carbonate aquifer. Water of this facies occurs in the cited areas in wells tapping either the lower carbonate aquifer or the valley-fill aquifer rich in carbonate-rock detritus; water from perched or valleylevel carbonate rock springs in these areas is also of this facies.

The sodium potassium bicarbonate facies, noted by Schoff and Moore (1964) for ground water from western Emigrant Valley (area IIB), Yucca Flat (IIC), Frenchman Flat (IID), and Jackass Flats (IIE), also is found in water beneath Pahute Mesa (IIF) and Oasis Valley (IIG), northwest and west of Nevada Test Site. This water is found in tuff, rhyolite, and valley-fill aquifers rich in volcanic detritus; rarely, as in well 84-67 


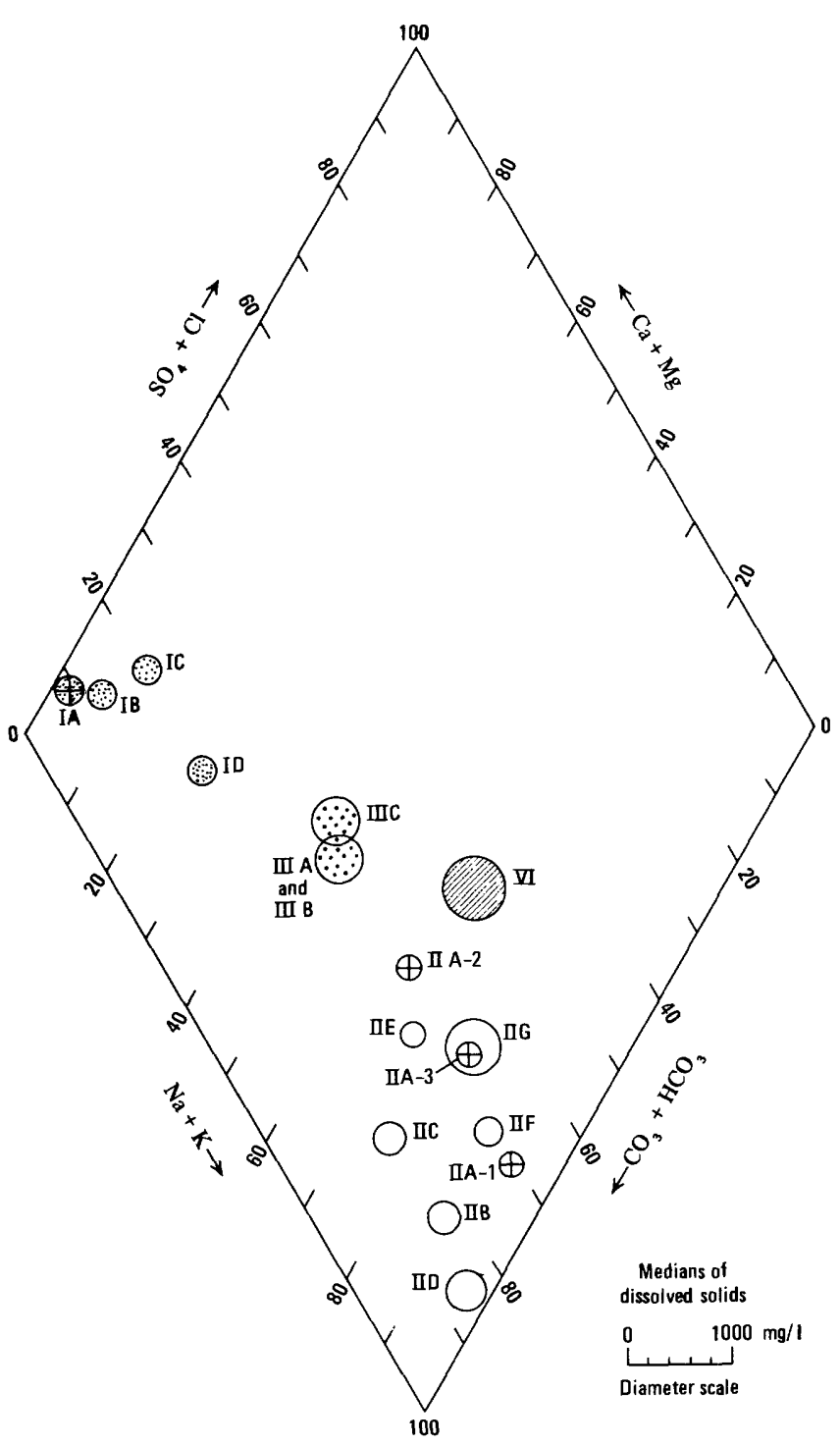

FIGURE 38. - Chemical types of the ground water at Nevada Test Site and vicinity. Roman numerals refer to map numbers and areas listed in table 8 and shown on pl. 3; circles with crosses represent populations of perched water; patterns in circles next to map numbers facilitate visual grouping of the hydrochemical facies.

(in central Yucca Flat), it is also found in thin carbonate strata within the upper clastic aquitard.

Water of mixed chemical character, noted by Schoff and Moore (1964) in the Nevada Test Site (area IIIC) and the east-central Amargosa Desert (IIIA and IIIB), is designated the calcium magnesium sodium bicarbonate facies in this report. This water occurs within the lower carbonate aquifer between Ash Meadows and eastern Nevada Test Site. As noted by Schoff and Moore (1964), water from two wells tapping Cenozoic rocks in Yucca Flat (well 83-68 tapping the valley-fill aquifer and well 81-67 tapping the bedded-tuff aquifer) also is of mixed character (pl. 3). The dissolved-solids content of water from these wells is, however, $100 \mathrm{mg} / \mathrm{l}$ (milligrams per liter) less than that of the mixed water in the lower carbonate aquifer. Schoff and Moore's explanation of the anomalous water in well 81-67 appears reasonable; namely, that water tapped by this well is derived from Paleozoic strata, which occur about 1 mile west of the well (pl. $2 B$ ). However, this explanation is not applicable to the anomalous water from well 83-68; nor, for that matter, is it consistent with the sodium potassium bicarbonate water from well 84-67, which taps thin carbonate strata within the upper clastic aquitard.

Two other facies are suggested by plate 3: a playa facies (area V), which appears restricted to the "wet" playas (playas from which ground water is discharged by evapotranspiration) or to shallow wells in discharge areas; and a sodium sulfate bicarbonate facies, which appears to be restricted to the springs in the Furnace Creek Wash-Nevares Springs area (area VI) and to a few wells in the west-central Amargosa Desert. The chemistry of the playa facies is highly variable, dependent in part on the depth of the sampling well; a formal definition of this facies is not attempted in this report.

Analyses of water from selected wells in western Pahrump and Stewart Valleys were excluded from the statistical summary presented in table 8 . These wells are less than 100 feet deep and are generally on or along the periphery of the playas in northwestern Pahrump and Stewart Valleys, where the water table is shallowest, less than 20 feet below the surface. Most of the excluded wells are less than 40 feet deep. The water from some of these wells is more highly mineralized than the water from most deeper wells in Pahrump Valley. Choice of the 100-foot depth limitation was arbitrary. Generally, the highest mineralization was found in wells drilled to depths of 35 feet or less on or along the playa in Stewart Valley. The generally higher mineralization of water from these shallow wells is probably due to accumulation of solutes in water within the fine-grained salt-incrusted sediments that characterize valley-fill deposits in the vicinity of wet playas. Ground water in such sediments in areas of upward movement of water is neither hydrologically nor chemically similar to that of the deeper wells tapping the valley-fill aquifer in Pahrump Valley. Water from the deeper wells is of the calcium magnesium bicarbonate facies (pl. 3), whereas water from many of the shallow wells belongs to the playa facies. Water of the playa facies is also found in shallow wells along the periphery of Alkali Flat at the south end of the Amargosa Desert (north of Eagle Mountain, fig. 34).

Along the margins of the study area, in Pahranagat Valley and at Furnace Creek Wash in Death Valley, only analyses from major springs discharging from the lower carbonate aquifer at valley level were used in the tabula- 
TABLE 8. - Chemical constituents of ground water [All constituents reported in milliequivalents

\begin{tabular}{|c|c|c|c|c|c|c|c|c|c|c|c|c|}
\hline \multirow{2}{*}{\multicolumn{2}{|c|}{ Map number and area (pl. 3) }} & \multirow{2}{*}{ Hydrogeologic setting } & \multirow{2}{*}{$\begin{array}{l}\text { Number of } \\
\text { samples }\end{array}$} & \multicolumn{3}{|c|}{$\mathrm{Ca}+\mathrm{Mg}$} & \multicolumn{3}{|c|}{$\mathrm{Na}+\mathrm{K}$} & \multicolumn{3}{|c|}{$\mathrm{HCO}_{: 1}+\mathrm{CO}_{1}$} \\
\hline & & & & Range & Median & Mean & Range & Median & Mean & Range & Median & Mean \\
\hline \multicolumn{13}{|c|}{ Calcium magnesium bicarbonate facies } \\
\hline IA & Spring Mountains ${ }^{2}$ & $\begin{array}{l}\text { Major recharge area; highest } \\
\text { parts underlain principally } \\
\text { by Paleozoic carbonate } \\
\text { rocks. Water sampled from } \\
\text { perched springs. }\end{array}$ & 4 & $4.6-5.5$ & 4.9 & 5.0 & $0.05-0.7$ & 0.10 & 0.3 & $4.4-5.5$ & 4.7 & 4.8 \\
\hline IB & $\begin{array}{l}\text { Northwest Las Vegas Valley; } \\
\text { southern Three Lakes } \\
\text { Valley; southern Indian } \\
\text { Springs Valley. }\end{array}$ & $\begin{array}{l}\text { Piedmont alluvial plain } \\
\text { bordering Spring Moun- } \\
\text { tains on the northeast. } \\
\text { Water sampled from both } \\
\text { valley-fill and lower car- } \\
\text { bonate aquifers. }\end{array}$ & 10 & $3.1-6.3$ & 4.0 & 4.2 & $.08-.71$ & .30 & .34 & $3.0-4.7$ & 3.7 & 3.7 \\
\hline IC & Pahrump Valley: & $\begin{array}{l}\text { Piedmont alluvial plain } \\
\text { bordering Spring Moun- } \\
\text { tains on the southwest. } \\
\text { Water s a mpled from } \\
\text { valley-fill aquifer only. }\end{array}$ & 26 & $3.2-12$ & 4.5 & 5.2 & $.22-2.0$ & $.57(25)$ & .86 & $3.3-8.5$ & 3.9 & 4.2 \\
\hline ID & Pahranagat Valley _- & $\begin{array}{l}\text { Major discharge area for } \\
\text { lower carbonate aquifer; } \\
\text { high-yield springs sampled. }\end{array}$ & 3 & $3.4-4.2$ & 4.1 & 3.9 & $1.1-1.6$ & 1.4 & 1.4 & $3.8-4.5$ & 4.3 & 4.2 \\
\hline \multicolumn{13}{|c|}{ Sodium potassium bicarbonate facies } \\
\hline IIA-1 & Rainier Mesa & $\begin{array}{l}\text { Minor recharge area; ground } \\
\text { water perched in tuff } \\
\text { aquitard sampled. }\end{array}$ & 24 & $0.01-1$ & .1 & .3 & $0.72-4.3$ & 1.4 & 1.7 & $0.79-2.3$ & $1.2(23)$ & 1.3 \\
\hline IIA-2 & $\begin{array}{l}\text { Hills west of Yucca and } \\
\text { Frenchman Flats. }\end{array}$ & $\begin{array}{l}\text { Minor recharge area; ground } \\
\text { water perched in tuff and } \\
\text { lava-flow aquitards } \\
\text { sampled. }\end{array}$ & 9 & $.16-2.4$ & .87 & .93 & $1.0-4.5$ & 1.7 & 1.9 & $.63-3.3$ & 1.6 & 1.8 \\
\hline IIA-3 & Hills west of Oasis Valley. & $\begin{array}{l}\text { Minor recharge area; ground } \\
\text { water perched in tuff } \\
\text { aquitard sampled. }\end{array}$ & 5 & $.48-1.4$ & .72 & .88 & $2.5-3.3$ & 2.8 & 2.8 & $1.9-2.5$ & 2.3 & 2.2 \\
\hline IIB & Emigrant Valley _- $\ldots---$ & $\begin{array}{l}\text { Hydraulically closed basin } \\
\text { with minor discharge to } \\
\text { east. Water sampled from } \\
\text { valley -fill and tuff } \\
\text { aquifers(?) and aquitards. }\end{array}$ & 3 & $.39-1.0$ & .42 & .60 & $2.5-4.0$ & 3.2 & 3.2 & $2.8-3.6$ & 2.9 & 3.0 \\
\hline IIC & Yucca Flat & $\begin{array}{l}\text { Ground water semiperched in } \\
\text { valley-fill and tuff aquifers } \\
\text { and aquitards above un- } \\
\text { derlying lower carbonate } \\
\text { aquifer; only Cenozoic } \\
\text { strata sampled. }\end{array}$ & 5 & $.08-2.0$ & 1.1 & 1.0 & $1.9-4.0$ & 3.4 & 3.1 & $2.5-3.4$ & $3.2(4)$ & 3.1 \\
\hline IID & Frenchman Flat & $\begin{array}{l}\text { Ground water semiperched in } \\
\text { valley-fill and tuff aquifers } \\
\text { and aquitards above un- } \\
\text { derlying lower carbonate } \\
\text { aquifer; only Cenozoic } \\
\text { strata sampled. }\end{array}$ & 3 & $.15-.52$ & .16 & .28 & $4.5-7.2$ & 5.7 & 5.8 & $2.9-6.3$ & 4.9 & 4.7 \\
\hline IIE & Jackass Flats & $\begin{array}{l}\text { Ground water in welded-tuff } \\
\text { aquifer; water is discharged } \\
\text { southward into Amargosa } \\
\text { Desert. }\end{array}$ & 3 & $.88-5.3$ & .88 & 2.4 & $1.9-7.0$ & 2.2 & 3.7 & $1.7-2.1$ & 2.0 & 1.9 \\
\hline IIF & Pahute Mesa _. & $\begin{array}{l}\text { Ground water in tuff and } \\
\text { rhyolite aquifers and } \\
\text { aquitards in Silent Canyon } \\
\text { caldera. }\end{array}$ & 10 & $.02-2$ & .4 & .7 & $1.3-6.5$ & 2.8 & 3.5 & $1.1-5.2$ & 2.2 & 2.3 \\
\hline IIG & Oasis Valley _- & $\begin{array}{l}\text { Major discharge area for } \\
\text { water in welded-tuff } \\
\text { aquifer of Oasis Val- } \\
\text { ley-Fortymile Canyon } \\
\text { ground-water basin. }\end{array}$ & 17 & $.28-3.8$ & 1.4 & 1.5 & $3.8-9.8$ & 5.5 & 6.1 & $2.6-8.7$ & 4.5 & 4.7 \\
\hline \multicolumn{13}{|c|}{ Calcium magnesium sedium bicarbonate facies } \\
\hline IIIA & Ash Meadows _ & $\begin{array}{l}\text { Principal discharge area for } \\
\text { water in lower carbonate } \\
\text { aquifer of Ash Meadows } \\
\text { ground-water basin. }\end{array}$ & 6 & $3.5-4.2$ & 4.0 & 3.9 & $3.1-4.8$ & 3.8 & 3.8 & $5.0-5.2$ & 5.0 & 5.0 \\
\hline IIIB & $\begin{array}{l}\text { East-central Amargosa } \\
\text { Desert. }\end{array}$ & $\begin{array}{l}\text { Area of upward leakage of } \\
\text { water from lower carbonate } \\
\text { aquifer into valley-fill } \\
\text { aquifer. }\end{array}$ & 3 & $3.2-3.6$ & 3.5 & 3.4 & $2.8-5.6$ & 3.3 & 3.9 & $3.4-5.7$ & 4.5 & 4.5 \\
\hline $\begin{array}{r}\text { IIIC } \\
\text { (i) }\end{array}$ & Eastern Nevada Test Site ${ }^{4}$. & $\begin{array}{l}\text { Area of interbasin movement } \\
\text { of ground water through the } \\
\text { lower carbonate aquifer. }\end{array}$ & 6 & $3.1-5.9$ & 4.2 & 4.3 & $1.7-5.9$ & 3.6 & 3.7 & $4.2-8.6$ & 5.0 & 5.5 \\
\hline \multicolumn{13}{|c|}{ Sodium sulfate bicarbonate facies } \\
\hline VI & $\begin{array}{l}\text { Furnace Creek Wash- } \\
\text { Nevares Springs area. } \\
\text { Death Valley. }\end{array}$ & $\begin{array}{l}\text { Major discharge area for } \\
\text { water in lower carbonate } \\
\text { aquifer. }\end{array}$ & 3 & $3.3-3.9$ & 3.4 & 3.5 & $6.3-7.2$ & 7.0 & 6.9 & $5.2-5.8$ & 5.7 & 5.6 \\
\hline
\end{tabular}

'Number in parentheses after select constituents indicates number of samples when less than shown in number of samples column.

'Excludes Grapevine Spring, in mineralized zone in northwest Spring Mountains. 作 cipally along periphery of playas. 
in the Nevada Test Site and vicinity per liter, except as indicated]

\begin{tabular}{|c|c|c|c|c|c|c|c|c|c|c|c|}
\hline \multicolumn{3}{|c|}{$\mathrm{SO}_{4}+\mathrm{Cl}$} & \multirow{2}{*}{$\frac{\mathrm{Ca}+\mathrm{Mg}}{\underset{\times}{\mathrm{Ca}+\mathrm{Mg}+\mathrm{Na}+\mathrm{K}}}$} & \multirow{2}{*}{$\frac{\mathrm{HCO}_{3}+\mathrm{CO}_{3}}{\underset{\mathrm{HCO}_{3}+\mathrm{CO}_{i}+\widehat{\mathrm{SO}}_{+}+\mathrm{Cl}}{\times 100 \text { (percent) }}}$} & \multicolumn{3}{|c|}{$\mathrm{SiO}_{2}(\mathrm{mg} / \mathrm{l})$} & \multicolumn{3}{|c|}{$\begin{array}{c}\text { Dissolved solids }(\mathrm{mg} / \mathrm{l}) \\
\left.\text { (Residue on evaporation at } 180^{\circ} \mathrm{C}\right) \\
\end{array}$} & \multirow{2}{*}{ Data sources } \\
\hline Range & Median & Mean & & & Range & Median & Mean & Range & Median & Mean & \\
\hline \multicolumn{12}{|c|}{ Calcium magnesium bicarbonate facies - Continued } \\
\hline $0.15-0.60$ & 0.38 & 0.38 & 98 & 92 & $6.5-33$ & 8.4 & 14 & $232-351$ & 248 & 270 & $\begin{array}{l}\text { Maxey and Jameson (1948); } \\
\text { U.S. Geol. Survey files, } \\
\text { Denver, Colo. }\end{array}$ \\
\hline \multirow[t]{2}{*}{$.40-2.7$} & 48 & .77 & 93 & 88 & $6.6-25$ & $15(9)$ & 15 & $200-340$ & 216 & 235 & Do. \\
\hline & 1.1 & 1.8 & 89 & 80 & $8-38$ & $20(21)$ & 20 & $208-822$ & $290(25)$ & 354 & $\begin{array}{l}\text { Maxey and Jameson (1948); } \\
\text { U.S. Geol. Survey files, } \\
\text { Carson City, Nev. }\end{array}$ \\
\hline $.79-1.1$ & 1.0 & 1.0 & 75 & 81 & $31-33$ & 31 & 32 & $\ldots$ & $277(1)$ & --- & Eakin (1963) \\
\hline \multicolumn{12}{|c|}{ Sodium potassium bicarbonate facies - Continued } \\
\hline $0.23-1.1$ & $0.48(23)$ & 0.50 & 7 & 71 & $34-126$ & 52 & 54 & $91-424$ & 192 & 220 & Clebsch and Barker (1960). \\
\hline $.40-1.9$ & .67 & .90 & 35 & 70 & $32-66$ & 50 & 51 & $166-330$ & 190 & 228 & $\begin{array}{l}\text { J. E. Moore (1961); Schoff } \\
\text { and Moore (1964). }\end{array}$ \\
\hline $.91-1.8$ & 1.1 & 1.2 & 20 & 68 & $52-55$ & $54(2)$ & 54 & $171-266$ & 224 & 217 & Malmberg and Eakin (1962). \\
\hline $.58-.66$ & .62 & .62 & 11 & 83 & $77-86$ & 85 & 83 & $268-310$ & 279 & 286 & $\begin{array}{l}\text { J. E. Moore (1961); Schoff } \\
\text { and Moore (1964); U.S. } \\
\text { Geol. Survey files, Denver, } \\
\text { Colo. }\end{array}$ \\
\hline $.50-2.3$ & .62 & 1.1 & 24 & 84 & $61-107$ & 74 & 78 & $274-370$ & 296 & 317 & Do. \\
\hline $.77-1.8$ & .83 & 1.1 & 3 & 86 & $55-60$ & 56 & 57 & $337-451$ & 369 & 386 & Do. \\
\hline $.68-10$ & .72 & 4.1 & 29 & 74 & $55-67$ & 58 & 60 & $211-886$ & 236 & 444 & Do. \\
\hline $.17-6.0$ & .94 & 1.7 & 10 & 71 & $41-50$ & 44 & 45 & $117-583$ & 242 & 297 & $\begin{array}{l}\text { U.S. Geol. Survey files, } \\
\text { Denver, Colo. }\end{array}$ \\
\hline $1.6-5.9$ & 2.2 & 2.7 & 20 & 67 & $54-68$ & $65(3)$ & 62 & $330-1,071$ & 532 & 580 & Malmberg and Eakin (1962). \\
\hline
\end{tabular}

\begin{tabular}{|c|c|c|c|c|c|c|c|c|c|c|c|}
\hline \multicolumn{12}{|c|}{ Calcium magnesium sodium bicarbonate facies - Continued } \\
\hline $2.2-3.1$ & 2.2 & 2.5 & 51 & 70 & $20-33$ & 22 & 24 & $413-500$ & 420 & 441 & $\begin{array}{l}\text { Walker and Eakin (1963); } \\
\text { Schoff and Moore (1964); } \\
\text { U.S. Geol. Survey files, } \\
\text { Denver. Colo. }\end{array}$ \\
\hline $1.3-5.0$ & 1.9 & 2.7 & 51 & 70 & $18-20$ & 18 & 19 & $342-548$ & 372 & 421 & Do. \\
\hline $1.6-4.1$ & 2.4 & 2.4 & 54 & 68 & $13-40$ & 27 & 26 & $323-606$ & 437 & 455 & $\begin{array}{l}\text { J. E. Moore (1961); Schoff and } \\
\text { Monre (1964): U.S. Geol. } \\
\text { Survey Files, Denver, Colo. }\end{array}$ \\
\hline \multicolumn{12}{|c|}{ Sodium sulfate bicarbonate facies - Continued } \\
\hline 4.5-4.6 & 4.6 & 4.6 & 32 & 56 & $\ldots$ & $25(1$ & & $616-716$ & 625 & 652 & Pistrang and Kunkel (1964). \\
\hline
\end{tabular}

Excludes 3 wells tapping the lower carbonate aquifer in northwestern Yucca Flat. The dissolved-solids content of 2 of those wells $(87-62$ and $88-66)$ is abnormally low. This property and the hydrogeologic setting of the wells suggest only local recharge; the third well hydrogeologic setting of these areas precludes meaningful statistical summary; see text discussion. 
tion. Chemical quality of discharge from the major springs should be an average of the chemical quality of water in the lower carbonate aquifer, whereas water from low-yield springs (for example, Daylight and Keane Wonder Springs in the Funeral Mountains) or from wells of unknown construction may represent local recharge, recycled water, or water from several aquifers.

TABLE 9. - Classification of hydrochemical facies at the Nevada Test Site and vicinity

\begin{tabular}{lcccc}
\hline & \multicolumn{4}{c}{$\begin{array}{c}\text { Percentage range of milliequivalents per } \\
\text { liter of major constituents }\end{array}$} \\
\cline { 2 - 5 } Hydrochemical facies & $\mathrm{Ca}+\mathrm{Mg}$ & $\mathrm{Na}+\mathrm{K}$ & $\mathrm{HCO}_{3}+\mathrm{CO}_{3}$ & $\mathrm{SO}_{4}+\mathrm{Cl}$ \\
\hline $\begin{array}{l}\text { Calcium magnesium } \\
\text { bicarbonate }\end{array}$ & $75-100$ & $0-25$ & $80-90$ & $10-20$ \\
$\begin{array}{l}\text { Sodium potassium } \\
\text { bicarbonate }\end{array}$ & $5-35$ & $65-95$ & $65-85$ & $15-35$ \\
$\begin{array}{l}\text { Calcium magnesium sodium } \\
\text { bicarbonate }\end{array}$ & $50-55$ & $45-50$ & 70 & 30 \\
$\begin{array}{l}\text { Sodium sulfate } \\
\text { bicarbonate }\end{array}$ & 30 & 70 & 60 & 40 \\
\hline iMinor constituents such & & & & \\
\end{tabular}

Minor constituents such as $\mathrm{Li}, \mathrm{Sr}, \mathrm{NO}_{3}$, and $\mathrm{F}$ are not included in cation-anion percentag

\section{VARIATIONS OF DISSOLVED-SOLIDS CONTENT WITH DEPTH IN THE LOWER CARBONATE AQUIFER}

Qualitative information on the vertical variation of dissolved solids in the lower carbonate aquifer is derived from several wells at Nevada Test Site, three oil-test wells drilled northeast of Nevada Test Site, and a comparison of the water from wells at Nevada Test Site with discharge from the springs at Ash Meadows.

Well 89-68 was drilled to a depth of 6,000 feet in northern Yucca Flat (pl. 2). Between 1,773 and 5,290 feet, the bore penetrated the lower clastic aquitard (Stirling Quartzite, 1,773-2,360 ft; Johnnie Formation, 2,360-5,290 ft; and the Noonday(?) Dolomite, $5,290-6,000 \mathrm{ft}$ ). A major permeable fault zone was found between the Johnnie Formation and the Noonday(?) Dolomite. Analyses of water samples from two intervals $(1,785-1,940$ and 1,785-6,000 ft) are given in table 10 . The two analyses indicate little change in chemical quality with depth. The upper interval was sampled when the well was 1,940 feet deep. The drill-stem test data indicate that most of the water of the second sample came from depths greater than 2,170 feet and that a significant quantity of it, probably more than half, may have come from the permeable fault zone at a depth of about 5,290 feet. Heads measured during drill-stem testing indicate that the second sample does not reflect water that moved downward along the bore from upper to lower zone during or after drilling. The analyses suggest that the water quality in the lower clastic aquitard is relatively uniform to depths of several thousand feet. The absence of a significant change in the chemistry of water within the lower clastic aquitard suggests that the water in the lower carbonate aquifer may also be relatively uniform chemically to depths of several thousand feet.
TABLE 10. - Chemical analyses of water from test wells 89-68 and 67-68, Yucca Flat and Mercury Valley, Nye County

[Values for chemical constituents are in milligrams per liter. Analyses by U.S. Geol. Survey, Denver, Colo]

\begin{tabular}{|c|c|c|c|c|}
\hline \multirow[b]{2}{*}{ Depth interval (ft) } & \multicolumn{2}{|c|}{ Well 89-68 } & \multicolumn{2}{|c|}{ Well 67-68 } \\
\hline & $1,785-1,940$ & $1,785-6,000$ & $786-1,050$ & $1,333-1,946$ \\
\hline $\begin{array}{l}\text { Silica }\left(\mathrm{SiO}_{2}\right) \\
\text { Calcium }(\mathrm{Ca}) \\
\text { Magnesium }(\mathrm{Mg}) \\
\text { Sodium }(\mathrm{Na}) \\
\text { Potassium }(\mathrm{K}) \\
\text { Bicarbonate }\left(\mathrm{HCO}_{3}\right) \\
\text { Carbonate }\left(\mathrm{CO}_{3}\right) \\
\text { Sulfate }\left(\mathrm{SO}_{4}\right) \\
\text { Chloride }(\mathrm{Cl})\end{array}$ & $\begin{array}{r}8.5 \\
45 \\
11 \\
98 \\
16 \\
357 \\
0 \\
65 \\
17\end{array}$ & $\begin{array}{r}17 \\
41 \\
13 \\
96 \\
15 \\
384 \\
0 \\
0 \\
54 \\
11\end{array}$ & $\begin{array}{c}20 \\
46 \\
21 \\
38 \\
4.9 \\
254 \\
0 \\
58 \\
17\end{array}$ & $\begin{array}{c}21 \\
47 \\
21 \\
37 \\
5.2 \\
256 \\
0 \\
53 \\
16\end{array}$ \\
\hline $\begin{array}{l}\text { Specific conductance } \\
\left(\mu \text { mhos per } \mathrm{cm} \text { at } 25^{\circ} \mathrm{C}\right) \\
\mathrm{pH}\end{array}$ & $\begin{array}{l}715 \\
7.7\end{array}$ & $\begin{array}{c}720 \\
7.8\end{array}$ & $\begin{array}{c}483 \\
7.5\end{array}$ & $\begin{array}{c}554 \\
7.1\end{array}$ \\
\hline
\end{tabular}

Test hole 67-68 was drilled to a depth of 1,946 feet in southern Mercury Valley (fig. 33). In the zone of saturation, carbonate rocks of the Nopah Formation (table 1) are between 786 and 1,168 feet, the Dunderberg Shale Member of the Nopah Formation between 1,168 and 1,333 feet, and the carbonate rocks of the Bonanza King (?) Formation between 1,333 and 1,946 feet. Through use of two strings of cemented casing and packers, the Nopah Formation and the Bonanza King (?) Formation were test pumped separately. At the conclusion of each test, a water sample was collected and analyzed. The results of these analyses are shown in table 10. Drill-stem tests of the Nopah Formation indicated that the sample for this formation actually came from the interval $786-1,050$ feet. The drill-stem tests also indicated that the head in the Bonanza King (?) Formation was possibly as much as 4 feet higher than that in the upper aquifer.

A comparison of the chemical analyses of the water from the Nopah and Bonanza King(?) Formations indicates that the water in the two formations is practically identical. The near identical nature of the chemical quality of water from both aquifers may reflect natural upward crossflow through the Dunderberg Shale Member, which separates the two carbonate aquifers at the well site. Such crossflow is possible because of the 4foot head differential that may exist and because the Dunderberg, a thin clastic unit, is rarely continuous areally, owing to normal faulting and its tendency to be pinched out along major faults and tight folds. If crossflow in the region of well $67-68$ is upward and is principally responsible for the similarity in water chemistry noted for the two sampled intervals, then water of relatively low mineralization probably occurs in the lower carbonate aquifer at depths even greater than that penetrated by the well.

Specific conductance of water swabbed from two other test holes, wells 88-66 in Yucca Flat (pl. 2) and 66-75 (fig. 33) in southern Indian Springs Valley, suggests no increase in dissolved-solids content in the upper 800 feet of the lower carbonate aquifer. However, these data, ob- 
tained from additive drill-stem tests, are not as reliable as the data reported for wells $89-68$ and $67-68$.

Data from three deep oil tests in White Pine County in east-central Nevada indicate that rocks stratigraphically equivalent to the lower and upper carbonate aquifers contain water of low dissolved-solids content to depths as great as 10,000 feet. McJannett and Clark (1960, p. 248-250) summarized the results of drill-stem tests of three oil-test wells in White Pine County. In one well (16N/56-31), the Lone Mountain Dolomite (Silurian) reportedly contained fresh water in the depth interval 9,405-9,431 feet. A second well (15N/59-17), tested the Chainman Shale (Mississippian), the Joana Limestone (Mississippian), and the Nevada Formation (Devonian). Shaly limestone of the Chainman Shale reportedly contained either fresh water or drilling fluid in the interval $3,770-4,053$ feet. The top 39 feet of the Joana Limestone reportedly includes cavernous zones ranging from 2 to 9 feet in thickness, into which circulation was repeatedly lost. A drill-stem test of the cavernous interval, from 4,065 to 4,098 feet, reportedly recovered 1,890 feet of fresh water. Drill-stem tests of the Nevada Formation were made in the intervals $4,437-4,865,4,867-5,020$, and 5,023-5,117 feet; each zone reportedly yielded fresh water containing only 1 grain per gallon (or $17 \mathrm{mg} / \mathrm{l}$ ) of chloride (McJannett and Clark, 1960, p. 250). By comparison, the chloride content of water from the lower carbonate aquifer at Nevada Test Site and vicinity is 15-30 $\mathrm{mg} / \mathrm{l}$. In a third oil-test well (20N/60-32), nine drill-stem tests were made of Permian carbonate rocks in the interval 4,000-8,600 feet; only drilling fluid or fresh water was reportedly recovered during the tests.

A comparison of the spring water at Ash Meadows with that within the lower carbonate aquifer beneath Nevada Test Site also suggests that the chemicalconstituent content in the lower carbonate aquifer does not vary markedly with depth. Data in table 8 and in figure 38 indicate that the chemical quality of the water within the lower carbonate aquifer beneath Nevada Test Site (area IIIC) is remarkably similar to that of the water discharging from the major springs at Ash Meadows (area IIIA).

The principal source of spring discharge at Ash Meadows is probably ground water moving southwestward within the lower carbonate aquifer (pl. 1); the chemical similarity between the springflow and the waters of area IIIC certainly does not contradict this assumption. In fact, Schoff and Moore (1964) considered it as proof of the southwestward movement of ground water. The samples of area IIIC represent only the upper 1,000 feet of the lower carbonate aquifer, which locally is several thousand feet thick. The chemical character of Ash Meadows springs, on the other hand, must represent, by virtue of the large discharge and its structural control, a chemical integration of water from the entire thickness of the lower carbonate aquifer within the Ash Meadows ground-water basin. Hence, the chemical similarity suggests that dissolved-solids content does not change significantly with depth in the carbonate aquifer at Nevada Test Site and vicinity. An alternate explanation is that water quality may deteriorate with depth but that such deterioration is not reflected at Ash Meadows because of an accompanying reduction in fracture transmissibility of the lower carbonate aquifer with depth.

In summary, chemical data from four wells at Nevada Test Site and three deep oil tests in east-central Nevada, as well as a comparison of the chemical quality of spring water at Ash Meadows with that of water in the lower carbonate aquifer beneath Nevada Test Site and vicinity, indicate no significant increase in the dissolvedsolids content of water in the lower carbonate aquifer to depths of several thousand feet. ${ }^{3}$

\section{SOURCES OF SODIUM AND SULFATE IONS IN WATER OF THE LOWER CARBONATE AQUIFER}

Of the five hydrochemical facies, the calcium magnesium sodium bicarbonate facies is of major importance for mapping the movement of ground water in the Ash Meadows basin. The origin of this facies, as suggested by the sodium and sulfate content of ground water, is discussed in this chapter, and the use of the facies for determination of the origin of the Ash Meadows spring discharge is the subject of the next chapter.

Ground water within the lower carbonate aquifer beneath Nevada Test Site (area IIIC of table 8) and at Ash Meadows (area IIIA) differs significantly from water in the lower carbonate aquifer elsewhere in the study area. The principal difference is in the milliequivalents per liter (meq/l) of sodium plus potassium and of sulfate plus chloride. For the water in the lower carbonate aquifer northeast (area ID) and southeast (areas IA, IB, and IC) of Nevada Test Site (pl. 3; table 8), median values of sodium and potassium range from 0.1 to $1.4 \mathrm{meq} / \mathrm{l}$; whereas for water in the same aquifer beneath Ash Meadows and at Nevada Test Site (areas IIIA and IIIC), median values range from 3.6 to $3.8 \mathrm{meq} / \mathrm{l}$. The sulfate and chloride content of water in the lower carbonate aquifer southeast and northeast of Nevada Test Site ranges from 0.38 to $1.1 \mathrm{meq} / \mathrm{l}$; whereas beneath Ash Meadows and at Nevada Test Site, it ranges from 2.2 to $2.4 \mathrm{meq} / \mathrm{l}$. Similarly, the median dissolved-solids content ranges from 216 to $290 \mathrm{mg} / \mathrm{l}$ southeast and northeast of the site and from 420 to $437 \mathrm{mg} / \mathrm{l}$ beneath the site and at Ash Meadows. These variations are summarized in table 8.

'In the Las Vegas area and elsewhere in eastern Nevada, miogeosynclinal carbonate rocks (chiefly of Permian age) are interbedded with sedimentary gypsum or with clastic rocks containing detrital gypsum. In such areas, ground water in the Paleozoic carbonate aquifers may be highly mineralized (even at relatively shallow depths) in comparison with water in the gypsum-free Paleozoic carbonate rocks of the Ash Meadows ground-water basin. 
In the ion pairs (sodium plus potassium and sulfate plus chloride), sodium and sulfate are the principal ions. Potassium typically ranges from only 5 to 10 percent of the sum of sodium and potassium, whereas chloride typically ranges from 25 to 35 percent of the sum of sulfate and chloride. These percentages persist in all the areas in table 8.

The discussion that follows pertains in general only to sodium and sulfate ions. For convenience, the median values of the ion pairs sodium plus potassium and sulfate plus chloride for areas IA-IIIC (table 8) are taken as representative of sodium and sulfate, respectively. This shortcut seems justifiable because of the cited dominance of $\mathrm{Na}$ (90-95 percent) and $\mathrm{SO}_{4}(65-75$ percent) in the ion pairs for each group and the magnitude of the difference, between select areas. The sodium or the sulfate content of water from individually cited wells, on the other hand, will always pertain only to a single cation or anion.

\section{SODIUM}

The principal source of sodium ions within the lower carbonate aquifer beneath Nevada Test Site is ground water that originated in or passed through the Tertiary tuff aquifers and aquitards.

Median values of sodium for ground water in areas IA, IB, and IC (pl. 3; table 8) are, respectively, 0.1, 0.3, and $0.6 \mathrm{meq} / \mathrm{l}$ (roughly $2-15 \mathrm{mg} / \mathrm{l}$ ). The water from these areas was derived directly from either the lower carbonate aquifer or the valley-fill aquifer rich in carbonate-rock detritus. The low sodium content is expected of water from these aquifers in the areas represented by areas IA to IC because minerals (for example, plagioclase feldspar and halite and other evaporites) that normally contribute sodium to ground water are either absent or sparse in the aquifers of these areas.

The median value of sodium for ground water in areas IIB to IIG ranges from 2.2 to $5.7 \mathrm{meq} / \mathrm{l}$ (roughly 50-130 $\mathrm{mg} / \mathrm{l})$. This water comes directly from either Tertiary tuff aquifers and aquitards of rhyolitic or quartz latitic composition or valley fill rich in tuff detritus. Sodium comes chiefly from the alteration of rhyolitic glass (shards and pumice), plagioclase feldspar (this and cristobalite are the chief devitrification products of rhyolitic glass), and perhaps zeolite minerals, which together constitute the bulk of these volcanic rocks. Leaching of sodium from glassy and crystalline tuffs at the Nevada Test Site was discussed at length by Lipman (1965) and Hoover (1968).

The low sodium content of water from the lower carbonate and valley-fill aquifers bordering the Spring Mountains contrasts markedly with the higher sodium content of ground water derived from the volcanic terrane of Nevada Test Site and vicinity. This contrast and the absence of any obvious important source of sodium in the carbonate rocks beneath or flanking Nevada Test Site suggest that much, probably most, of the sodium within the lower carbonate aquifer beneath Nevada Test Site (area IIIC) comes from ground water that has moved through tuffaceous aquifers and aquitards of rhyolitic or quartz latitic composition.

Sodium ions may enter the lower carbonate aquifer beneath Nevada Test Site in three ways. Some may originate in semiperched ground water in the tuff aquitard and enter the carbonate aquifer by downward crossflow in Yucca and Frenchman Flats and possibly also in the valleys east of Nevada Test Site (northern Indian Springs, northern Three Lakes, eastern Emigrant, and Desert Valleys). A second mechanism involves the movement of ground water upward from the lower carbonate aquifer into the tuff aquitard and then back down into the carbonate aquifer. Upward movement might occur, for example, in the vicinity of ground-water barriers within the carbonate aquifer. Once the water enters the tuff aquitard, sodium might be picked up by the ion exchange of calcium (in the carbonate-aquifer water) for sodium during contact of the water with the zeolitic and clayey minerals common within the aquitard. A third source of some (possibly one-third) of the sodium is importation, through the carbonate aquifer, from the region northeast of Nevada Test Site, mostly from Pahranagat Valley (area ID). The water emerging from the lower carbonate aquifer in Pahranagat Valley contains about five times as much sodium as that in area IB - namely in southern Indian Springs, southern Three Lakes, and northwest Las Vegas Valleys - but this amount of sodium is only about one-third that in the lower carbonate aquifer at Nevada Test Site (area IIIC) or at Ash Meadows (area IIIA). The high sodium content of the water from the upper carbonate aquifer in Pahranagat Valley is not unexpected. As in the Nevada Test Site area and in much of the area between Pahranagat Valley and Nevada Test Site, the Paleozoic strata in the ridges flanking Pahranagat Valley and surrounding valleys are commonly overlain by rhyolitic volcanic rocks, chiefly ash-flow tuffs and associated tuffaceous sedimentary rocks. Therefore, these rocks probably also occur locally within the zone of saturation and probably contribute sodium to the lower carbonate aquifer in areas of downward crossflow.

Of the three possible sources, the second appears least likely for two reasons. First, the zeolitized and clayey tuff aquitard at the base of the Tertiary strata both at and east of Nevada Test Site would tend to retard upward crossflow from the lower carbonate aquifer into the Tertiary rocks and also the return flow. Second, table 8 and figure 39 show no apparent reduction in calcium and magnesium content between areas IB or ID and areas IIIC and IIIA; such a reduction would be expected if ion 


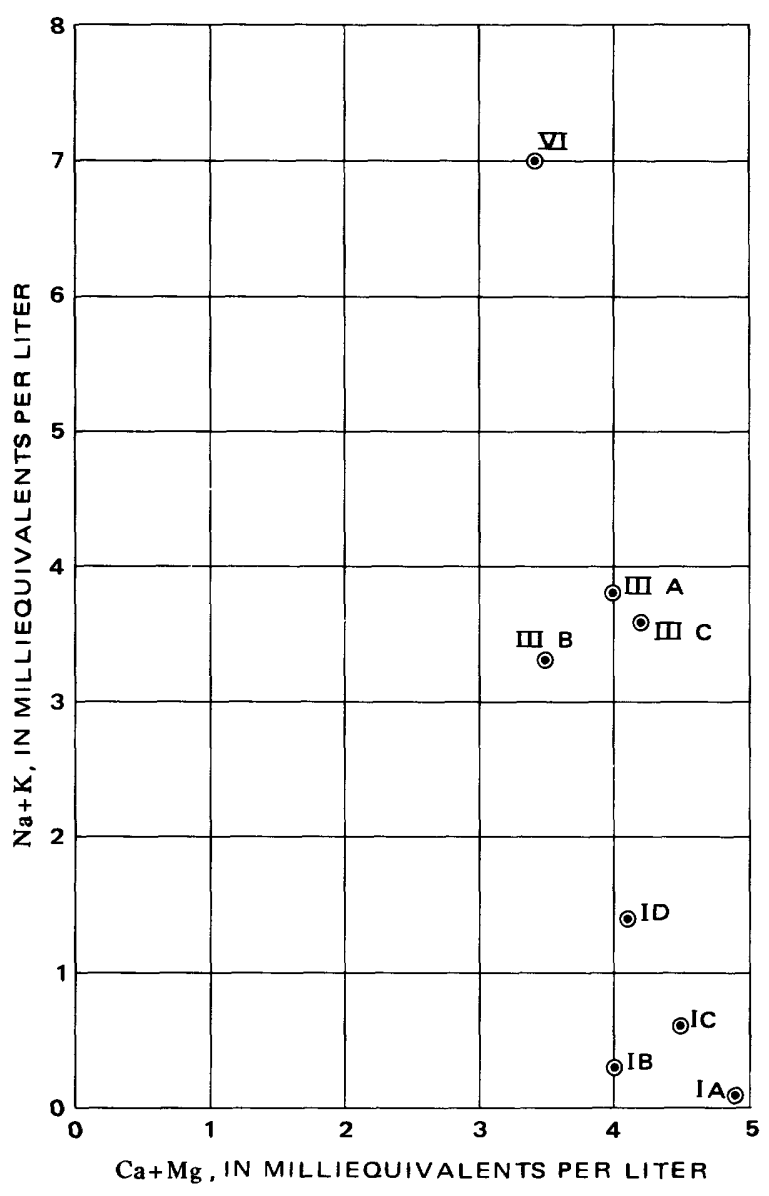

FiguRE 39. - Regional variations in $\mathrm{Na}+\mathrm{K}$ and $\mathrm{Ca}+\mathrm{Mg}$ within the lower carbonate aquifer. Roman numerals refer to map numbers and areas listed in table 8; median values are from the same table.

exchange were a significant factor in the pickup of sodium.

Although ground water within Tertiary aquifers and aquitards is probably a logical principal source for the sodium in water within the lower carbonate aquifer, a major problem remains. The sodium content of water in the carbonate rocks beneath Nevada Test Site (area IIIC) is slightly greater than that of water in the Tertiary rocks of Emigrant Valley (area IIB) and Yucca Flat (area IIC) and in the lower carbonate aquifer in Pahranagat Valley (area ID). Only the sodium content of ground water from the Tertiary and Quaternary aquifers of Frenchman Flat (area IID) is greater than that of water in the carbonate rocks. This indicates (1) still another source of sodium in addition to those outlined, (2) that downward leakage of water from Cenozoic rock in Frenchman Flat and perhaps other valleys constitutes a significant part of the Ash Meadows discharge (an assumption not supported by hydraulic data; see section "Intrabasin Movement,") or (3) that the sodium content of ground water in the Tertiary rocks increases markedly with depth or with stratum tapped. Evidence presented in the section on sulfate suggests that the sodium content of the ground water in the basal strata of the tuff aquitard, in the southern part of Nevada Test Site, is, at least locally, significantly greater than that of water sampled from the upper part of the zone of saturation in areas IIB, IIC, and IID.

Because the chemical quality of water in the lower carbonate aquifer in eastern Frenchman Flat (well 75-73) is almost identical with that of water at Ash Meadows (pl. 3 ; table 8 ), most of the sodium may have entered the lower carbonate aquifer (from the overlying tuff aquitard) principally in the valleys east or northeast of Frenchman Flat (namely, northern Indian Springs, northern Three Lakes, eastern Emigrant, and Desert Valleys). By analogy with hydrologic conditions in Yucca and Frenchman Flats, such downward leakage is possible in the cited valleys for reasons outlined in the section "Intrabasin Movement."

\section{SULFATE}

The increase in sulfate content of water in the lower carbonate aquifer between areas northeast and southeast of Nevada Test Site and the Nevada Test Site-Ash Meadows area is significant, although it not as marked as the increase in sodium content. (See table 8.) The sulfate content of water in the carbonate aquifers increases 120 percent between Pahranagat Valley (area ID) and Ash Meadows (table 8) and about 360 percent between the northeast flank of the Spring Mountains (area IB) and Ash Meadows. Moreover, the sulfate content within the lower carbonate aquifer beneath Nevada Test Site and Ash Meadows is three to four times that within Cenozoic aquifers or aquitards sampled in Emigrant Valley, Yucca Flat, and Frenchman Flat (areas IIB, IIC, and IID) (table 8). Three sources of sulfate ion are possible: (1) sulfide and sulfate minerals in granitic stocks, altered carbonate rocks, and altered volcanic rocks; (2) evaporite deposits within the Paleozoic carbonate strata; and (3) evaporite deposits within the basal Tertiary volcanic(?) strata in areas of downward crossflow.

Granitic stocks and altered carbonate and volcanic rocks occur locally within Nevada Test Site and may also occur within the zone of saturation east of Nevada Test Site. Oxidation of sulfide minerals such as pyrite or possible solution of sulfate minerals such as alunite $\mathrm{KAl}_{3}(\mathrm{OH})_{6}\left(\mathrm{SO}_{4}\right)_{2}$ - might serve as a source of sulfate ions. For example, in ground water perched in the Climax stock in northern Yucca Flat, sulfate content (exclusive of chloride) ranges from about 7 to $21 \mathrm{meq} / \mathrm{l}$ (Walker, 1962). The high sulfate is presumably due to oxidation of pyrite, which is common along fractures in the rock. Similarly, the high sulfate content (about 9 meq/l) of water from well 74-61, in central Jackass Flats, 
may be due to movement of ground water through rocks similar to those exposed in the Calico Hills, 5 miles north of the well. The Calico Hills consist of hydrothermally altered volcanic strata that locally contain abundant pyrite and alunite. However, the sulfate content of two other wells in Jackass Flats (74-57 and 73-58) - one of them no farther from the Calico Hills than well 74-61 is less than $0.5 \mathrm{meq} / \mathrm{l}$.

Although altered volcanic and carbonate rocks, or stocks, may locally influence the sulfate content of water within the carbonate aquifers, they are not considered an important regional source of sulfate because (1) their distribution is limited, and their size is relatively small; (2) the transmissibility of stocks and altered volcanic rocks is usually very low; and (3) pyrite and other sulfides presumably are oxidized chiefly in the vadose zone and perhaps also in the uppermost part of the zone of saturation but the aridity of most of the region precludes movement of much (if any) water through the vadose zone. These factors tend to prevent the contact of a significant volume of ground water with these sources of the sulfate.

A second potential source of sulfate in the ground water within the lower carbonate aquifer is evaporite deposits, specifically gypsum laminae or strata within the Paleozoic rocks east of Nevada Test Site. Sedimentary gypsum occurs in the Permian and Triassic rocks in the southeastern one-third of the Spring Mountains and in several mountain ranges east of the study area, but no gypsum or other evaporites have been reported in the Paleozoic rocks older than Permian in the study area. Furthermore, the geologic maps of Clark and Lincoln Counties indicate that no Permian or Triassic rocks occur in the ridges flanking Indian Springs, Three Lakes, or Desert Valleys. Permian rocks are probably absent also in the subsurface, because most of the exposed rocks are Devonian or older, which indicates generally deep erosion of the Paleozoic sequence in the area east of Nevada Test Site. Permian carbonate rocks composing the upper carbonate aquifer are present in western Yucca Flat, but these strata include no evaporites. Actually, the chemical quality of water in the area east of Nevada Test Site indicates that neither gypsum nor other sulfate-bearing evaporites occur in significant amount within the Paleozoic strata there. The chemical influence of any evaporites along the margins of the Ash Meadows ground-water basin is presumably already reflected by the water quality of areas IA, IB, and ID (table 8); the sulfate in these waters is negligible in comparision with quantities in ground water from terrane containing sedimentary gypsum.

The most likely source of the additional sulfate within the water of the lower carbonate aquifer beneath areas IIIA-IIIC is the solution of gypsum from the basal strata composing the tuff aquitard. In the southern half of Nevada Test Site, the oldest Tertiary rocks consist primarily of tuffaceous sedimentary rocks, claystone, and freshwater limestone of the Rocks of Pavits Spring and the Horse Spring Formation (table 1). Laminae of gypsum have been reported in the Rocks of Pavits Spring near Mercury, Nev. (E. N. Hinrichs, oral commun., 1966). Longwell, Pampeyan, Bowyer, and Roberts (1965, p. 45-48) reported gypsum in the Horse Spring Formation in eastern Cläk County, and Denny and Drewes (1965, p. L18) mentioned sparse gypsum in the Tertiary claystone south of Ash Meadows. Thus, in areas of downward crossflow beneath Nevada Test Site, solution of the gypsum in these basal Tertiary strata could add important quantities of sulfate to water in the lower carbonate aquifer.

Because the chemical quality of water in the lower carbonate aquifer beneath eastern Frenchman Flat (well 75-73) is almost identical with that of water discharging at Ash Meadows (pl. 3), sulfate-rich water may leak downward principally east or northeast of Frenchman Flat, in northern Indian Springs and Three Lakes Valleys. The Horse Spring Formation crops out in ridges bordering these valleys and probably also underlies these valleys in the zone of saturation. Gypsum within this formation probably constitutes a source of sulfate, if downward crossflow occurs.

Direct evidence for very high sulfate and sodium contents in ground water from the basal Tertiary rocks composing the tuff aquitard is. derived from well 68-69, and evidence of moderate increases in sulfate and sodium with depth is suggested by well $73-66$. Well $68-69$, in central Mercury Valley (fig. 1), bottomed at a reported depth of 1,220 feet in saturated Tertiary sedimentary rocks (fig. 33). The interval from 500 to 1,220 feet consists of siltstone, mudstone, and shale (B. D. Jorgensen, written commun., 1951); these strata tentatively correlate with the Rocks of Pavits Spring, although they might also be in the Horse Spring Formation (table 1). Jorgenson reported that the chief aquifer is a 5-foot-thick pinkish medium-grained sandstone at a depth of about 1,133 feet; the yield of this sandstone was reported as less than $5 \mathrm{gpm}$. A chemical analysis of water bailed from well 68-69 reported by Schoff and Moore (1964, p. 27) is presented in table 11 . The water is unlike other waters described in this report. Sodium constitutes about 75 percent of the total cations, and sulfate about 95 percent of the anions. A pie diagram for this water is not shown on plate 3 because, even if drawn to half scale, it would obscure large parts of the map. In a discussion with $\mathrm{Mr}$. S. R. McKinney of Las Vegas, Nev., the driller of well 68-69, the senior author learned that water from well 74-70a (in Frenchman Flat) and some aqua gel were used in drilling the well with cable tools, but no gypsum 
TABLE 11. - Chemical analysis of water from test well 68-69, Mercury Valley, Nye County

\begin{tabular}{|c|c|c|}
\hline & $\begin{array}{c}\text { Milligrams } \\
\text { per liter }^{1}\end{array}$ & $\begin{array}{l}\text { Milliequivalents } \\
\text { per liter }\end{array}$ \\
\hline $\begin{array}{l}\mathrm{Silica}\left(\mathrm{SiO}_{2}\right) \\
\text { Calcium( } \\
\text { Magnesium }(\mathrm{Mg}) \\
\text { Sodium }(\mathrm{Na}) \\
\text { Bicarbonate }\left(\mathrm{HCO}_{3}\right) \\
\text { Carbonate }\left(\mathrm{CO}_{3}\right) \\
\text { Sulfate }\left(\mathrm{SO}_{4}\right) \\
\text { Chloride }(\mathrm{Cl}) \text { ) } \\
\text { Dissolved solids }(\mathrm{sum}) \\
\text { Hardness as } \mathrm{CaCO} \text { (total) } \\
\text { pH }\end{array}$ & $\begin{array}{r}23 \\
281 \\
90 \\
1,290 \\
98 \\
\text { Tr } \\
3,600 \\
235 \\
5,420 \\
1,070 \\
8.1\end{array}$ & $\begin{array}{r}14.02 \\
7.40 \\
56.12 \\
1.61 \\
\overline{74.99} \\
.99 \\
--- \\
--- \\
--\end{array}$ \\
\hline
\end{tabular}

${ }^{1}$ Analysis by Smith-Emery Co. of Los Angeles, Calif., 1951. Sodium, sulfate, dissolved solids, and hardness have been rounded to Survey standards.

${ }^{2}$ Erroneously reported as 98 by Schoff and Moore $(1964$, p. 27$)$

cement was used. The chemical analysis should be representative of water from the Rocks of Pavits Springs or, perhaps, from the Horse Spring Formation.

According to Schoff and Moore (1964, p. 28):

the unusual character of the water from well 68-69 suggests that the confining layer under the zone of saturation provides a relatively tight seal. The mineralized water seems not to appear in wells tapping other aquifers. The well is less than 3 miles "upstream" from well $67-68$, which taps carbonate rocks and has water containing only $330 \mathrm{mg} / \mathrm{l}$ dissolved solids and $38 \mathrm{mg} / \mathrm{l}$ sodium ( 28 percent of total cations). No more than a trickle of the mineralized water can be reaching the carbonate rock aquifer at well $67-68$.

This observation has merit because nowhere in the lower carbonate aquifer is the sodium content more than 100 $\mathrm{mg} / \mathrm{l}$ or the sulfate content more than $200 \mathrm{mg} / \mathrm{l}$. The slow rate of leakage from the Cenozoic aquifers, which Schoff and Moore (1964) inferred, is supported by the hydraulic tests of the tuff aquitard in general and of the Rocks of Pavits Spring in particular.

Chemical analyses of perched (or semiperched) ground water tapped by well 73-66, in Rock Valley, southeast of Skull Mountain (fig. 1), indicate an increase in quantities of sulfate and sodium with depth in water within the tuff aquitard (Wahmonie Formation, Salyer Formation, Tuff of Crater Flat, and Rocks of Pavits Spring). Laboratory analyses of water swabbed from the hole during drill-stem tests of the tuff aquitard (depth intervals 77-693 and 1,565-1,695 ft) and pumped from the lower carbonate aquifer (depth in interval $3,140-3,400 \mathrm{ft}$ ) are given in table 12 . The first two analyses suggest a marked increase in sulfate and sodium to a depth of about 1,700 feet in the tuff aquitard. The content of these ions in the carbonate aquifer (third analysis) is presented for comparison.

The anomalously high sulfate content of water from well 68-69 and the threefold increase in sulfate with depth in the tuff aquitard in well 73-66 is believed due to solution of gypsum within the basal strata of the tuff aquitard. An explanation for the much higher sodium content in water from wells 68-69 and 73-66 than that in water from Tertiary and Quaternary strata in areas IIB
TABLE 12. - Chemical analyses of water from three depth intervals in test well 73-66, Rock Valley, Nye County

\begin{tabular}{|c|c|c|c|}
\hline \multicolumn{4}{|c|}{ [Analyses by U.S. Geol. Survey, Denver, Colo] } \\
\hline Depth interval (ft) $\ldots \ldots-\ldots$ & $77-693$ & $1,565-1,695$ & $3,140-3,400$ \\
\hline \multicolumn{4}{|c|}{ Major constituents, in milligrams per liter } \\
\hline $\begin{array}{l}\text { Silica }\left(\mathrm{SiO}_{2}\right) \\
\text { Calcium }(\mathrm{Ca}) \\
\text { Magnesium }(\mathrm{Mg}) \\
\text { Sodium }(\mathrm{Na}) \\
\text { Potassium }(\mathrm{K}) \mathrm{H} \\
\text { Bicarbonate }\left(\mathrm{HCO}_{3}\right) \\
\left.\text { Carbonate }(\mathrm{CO})_{3}\right) \\
\left.\text { Sulfate }\left(\mathrm{SO}_{4}\right)_{3}\right) \\
\text { Chloride }(\mathrm{Cl})\end{array}$ & $\begin{array}{c}32 \\
13 \\
1.0 \\
99 \\
6.4 \\
199 \\
0 \\
34 \\
32 \\
\end{array}$ & $\begin{array}{r}14 \\
4.0 \\
424 \\
4.0 \\
719 \\
68 \\
110 \\
35 \\
\end{array}$ & $\begin{array}{c}31 \\
68 \\
30 \\
63 \\
9.6 \\
273 \\
0 \\
181 \\
11 \\
\end{array}$ \\
\hline \multicolumn{4}{|c|}{ Physical characteristics and computed values } \\
\hline $\begin{array}{l}\text { Dissolved solids, in milligrams per liter } \\
\text { calculated } \\
\text { Hardness as milligrams per liter } \overline{\mathrm{Ca}} \overline{\mathrm{C}} \overline{\mathrm{O}}_{3}:-\end{array}$ & 327 & 981 & 534 \\
\hline $\begin{array}{l}\text { Total } \\
\text { Noncarbonate }\end{array}$ & $\begin{array}{r}37 \\
0\end{array}$ & $\begin{array}{r}10 \\
0\end{array}$ & $\begin{array}{r}293 \\
65\end{array}$ \\
\hline $\begin{array}{l}\text { Specific conductance } \\
\left(\mu \text { mhos per } \mathrm{cm} \text { at } 25^{\circ} \mathrm{C}\right) \\
\text { pH }\end{array}$ & $\begin{array}{r}492 \\
7.3 \\
22.0\end{array}$ & $\begin{array}{r}1,640 \\
8.8 \\
33.5\end{array}$ & $\begin{array}{r}751 \\
7.3 \\
64.5\end{array}$ \\
\hline Temperature $\left({ }^{\circ} \mathrm{C}\right) \ldots$ & 22.0 & 33.5 & 64.5 \\
\hline
\end{tabular}

to IID, and for the increase in sodium with depth in well $73-66$, is difficult because of the absence of information on the zeolite, clay, and evaporite mineralogy of the aquitard at these well sites. The sodium content of these well waters is tentatively attributed to one or more of the following: (1) Ion exchange of calcium, derived from solution of gypsum, for sodium in clays within the aquitard; (2) possible presence of sodium-bearing evaporite minerals, such as trona or nahcolite, in the basal tuff aquitard; and (3) possible continued alteration, by downward-moving water, of the sodium-rich zeolite minerals (clinoptilolite, mordenite, and analcime) that compose the bulk of certain strata within the aquitard. The strong tendency of sodium to remain in solution (Hem, 1959, p. 84-85) would enhance any of these mechanisms. Regional relations among absolute quantities of $\mathrm{Na}+\mathrm{K}, \mathrm{SO}_{4}+\mathrm{Cl}$, and $\mathrm{HCO}_{3}+\mathrm{CO}_{3}$ in the lower carbonate aquifer are shown in figure 40 .

In summary, ground water of the calcium magnesium bicarbonate facies found in the lower carbonate aquifer along the periphery of the Ash Meadows ground-water basin (areas IA, IB, and ID) is converted to the water of the calcium magnesium sodium bicarbonate facies, found in the aquifer beneath the central and southwestern parts of the basin (areas IIIA-IIIC), by means of downward leakage of sodium- and sulfate-rich water from the tuff aquitard. The higher sodium and sulfate contents of water in the carbonate aquifer beneath areas IIIA-IIIC than in water in the overlying Cenozoic aquifers and aquitards of areas IIB-IID, the proposed source of the sodium and sulfate, reflects sampling position. Wells in areas IIB-IID mostly tap water from the upper part of the zone of saturation within the Cenozoic hydrogeologic units and therefore do not reflect increases in sodium and sulfate believed to occur within the tuff aquitard with depth. 


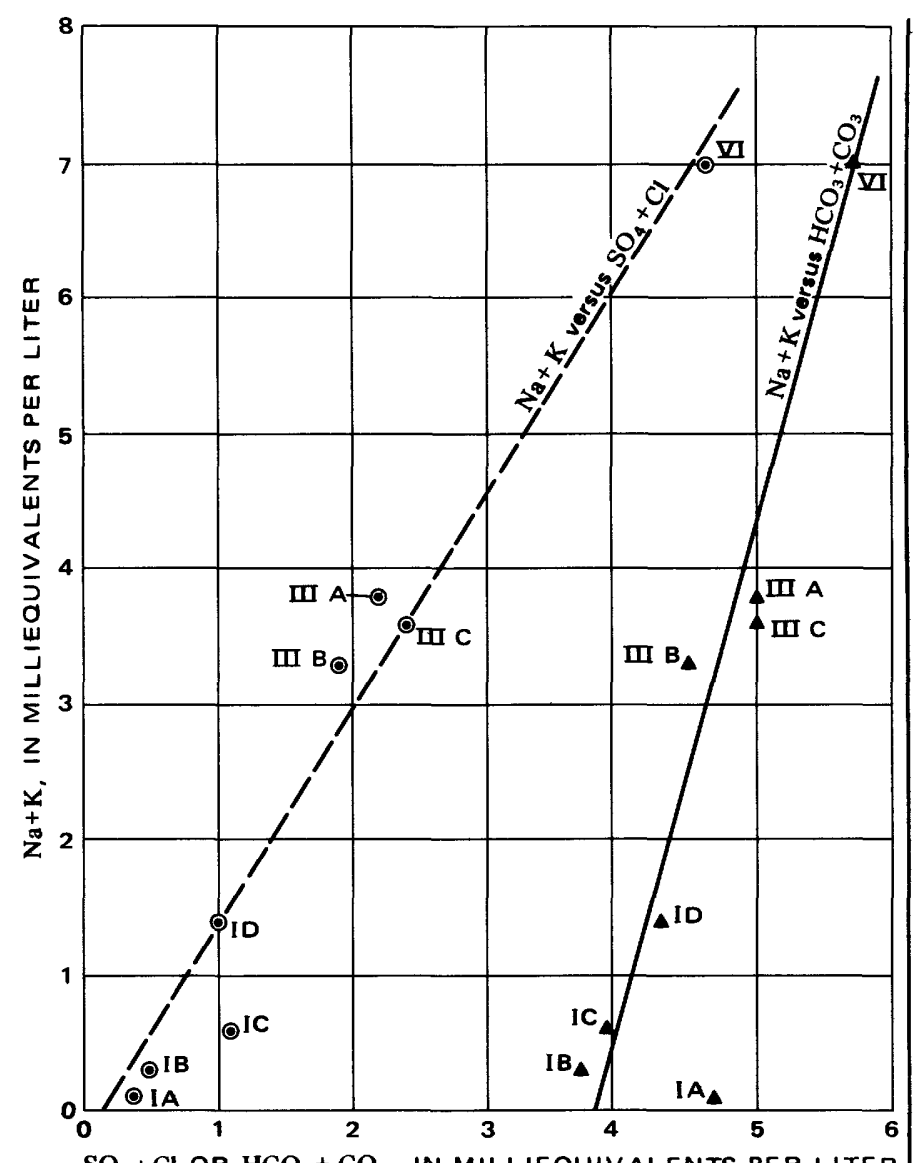

$\mathrm{SO}_{4}+\mathrm{Cl}$ OR $\mathrm{HCO}_{3}+\mathrm{CO}_{3}$, IN MILLIEQUIVALENTS PER LITER

FIGURE 40. - Regional variations in $\mathrm{Na}+\mathrm{K}, \mathrm{HCO}_{3}+\mathrm{CO}_{3}$, and $\mathrm{SO}_{4}+\mathrm{Cl}$ within the lower carbonate aquifer. Roman numerals refer to map numbers and areas listed in table 8; median values are from the same table.

\section{HYDROCHEMICAL EVIDENCE FOR REGIONAL GROUND-WATER FLOW}

Hydrochemical facies provide some quasiindependent evidence on the direction of ground-water movement in the lower carbonate aquifer, the magnitude of the intrabasin movement of ground water, and the boundaries of the Ash Meadows basin.

\section{HYDRAULIC CONNECTION BETWEEN PAHRUMP VALLEY AND ASH MEADOWS}

On the basis of water chemistry and head relation, Hunt, Robinson, Bowles and Washburn (1966, p. B28) suggested that the spring-water discharge at Ash Meadows comes from Pahrump Valley. They stated: "Water in Pahrump Valley is a bicarbonate water very similar to that at Ash Meadows *** ." They were correct in noting that water in both areas is rich in calcium, magnesium, and bicarbonate, but they did not note the significantly larger amounts of sodium, potassium, sulfate, chloride, and dissolved solids in the water of Ash
Meadows. This is shown by position of populations IC (Pahrump Valley) and IIIA (Ash Meadows springs) in figure 38 and by the data in table 8 . First, sodium and potassium, which constitute only about 10 percent of the cations in ground water from Pahrump Valley, constitute about 50 percent of the cations in the spring discharge at Ash Meadows. Second, sulfate and chloride, which constitute about 20 percent of the anions in Pahrump Valley, constitute about 30 percent at Ash Meadows. And last, the median dissolved-solids content of the Pahrump water is $290 \mathrm{mg} / \mathrm{l}$, in contrast to $420 \mathrm{mg} / \mathrm{l}$ at Ash Meadows. If Hunt, Robinson, Bowles, and Washburn (1966) could have seen all the analyses used by the authors of this report, particularly analyses of water from the lower carbonate aquifer, their conclusion on similarity of the waters would probably have been different.

The differences between the waters do not in themselves rule out the possibility of northwestward movement of ground water from western Pahrump Valley (or from Stewart Valley) into Ash Meadows. Could the chemical quality of the ground water change during movement between the two areas through either the valley-fill or the lower carbonate aquifer? This possibility appears slim for two reasons. First, analyses of water from the valley-fill aquifer in Pahrump Valley and data presented by Malmberg (1967, pl. 5) fail to reveal a progressive westward increase in sodium and potassium, sulfate and chloride, or dissolved-solids content of water in this aquifer. Only water from the very shallow wells (less than $100 \mathrm{ft}$ and usually less than $40 \mathrm{ft}$ deep) on and along the periphery of the playa in Stewart Valley has a similar or greater content of the ions indicated and of dissolved solids; however, this water is of the playa facies and, in any event, does not resemble that discharging from the major springs at Ash Meadows (pl. 3; table 8). Thus, water in the valley-fill aquifer is not a likely source of the water discharging at Ash Meadows. Second, the water in the lower carbonate aquifer beneath Pahrump Valley, although not sampled in wells, is also unlikely to contain the necessary quantities of sodium and potassium for reasons outlined below. The only sodium-rich ground water within the study area, except the playa facies, is in or has passed through rhyolitic volcanic aquifers or aquitards. If such strata underlie the valley fill beneath Pahrump Valley and if ground-water movement were downward from the Cenozoic rocks into the Paleozoic carbonate strata (as in Yucca or Frenchman Flats, for example), then the water in the carbonate aquifers beneath Pahrump Valley might contain quantities of sodium and potassium equivalent to those in the water at Ash Meadows. However, the direction of crossflow in northwestern Pahrump Valley is upward from older to younger rocks, 
as indicated by flowing wells, springs, and areas of phreatophyte discharge. Therefore, the sodium and the potassium contents of water in the lower carbonate aquifer beneath Pahrump Valley are probably similar to those of water in the carbonate aquifer in the Spring Mountains (area IA) and in Indian Springs Valley (area IB). (See table 8 and pl. 3.)

The remarkable chemical similarity of the discharge at all the major springs at Ash Meadows (pl. 3,; table 8) also suggests that little of the water discharging at Ash Meadows comes from Pahrump Valley or from Stewart Valley. If significant inflow were derived from these valleys, the spring discharge at the southeast end of the spring line (for example, at Big Spring or at Jack Rabbit Spring, fig. 34) would probably more closely resemble the ground water in Pahrump or Stewart Valleys than springs at the north end of the spring line 9 miles distant; such a resemblance does not exist. Some interbasin movement between Pahrump and Stewart Valleys and Ash Meadows must occur because of the head difference between the two areas, but the quantity of such movement probably does not exceed a few percent of the Ash Meadows discharge at most. (See calculation of underflow in the section "Relation to Pahrump Valley Ground-Water Basin.")

\section{DIRECTION OF GROUND-WATER MOVEMENT WITHIN THE LOWER CARBONATE AQUIFER BENEATH NEVADA TEST SITE}

Schoff and Moore (1964) suggested that ground water within the carbonate aquifers at Nevada Test Site (pl. 3, area IIIC) must be moving southwestward toward Ash Meadows. They noted that water from the carbonate and valley-fill aquifers in southern Indian Springs Valley (area IB) contained little sodium (with minor potassium) and less dissolved solids than water from the lower carbonate aquifer at Nevada Test Site; they therefore ruled out the possibility of southeastward movement from the test site to southern Indian Springs Valley. They did not consider eastward movement into northern Indian Springs Valley. Inherent in their use of sodium as a chemical tracer is the fact that sodium, once in solution, tends to stay in solution (Hem, 1959, p. 84-85).

Additional evidence in support of Schoff and Moore's conclusions is provided by figure 38 and table 8 . The water of area IIIC closely resembles that discharging at, and in the unnamed valley northeast of, Ash Meadows (areas IIIA and IIIB), but it differs significantly from water in Indian Springs, Three Lakes, and northwest Las Vegas Valleys (area IB) and Pahranagat Valley (area ID). Not only does the water in the lower carbonate aquifer of Nevada Test Site contain markedly more sodium and potassium than does the water in Indian
Springs, Three Lakes, northwest Las Vegas Valleys and Pahranagat Valley, but also it contains more sulfate and chloride. In contrast, the very close similarity of water in carbonate aquifers beneath the Nevada Test Site to that in Ash Meadows suggests that water of the Nevada Test Site is probably moving southwestward. However, southeastward or eastward movement of water into Indian Springs Valley probably cannot be ruled out on the basis of chemical evidence alone, because of the possible dilution of water derived from the Nevada Test Site by a significantly larger volume of water derived from the Spring Mountains.

ESTIMATES OF DOWNWARD CROSSFLOW FROM THE TUFF AQUITARD INTO THE LOWER CARBONATE AQUIFER

The variations in chemical quality of the ground water within the lower carbonate aquifer beneath and east of Nevada Test Site (area IB, ID, and IIIC, pl. 3) and the chemical difference between these waters and those in the tuff aquitard suggest that the chemical data can be used to compute the approximate magnitude of downward crossflow of semiperched water from the aquitard (underlying the valleys in and east of Nevada Test Site) into the lower carbonate aquifer.

In the discussion that follows, milliequivalents-perliter values of the ionic pairs sodium plus potassium and sulfate plus chloride for areas IA-IIIC (table 8) are taken as representative of sodium and sulfate, respectively. Justification for this shortcut was given in the section "Sources of Sodium and Sulfate Ions in Water of the Lower Carbonate Aquifer." The sodium or sulfate content of water from two cited wells, on the other hand, pertains to a single cation or anion.

Computation of crossflow is based on the following equations (Hem, 1959, p. 231):

$$
Q_{1} C_{1}+Q_{2} C_{2}=Q_{3} C_{3} \text {, and } Q_{1}+Q_{2}=Q_{3},
$$

where $Q_{1}$ is the discharge rate of the more saline water, $Q_{2}$ is the discharge rate of the less saline water, $Q_{3}$ is the discharge rate of the mixture (that is, $Q_{3}=Q_{1}+Q_{2}$ ), and the constants $C_{1}, C_{2}$, and $C_{3}$ represent the concentrations of the tracer constituent (sodium, for example) in the three discharges. Use of this formula at Nevada Test Site rests upon the following assumptions: (1) Sodium and sulfate in water of the lower carbonate aquifer are derived principally by flow from the overlying Tertiary rocks; (2) the cited chemical quality of the ground water from wells 68-69 and 73-66 (tables 11 and 12) is representative of water in the basal part of the tuff aquitard beneath the valleys east and northeast of the Nevada Test Site; (3) sodium and sulfate remain in solution once introduced into the lower carbonate aquifer; and (4) mixing of water from the tuff aquitard with water in the lower carbonate aquifer is complete at Ash Meadows. 
In applying the computation to the study area, equations above are combined as follows:

$$
Q_{1}=\frac{Q_{3}\left(C_{3}-C_{2}\right)}{\left(C_{1}-C_{2}\right)}
$$

$Q_{1}$ is the downward leakage of semiperched water from the tuff aquitard (the unknown), and $Q_{3}$ is the measured spring discharge at Ash Meadows, roughly 10,000 gpm. Similarly, $C_{3}$ represents the tracer concentration in the spring water at Ash Meadows (see table 8); $C_{2}$ is the same parameter for water within the carbonate aquifer along the periphery of the Ash Meadows basin (an average of the median values listed in table 8 for areas IB and ID); and $C_{1}$ applies to ground water in the basal part of the tuff aquitard (as represented by water from wells 68-69 and 73-66) (tables 11 and 12).

Using sodium as the tracer, with values of 56 (well 68-69), 0.8, and $3.8 \mathrm{meq} / \mathrm{l}$, respectively, for $C_{1}, C_{2}$, and $C_{3}$, the computed downward leakage $\left(Q_{1}\right)$ is about 550 gpm. The maximum sodium content of the water in well $73-66$ is about one-third that in well $68-69$ (18 versus 56 $\mathrm{meq} / \mathrm{l})$; the lower concentration indicates leakage of about 1,700 gpm. Because the water from well 73-66 is perched and was collected about 1,500 feet above the lower carbonate aquifer, it may not be as representative of water in the basal strata of the tuff aquitard as that collected from well 68-69.

Using sulfate as the tracer, with values of 75 (well 68-69), 0.75 , and $2.2 \mathrm{meq} / 1$ respectively for $C_{1}, C_{2}$, and $\mathrm{C}_{3}$, the computed downward leakage is $200 \mathrm{gpm}$. Water from the tuff aquitard tapped by well 73-66 cannot be used to determine leakage because the sulfate content of this water is about the same as that in the lower carbonate aquifer at Ash Meadows.

Finally, using dissolved-solids content as a measure of leakage and 5,420 (well 68-69), 245, and $420 \mathrm{mg} / \mathrm{l}$ for $C_{1}$, $C_{2}$, and $C_{3}$, respectively, $Q_{1}$ was found to be about 350 gpm. If the maximum dissolved-solids content of tuff water from well 73-66 (about $1,000 \mathrm{mg} / \mathrm{l}$ ) is used instead for $C_{1}$, then $Q_{1}$ amounts to about $2,300 \mathrm{gpm}$.

The preceding computations suggest that downward leakage from the tuff aquitard within the intermontane basins of the Ash Meadows ground-water basin into the lower carbonate aquifer is only a few percent to perhaps as much as 20 percent of the discharge at Ash Meadows.

Estimates of downward leakage computed using only the analysis of water from well 68-69 are of the same magnitude as estimates obtained from hydraulic data. The aggregate leakage of semiperched water beneath the six valleys is estimated roughly as 150 to 400 acre-feet per year, on the basis of hydraulic data. (See section "Sources of Recharge to the Lower Carbonate Aquifer.") Leakage computed using the chemical analyses and the salt-dilution formula ranges from 200 to $550 \mathrm{gpm}$ (about
300-900 acre-ft per yr). Thus, both methods, though crude and subject to one or more assumptions, indicate that the semiperched water may contribute only a few percent (1-5) of the ground water in the lower carbonate aquifer.

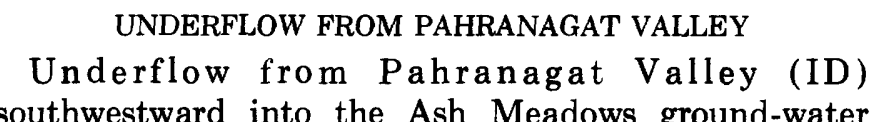
southwestward into the Ash Meadows ground-water basin through the lower carbonate aquifer is compatible with available chemical data. The spring water in Pahranagat Valley has about one-third as much sodium and potassium as that at Nevada Test Site and Ash Meadows. Similarly, the Pahranagat water has about one-half as much sulfate and chloride as that at Nevada Test Site and Ash Meadows. If movement is southwestward from Pahranagat Valley toward Nevada Test Site, downward crossflow from the tuff aquitard into the carbonate aquifer beneath Desert, northern Three Lakes, and northern Indian Springs Valleys could readily transform the chemical quality of Pahranagat water into that of water in the lower carbonate aquifer beneath eastern Frenchman Flat.

A comparison of the deuterium content of ground water in Pahranagat Valley, along the flanks of the Spring Mountains, and at Ash Meadows indicates that about 35 percent of the Ash Meadows discharge could originate from Pahranagat Valley (and possibly Garden and Coal Valleys). This conclusion is from the work of $I$. J. Winograd and Irving Friedman $(1969,1972)$. A summary of their work follows:

Winograd and Friedman sampled major low-level springs in Pahranagat Valley, at Ash Meadows, and along the flanks of the Spring Mountains and the Sheep Range. The springs sampled discharged either directly from the lower carbonate aquifer or from valley fill believed to be fed by the carbonate aquifer. Their data are given in table 13.

TABLE 13. - Summary of deuterium content of water from major springs, southern Great Basin, Nevada-California

[Analyses by U.S. Geol. Survey, Denver, Colo]

\begin{tabular}{|c|c|c|c|c|c|c|}
\hline \multirow{2}{*}{ Area } & \multirow{2}{*}{$\begin{array}{l}\text { Number of } \\
\text { sources } \\
\text { sampled }\end{array}$} & \multirow{2}{*}{$\begin{array}{c}\text { Number } \\
\text { of } \\
\text { samples }\end{array}$} & \multicolumn{4}{|c|}{$\delta \mathrm{D}$ (permil deviation from S.M.O.W.) } \\
\hline & & & Range & Mean & Median & $\begin{array}{l}\text { Standard } \\
\text { deviation }\end{array}$ \\
\hline $\begin{array}{l}\text { Pahranagat } \\
\text { Valley } \\
\text { Spring Mountains- }\end{array}$ & 3 & 9 & -110 to -115 & -113 & -113 & 1 \\
\hline $\begin{array}{l}\text { Sheep Range - } \\
\text { Ash Meadows - - }\end{array}$ & $\begin{array}{l}6 \\
4\end{array}$ & $\begin{array}{l}12 \\
15\end{array}$ & $\begin{array}{l}-97 \text { to }-106 \\
-99 \text { to }-110\end{array}$ & $\begin{array}{l}-102 \\
-106\end{array}$ & $\begin{array}{l}-102 \\
-107\end{array}$ & $\begin{array}{l}3 \\
3\end{array}$ \\
\hline
\end{tabular}

The deuterium content of these waters is reported as permil deviations $\left(\delta_{D}\right)$ from S.M.O.W. (Standard Mean Ocean Water). Winograd and Friedman showed that the differences between the means of the three areas is statistically significant at the conservative 0.01 level. Comparing the means, they argued that about 35 per- 
cent of the Ash Meadows discharge comes from the lower carbonate aquifer beneath Pahranagat Valley rather than from recharge to the Spring Mountains or Sheep Range. However, they pointed out that other interpretations of the deuterium data are possible.

At this writing, it appears safe only to say that the deuterium data are consistent with the hypothesis (formulated on the basis of geologic, hydrologic, and hydrochemical data) that water enters the Ash Meadows ground-water basin from the northeast.

\section{GROUND-WATER MOVEMENT IN AMARGOSA DESERT}

Examination of data for Amargosa Desert on plate 3 provides some evidence on ground-water movement in that valley. This evidence pertains to directions of crossflow in the east-central Amargosa Desert, position and possible effectiveness of the hydraulic barrier responsible for the spring discharge, and sources of water within the central part of the Amargosa Desert.

UPWARD CROSSFLOW IN THE EAST-CENTRAL AMARGOSA DESERT

The chemical quality of water from wells $17 / 52-8 \mathrm{c} 1$ and 17/51-1a1 (fig. 34 and pl. 3) in the east-central Amargosa Desert, in the unnamed valley northeast of the Ash Meadows spring line, suggests direct upward crossflow from the lower carbonate aquifer into the valley fill. Well $17 / 52-8 \mathrm{c} 1$ is 400 feet deep and may tap the lower carbonate aquifer as well as the valley-fill aquifer; well $17 / 51-1 \mathrm{a} 1$ is 135 feet deep and penetrates only valley fill (Walker and Eakin, 1963, table 3). A gravity map of the area indicates that the Paleozoic rocks are probably more than 1,500 feet below land surface at well $17 / 51-1 \mathrm{a} 1$. The chemical character of the water from these wells (see area IIIB on pl. 3 and in table 8) closely resembles that of water discharging from the springs at Ash Meadows, but it differs from that of water in valley-fill aquifers in other valleys within the study area. However, the median concentrations of principal ions in the well waters are 10 to 20 percent lower than median values for the same ions in the major springs at Ash Meadows, and the median dissolved-solids content is about 10 percent lower. The difference in absolute ionic content suggests that the upward leakage from the lower carbonate aquifer may have been diluted by ground water of lower dissolved-solids content. Such ground water might well have originated from local recharge; local recharge from runoff is likely in this part of the Amargosa Desert because the depth to water table is very shallow - only 33 feet at well $17 / 52-8 \mathrm{c} 1$ and 60 feet at well 17/51-1a1.

High sodium, sulfate, and dissolved-solids contents and low calcium and magnesium contents of water from well 65-66 (pl. 3), relative to wells $17 / 51-1 \mathrm{a} 1$ and $17 / 52-8 \mathrm{c} 1$, are puzzling; they may result from upward leakage, which was forced to pass through a great thickness of tuff aquitard enroute to the valley-fill(?) aquifer.

\section{SOURCES OF WATER IN THE CENTRAL AMARGOSA DESERT.}

The chemical quality of ground water in the valley-fill aquifer varies greatly from place to place in the central Amargosa Desert (area IV, pl. 3) and thereby contrasts with the more uniform chemical quality of water in the aquifer in surrounding areas. Water belonging to three of the four hydrochemical facies of table 8 , as well as to the playa facies, is found in this area (pl. 3); only the calcium magnesium bicarbonate facies is absent. Some of the water in the area west of the Ash Meadows spring line is of the calcium magnesium sodium bicarbonate facies. Water in the area between well 74-57 in western Jackass Flats and well $16 / 48-23 \mathrm{~b} 1$, northwest of the T and $\mathrm{T}$ Ranch, is of the sodium and potassium bicarbonate facies. Pie diagrams of water from two wells in the west-central and the northwestern parts of the valley (wells $13 / 47-35 a$ and 16/48-17a1) resemble the pie diagrams of the sodium sulfate bicarbonate facies found in Death Valley (area VI). Finally, water from shallow wells in the Death Valley Junction area is of the playa facies; these wells are along the periphery of Alkali Flat, where the depth to water ranges from 0 to 5 feet. Water from one spring and one well does not fit this general geographic distribution. Water from Ash Tree Spring $(17 / 49-35 d 1)$, for example, is of the sodium and potassium bicarbonate facies, which differs from surrounding sources. Water from well $17 / 50-29 \mathrm{~d} 1$, west of the inferred hydraulic barrier (fig. 34), is of the playa facies.

The pattern just described indicates that ground water in the central Amargosa Desert is probably derived from at least three sources. Water of the calcium magnesium sodium bicarbonate facies most likely comes from flow across the hydraulic barrier responsible for the spring line at Ash Meadows. Water of the sodium potassium bicarbonate facies southwest of Lathrop Wells probably comes from western Jackass Flats, and water in the west-central and northwestern Amargosa Desert probably comes from Oasis Valley. Thus, the pie diagrams of plate 3 suggest that water enters the central Amargosa Desert from the east, north, and northwest.

Because of the diversity of source areas for the ground water and uncertainties about the aquifers tapped by the deeper wells in the central Amargosa Desert, no attempt was made to define this water statistically, as was done for the other populations in table 8 .

Several other hydrologic inferences regarding the central Amargosa Desert may be made from the available chemical analyses, however:

1. The dissolved-solids content of water from wells 
74-57, 73-58, 15/49-22a $1,16 / 49-9 \mathrm{c} 1,16 / 48-15 \mathrm{a} 1$, and $16 / 48-23 \mathrm{~b} 1$ is significantly less than that of water from other wells in the desert (pl. 3). In fact, the first four wells yield the most dilute water sampled in the study area, except for southeastern Pahute Mesa. The six wells cited are along Fortymile Wash or its distributaries. Timber Mountain and Pahute Mesa highlands are tributary to this prominent arroyo via Fortymile Canyon (fig. 1). The location of the cited wells along this drainage suggests that the low dissolved-solids content may reflect recharge primarily via infiltration along the arroyo bed rather than underflow from areas north of Jackass Flats. Such infiltration may not have been a significant source of recharge since the last pluvial.

2. The low mineralization of the water tapped by wells 15/49-22a1 and 16/49-9c1 (west and southwest of Lathrop Wells) contrasts sharply with the mineralization of the water from wells $15 / 50-18 \mathrm{c} 5$ and 16/50-7c1 (at and south of Lathrop Wells). This contrast, suggesting that little ground water is moving westward through the valley-fill deposits in the area, is supported by water-level and geologic data presented in the section "Possible Upward Leakage South of Lathrop Wells."

3. Chemical quality of water from well $17 / 50-29 \mathrm{~d} 1$ resembles that of the playa facies despite the well's proximity to the spring line, about 3 miles, and its relatively great depth, 530 feet. Water closely resembling the spring discharge would have been expected from a well of this depth and location. The well was flowing about 5 gpm when sampled in 1962 (Walker and Eakin, 1963, table 3); at time of sampling the bore was open to a depth of 471 feet. The driller's log of this hole indicates alternating clay and limestone strata to a depth of 245 feet, and sand, gravel, and clay between 245 and 530 feet. Evidence that the aquifer(s) tapped by well $17 / 50-29 \mathrm{~d} 1$ is poorly connected to the lower carbonate aquifer was provided by a short pumping test. Throughout a 4-hour pumping test the water temperature remained at $19.5^{\circ} \mathrm{C}(\mathrm{R} . \mathrm{H}$. Johnston, written commun., Mar. 1967), about $8.3^{\circ} \mathrm{C}$ lower than that in the lower carbonate aquifer, $3.5^{\circ} \mathrm{C}$ lower than that of the coolest major spring (Soda Spring; see fig. 35), and only $1.0^{\circ} \mathrm{C}$ above the mean annual temperature at Lathrop Wells. The test also showed that the gravel aquifer(s) was cut by at least one negative hydraulic boundary (R. H. Johnston, written commun., Mar. 1967). The low temperature, in particular, indicates that the water tapped by the well does not come directly from the lower carbonate aquifer. The anomalous chemical character of water from well 17/50-29d 1 may reflect slow movement of water through Cenozoic aquitards.

POSSIBLE SOURCE OF SPRING DISCHARGE AT FURNACE CREEK WASH-NEVARES SPRINGS AREA, DEATH VALLEY

Hunt, Robinson, Bowles, and Washburn (1966) concluded that the water discharging from the major springs in the Furnace Creek Wash-Nevares Springs area is derived from Pahrump Valley. They stated (p. B40):

However, the composition of the water discharging in Death Valley differs in detail from that in the valley fill above Eagle Mountain $* * *$ but it is much like the water at the Ash Meadows springs, which suggests that the water discharging in Death Valley has had the same history as that discharging at Ash Meadows. Probably the water discharging at the springs in Death Valley, like that at Ash Meadows, is derived directly from Pahrump Valley by movement along faults in the bedrock under the valley fill.

Plate $\overline{3}$, and table 8 indicate that the spring discharge in the Furnace Creek Wash-Nevares Springs area differs markedly in chemical quality from the water in Pahrump Valley and to a lesser, but significant, extent from spring discharge at Ash Meadows. Such differences alone do not preclude the movement postulated by Hunt, Robinson, Bowles, and Washburn (1966), because the chemical quality of the water may change enroute to Death Valley. However, the available chemical analyses suggest a more likely source for the Furnace Creek Wash-Nevares Springs water than ground water in Pahrump Valley. Figure 38 suggests that the Death Valley water may be a mixture (with addition of sulfate and chloride) of water from Oasis Valley (area IIG) and Ash Meadows (area IIIA). Plate 3 suggests that the water may be closely related to that in valley fill beneath the west side of the Amargosa Desert. (See pie diagrams for wells $13 / 47-35 a, 16 / 48-17 \mathrm{a} 1$, and $27 \mathrm{~N} / 4-27 \mathrm{~b} 2$.) Therefore, on the basis of chemical quality of water, the spring discharge at the Furnace Creek Wash-Nevares Springs area seems to come from water in the valley-fill aquifer of the central and northwestern Amargosa Desert rather than directly from Pahrump Valley or from Pahrump Valley via Ash Meadows. Whether water in the valley-fill aquifer can enter the lower carbonate aquifer, and thereby reach Death Valley, cannot, however, be evaluated until head relations between these aquifers are determined for the central and south-central Amargosa Desert.

SUMMARY OF HYDROCHEMICAL EVIDENCE ON REGIONAL MOVEMENT OF GROUND WATER

Major inferences pertinent to the ground-water regimen, made largely on the basis of hydrochemical variations, are as follows:

1. Ground water beneath Nevada Test Site moves towards the Ash Meadows area. 
2. Chemical quality of the water within the lower carbonate aquifer may not change markedly with depth. Potable water may be present to depths as great as 10,000 feet in the Ash Meadows groundwater basin.

3. Sulfate and sodium contents in ground water in the tuff aquitard beneath the Nevada Test Site increase with depth, at least locally.

4. Ground water within the tuff aquitard drains into the underlying lower carbonate aquifer beneath Nevada Test Site and possibly also beneath the valleys east and northeast of Nevada Test Site.

5. Leakage of water from the tuff aquitard into the lower carbonate aquifer is probably less than 5 percent of the water discharged at Ash Meadows.

6. Ground water may move into the Ash Meadows basin from Pahranagat Valley and if so, may constitute as much as 35 percent of the spring discharge at Ash Meadows.

7. Ground-water movement from Pahrump or Stewart Valleys into the Ash Meadows area is minor.

8. Ground water within the central Amargosa Desert comes from the east, the north, and the northwest.

9. Flow from the central Amargosa Desert into Death Valley is the most likely source of the major spring discharge in east-central Death Valley.

\section{GROUND-WATER VELOCITY}

A major objective of the study of the hydrogeology of Nevada Test Site and vicinity was a determination of the ground-water velocity in the principal aquifers and aquitards. Velocity was determined for ground water in the tuff aquitard in Yucca Flat and for water in the lower carbonate aquifer in central Yucca Flat and beneath the Specter Range. Velocity was not estimated for ground water in the welded-tuff and valley-fill aquifers because in Yucca and Frenchman Flats the movement of water through these rocks is controlled by the surrounding and underlying tuff aquitard.

Ground-water velocity in the tuff aquitard was determined using the equation

$$
V=\frac{P I}{7.48 p},
$$

where $V$ is velocity, in feet per day; $P$ is interstitial permeability, in gallons per day per square foot; $I$ is the hydraulic gradient, in feet per foot; and $p$ is interstitial effective porosity expressed as a decimal. (A correction for the effect of temperature on permeability may also be incorporated into the formula but is not necessary for estimating velocity at Nevada Test Site. The possible variations in $P, I$, and $p$ far exceed corrections for temperature.) Values for $P, p$, and $I$ were obtained from tables 5 and 6.

Ground-water velocity in the lower carbonate aquifer was determined using the equation

$$
Q=A p v,
$$

where $Q$ is underflow, in cubic feet per day; $A$ is the cross-sectional area of flow, in square feet; $p$ is effective fracture porosity, expressed as a decimal; and $v$ is velocity, in feet per day. Values for $Q, A$, and $p$ were obtained from data in this report or were estimated.

The velocity determinations are crude in that they vary by two to three orders of magnitude at each of the three places where velocity was computed. Nevertheless, the determinations are still valuable (for example, for first approximation of the movement of certain radionuclides) because of the major differences between the velocity in the tuff aquitard beneath Yucca Flat, in the lower carbonate aquifer beneath central Yucca Flat, and in the lower carbonate aquifer beneath the Specter Range.

VELOCITY OF MOVEMENT FROM THE TUFF AQUITARD INTO THE LOWER CARBONATE AQUIFER IN YUCCA FLAT

Ground water in the tuff aquitard beneath Yucca Flat is semiperched above the lower carbonate aquifer and is slowly draining into the deeper aquifer through the clayey tuff at the base of the aquitard or by movement toward a centrally located hydraulic sink. Movement of water in the aquitard by either method is probably controlled by interstitial permeability.

The estimated average velocities are given in table 14, which shows flow rates for two limiting conditions and for an intermediate condition. For first condition, where $P=0.00005$ gpd per sq $\mathrm{ft}$ and $p=10$ percent (or 0.10 for computations), the interstitial permeability of the clayey tuff exerts principal control on the rate of downward movement. This condition results in a minimum value of velocity. For the third condition, where $P=0.005 \mathrm{gpd}$ per sq $\mathrm{ft}$ and $p=30$ percent, the interstitial permeability of zeolitized tuff controls downward movement of water and results in maximum velocity values. These permeability and porosity values approximate the median values determined from laboratory analyses of cores of zeolitized and clayey tuff and clayey sediments. (See table 5.) The limiting values of the vertical hydraulic gradient for each condition are taken from table 6 . The average hydraulic gradient within the clayey tuff at the base of the aquitard may be greater than the 0.2 foot per foot, but even a threefold increase in gradient does not produce a significant increase in average velocity.

The significance of the computations in table 14 is that the average velocities of downward movement are 
TABLE 14. - Estimated ground-water velocity in tuff aquitard, Yucca Flat, Nye County

\begin{tabular}{|c|c|c|c|c|c|c|}
\hline \multirow{2}{*}{$\begin{array}{c}\text { Interstitial } \\
\text { permeability } \\
\text { (gpd per } \\
\text { sq ft) } \\
(P)\end{array}$} & \multirow{2}{*}{$\begin{array}{c}\text { Effective } \\
\text { interstitial } \\
\text { porosity } \\
\text { (percent) } \\
\text { (p) }\end{array}$} & \multirow{2}{*}{$\begin{array}{c}\text { Hydraulic } \\
\text { gradient } \\
\text { (ft } \\
\text { per ft) } \\
(I)\end{array}$} & \multicolumn{2}{|c|}{$\begin{array}{c}\text { Average vertical } \\
\text { velocity }\end{array}$} & \multirow{2}{*}{$\begin{array}{c}\text { Years for } \\
\text { water } \\
\text { to move } \\
1,000 \\
\mathrm{ft}\end{array}$} & \multirow{2}{*}{$\begin{array}{c}\text { Volume of } \\
\text { downward } \\
\text { leakage } \\
\text { (acre-ft } \\
\text { per yr) }\end{array}$} \\
\hline & & & $\begin{array}{c}\text { Feet } \\
\text { per day }\end{array}$ & $\begin{array}{c}\text { Feet } \\
\text { per year }\end{array}$ & & \\
\hline \multirow[t]{2}{*}{0.00005} & 10 & 0.02 & $1 \times 10^{-6}$ & $5 \times 10^{-4}$ & $2 \times 10^{6}$ & 2 \\
\hline & & .2 & $1 \times 10^{-5}$ & $5 \times 10^{-3}$ & $2 \times 10^{5}$ & 20 \\
\hline \multirow[t]{2}{*}{.0005} & 20 & .02 & $7 \times 10^{-6}$ & $2 \times 10^{-3}$ & $4 \times 10^{5}$ & 20 \\
\hline & & .2 & $7 \times 10^{-5}$ & $2 \times 10^{-2}$ & $4 \times 10^{4}$ & 200 \\
\hline \multirow[t]{2}{*}{.005} & 30 & .02 & $4 \times 10^{-5}$ & $2 \times 10^{-2}$ & $6 \times 10^{4}$ & 200 \\
\hline & & .2 & $4 \times 10^{-4}$ & $2 \times 10^{-1}$ & $6 \times 10^{3}$ & 2,000 \\
\hline
\end{tabular}

Assumes vertical crossflow through area of $66 \mathrm{sq} \mathrm{mi} \mathrm{(about} 18 \times 10^{8} \mathrm{sq} \mathrm{ft}$ ).

extremely small regardless of input data. Estimated vertical velocities range from $5 \times 10^{-4}$ to 0.2 foot per year. Most of the data in the table represent permeability measured approximately parallel to bedding, which is generally greater than vertical permeability. If data on vertical permeability were available, flow rates in the table would probably be somewhat smaller than shown.

The average vertical velocities in table 14 are reduced significantly if the water in the tuff aquitard is assumed to move laterally toward a sink in the center of the valley from which it then moves vertically into the lower carbonate aquifer. (See section "Intrabasin Movement.") The average horizontal component of hydraulic gradient in the tuff aquitard ranges from $1 / 300$ to $1 / 3$ of the vertical gradient. (See table 6.) The average velocities given in the table would be reduced proportionately if movement were predominantly horizontal.

Velocities in table 14 may be used to obtain rough values of the age of ground water within the tuff aquitard. The saturated thickness of the tuff aquitard ranges from a few to as much as 1,500 feet. Assuming an average saturated thickness of 1,000 feet, the average time needed for a water particle to move from the top to the bottom of the tuff aquitard is about 6,000 to $2,000,000$ years; if lateral movement to a centrally located hydraulic sink is assumed, considerably older ages are indicated, at least for the water in the lower parts of the aquitard. Because the head differential between the tuff aquitard and the lower carbonate aquifer probably was greater during and immediately after the close of the last pluvial period (about 9,000 yr ago), ground water near the base of the tuff aquitard today probably moved through higher parts of the aquitard in less time than present hydraulic gradients suggest.

A carbon-14 date of water from the valley-fill aquifer in Frenchman Flat suggests that the age of the ground water in the tuff aquitard is probably in the range of several tens of thousands of years. This water, from well $74-70 \mathrm{a}$ (fig. 31 ), is about 13,000 years old (Grove and others, 1969). Accordingly, water in the tuff aquitard beneath this well site is probably at least several tens of thousands of years old; an age of several hundred thousand years is not beyond imagination for waters near the base of the aquitard in Yucca or Frenchman Flats.

\section{VELOCITY WITHIN THE LOWER CARBONATE AQUIFER BENEATH CENTRAL YUCCA FLAT}

Average ground-water velocity within the lower carbonate aquifer beneath central Yucca Flat was estimated through use of the formula $Q=A p v$. The formula requires an estimate of the flow through the aquifer $(Q$, in cubic feet per day), the cross-sectional area of flow $(A$, in square feet), and the effective fracture porosity ( $p$, as a decimal). Of the variables, the volume $(Q)$ and the cross-sectional area $(A)$ of flow are reasonably well known. However, the magnitude of the effective fracture porosity $(p)$ is difficult to estimate. It may be as large as 1 or 2 percent, a value suggested by examination of outcrops of the carbonate aquifer, or conceivably as low as 0.01 percent, suggested by the sparseness of waterbearing fractures penetrated in test holes. Thus, a variation of two orders of magnitude in effective fracture porosity is possible. In contrast, estimates of the volume of flow and the cross-sectional area of flow are probably in error by less than a factor of 2 or 3 .

The area of underflow $(A)$ used in the computation of velocity across central Yucca Flat was assumed to be 10 miles long and 5,000 feet thick. The fence diagram for Yucca Flat (pl. 2A). and cross sections by Harley Barnes (unpub. data) suggest that the underflow area may be as much as $1 \frac{1 / 2}{2}$ to 2 times as large as the assumed area but refinement of the area of underflow is not warranted because of the potentially large variation in effective porosity.

The quantity of water moving through the lower carbonate aquifer beneath central Yucca Flat probably is less than 350 acre-feet per year (see discussion in section "Quantity Derived From Northwest Side of Basin,") and is considered equivalent to the sum of (1) downward leakage from the tuff aquitard; (2) underflow into the aquifer from east and west through the lower and upper clastic aquitards; and (3) possible underflow into the aquifer from the west through the lower carbonate aquifer, which underlies the upper clastic aquitard.

Estimates of the velocity in the lower carbonate aquifer beneath central Yucca Flat for the cited values for $Q$ and $A$ are summarized in table 15 . The estimated velocity ranges from 0.02 to 2.0 feet per day, or from 6 to 600 feet per year. The variation of two orders of 
magnitude reflects the uncertainty of the magnitude of effective fracture porosity. The velocity estimates for each assumed porosity are maximum values, because the cross-sectional area used was a minimum area and because only half of the 350 acre-feet is likely to have originated north of the centrally located section of underflow.

The velocities cited in the table are average velocities, and locally the velocity may exceed the average by several times. Marked areal variations in fracture transmissibility of the aquifer are expected, as is indicated by the spread of three orders of magnitude in values of fracture transmissibility (table 3). Discussion of the possibility of above-average velocities on a regional scale is presented in a following section of the report.

\section{VELOCITY WITHIN THE LOWER CARBONATE AQUIFER BENEATH SPECTER RANGE}

An estimate of probable upper limits of ground-water velocity within the lower carbonate aquifer in the study area is obtained by computing the average flow rate through the Specter Range. Such flow rates are of value in evaluating those estimated for the lower carbonate aquifer in Yucca Flat.

The cross-sectional area of flow is assumed to be 5 miles long and 5,000 feet thick. Flow through the cross section is considered equivalent to the measured discharge at Ash Meadows, about 17,000 acre-feet per year. The average porosity is assumed to range from 0.01 to 1 percent; these values probably satisfactorily bracket the possible range in effective fracture porosity of this aquifer. Ground-water velocity ranges from 2 to 200 feet per day. (See table 15.) The spread of two orders of magnitude in values of average velocity is due to uncertainty of the average fracture porosity.

The average-velocity estimates for the Specter Range area are considered to be probable upper limits of velocities for the lower carbonate aquifer, because beneath the Specter Range virtually the entire discharge of the Ash Meadows basin passes through a minimum underflow area. The possible errors in $Q$ and $A$ are probably less than 100 percent. Elsewhere in the flow system, the ground-water velocity must be considerably smaller either because $Q$ is markedly smaller, as in Yucca Flat, or because $A$ is much larger, as it probably is beneath Frenchman Flat.

The estimated average velocities beneath the Specter Range are about 100 times larger than those for the lower carbonate aquifer beneath central Yucca Flat. This difference principally reflects the differences in values of $Q$. The velocity within the lower carbonate aquifer beneath Yucca Flat is about $10^{3}$ to $10^{4}$ times greater than the estimated velocity within the tuff aquitard (table 14).
TABLE 15. - Estimated ground-water velocity in lower carbonate aquifer beneath central Yucca Flat and Specter Range, Nye County

\begin{tabular}{ccccc}
\hline & Assumed & \multicolumn{2}{c}{ Average velocity } & \\
\cline { 3 - 4 } Area & $\begin{array}{c}\text { Aserage } \\
\text { aeffective } \\
\text { fracture } \\
\text { porosity } \\
\text { (percent) }\end{array}$ & Feet & $\begin{array}{c}\text { Feet } \\
\text { per day }\end{array}$ & $\begin{array}{c}\text { Years for water } \\
\text { to travel 1 mile }\end{array}$ \\
& 1.0 & 0.02 & 6 & \\
\hline Central & .5 & .03 & 10 & 900 \\
Yucca & .1 & .2 & 60 & 500 \\
Flat. & .05 & .3 & 100 & 50 \\
& .01 & 2.0 & 600 & 9 \\
Specter & 1.0 & 2 & 600 & 9 \\
Range. & .5 & 3 & 1,000 & 5 \\
& .1 & 20 & 6,000 & .9 \\
& .05 & 30 & 10,000 & .5 \\
& .01 & 200 & 60,000 & .09 \\
\hline
\end{tabular}

EVIDENCE BEARING ON POSSIBLE FLOW THROUGH INTEGRATED SOLUTION CHANNELS OR HIGHLY PERMEABLE FRACTURE ZONES OF REGIONAL EXTENT

Three prominent solution caverns in or near the study area - Devils Hole, Gypsum Cave, and Worthington Cave - and the widespread development of caverns beneath other carbonate-rock terrane raise the possibility that a regionally integrated cavern system may exist beneath the study area. Such a system could readily result in flow velocities an order of magnitude higher than the average velocities cited for the Specter Range. Similarly, if zones of above-average fracture transmissibility are well connected regionally, the average flow rates cited would not be of value for current and future radiologic-safety appraisals of Nevada Test Site. These two possibilities are examined below.

Outcrop observations and drill-hole data for the Nevada Test Site and vicinity, presented in the section "Lower Carbonate Aquifer," indicate that solution caverns probably are not important controls of the regional movement of ground water. Furthermore, if an undetected integrated system of solution channels exists, it must have formed after the cessation of the block faulting (since late(?) Pliocene or early Pleistocene), which would have dismembered channels formed earlier and probably brought some to view.

The following suggest that development of extensive solution networks in the study area since the late Pliocene or early Pleistocene is unlikely:

1. The climate of most of the study area may have been semiarid during part or all of the Pleistocene. Much of the present relief of the Sierra Nevada developed during Pleistocene time, but some may have developed before early Pliocene (Christiansen, 1966, p. 177). Therefore, the study area probably was in the rain shadow of the Sierra Nevada at least during a part of the Pleistocene. Development of soils rich in organic matter, the major source of carbon dioxide in ground water, was probably marginal during this time except on the Spring Mountains and Sheep Range. 
2. If major cavern development is restricted to the zone immediately beneath a water table, as suggested by recent work (Davies, 1960; White, 1960; G. W. Moore, 1966a,b; and Bedinger, 1966), then solution is significant only beneath those areas where the lower carbonate aquifer is under water-table conditions - namely, beneath the ridges. Solution would be unlikely where the aquifer is buried by tens to hundreds of feet of saturated Tertiary rocks. In the Allegheny Plateau, Davies (1960) noted that "numerous deep oil wells that have penetrated the otherwise cavernous Mississippian and Devonian limestones have not encountered any significant cavern openings where the cover over the limestone is more than 100 feet thick and the site of the well is away from major valleys." Solution in the zone of saturation may not even occur in southern Nevada, even beneath areas where the aquifer is unconfined, because the available carbon dioxide might be completely used in dissolving carbonate rocks in the vadose zone, hundreds to more than 1,500 feet thick.

3. Except near major discharge areas, solution caverns formed at or near the water table during any of the pluvials would now be several feet to possibly tens of feet above the water table.

4. Finally, even in humid areas most explored caverns are only a few thousand feet long. The passages in the largest of the caverns aggregate several miles in length, but most caverns are areally small features. Moreover, most of the major caverns occur along large valleys; the passages in the major caverns decrease in size, though they are more numerous, in the part of the cavern away from major valleys (Moore, 1960, 1966a).

In conclusion, some solution caverns are found within the carbonate aquifer, and, undoubtedly, others will be discovered by drilling, particularly near major discharge areas. However, the probability for regionally integrated solution channels through which ground water flows at high velocities over distances of miles appears low, except in the immediate vicinity of the major discharge area and possibly in the vicinity of major hydraulic barriers.

If regionally integrated zones of above-average fracture transmissibility exist, they also probably formed after the middle to late Tertiary block faulting. Outcrop, drill-hole, and potentiometric data and geologic mapping suggest that klippen (erosional remnants of overthrust sheets, or gravity slump blocks) and rocks in areas of intense structural deformation (that is, the Specter Range) have above-average fracture transmissibility. Most of the deformation of the Paleozoic carbonate rocks occurred during the Late Cretaceous and early Tertiary orogeny. The overthrust sheets and other structures in the Paleozoic rocks potentially favoring high transmissibility are now discontinuous due to (1) the deep erosion of the carbonate rocks postdating the orogeny and (2) the repeated offset of these rocks by middle to late(?) Tertiary block faulting. Thus, if zones of above-average fracture transmissibility are to be continuous over distances of miles, avenues of above-average transmissibility must exist along the Tertiary fault planes. Possible evidence against such hydraulic connection is suggested by the presence of one or more hydraulic barriers in two-thirds of the wells test pumped.

In summary, the authors are not claiming that all zones of above-average fracture transmissibility are isolated from each other, that individual or combined zones may not extend for thousands of feet, or that the rocks in some areas, such as the Specter Range, are not more transmissible than rocks in other areas, such as Yucca Flat. They believe that zones of above-average fracture transmissibility are probably separated by zones of average and below-average transmissibility and, therefore, that the continuity of zones of above-average transmissibility over distances of tens of miles is improbable.

\section{RECOMMENDATIONS FOR FURTHER STUDY}

Because of the geologic complexity of the region, the drilling of tens of additional deep test holes, although it would increase the qualitative knowledge of the system, might not result in a quantitative understanding of the hydrogeology of the area. However, the following three steps are suggested as a modest means of testing and adding to existing knowledge when and if a reevaluation of the hydrogeology of the area is required.

1. Study of the isotopic content of water from all wells and major springs in the study area, including the large springs in Pahranagat, Pahrump, and Death Valleys. The isotopes of importance are $C^{14}, C^{13}, H^{3}$, $D, O^{18}$, and, possibly, $S^{34}$. Water from the base of the tuff aquitard should also be sampled and dated wherever possible, in order to evaluate the influence of the downward leakage on the isotopic content of the water in the lower carbonate aquifer.

2. Drilling of three additional test holes through the entire thickness of the lower carbonate aquifer to determine changes in character, frequency, permeability, head, and water chemistry of the water-bearing fractures with depth. One hole should be drilled near the center of the major trough in the potentiometric surface (pl. 1) either immediately northeast or southwest of the Specter Range. A second hole should be drilled in northern Desert Valley in the vicinity of the southernmost dry hole shown on plate 1 . The third well should be 
drilled in the narrow valley between southern Sheep Range and southern Desert Range, at about the latitude of Sheep Peak. Downhole photography in the first hole might aid in an evaluation of the fracture porosity and therefore in the computation of average velocity beneath the Specter Range, whereas the head and hydrochemical data from the second and third holes might help to better define the eastern and northern boundaries of the Ash Meadows ground-water basin.

Hydraulic characteristics and water chemistry of the Cenozoic aquifers and aquitard should also be determined in the three proposed holes, if they are penetrated within the zone of saturation. Representative samples of water from the base of the tuff aquitard will be difficult to obtain because of the very low permeability of the rocks, but such samples are of major importance for estimating downward crossflow from the tuff aquitard into the carbonate aquifer.

3. Cuttings and water samples should be collected, and water level and depth of well should be recorded routinely for all new wells drilled along the periphery of Nevada Test Site. Collection of such data is relatively inexpensive, and some of it may help to better define the regional hydrogeology.

\section{SUMMARY}

The Nevada Test Site, a U.S. Atomic Energy Commission nuclear testing facility encompassing an area of about 1,400 square miles, has been the site of a detailed study of ground-water geology and hydrology. The test site lies within the miogeosynclinal belt of the Cordilleran geosyncline, where 37,000 feet of marine sediments accumulated during the Precambrian and Paleozoic Eras, and within a Tertiary volcanic province where as much as 13,000 feet of rocks were erupted from caldera centers. Except for a few small intrusive masses, Mesozoic rocks are absent. Quaternary and Tertiary detritus as much as 2,000 feet thick underlies the valleys.

The region has experienced two major periods of deformation. The first, in late Mesozoic and early Cenozoic time, resulted in both broad and tight folds and thrust faults in Precambrian and Paleozoic rocks. During middle to late Cenozoic time, block faulting produced the Basin and Range structure of the region. Displacements along major strike-slip faults measured several miles during both periods of deformation.

Precambrian to Middle Cambrian strata are predominantly quartzite and siltstone 10,000 feet thick. The Middle Cambrian to Upper Devonian strata are chiefly limestone and dolomite 15,000 feet thick. Upper Devonian and Mississippian rocks are chiefly argillite and quartzite about 8,000 feet thick. Pennsylvanian and
Permian rocks are chiefly limestone about 4,000 feet thick. No major unconformities or disconformities marked by deep subaerial erosion of underlying rocks occur within this miogeosynclinal section.

The Tertiary volcanic rocks are ash-flow tuff, ash-fall tuff, rhyolite, rhyodacite, and basalt; the tuffs are commonly of rhyolitic and quartz-latitic composition. Sedimentary rocks associated with the volcanic strata include conglomerate, tuffaceous sandstone and siltstone, calcareous lacustrine tuff, claystone, and freshwater limestone. The Tertiary rocks are largely of Miocene and Pliocene age, although Oligocene rocks are present. Extent, thickness, and physical properties of the Tertiary rocks vary widely within and between the intermontane valleys.

Precambrian and Paleozoic miogeosynclinal rocks, Tertiary volcanic and sedimentary rocks, and Quaternary and Tertiary valley fill are grouped into 10 hydrogeologic units. The grouping is based on similar hydraulic properties, lithologic character, and stratigraphic position. The hydrogeologic units, in order of decreasing age, are: Lower clastic aquitard, lower carbonate aquifer, upper clastic aquitard, upper carbonate aquifer, tuff aquitard, lava-flow aquitard, bedded-tuff aquifer, welded-tuff aquifer, lava-flow aquifer, and valley-fill aquifer. The lower clastic aquitard, the lower carbonate aquifer, and the tuff aquitard control the regional movement of ground water.

The coefficient of transmissibility of the lower clastic aquitard is less than 1,000 gpd per ft. The effective interstitial porosity of 20 cores ranges from 0.6 to 5 percent and has a median value of 1.9 percent. The coefficient of permeability of 18 cores ranges from 0.0000007 to 0.0001 gpd per sq $\mathrm{ft}$ and has a median value of 0.000002 . Although the clastic strata are highly fractured throughout the study area, regional movement of water through these rocks is probably controlled principally by interstitial permeability rather than fracture transmissibility because (1) the argillaceous strata have a tendency to deform plastically, (2) fractures in the brittle quartzite sequences tend to be sealed by interbedded micaceous partings or argillaceous laminae, and (3) the clastic rocks have low solubility.

The highly fractured to locally brecciated lower carbonate aquifer consists of limestone and dolomite. On the basis of pumping tests of 10 wells and regional flow analysis, the coefficient of transmissibility of the aquifer ranges from 600 to several million gallons per day per foot. Core examination indicates a fracture porosity of a fraction of 1 percent. The effective intercrystalline porosity of 25 cores ranges from 0.0 to 9.0 percent and has a median value of 1.1 percent. The coefficient of permeability of 13 cores ranges from 0.00002 to $0.1 \mathrm{gpd}$ per sq ft and has a median value of 0.00008 .

The water-bearing fractures are probably solution- 
modified joints, fault zones, and breccia. Drill-stem tests in eight holes suggest that the water-bearing fractures are few and widely spaced, are present to depths of at least 1,500 feet beneath the top of the aquifer and as much as 4,200 feet below land surface, do not increase or decrease with depth, and are no more abundant or permeable immediately beneath the Tertiary-preTertiary unconformity than elsewhere in the aquifer.

The lower carbonate aquifer contains several solution caverns in outcrop. One of the caverns, Devils Hole, reportedly extends at least 300 feet vertically into the zone of saturation. The caverns probably do not constitute a hydraulically integrated network of solution openings, except possibly near major discharge areas; variations in fracture transmissibility control the regional movement of ground water through the aquifer.

The upper clastic aquitard consists principally of argillite (about two-thirds of unit) and quartzite (about one-third of unit). Unlike the lower clastic aquitard and the lower carbonate aquifer, which are thousands of feet thick, of relatively uniform lithology, and widely distributed, the upper clastic aquitard is of hydrologic significance only beneath western Yucca Flat and northern Jackass Flats. In much of the area, it is represented by time-equivalent carbonate rocks, has been removed by erosion, or occurs well above the water table. The coefficient of transmissibility of this aquitard is probably less than $500 \mathrm{gpd}$ per $\mathrm{ft}$; interstitial permeability is negligible.

The tuff aquitard consists primarily of nonwelded ashflow tuff, ash-fall (or bedded) tuff, tuff breccia, tuffaceous sandstone and siltstone, claystone, and freshwater limestone. Despite the widely differing origins of these strata, they generally have one feature in common: their matrices consist principally of zeolite or clay minerals, which are responsible in part for the very low interstitial permeability of these relatively porous rocks. Strata composing the aquitard have moderate to high interstitial effective porosity (median values ranging from 10 to 39 percent), negligible coefficient of permeability (median values ranging from 0.00006 to 0.006 gpd per sq $\mathrm{ft}$ ), and very low coefficient of transmissibility (less than 200 gpd per ft). Evidence from several miles of tunnels indicates that the regional movement of ground water through the tuff aquitard is probably controlled by interstitial permeability rather than by fracture transmissibility.

The welded-tuff aquifer consists of moderately to densely welded ash-flow tuff. The coefficient of transmissibility of the aquifer at four well sites ranges from 200 to more than $100,000 \mathrm{gpd}$ per $\mathrm{ft}$ and is probably controlled principally by interconnected primary (cooling) and secondary joints; interstitial permeability is negligible.

The valley-fill aquifer consists of alluvial-fan, mudflow, fluvial deposits, and lake beds. The coefficient of transmissibility of the valley-fill aquifer at six well sites ranges from 800 to about 34,000 gpd per ft; average interstitial permeabilities range from 5 to $70 \mathrm{gpd}$ per sq ft.

Owing to the complex structural and erosional history of the area, the subsurface distribution and the saturated thickness of the hydrogeologic units differ from unit to unit and place to place. The structural relief on the pre-Tertiary hydrogeologic units commonly ranges from 2,000 to 6,000 feet within distances of a few miles and locally is as much as 500 feet within distances of 1,000 feet. Thus, the lower carbonate aquifer, which is generally buried and fully saturated at depths of hundreds to thousands of feet below most valley floors, is only partly saturated along flanking ridges. In contrast, in areas where the lower clastic aquitard occurs in structurally high positions, the lower carbonate aquifer either has been largely removed by erosion or occurs entirely, or largely, above the zone of saturation. Also, because of complex pre-early Tertiary deformation and deep erosion, only a fraction of the 15,000-foot aggregate thickness of the carbonate aquifer is usually present in the zone of saturation. In general, because of its great thickness, several thousand feet of the lower carbonate aquifer lies within the zone of saturation beneath most ridges and valleys of the study area.

Vertical displacement, ranging from hundreds to thousands of feet along block faults, affects the subsurface disposition and saturated thicknesses of the tuff aquitard and the welded-tuff and valley-fill aquifers. Beneath valleys that have deep $(700-1,900 \mathrm{ft})$ water tables, the depth to water also affects the saturated thickness of the tuff aquitard and the welded-tuff and valley-fill aquifers. In Yucca Flat, the valley-fill aquifer is saturated only beneath a 10 -square mile area where the aquifer thickness exceeds 1,600 feet. Similarly, the welded-tuff aquifer is only partly to fully saturated beneath the central part of that valley; it is unsaturated beneath margins of the valley, even though it is buried at depths of hundreds of feet.

Both intrabasin and interbasin movement of ground water occurs in the region. Intrabasin movement of ground water from welded-tuff and valley-fill aquifers to the lower carbonate aquifer occurs beneath several of the intermontane valleys of the study area. The volume of flow between the Cenozoic hydrogeologic units and the lower carbonate aquifer is usually small, because the aquifers are separated by the thick and widespread tuff aquitard. In Yucca and Frenchman Flats, water leaks downward at a rate less than 100 acre-feet per year in each valley. In east-central Amargosa Desert and on the upgradient side of major hydraulic barriers cutting the lower carbonate aquifer, intrabasin movement is upward from the lower carbonate aquifer into the younger 
hydrogeologic units. Interbasin movement characterizes flow through the lower carbonate aquifer underlying most of the valleys and ridges of south-central Nevada. Within the Nevada Test Site, water moves south and southwestward beneath Yucca and Frenchman Flats, Mercury Valley, and the east-central Amargosa Desert toward a major spring discharge area, Ash Meadows, in the Amargosa Desert. The hydraulic gradient ranges from 0.3 to 5.9 feet per mile. Interbasin movement through the carbonate rocks is significantly controlled by geologic structure. In the vicinity of major structures, the lower carbonate aquifer is compartmentalized either through its juxtaposition against the lower or upper clastic aquitard along major normal or thrust faults, by the occurrence of the lower clastic aquitard in structurally high position along major anticlines, or by gouge developed along major strike-slip faults. The water levels in the lower carbonate aquifer on opposite sides of such structures differ as much as 500 feet in a single valley and as much as 2,000 feet between valleys, although the hydraulic gradient within each aquifer compartment or block is only a few feet per mile.

Hydraulic, geologic, isohyetal, hydrochemical, and isotopic data suggest that the area hydraulically integrated by interbasin water movement in the lower carbonate aquifer is no smaller than 4,500 square miles and includes at least 10 intermontane valleys. This hydrologic system, the Ash Meadows ground-water basin, may, in turn, be hydraulically connected to several intermontane valleys northeast of the study area from which it may receive significant underflow. The principal discharge from the basin, about 17,000 acrefeet annually (about $10,600 \mathrm{gpm}$ ) occurs along a prominent fault-controlled spring line 10 miles long at Ash Meadows. The discharge of individual springs is as much as $2,800 \mathrm{gpm}$. Underflow beneath the spring line into the central Amargosa Desert is probable, but its magnitude cannot be estimated. Pahrump and Stewart Valleys, proposed as the major source of the spring discharge at Ash Meadows by earlier workers, contribute at most a few percent of the discharge. The major springs in eastcentral Death Valley (Furnace Creek Wash-Nevares Springs area) are probably fed by interbasin movement of water from central and south-central Amargosa Desert, but not from Pahrump Valley.

Five hydrochemical facies of ground water in and adjacent to the study area have been distinguished by percentages of major cations and anions. Ground water that has moved only through the lower carbonate aquifer or through valley fill rich in carbonate detritus is a calcium magnesium bicarbonate type. Water that has moved only through rhyolitic tuff or lava-flow terrane, or through valley-fill deposits rich in volcanic detritus, is a sodium potassium bicarbonate type. Water in the lower carbonate aquifer, in areas of downward crossflow from the Cenozoic aquifers and aquitards, is a mixture of these two types and is designated the calcium magnesium sodium bicarbonate type. It is characterized by about equal quantities of the cation pairs calcium plus magnesium and sodium plus potassium. Water in east-central Death Valley, probably a mixture of water of the third type and water from Oasis Valley, is a sodium sulfate bicarbonate type. Shallow ground water, such as that beneath saturated playas, is informally designated as the playa type. The chemistry of this water (dissolved-solids content as high as $50,000 \mathrm{mg} / \mathrm{l}$ ) varies widely and depends in part on the depth of the sampling point. Major inferences pertinent to the ground water regimen, made on the basis of hydrochemical data, are as follows:

1. Ground water beneath the Nevada Test Site moves towards the Ash Meadows area.

2. Chemistry of water in the lower carbonate aquifer may not change markedly to depths as great as 10,000 feet.

3. Leakage of water from the tuff aquitard into the lower carbonate aquifer is probably less than 5 percent of the spring discharge at Ash Meadows.

4. Underflow into the Ash Meadows basin, from Pahranagat Valley, may amount to as much as 35 percent of the spring discharge at Ash Meadows.

The estimated velocity of ground water moving vertically through the tuff aquitard into the lower carbonate aquifer in Yucca Flat ranges from 0.0005 to 0.2 foot per year; values toward the lower end of the range are more probable.

The estimated velocity of water in the lower carbonate aquifer beneath central Yucca Flat ranges from 0.02 to 2.0 feet per day. Velocity in the carbonate aquifer beneath the Specter Range ranges from 2 to 200 feet per day. The spread of two orders of magnitude in estimated velocities in the carbonate aquifer in each area is due principally to uncertainty about the fracture porosity of the aquifer.

\section{REFERENCES}

Albers, J. P., 1967, Belt of sigmoidal bending and right-lateral faulting in the western Great Basin: Geol. Soc. America Bull., v. 78, no. 2, p. 143-156.

Ammann, C. B., 1960, Case histories of analyses of characteristics of reservoir rock from drill-stem tests: Jour. Petroleum Technology, v. 12 , no. 5 , p. $27-36$.

Back, William, 1966, Hydrochemical facies and ground-water flow patterns in northern part of Atlantic Coastal Plain: U.S. Geol. Survey Prof. Paper 498-A, 42 p.

Baker, W. J., 1955, Flow in fissured formations: Fourth World Petroleum Cong. Proc., sec. II, p. 379-393.

Barnes, Harley, Christiansen, R. L., and Byers, F. M., 1965, Geologic map of the Jangle Ridge quadrangle, Nye and Lincoln Counties, Nevada: U.S. Geol. Survey Geol. Quad. Map GQ-363.

Barnes, Harley, Houser, F. N., and Poole, F. G., 1963, Geologic map of the Oak Spring quadrangle, Nye County, Nevada: U.S. Geol. Survey Geol. Quad. Map GQ-214. 
Barnes, Harley, and Poole, F. G., 1968, Regional thrust-fault system in Nevada Test Site and vicinity, in Eckel, E. B., ed., Nevada Test Site: Geol. Soc. America Mem. 110, p. 233-238.

Bedinger, M. S., 1966, Electric-analog study of cave formation, in Vineyard, J. D., ed., Limestone hydrology - a symposium with discussion: Natl. Speleol. Soc. Bull., v. 28, no. 3, p. 127-132.

Blankennagel, R. K., and Weir, J. E., Jr., 1973, Geohydrology of the eastern part of Pahute Mesa, Nevada Test Site, Nye County, Nevada: U.S. Geol. Survey Prof. Paper 712-B, 35 p.

Bradley, W. G., 1964, The vegetation of the Desert Game Range, with special reference to the desert bighorn: Desert Bighorn Council Trans. 1964, p. 43-67, fig. 2.

Burchfiel, B. C., 1964, Precambrian and Paleozoic stratigraphy of Specter Range quadrangle, Nye County, Nevada: Am. Assoc. Petroleum Geologists Bull., v. 48, no. 1, p. 40-56.

1965, Structural geology of the Specter Range quadrangle and its regional significance: Geol. Soc. America Bull., v. 76, no. 2, p. 175-191.

Byers, F. M., Jr., 1961, Porosity, density, and water content data on tuff of the Oak Spring Formation from the U12e tunnel system, Nevada Test Site, Nye County, Nevada: U.S. Geol. Survey TEI-811, open-file rept., $37 \mathrm{p}$.

Byers, F. M., Jr., and Barnes, Harley, 1967, Geologic map of the Paiute Ridge quadrangle, Nye and Lincoln Counties, Nevada: U.S. Geol. Survey Geol. Quad. Map GQ-577.

Carpenter, Everett, 1915, Ground water in southeastern Nevada: U.S. Geol. Survey Water-Supply Paper 365, 86 p.

Carr, W. J., 1964, Structure of part of the Timber Mountain dome and caldera, Nye County, Nevada, in Geological Survey research 1964: U.S. Geol. Survey Prof. Paper 501-B, p. B16-B19.

Christiansen, M. N., 1966, Late Cenozoic crustal movements in the Sierra Nevada of California: Geol. Soc. America Bull., v. 77, no. 2, p. $163-182$.

Christiansen, R. L., Lipman, P. W., Orkild, P. P., and Byers, F. M., Jr., 1965, Structure of the Timber Mountain caldera, southern Nevada, and its relation to basin-range structure, in Geological Survey research 1965: U.S. Geol. Survey Prof. Paper 525-B, p. B43-B48.

Clebsch, Alfred, Jr., 1959, Ground water, in Diment, W. H., and others, Geologic effects of the Rainier underground nuclear explosion, a summary progress report of the U.S. Geological Survey investigations: U.S. Geol. Survey TEI-355, open-file rept., p. 5-1 to $5-15$.

1960 , Ground water in the Oak Spring Formation and hydrologic effects of underground nuclear explosions at the Nevada Test Site: U.S. Geol. Survey TEI-759, 29 p. (Available from Office of Tech. Services, U.S. Dept. of Commerce, Washington, D.C.)

1961, Tritium age of ground water at the Nevada Test Site, Nye County, Nevada, in Short papers in the geologic and hydrologic sciences: U.S. Geol. Survey Prof. Paper 424-C, p. C122-C125.

Clebsch, Alfred, Jr., and Barker, F. B., 1960, Analyses of ground water from Rainier Mesa, Nevada Test Site, Nve County, Nevada: U.S. Geol. Survey TEI-763, open-file rept., $22 \mathrm{p}$.

Clebsch, Alfred, Jr., and Winograd, I. J., 1959, Ground water, in Wilmarth, V. R., and others, A summary interpretation of geologic, hydrologic, and geophysical data for Yucca Valley, Nevada Test Site, Nye County, Nevada: U.S. Geol. Survey TEI-358, open-file rept., p. 36-49.

Cornwall, H. R., and Kleinhampl, F. J., 1961, Geology of the Bare Mountain quadrangle, Nevada: U.S. Geol. Survey Geol. Quad. Map GQ-157.

1964, Geology of Bullfrog quadrangle and ore deposits related to Bullfrog Hills Caldera, Nye County, Nevada, and Inyo County, California: U.S. Geol. Survey Prof. Paper 454-J, 25 p.

Davies, W. E., 1960, Origin of caves in folded limestone, in Moore, G. W., ed., Origin of limestone caves - a symposium with discussion: Natl. Speleol. Soc. Bull., v. 22, pt. 1, p. 5-18.
Denny, C. S., and Drewes, Harald, 1965, Geology of the Ash Meadows quadrangle, Nevada-California: U.S. Geol. Survey Bull. 1181-L, $56 \mathrm{p}$.

Diment, W. H., Wilcox, R. E., Keller, G. V., Dobrovolny, Ernest, Kracek, F. C., Roller, J. C., Peselnick, Louis, Robertson, E. C., Lachenbruch, A. H., and Bunker, C. M., 1958, Properties of the Oak Spring Formation in Area 12 at the Nevada Test Site: U.S. Geol. Survey TEI-672, open-file rept., 120 p.

Diment, W. H., Wilmarth, V. R., Wilcox, R. E., Clebsch, Alfred, Jr., Manger, G. E., Hawley, C. C., Keller, G. W., Robertson, E. C., Peselnick, L. C., Bunker, C. M., Healey, D. L., Kane, M. F., Roth, E. F., Stewart, S. W., Roller, J. C., Jackson, W. H., Oliver, H. W., Byerly, P. E., and Mabey, D. R., 1959, Geologic effects of the Rainier underground nuclear explosion, a summary progress report of the U.S. Geological Survey Investigations: U.S. Geol. Survey TEI-355, open-file rept., $134 \mathrm{p}$.

Dolan, J. P., Einarsen, C. A., and Hill, G. A., 1957, Special applications of drill-stem test pressure data: Am. Inst. Mining Metall. Petroleum Engineers Trans., v. 210, p. 318-324.

Eakin, T. E., 1963, Ground-water appraisal of Pahranagat and Pahroc Valleys, Lincoln and Nye Counties, Nevada: Nevada Dept. Conserv. and Nat. Resources Ground-Water Resources - Reconn. Ser. Rept. 21, 36 p.

1965, Regional ground-water system in southeastern Nevada, in Abstracts for 1964: Geol. Soc. America Spec. Paper 82, p. 51.

1966, A regional interbasin ground-water system in the White River area, southeastern Nevada: Water Resources Research, v. 2, no. 2, p. 251-271.

Eakin, T. E., Schoff, S. L., and Cohen, Philip, 1963, Regional hydrology of a part of southern Nevada - A reconnaissance: U.S. Geol. Survey TEI-833, open-file rept., $40 \mathrm{p}$.

Eakin, T. E., and Winograd, I. J., 1965, Interbasin movement of ground water in south-central Nevada - Some implications, in abstracts for 1964: Geol. Soc. America Spec. Paper 82, p. 52.

Ekren, E. B., 1968, Geologic setting of Nevada Test Site and Nellis Air Force Range, in Eckel, E. B., ed., Nevada Test Site: Geol. Soc. America Mem. 110, p. 11-20.

Ekren, E. B., Anderson, R. E., Rogers, C. L., and Noble, D. C., 1971, Geology of Northern Nellis Air Force Base Bombing and Gunnery Range, Nye County, Nevada: U.S. Geol. Survey Prof. Paper 651, $91 \mathrm{p}$.

Ekren, E. B., Rogers, C. L., Anderson, R. E., and Orkild, P. P., 1968, Age of basin and range normal faults in Nevada Test Site and Nellis Air Force Range, Nevada, in Eckel, E. B., ed., Nevada Test Site: Geol. Soc. America Mem. 110, p. 247-250.

Ekren, E. B., and Sargent, K. A., 1965, Geologic map of the Skull Mountain quadrangle, Nye County, Nevada: U.S. Geol. Survey Geol. Quad. Map GQ-387.

Fenneman, N. M., 1931, Physiography of Western United States: New York, McGraw-Hill Book Co., 534 p.

Ferris, J. G., 1959, Ground water, in Wisler, C. O., and Brater, E. F., eds., Hydrology [2d ed.]: New York, John Wiley \& Sons, chap. 6, p. 127-191.

Fleck, R. J., 1970, Tectonic style, magnitude, and age of deformation in the Sevier orogenic belt in southern Nevada and eastern California: Geol. Soc. America Bull., v. 81, no. 6, p. 1705-1720.

Garber, M. S., and Koopman, F. C., 1968, Methods of measuring water levels in deep wells: U.S. Geol. Survey Techniques WaterResources Inv., book 8, chap. A1, 23 p.

Garber, M. S., and Thordarson, William, 1962, Ground water test well C, Nevada Test Site, Nye County, Nevada: U.S. Geol. Survey TEI-818, open-file rept., $79 \mathrm{p}$.

Gibbons, A. B., Hinrichs, E. N., Hansen, W. R., and Lemke, R. W., 1963, Geology of the Rainier Mesa quadrangle, Nye County. Nevada: U.S. Geol. Survey Geol. Quad. Map GQ-215.

Grove, D. B., Rubin, Meyer, Hanshaw, B. B., and Beetem, W. A., 1969, Carbon-14 dates of ground water from a Paleozoic carbonate 
aquifer, south-central Nevada, in Geological Survey research 1969: U.S. Geol. Survey Prof. Paper 650-C, p. C215-C218.

Halliday, W. R., 1966, Depths of the earth: New York, Harper \& Row, $398 \mathrm{p}$.

Hamill, G. S., 1968, Structure and stratigraphy of the Mt. Shader quadrangle, Nevada-California, in Abstracts for 1966: Geol. Soc. America Spec. Paper 101, p. 399.

Hantush, M. S., 1964, Hydraulics of wells, in Chow, V. T., ed., Advances in hydroscience: New York, Academic Press, v. 1, p. 281-432.

Harrington, M. R., 1933, Gypsum Cave, Nev.: Los Angeles, Southwestern Mus. Paper 8, $197 \mathrm{p}$.

Harris, H. D., 1959, Late Mesozoic positive area in western Utah: Am. Assoc. Petroleum Geologists Bull., v. 43, no. 11, p. 2636-2652.

Haynes, C. V., Jr., 1965, Quaternary geology of the Tule Springs area, Clark County, Nevada: Arizona Univ. Ph. D. thesis.

Hem, J. D., 1959, Study and interpretation of the chemical characteristics of natural water: U.S. Geol. Survey Water-Supply Paper 1473, $269 \mathrm{p}$.

1961, Calculation and use of ion activity: U.S. Geol. Survey Water-Supply Paper $1535-\mathrm{C}, 17 \mathrm{p}$.

Hinrichs, E. N., 1968, Geologic structure of Yucca Flat area, Nevada, in Eckel, E. B., ed., Nevada Test Site: Geol. Snc. America Mem. 110 , p. $239-246$.

Hinrichs, E. N., and McKay, E. J., 1965, Geologic map of the Plutonium Valley quadrangle, Nye and Lincoln Counties, Nevada: U.S. Geol. Survey Geol. Quad. Map GQ-384.

Hood, J. W., 1961, Water wells in Frenchman and Yucca Valleys, Nevada Test Site, Nye County, Nevada: U.S. Geol. Survey TEI-788, open-file rept., $59 \mathrm{p}$.

Hoover, D. L., 1968, Genesis of zeolites, Nevada Test Site, in Eckel, E. B., ed., Nevada Test Site: Geol. Soc. America Mem. 110, p. 275-284.

Hubbs, C. L., and Miller, R. R., 1948, The zoological evidence Correlation between fish distribution and hydrographic history in the desert plains of western United States, in The Great Basin, with emphasis on glacial and postglacial times: Utah Univ. Bull., v. 38 , no. 20 , p. $18-166$.

Hughes, J. L., 1966, Some aspects of the hydrogeology of the Spring Mountains and Pahrump Valley, Nevada, and environs, as determined by spring evaluation: Reno, Nevada Univ. Masters thesis.

Hunt, C. B., and Mabey, D. R., 1966, Stratigraphy and structure, Death Valley, California: U.S. Geol. Survey Prof. Paper 494-A, $165 \mathrm{p}$.

Hunt, C. B., and Robinson, T. W., 1960, Possible interbasin circulation of ground water in the southern part of the Great Basin, in Short papers in the geological sciences: Geol. Survey Prof. Paper 400-B, p. B273-B274.

Hunt, C. B., Robinson, T. W., Bowles, W. A., and Washburn, A. L., 1966, Hydrologic basin, Death Valley, California: U.S. Geol. Survey Prof. Paper 494-B, 138 p.

Jacob, C. E., 1950, Flow of ground water, in Rouse, Hunter, ed., Engineering hydraulics: New York, John Wiley \& Sons, chap. 5, p. 321-386.

1963 , Determining the permeability of water-table aquifers, in Bentall, Ray, compiler, Methods of determining permeability, transmissibility, and drawdown: U.S. Geol. Survey Water-Supply Paper 1536-I, p. 245-271.

Jaeger, E. C., 1957, The North American deserts: Stanford Univ. Press, $308 \mathrm{p}$.

Jennings, C. W., 1958, Geologic map of California, Olaf P. Jenkins edition, Death Valley Sheet; California Div. Mines and Geology, scale $1: 250,000$.

Johnson, R. B., and Ege, J. R., 1964, Geology of the Pluto site, Area 401, Nevada Test Site, Nye County, Nevada: U.S. Geol. Survey TEI-841, open-file rept., $127 \mathrm{p}$.
Johnston, R. H., 1968, Exploratory drilling, tracer well construction and testing, and preliminary findings, pt. 1 of U.S. Geol. Survey tracer study, Amargosa Desert, Nye County, Nevada: U.S. Geol. Survey open-file rept., $64 \mathrm{p}$.

Lipman, P. W., 1965, Chemical comparison of glassy and crystalline volcanic rocks: U.S. Geol. Survey Bull. 1201-D, 24 p.

Lipman, P. W., and McKay, E. J., 1965, Geologic map of the Topopah Spring SW quadrangle, Nye County, Nevada: U.S. Geol. Survey Geol. Quad. Map GQ-439.

Loeltz, O. J., 1960, Source of water issuing from springs in Ash Meadow Valley, Nye County, Nevada [abs.]: Geol. Soc. America Bull., v. 71, no. 12 , pt. 2, p. 1917-1918.

Longwell, C. R., 1960, Possible explanation of diverse structural patterns in southern Nevada (Bradley volume): Am. Jour. Sci., v. 258-A, p. 192-203.

Longwell, C. R., Pampeyan, E. H., Boyer, Ben, and Roberts, R. J., 1965, Geology and mineral deposits of Clark County, Nevada: Nevada Bur. Mines Bull. 62, 218 p.

Loucks, T. L., and Guerrero, E. T., 1961, Pressure drop in a composite reservoir: Am. Inst. Mining Metall. Petroleum Engineers Trans., v. 222 , p. $170-176$.

Mabey, D. R., 1963, Complete Bouguer anomaly map of the Death Valley region, California: U.S. Geol. Survey Geophys. Inv. Map GP-305, scale 1:250,000.

Malmberg, G. T., 1961, A summary of the hydrology of the Las Vegas ground-water basin, Nevada, with special reference to the available supply: Nevada Water Resources Bull. 18, 23 p.

1965, Available water supply of the Las Vegas ground-water basin, Nevada: U.S. Geol. Survey Water-Supply Paper 1780, $116 \mathrm{p}$.

1967, Hydrology of the valley-fill and carbonate rock reservoirs, Pahrump Valley, Nevada-California: U.S. Geol. Survey Water-Supply Paper 1832, 47 p.

Malmberg, G. T., and Eakin, T. E., 1962, Ground-water appraisal of Sarcobatus Flat and Oasis Valley, Nye and Esmeralda Counties, Nevada: Nevada Dept. Conserv. and Nat. Resources, Ground-Water Resources - Reconn. Ser. Rept. 10, 39 p.

Maxey, G. B., and Jameson, C. H., 1948, Geology and water resources of Las Vegas, Pahrump, and Indian Springs Valleys, Clark and Nye Counties, Nevada: Nevada Water Resources Bull. 5, 121, p., app. 1, 128 p., app. 2, 43 p.

Maxey, G. B., and Mifflin, M. D., 1966, Occurrence and movement of ground water in carbonate rocks of Nevada, in Moore, G. W., ed., Limestone hydrology - a symposium with discussion: Natl. Speleol. Soc. Bull., v. 28 , no. 3, p. 141-157.

McJannett, G. S., and Clark, E. W., 1960, Drilling of the Meridian, Hayden Creek, and Summit Springs structure, in Boettcher, J. W., and Sloan, W. W., Jr., eds., Guidebook to the geology of eastcentral Nevada: Intermountain Assoc. Petroleum Geologists, 11th Ann. Field Conf., Salt Lake City, Utah Geol. and Mineralog. Survey, $264 \mathrm{p}$.

McKay, E. J., and Williams, W. P., 1964, Geology of the Jackass Flats quadrangle, Nye County, Nevada: U.S. Geol. Survey Geol. Quad. Map GQ-368.

McKeown, F. A., and Dickey, D. D., 1961, Interim report on geologic investigations of the U12e tunnel system, Nevada Test Site, Nye County, Nevada: U.S. Geol. Survey TEI-772, open-file rept., 17 p.

Mehringer, P. J., Jr., 1965, Late Pleistocene vegetation in the Mohave Desert of southern Nevada: Arizona Acad. Sci. Jour. v. 3, no. 3, p. $172-188$.

Meinzer, O. E., 1923, Outline of ground-water hydrology, with definitions: U.S. Geol. Survey Water-Supply Paper 494, 71 p.

Meyers, J. S., 1962, Evaporation from the 17 Western States, with a section on Evaporation rates, by T. J. Nordenson: U.S. Geol. Survey Prof. Paper 272-D, p. 71-100. 
Miller, R. R., 1946, Correlation between fish distribution and Pleistocene hydrography in eastern California and southwestern Nevada, with a map of the Pleistocene waters: Jour. Geology, v. 54 , no. 1 , p. $43-53$.

1948, The Cyprinodont fishes of the Death Valley system of eastern California and southwestern Nevada: Michigan Univ. Mus. Zoology Misc. Pub. 68.

Moore, G. W., 1960, Origin of limestone caves - a symposium with discussion: Natl. Speleol. Soc. Bull., v. 22, pt. 1, p. 3-84.

ed., 1966a, Limestone hydrology - a symposium with discussion: Natl. Speleol. Bull., v. 28, no. 3, p. 109-166.

1966b, Introduction to limestone hydrology, in Moore, G. W., ed., Limestone hydrology - a symposium with discussion: Natl. Speleol. Soc. Bull., v. 28, no. 3, p. 109-110.

Moore, J. E., 1961, Records of wells, test holes, and springs in the Nevada Test Site and surrounding area: U.S. Geol. Survey TEI-781, open-file rept., $22 \mathrm{p}$.

1962, Selected logs and drilling records of wells and test holes drilled at the Nevada Test Site prior to 1960: U.S. Geol. Survey TEI-804, open-file rept., 54 p.

Moore, J. E., Doyle, A. C., Walker, G. E., and Young, R. A., 1963, Ground-water test well 2, Nevada Test Site, Nye County, Nevada: U.S. Geol. Survey TEI-836, open-file rept. 73 p.

Moore, J. E., and Garber, M. S., 1962, Ground-water test well B, Nevada Test Site, Nye County, Nevada: U.S. Geol. Survey TEI-808, open-file rept., 39 p.

Muskat, Morris, 1937, The flow of homogeneous fluids through porous media: New York, McGraw-Hill Book Co., 763 p.

Nevada Chamber of Commerce, 1965, Las Vegas Report, A compendium of statistical, commercial, and social facets of Las Vegas for year 1964: Las Vegas.

Nisle, R. G., 1958, The effect of partial penetration on pressure buildup in oil wells: Am. Inst. Mining Metall. Petroleum Engineers Trans., v. 213, p. $85-90$.

Noble, D. C., 1968, Kane Springs Wash volcanic center, Lincoln County, Nevada, in Eckel, E. B., ed., Nevada Test Site: Geol. Soc. America Mem. 110, p. 109-116.

Noble, D. C., Sargent, K. A., Mehnert, H. H., Ekren, E. B., and Byers, F. M., Jr., 1968, Silent Canyon volcanic center, Nye County, Nevada, in Eckel, E. B., ed., Nevada Test Site: Geol. Soc. America Mem. 110, p. 65-75.

Nolan, T. B., 1962, The Eureka Mining district, Nevada: U.S. Geol. Survey Prof. Paper 406, 78 p.

Orkild, P. P., 1963, Geologic map of the Tippipah Spring quadrangle, Nye County, Nevada: U.S. Geol. Survey Geol. Quad. Map GQ-213.

1965, Paintbrush Tuff and Timber Mountain Tuff of Nye County, Nevada, in Cohee, G. V., and West, W. S., Changes in stratigraphic nomenclature by the U.S. Geological Survey, 1964: U.S. Geol. Survey Bull. 1224-A, p. A44-A51.

1968, Geologic map of the Mine Mountain quadrangle, Nye County, Nevada: U.S. Geol. Survey Geol. Quad. Map GQ-746.

Orkild, P. P., Byers, F. M., Jr., Hoover, D. L., and Sargent, K. A., 1968, Subsurface geology of Silent Canyon caldera, Nevada Test Site, Nevada, in Eckel, E. B., ed., Nevada Test Site: Geol. Soc. American Mem. 110, p. 77-86.

Parsons, R. W., 1966, Permeability of idealized fractured rock: Soc. Petroleum Engineers Jour., v. 6, no. 2, p. 126-136.

Piper, A. M., 1944, A graphic procedure in the geochemical interpretation of water analyses: Am. Geophys. Union Trans. of 1944, 25th Ann. Mtg., Pt. 6, p. 914-923, discussion p. 924-928.

Pistrang, M. A., and Kunkel, Fred, 1964, A brief geologic and hydrologic reconnaissance of the Furnace Creek Wash area, Death Valley National Monument, California: U.S. Geol. Survey WaterSupply Paper 1779-Y, 35 p.
Poole, F. G., 1965, Geologic map of the Frenchman Flat quadrangle, Nye, Lincoln, and Clark Counties, Nevada: U.S. Geol. Survey Geol. Quad. Map GQ-456.

Poole, F. G., Carr, W. J., and Elston, D. P., 1965, Salyer and Wahmonie Formations of southeastern Nye County, Nevada, in Cohee, G. V., and West, W. S., Changes in stratigraphic nomenclature by the U.S. Geological Survey, 1964: U.S. Geol. Survey Bull. 1224-A, p. A36-A44.

Poole, F. G., Elston, D. P., and Carr, W. J., 1965, Geologic map of the Cane Springs quadrangle, Nye County, Nevada: U.S. Geol. Survey Geol. Quad. Map GQ-455.

Poole, F. G., Houser, F. N., and Orkild, P. P., 1961, Eleana Formation of the Nevada Test Site and vicinity, Nye County, Nevada, in Short papers in the geologic and hydrologic sciences: U.S. Geol. Survey Prof. Paper 424-D, p. D104-D111.

Price, C. E., and Thordarson, William, 1961, Ground-water test well A, Nevada Test Site, Nye County, Nevada, a summary of lithologic data, aquifer tests, and construction: U.S. Geol. Survey TEI-800, open-file rept., $59 \mathrm{p}$.

Quiring, R. F., 1965, Annual precipitation amount as a function of elevation in Nevada south of $381 / 2$ degrees latitude: Las Vegas, Nev., U.S. Weather Bur. Research Sta., 14 p.

Ross, C. S., and Smith, R. L., 1961, Ash-flow tuffs - Their origin, geologic relations, and identification: U.S. Geol. Survey Prof. Paper 366, 81 p.

Ross, R. J., Jr., and Longwell, C. R., 1964, Paleotectonic significance of Ordovician sections south of the Las Vegas shear zone, in Ross, R. J., Jr., Middle and Lower Ordovician formations in southernmost Nevada and adjacent California: U.S. Geol. Survey Bull. 1180-C, p. C88-C93.

Schoff, S. L., and Moore, J. E., 1964, Chemistry and movement of ground water, Nevada Test Site: U.S. Geol. Survey TEI-838, open-file rept., $75 \mathrm{p}$.

Schoff, S. L., and Winograd, I. J., 1961, Hydrologic significance of six core holes in carbonate rocks of the Nevada Test Site: U.S. Geol. Survey TEI-787, open-file-rept. $97 \mathrm{p}$.

1962, Potential aquifers in carbonate rocks, Nevada Test Site, Nevada, in Short papers in geology and hydrology: U.S. Geol. Survey Prof. Paper 450-C, art. 105, p. C111-C113.

Seaber, P. R., 1965, Variations in chemical character of water in the Englishtown Formation, New Jersey: U.S. Geol. Survey Prof. Paper 498-B, $35 \mathrm{p}$.

Secor, D. T., Jr., 1962, Geology of the central Spring Mountains, Nevada: Stanford University Ph. D. thesis.

Smith, R. L., 1960, Zones and zonal variations in welded ash flows: U.S. Geol. Survey Prof. Paper 354-F, p. F149-F159.

Stallman, R. W., 1965, Effects of water table conditions on water level changes near pumping wells: Water Resources Research, v. 1, no. 2, p. 295-312.

Stewart, J. H., 1967, Possible large right-lateral displacement along fault and shear zones in the Death Valley-Las Vegas area, California and Nevada: Geol. Soc. America Bull., v. 78, no. 2, p. 131-142.

Stuart, W. T., 1955, Pumping test evaluates water problem at Eureka, Nevada: Am Inst. Mining Metall. Petroleum Engineers Trans., v. 202, p. $148-156$.

Thordarson, William, 1965, Perched ground water in zeolitized-bedded tuff, Rainier Mesa and vicinity, Nevada Test Site: U.S. Geol. survey TEI-862, open-file rept., $90 \mathrm{p}$.

Thordarson, William, Garber, M. S., and Walker, G. E., 1962, Groundwater test well D, Nevada Test Site, Nye County, Nevada: U.S. Geol. Survey TEI-803, open-file rept., $58 \mathrm{p}$.

Thordarson, William, Young, R. A., and Winograd, I. J., 1967, Records of wells and test holes in the Nevada Test Site and vicinity (through December 1966): U.S. Geol Survey TEI-872, open-file rept., $26 \mathrm{p}$. 
Tóth, J., 1963, A theoretical analysis of ground-water flow in small drainage basins: Jour. Geophys. Research, v. 68, no. 16, p. 4795-4812.

Tschanz, C. M., and Pampeyan, E. H., 1961, Preliminary geologic map of Lincoln County, Nevada: U.S. Geol. Survey Mineral Inv. Field Studies Map MF-206.

Vincelette, R. R., 1964, Structural geology of the Mt. Stirling quadrangle, Nevada, and related scale-model experiments: Stanford University $\mathrm{Ph}$. D. thesis.

Walker, G. E., 1962, Ground water in the Climax stock, Nevada Test Site, Nye County, Nevada: U.S. Geol. Survey TEI-813, open-file rept., $48 \mathrm{p}$.

Walker, G. E., and Eakin, T. E., 1963, Geology and ground water of Amargosa Desert, Nevada-California: Nevada Dept. Conserv. and Nat. Resources, Ground-Water Resources - Reconn. Ser. Rept. $14,45 \mathrm{p}$.

Walton, W. C., 1962, Selected analytical methods for well and aquifer evaluation: Illinois State Water Survey Bull. 49, 81 p.

Warren, J. E., and Price, H. S., 1961, Flow in heterogeneous porous media: Am. Inst. Mining Metall. Petroleum Engineers Trans., v. 222 , p. $153-169$.

Weedfall, R. O., 1963, An approach to the development of isohyetal maps for the Nevada and California deserts: Las Vegas, Nev., U.S. Weather Bur. Research Sta., 17 p.

Wells, P. V., and Jorgensen, C. D., 1964, Pleistocene wood rat middens and climatic change in Mohave Desert: A record of juniper woodlands: Sci., v. 143 , no. 3611 , p. 1171-1174.

White, W. B., 1960, Terminations of passages in Appalachian caves as evidence for a shallow phreatic origin, in Moore, G. W., ed., Origin of limestone caves - a symposium with discussion: Natl. Speleol. Soc. Bull., v. 22, pt. 1, p. 43-53.

Winograd, I. J., 1962, Interbasin movement of ground water at the
Nevada Test Site, Nevada, in Short papers in geology and hydrology: U.S. Geol. Survey Prof. Paper 450-C, p. C108-C111.

1963, A summary of the ground-water hydrology of the area between the Las Vegas Valley and the Amargosa Desert, Nevada, with special reference to the effects of possible new withdrawals of ground water, in U.S. Congress, Nevada Test Site Community, hearings before Joint Committee on Atomic Energy: U.S. 88th Cong., 1st sess., Sept. and Oct. 1963, p. 197-226 (also U.S. Geol. Survey TEI-840, open-file rept., 79 p.).

1970, Noninstrumental factors affecting measurement of static water level in deeply buried aquifers and aquitards, Nevada Test Site: Ground Water, v. 8, no. 2, p. 19-28.

Winograd, I. J., and Eakin, T. E., 1965, Interbasin movement of ground water in south-central Nevada - The evidence, in Abstracts for 1964: Geol. Soc. America Spec. Paper 82, p. 227.

Winograd, I. J., and Friedman, I., 1969, Delineation of regional ground-water flow systems using deuterium, eastern Great Basin, Nevada: Geol. Soc. America, Abstracts with Programs for 1969, pt. 7 , p. $239-240$.

1972, Deuterium as a tracer of regional ground-water flow, southern Great Basin, Nevada-California: Geol Soc. America Bull., v. 83, no. 12 , p. $3691-3708$.

Winograd, I. J., and Thordarson, William, 1968, Structural control of ground-water movement in miogeosynclinal rocks of south-central Nevada, in Eckel, E. B., ed., Nevada Test Site: Geol. Soc. America Mem. 110, p. 35-48.

Worts, G. F., Jr., 1963, Effect of ground-water development on the pool level in Devils Hole, Death Valley National Monument, Nye County, Nevada: U.S. Geol. Survey open-file rept., 27 p.

Young, R. A., 1972, Water-supply for Nuclear Rocket Development Station at the Atomic Energy Commission's Nevada Test Site: U.S. Geol. Survey Water-Supply Paper 1938, 19 p. 



\section{INDEX}

[Page numbers of major references are in italic]

A

Alkali Flat, ground-water chemistry _._. _ C99 Alluvial-fan deposits. See Valley-fill aquifer.

Alluvium, Quaternary _. Amargosa Desert _....... $4,13,14,19,20,37$ ground-water chemistry ___ ground-water movement _. _ _ _ _ _ 111 potentiometric trough _... underflow Amargosa River _............... 4 Ammonia Tanks Member of Timber Mountain Tuff _31 Aquifers _. _ bedded tuff distribution _... lower carbonate ground-water velocity _._. transmissibility potentiometric map _... saturation _. upper carbonate valley-fill _. ground-water age welded-tuff _... Aquitards _ Climax stock _. Gold Meadows stock _ _ _ ground-water movement control _._. Horse Spring Formation hydraulic tests _. lower clastic Pavits Spring Rocks _._. transmissibility tuff _... ground-water age ground-water movement _... ground-water velocity upper clastic _. Ash-flow tuff. See Welded tuff.

Ash Meadows _. ground-water basin _. ground-water chemistry _. _ _ _ _ _ 104 ground-water movement _._._. potentiometric trough _._. underflow _ _ _

Ash Meadows-Amargosa Desert discharge area _. Aztec Sandstone _.

Banded Mountain _______________ 15 Basalt. See Lava-flow aquifer.

Basin and Range, topography _..._. _ _ 9,13

Beatty, Nev. -

Bedded-tuff aquifer

Belt Range

Bibliography _.

Big Spring _.

Bird Spring Formation

Bonanza King Formation ground-water chemistry _

Breccia zones, transmissibility _...

Brecciation -

C

CP Basin _. CP thrust fault, ground-water control _._. Calico Hills _._. _ _ _ _ _ _ _ _ _ 106 Calico Hills beds
Cane Spring fault zone Cane Springs _._. Carbonate aquifers, lower _... ground-water velocity transmissibility _.

upper -

Carrara Formation _... 13, 28, 39

Caverns _.

Caves _.

Chainman Shale, ground-water _.

Chemistry, facies

ground-water

Chinle Formation _.

Clark County, Nev. _._.

Clastic aquitard, upper

Clebsch, Alfred, Jr. _-

Climate _.

Climax stock aquitard _.

Cold Creek Spring _._._-

Columnar jointing _.

Cooling units _.

Cordilleran geosyncline

Core samples _

Crater Flat

Crater Flat Tuff _...

ground-water chemistry

Crystal Pool

D

Davis, R. E.

Death Valley

Desert Range _...

Desert Valley ground-water chemistry _-__ground-water movement

Devils Hole _.

Discharge, springs _.....

Dissolved solids, lower carbonate aquifer

Drill-stem tests

Dunderberg Shale Member of Nopah Formation 9, 40, 42 ground-water chemistry _._. 102

E

Eleana Formation

Emerick, W. L.

Emigrant Valley _. ground-water chemistry _._. ground-water movement _...

Eureka mining district _

Eureka Quartzite

Evapotranspiration estimates _.

\section{F}

Fairbanks Spring

Fanglomerate deposits. See Valley-fill aquifer.

Faulting _. springs control _._.

transmissibility _...

Flowmeter surveys _.

Fluvial deposits. See Valley-fill aquifer.

Folding _.

Foliation _.

Fortymile Canyon-Oasis Valley ground-water basin -94

Fracturing _. filling _. porosity _. transmissibility
Page

Frenchman Flat _..._._C2, 4, 9, 11, 12, 37, 97 ground-water chemistry ___ _ _ _ _ _ 104 ground-water movement potentimetric trough springs _... tuff aquitard _._.

Funeral Mountains _.

Furnace Creek Wash-Nevares Springs discharge area 95 ground-water chemistry ____ ground-water movement _._. spring discharge

Geomorphology Geosyncline Gold Meadows stock aquitard Groom Range _._.

Ground water, chemistry _._. contamination _. movement _._.

Ash Meadows _. 108

Frenchman Flat _........

lower carbonate aquifer

Pahrump Valley _.

regional summary _.

Stewart Valley _.

velocity _-

Yucca Flat

perched ..... Grouse Canyon Member of Indian Trail Formation -34 Gypsum Cave

$\mathrm{H}$

Halfpint Range anticline Historical geology _. Horse Spring Formation aquitard _. Hydraulic tests, lower clastic aquitard tuff aquitard _. upper clastic aquitard _............ welded-tuff aquifer Hydrochemical facies

Indian Springs _Indian Springs Valley ground-water chemistry _.......... 98, 104, 109 ground-water movement _ _ _ _ _ Indian Trail Formation Grouse Canyon Member

Tub Spring Member _. Inyo County, Calif. _. Irrigation Isohyetal map _

\section{J, K}

Jackass Flats _... aquitard _...

springs _.

Joana Limestone, ground water Johnnie Formation ground-water chemistry _... 102 Joints _

Kiwi Mesa Basalt $-36$ 
Page

L

Lake Mead, water source _._._._._._._. C6 Lakebed deposits. See Valley-fill aquifer

Las Vegas _._.

Las Vegas ground-water basin _._.

Las Vegas Valley _. ground-water chemistry _._.___. 98,109 shear zone Lathrop Wells _._. Lava-flow aquifer

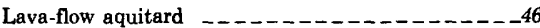

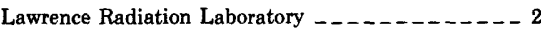

Leakage, computation _... recharge _.

Yucca Flat Lincoln County, Nev. . Lithology _. . . . . Lone Mountain Dolomite, ground water _._-___ 103 Los Alamos Scientific Laboratory - Lower carbonate aquifer _. ground-water chemistry _._. ground-water movement _._. ground-water velocity _._._____ 113 potentiometric map _... storage coefficient _. transmissibility . . . .

Lower clastic aquitard

M

Mercury, Nev. _.. Mercury Valley _._..._._. ground-water chemistry _._._____ 102 ground-water movement Miogeosynclinal sedimentation _._._______ 9 Monte Cristo Limestone _._.

Montgomery thrust fault _._._______ 75,91 Movement, ground-water _.........

$\mathrm{N}, \mathrm{O}$

National Aeronautics and Space Administration _..- 6 Nellis Air Force Base Nevada Formation, ground water Nevares Springs-Furnace Creek Wash discharge area 95 ground-water chemistry _-___-__ground-water movement _._. spring discharge _....

Ninemile Formation _......._.

Noonday Dolomite _ground-water chemistry Nopah Formation _. Dunderberg Shale Member _.______ 9, 40, 42 ground-water chemistry _- 102

Nuclear testing, ban - _. underground - .

Nye County, Nev. _.

Oasis Valley, ground-water chemistry _ _._______98 Oasis Valley-Fortymile Canyon ground-water basin 1, 94 Orogeny _ . _ _ _ _

Pahranagat Range _. Pahranagat Valley _... ground-water chemistry _._. ground-water movement _._. 110

Pahrump Valley _._..._. ground-water basin ground-water chemistry _._. ground-water movement _._.

Pahute Mesa _... ground-water chemistry _._. Paintbrush Tuff _._.

Pavits Spring _...
Pavits Spring Rocks _.____________C43, 105 aquitard _. ground-water chemistry

Perched ground water -

Permeability - ground water movement control _._._._. 113

Physiography _.... . Piapi Canyon Group _..._._._._._. 31, 36

Pintwater Range anticline _._.

Pluvial periods _._.

Point of Rocks Springs _ _ _

Population centers _._-

Porosity _aquitards clastic rocks _.. lower carbonate aquifer _.

Potentiometric map _.. lower carbonate aquifer - _

Precipitation _. recharge -

Pumping tests _.

\section{$\mathbf{R}$}

Rainier Mesa _._. Rainier Mesa Member of Timber Mountain Tuff 31, 34

Ramming effect _. Ranger Mountains _. Recharge _.

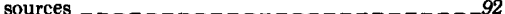

Resting Springs Range ......

Reynoids Electrical and Engineering Co. ........ 3 Rhyolite. See Lava-flow aquifer.

Rock Valley _. ground-water chemistry _._. lower carbonate aquifer

\section{$\mathrm{s}$}

Salyer Formation _. ground-water chemistry _.

Sevier Arch _. . _ _ _

Sheep Range springs _.

Shoshone Mountain Rhyolite _....._._._-_36

Silent Canyon caldera, ground water _._._._._. 94

Skull Mountain Basalt _.

Snyder, R. P.

Sodium, lower carbonate aquifer _._. _ _ 103 Specter Range, ground-water velocity _... potentiometric trough _._.

Specter Range thrust _.

Spotted Range _.

Spring Mountains _. caves _._. ground-water chemistry _. springs __________ 50,52 Spring Valley Springs _. Big Spring _ _ _ Crystal Pool _. _. _ _ _ _ _ _ _ _ _ _ 81 discharge _._. Fairbanks Spring _._. Point of Rocks Springs _._____ 79 Spotted Range syncline _.

Stewart Valley _. fault zone _... ground-water movement Stirling Quartzite _._._._.___ 39,82 Stratigraphy _._. Structural geology _._. ground-water basin boundaries _._._. ground-water control _. Stylolites - -

Sulfate, lower carbonate aquifer
Temperature gradients, Ash Meadows discharge area $\mathrm{C} 80$ Test drilling, Yucca Flat - . Texas Spring _.

Three Lakes Valley _.................. 4 ground-water chemistry _... ground-water movement _._.______ 62,67

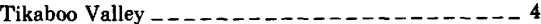

Timber Mountain caldera, ground-water control _ _ -94 Timber Mountain Tuff _._. Timpahute Range Tippinip thrust fault joints _. Tiva Canyon Member of Paintbrush Tuff ... 31, 34 Topopah Spring Member of Paintbrush Tuff -- 31, 34 Transmissibility _._. _ _ _ _ _ _ _ 34,117 aquitards _. coefficients _. faulting _._. fracturing - . lava-flow aquitard _........ lithologic control _... lower carbonate aquifer . . structural control _. tuff aquitard _....... valley-fill aquifer _.

Travertine Springs Tub Spring Member of Indian Trail Formation ____-34 Tuff aquitard _... ground-water age _... ground-water movement _._. _._._._._._. 109 ground-water velocity

$\mathrm{U}, \mathrm{v}$

Underflow _.. recharge United States Atomic Energy Commission _...-1, 2 Upper carbonate aquifer, saturation zone Upper clastic aquitard

Valley-fill aquifer _._._._._._._. 14, 37, 118 age of ground-water _. Vegetation _..._Volcanics _. Volcanism, Miocene _._.

Wahmonie Flat -

Wahmonie Formation _..._........ 12, 36, 43 ground-water chemistry -

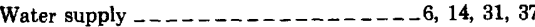

Welded-tuff aquifer - . Well-numbering system _..._. White Pine County, ground water _._._._._. 103 Whiterock Springs _. _.

Williams, $\dot{W}$. P. _ _

Willow Spring -

Wood Canyon Formation _.

Worthington Mountain, caves _..._.

Y, Z

Yucca Flat _._._ 2, 4, 6, 9, 11, 12, 19, 20, 30, 47, 97 aquitard _. Climax aquitard _... Gold Meadows aquitard _._. ground-water chemistry _._. ground-water movement _.

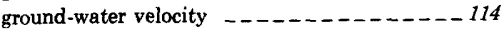
joints _._. leakage _. lower carbonate aquifer potentimetric trough _._._. springs _. test drilling - . . tuff aquitard _.

Zabriskie Quartzite ... 

